\title{
Redondo Beach, California, 1992-1994 Wave Data
}

by Margaret $A$. Sabol 
The contents of this report are not to be used for advertising, publication, or promotional purposes. Citation of trade names does not constitute an official endorsement or approval of the use of such commercial products. 


\section{Redondo Beach, California, 1992-1994 Wave Data}

by Margaret A. Sabol

U.S. Army Corps of Engineers

Waterways Experiment Station

3909 Halls Ferry Road

Vicksburg, MS 39180-6199

Final report

Approved for public release; distribution is unlimited 


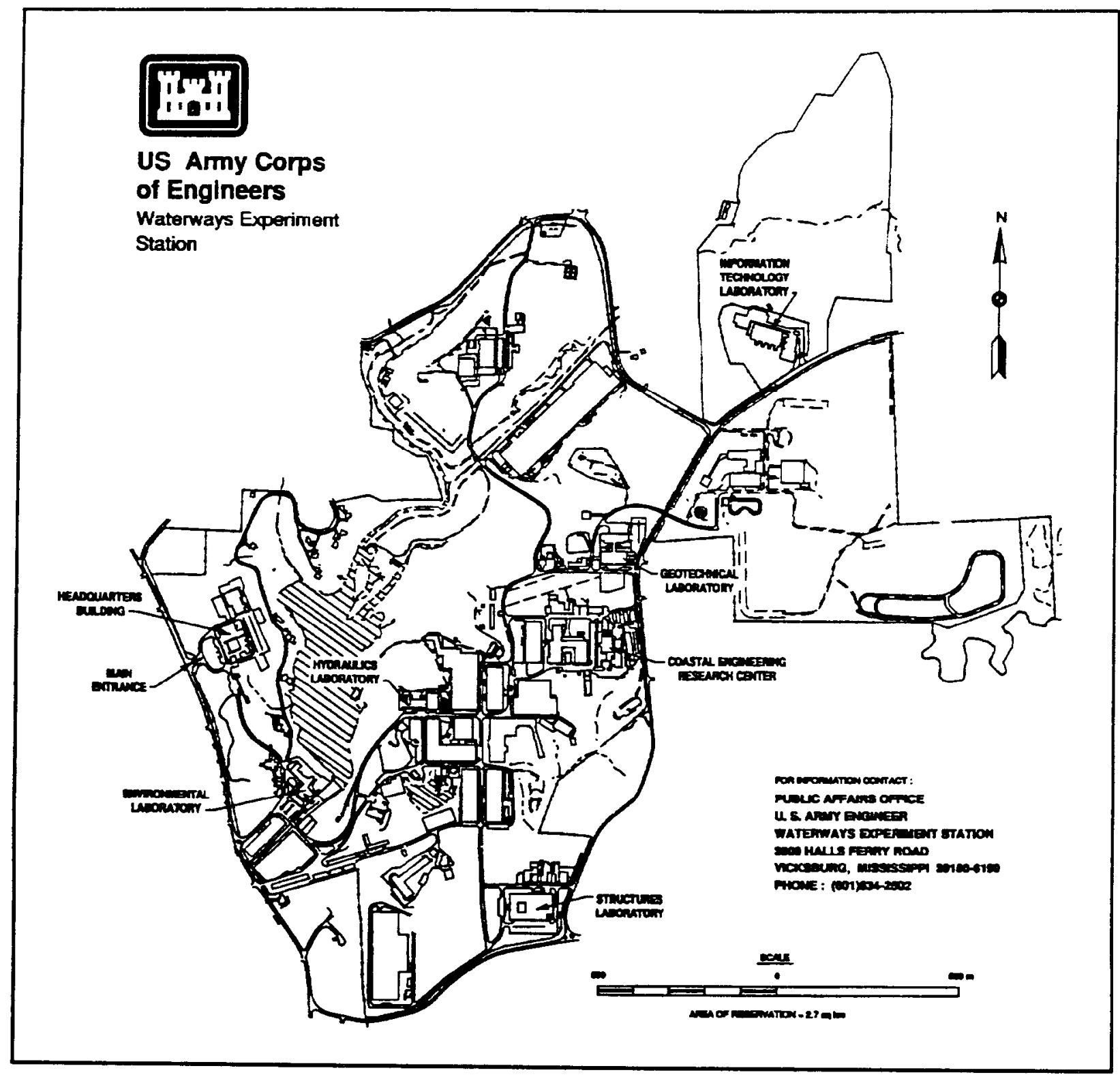

\section{Waterways Experiment Station Cataloging-in-Publication Data}

Sabol, Margaret A.

Redondo Beach, California, 1992-1994 wave data / by Margaret A.

Sabol ; prepared for U.S. Army Corps of Engineers.

140 p. : ill. ; $28 \mathrm{~cm}$. - (Technical report ; CERC-96-4)

1. Ocean waves - Measurements. 2. RCPWAVE (Computer program) 3. Breakwaters - California - Redondo Beach. 4. Redondo Beach (Calif.) I. United States. Army. Corps of Engineers. II. U.S. Army Engineer Waterways Experiment Station. III. Coastal Engineering Research Center (U.S. Army Engineer Waterways Experiment Station) IV. Title. V. Series: Technical report (U.S. Army Engineer Waterways Experiment Station); CERC-96-4.

TA7 W34 no.CERC-96-4 


\section{Contents}

Preface $\ldots \ldots \ldots \ldots \ldots \ldots \ldots \ldots \ldots \ldots \ldots \ldots \ldots \ldots$

1 -Introduction $\ldots \ldots \ldots \ldots \ldots \ldots \ldots \ldots \ldots \ldots \ldots \ldots \ldots$

Background $\ldots \ldots \ldots \ldots \ldots \ldots \ldots \ldots \ldots \ldots \ldots \ldots \ldots \ldots \ldots$

Nearshore Wave Conditions $\ldots \ldots \ldots \ldots \ldots \ldots \ldots \ldots \ldots$

Offshore Wave Conditions $\ldots \ldots \ldots \ldots \ldots \ldots \ldots \ldots$

2-Nearshore Wave Conditions .................. 5

Nearshore Gage Description .................... 5

Gage Deployment ...................... 5

3-Data Summary Products $\ldots \ldots \ldots \ldots \ldots \ldots \ldots \ldots \ldots$

Description of Parameters $\ldots \ldots \ldots \ldots \ldots \ldots \ldots \ldots \ldots$

Description of Products $\ldots \ldots \ldots \ldots \ldots \ldots \ldots \ldots \ldots \ldots \ldots$

Time Series Plots $\ldots \ldots \ldots \ldots \ldots \ldots \ldots \ldots \ldots \ldots$

Mean/Max Tables ....................... 8

Percent Occurrence Tables . . . . . . . . . . . . . . . . . 9

Wave Rose Diagrams $\ldots \ldots \ldots \ldots \ldots \ldots \ldots \ldots \ldots \ldots \ldots$

Spectral Density Plots $\ldots \ldots \ldots \ldots \ldots \ldots \ldots \ldots \ldots \ldots \ldots \ldots$

Appendix A: North Site, First Deployment $\ldots \ldots \ldots \ldots \ldots \ldots$ A1

Appendix B: North Breakwater Site, First Deployment ......... B1

Appendix C: Near Breakwater Site, First Deployment ......... C1

Appendix D: Suuth Breakwater Site, First Deployment ......... D1

Appendix E: Canyon Site, First Deployment $\ldots \ldots \ldots \ldots \ldots \ldots \ldots$ E1

Appendix F: Redondo Site, First Deployment $\ldots \ldots \ldots \ldots \ldots \ldots \ldots$ F1

Appendix G: Catalina Ridge Site, First Deployment ........... G1

Appendix H: North Breakwater Site, Second Deployment ......... H1

Appendix I: South Breakwater Site, Second Deployment .......... I1

Appendix J: Redondo Site, Second Deployment ............ J1

Appendix K: Catalina Ridge Site, Second Deployment .......... K1 
Appendix L: Additional NDBC Time Series Plots $\ldots \ldots \ldots \ldots \ldots \ldots$ L1 SF 298 


\section{Preface}

This report is a product of the Redondo Beach, CA, Work Unit of the Monitoring Completed Coastal Projects (MCCP) Program, prepared by the Coastal Engineering Research Center (CERC), U.S. Army Engineer Waterways Experiment Station (WES). The MCCP Program Manager is Ms. Carolyn M. Holmes. Technical monitors of the MCCP Program at Headquarters, U.S. Army Corps of Engineers, are Mr. John H. Lockhart, Jr., Mr. Charles Chesnutt, and Mr. Barry W. Holliday. Dr. Thomas E. White, Prototype Measurement and Analysis Branch (PMAB), Engineering Development Division (EDD), CERC, was the former Principal Investigator and Dr. Joon P. Rhee, PMAB, EDD, CERC is the current Principal Investigator.

This report was prepared by Ms. Margaret A. Sabol, PMAB, under the general supervision of Mr. William L. Preslan, Chief, PMAB, and Mr. Thomas W. Richardson, Chief, EDD. Mr. Charles C. Calhoun, Jr. and Dr. James R. Houston are Assistant Director and Director, respectively, of CERC. Director of WES is Dr. Robert W. Whalin, and Commander is COL Bruce K. Howard, EN.

The contents of this report are not to be used for advertising, publication, or promotional purpases. Citation of trade names does not constitute an official endorsement or approval of the use of such commercial products. 


\section{Introduction}

\section{Background}

Field wave data were acquired at Redondo Beach Breakwater, CA, by the Prototype Measurement and Analysis Branch of the U.S. Army Engineer Waterways Experiment Station Coastal Engineering Research Center as part of the Monitoring Completed Coastal Projects Program. This repon summarizes data collected throughout the experiment. The purpose of this study was to provide actual field data to evaluate output from a numerical model, Regional Coastal Processes Wave Transformation Model, which predicts waves propagating through a coastal region of irregular bathymetry. This report contains brief descriptions of the monitoring effort and equipment and provides collected wave information in graphic and tabular form. Statistical analysis of wave data will be provided in a future report.

\section{Nearshore Wave Conditions}

Nearshore and offshore wave conditions at Redondo Beach, CA, were monitored during a 2-year period beginning October 1992 and ending in June 1994. Nearshore gages were deployed at two separate times during the monitoring period in depths of $14 \mathrm{~m}-18 \mathrm{~m}$. The first gages were deployed October 1992 through April 1993 and the second deployment was from October 1993 through June 1994.

\section{Offshore Wave Conditions}

Offshore wave conditions were collected from two National Data Buoy Center (NDBC) directional wave buoys. Conditions of waves in intermediatedepth water were provided by NDBC buoy 46045 (Redondo) located in approximately $80 \mathrm{~m}$ of water. Deepwater wave data were obtained from NDBC buoy 46025 (Catalina Ridge) at a nominal water depth of $840 \mathrm{~m}$. Locations of the shallow-water gages and NDBC buoys are shown in Table 1 and in Figures 1 and 2. 


\begin{tabular}{||l|l|l||}
\hline \multicolumn{2}{|l|}{$\begin{array}{l}\text { Table 1 } \\
\text { Gage Information }\end{array}$} \\
\hline \hline $\begin{array}{l}\text { Gage } \\
\text { Number }\end{array}$ & Site Designation & Location \\
\hline \hline RB6 & North & 33.860 N $118.412 \mathrm{~W}$ \\
\hline 020 & North Breakwater & 33.848 N $118.406 \mathrm{~W}$ \\
\hline 153 & South Breakwater (PUV) & 33.843 N $118.404 \mathrm{~W}$ \\
\hline RB4A & South Breakwater (DWG-1) & 33.842 N $118.404 \mathrm{~W}$ \\
\hline RB5 & Canyon & $33.830 \mathrm{~N} 118.399 \mathrm{~W}$ \\
\hline 030 & Near Breakwater & $33.846 \mathrm{~N} 118.401 \mathrm{~W}$ \\
\hline 46045 & Redondo & $33.839 \mathrm{~N} 118.447 \mathrm{~W}$ \\
\hline 46025 & Catalina Ridge & $33.747 \mathrm{~N} 119.068 \mathrm{~W}$ \\
\hline
\end{tabular}




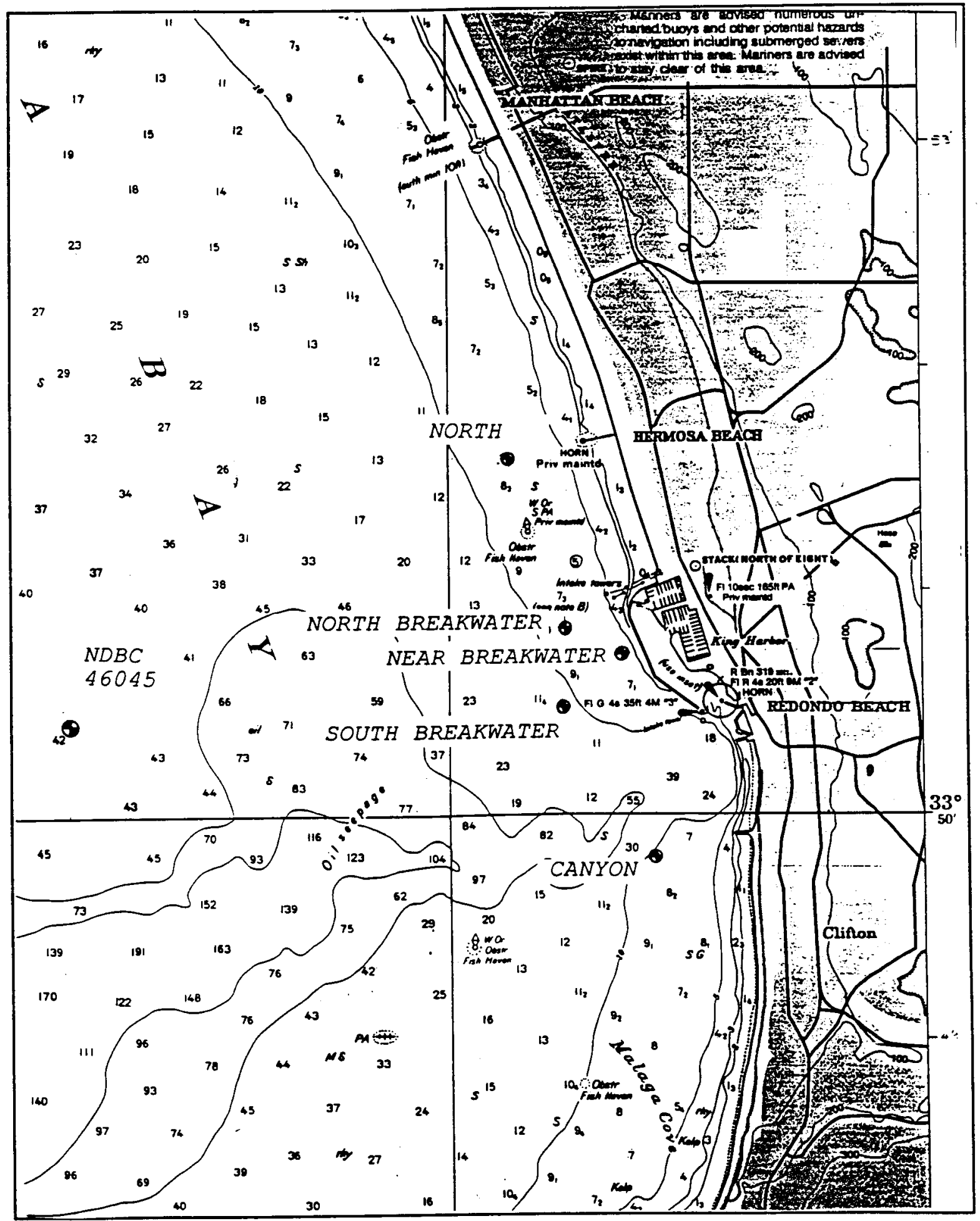

Figure 1. Location of shallow and intermediate-depth gages (soundings in fathoms) 


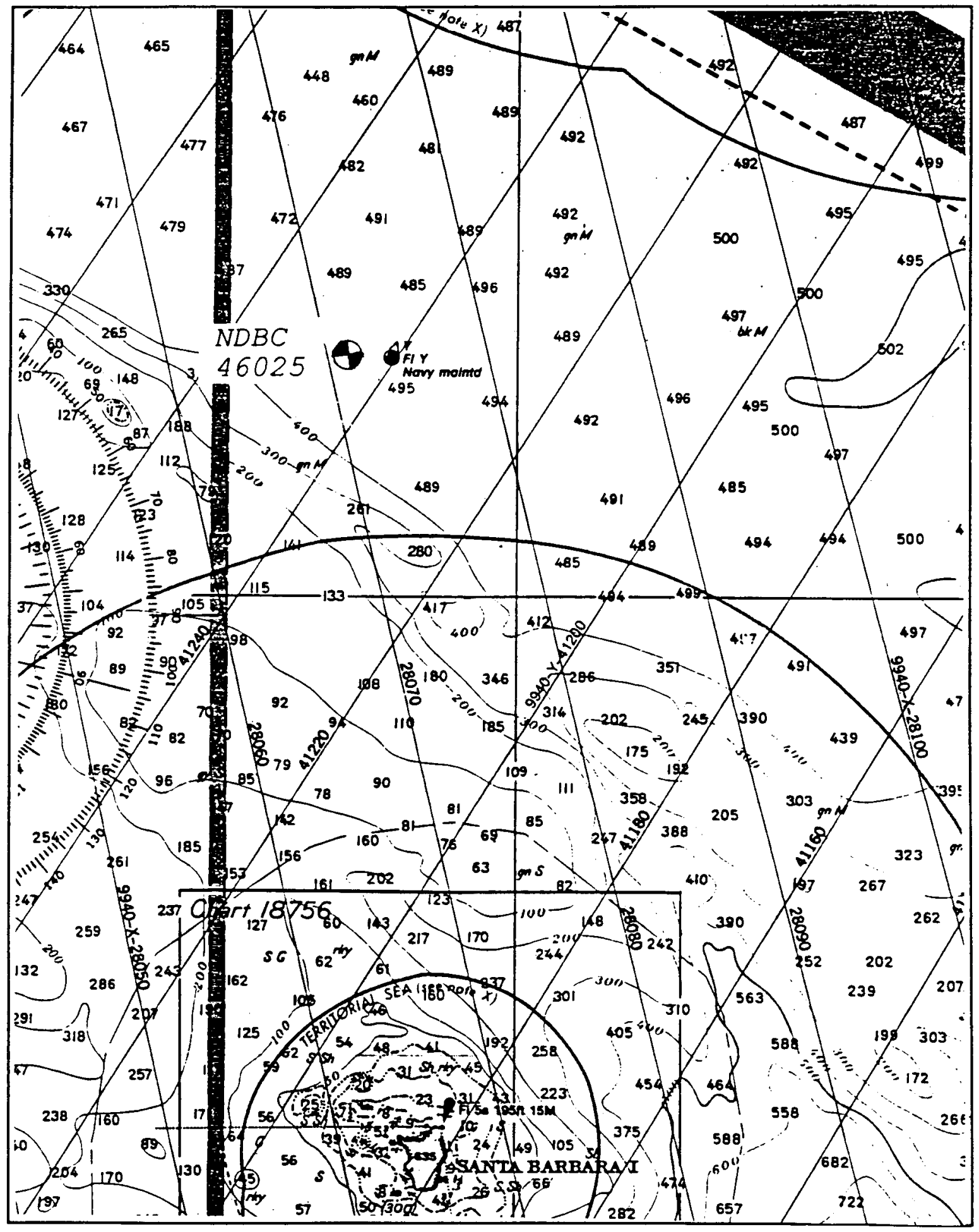

Figure 2. Location of deepwater gage (soundings in fathoms) 


\section{Nearshore Wave Conditions}

\section{Nearshore Gage Description}

Nearshore wave conditions were monitored using two different selfrecording instruments: directional wave gages (DWG-1) and pressure/ U-velocity/V-velocity (PUV) gages. Briefly, a DWG-l simultaneously measures sea-bottom pressure at three locations, internally processes the data, and records cross-power spectra. The array used is a $1.6-\mathrm{m}$ equilateral triangle with a pressure transducer at each comer. Detailed descriptions of the DWG-1 and comparisons of its performance with other directional wave gages can be found in Howell (1992). ${ }^{1}$ A PUV stores simultaneous measurements of three time series, the sea bottom hydrodynamic pressure and the two horizontal cross-axis water-particle velocities. Both DWG-1 and PUV used Paroscientific pressure transducers and the PUVs also used Marsh-McBimey electromagnetic current meters.

\section{Gage Deployment}

The first shallow-water gages were deployed in late October 1992 and recovered in mid-April 1993. A total of nine gages were deployed. Gage locations were selected to document variations in wave transformation throughout the area of interest. Site selection was guided by Hales $(1987)^{2}$ and U.S. Army Engineer District, Los Angeles (1988) ${ }^{3}$. Gage sites were designated as North (Appendix A), North Breakwater (Appendix B), Near Breakwater (Appendix C), South Breakwater (Appendix D), and Canyon (Appendix E), (see Table 1 for locations). The highest waves due to refraction

1 Howell, G. L. (1992). "A new nearshore directional wave gage." Proceedings, 23rd International Conference on Coastal Engineering, Venice, Italy. Vol 1, 297-307.

2 Hales, L. Z. (1987). "Water wave effects at Redondo Beach King Harbor, California," Miscellaneous Paper CERC-87-2, U.S. Army Engineer Waterways Experiment Station, Vicksburg, MS.

3 U.S. Army Engineer District, Los Angeles. (1988). "Feasibility report storm damage reduc. tion, Redondo Beach -- King Harbor Area, Los Angeles County. CA." Los Angeles, CA. 
would be expected between the North breakwater site (west of the curved portion of the north breakwater) and the South Breakwater site (west of the south end of the north breakwater). The North Breakwater and South Breakwater sites were chosen to monitor this concentrated wave energy. The Canyon site (located near the tip of the Redondo Canyon) was selected to measure wave energy affected by divergence over the submarine canyon. The North site (north of the harbor) was chosen to measure waves at a great distance from the Redondo canyon.

Gages were set out in pairs, with one PUV and one DWG-1 gage at each site except at the Near Breakwater site, where only a PUV gage was deployed. Data were collected from both gage types and the gage type that produced the most data was chosen as the representative data set for that site. All sites with both DWG-1s and PUVs had at least one complete data set. Both NDBC buoys provided a complete data set for the first monitoring period. First deployment data can be found in Tables A1, A2, B1, B2, C1, C2, D1, D2, E1. E2, F1, F2, G1, and G2 and Figures A1-A6, B1-B7, C1-C4, Dl-D6, E1-E6, F1-F7, and G1-G7.

The second gage deployment period was from mid-October 1993 through early June 1994. A pair of gages was installed at the South Breakwater site and single gages were installed at the North, North Breakwater, and Canyon sites. NDBC buoys 46045 and 46025 also provided data for most of the deployment period. Data from both NDBC buoys as well as from the South Breakwater and North Breakwater sites are provided to illustrate wave conditions during the second deployment period. Second deployment data are displayed in Tables H1, H2, I1, I2, J1, J2, K1, and K2 and Figures H1, H2. I1-19, $\mathrm{J} 1-\mathrm{J} 10$, and $\mathrm{K} 1-\mathrm{K} 6$.

Data were obtained from both NDBC buoys during the entire 2-year period (October 1992 - September 1994). Time series plots of data not coincident with deployment of shallow-water gages may be found in Appendix L. 


\section{Data Summary Products}

\section{Description of Parameters}

The standard parameters reported in this document are wave height, period, and direction. These parameters are derived from a two-dimensional power density spectrum of the sea surface using spectral analysis of the sensors' output and linear wave theory. The parameters are defined as follows (see the Shore Protection Manual ${ }^{1}$ for additional information):

a. Wave Height, $H_{m 0}$ : Spectrally derived wave height, in meters; equivalent to time-domain-derived significant wave height in deep water.

b. Wave period $T_{p}$ : Peak spectral period, in seconds; inverse of the frequency of the peak (highest energy) of the one-dimensional power spectrum.

c. Wave Direction, $D_{p}$ : Peak spectral direction, in degrees clockwise from true North; mean direction from which energy is coming at the peak of the one-dimensional power spectrum.

Missing data and data that failed to pass quality control tests are excluded from the summaries.

\section{Description of Products}

The following five types of data summary products are provided in this report:

a. Time series plots.

b. Mean/max tables.

1 Shore Protection Manual. (1984). 4th Ed., 2 Vols., U.S. Army Engineer Waterways Experiment Station, Coastal Engineering Research Center, U.S. Government Printing Office, Washington, DC. 
c. Percent occurrence tables.

d. Wave rose plots.

e. Sample spectral density plots.

Descriptions and examples of products are presented in the following sections of the report.

\section{Time Series Plots}

Time series plots included in this report indicate wave information collected for each gage and buoy. The plots consist of three separate sets of axes showing $H_{m 0}, T_{p}$, and $D_{p}$ for a calendar month. Different gage types collected wave data on different time schedules. The DWG-1s and NDBC buoys collected data hourly. The PUV gages collected data every $3 \mathrm{hr}$. The plots of $H_{m 0}$ and $T_{p}$ show these individual readings connected by a continuous line. The lines are continuous as long as the data were received at the expected time intervals. The line appears broken if there is one or more missed data point. For $H_{m 0}$ and $T_{p}$, isolated points of data appear as individual symbols. The plot of $D_{p}$ shows individual readings designated with a plus (+) symbol instead of a continuous line.

Time series plots of NDBC data show an $H_{m 0}$ cutoff of $0.15 \mathrm{~m}$ and a $T_{p}$ cutoff of $2.78 \mathrm{sec}$. This means that if the $H_{m 0}$ is less than $0.15 \mathrm{~m}$, no $T_{p}$ or $D_{p}$ will be reported. When the $T_{p}$ is less than $2.78 \mathrm{sec}$, no $D_{p}$ will be reported. These limitations are imposed by NDBC.

\section{Mean/Max Tables}

The mean/max tables indicate mean and maximum $H_{m 0}$ by month for the monitoring period. A mean $H_{m 0}$ is included. Other statistics listed in this table are mean $T_{p}$ (in seconds): center of most frequent 22.5-deg direction band for directional gages (in degrees azimuth); standard deviation of $H_{m 0}$ and $T_{p}$; and largest $H_{m 0}$ along with its associated $T_{p}, D_{p}$, and the date of the occurrence.

The mean/max table for Gage RB6, North Site (Table A1) indicates that while the largest mean $H_{m 0}, 1.2 \mathrm{~m}$, occurred in February 1993, the largest $H_{m 0}, 2.7 \mathrm{~m}$, occurred on March 1993 at $600 \mathrm{hr}$ Universal Coordinated Time (UTC), with an associated $T_{p}$ of $8.0 \mathrm{sec}$ and $D_{p}$ of $260 \mathrm{deg}$. 


\section{Percent Occurrence Tables}

Percent occurrence tables indicate the percent (times 100) of the total number of wave records for a given site that have a specified $H_{m 0}$ and $T_{p}$. Tables that depict the heights and period occurrences irrespective of direction are provided for all wave gage stations. Each listed percent value reflects the percent occurrence of waves at a particular $H_{m 0}$ and $T_{p}$ compared to all waves for which $H_{m 0}$ was computed. For nearshore gages, height bands are $0.5-\mathrm{m}$ increments; period bands are ten uneven increments from below $4.5 \mathrm{sec}$ to above $18.4 \mathrm{sec}$ (Table 2). Offshore gages have height bands in 1-m increments (to account for larger waves found offshore) with ten period bands at

\begin{tabular}{|c|c|c|c|}
\hline \multicolumn{4}{|c|}{$\begin{array}{l}\text { Table } 2 \\
\text { Frequency Ranges Used In Nearshore Data Analysis }\end{array}$} \\
\hline \multicolumn{2}{|c|}{ Midband } & \multirow[b]{2}{*}{$\begin{array}{l}\text { Band Range for } \\
\text { Period, sec }\end{array}$} & \multirow[b]{2}{*}{$\begin{array}{l}\text { Grouping for } \\
\text { Percent Occurrence } \\
\text { Tables, sec }\end{array}$} \\
\hline Frequency, $\mathrm{Hz}$ & Period, sec & & \\
\hline $\begin{array}{l}0.320 \\
. \\
0.222 \\
\end{array}$ & $\begin{array}{c}3.1 \\
\cdot \\
. \\
4.5\end{array}$ & $\begin{array}{l}3.0 \leq T p<3.1 \\
\cdot \\
4.4 \leq T p<4.6\end{array}$ & $3.0-4.5$ \\
\hline $\begin{array}{l}0.213 \\
0.203 \\
0.200 \\
0.187 \\
0.182\end{array}$ & $\begin{array}{l}4.7 \\
4.9 \\
5.0 \\
5.3 \\
5.5\end{array}$ & $\begin{array}{l}4.6 \leq T p<4.8 \\
4.8 \leq T p<4.9 \\
4.9 \leq T p<5.1 \\
5.1 \leq T p<5.4 \\
5.4 \leq T p<5.6\end{array}$ & $4.6-5.6$ \\
\hline $\begin{array}{l}0.175 \\
0.167 \\
0.161 \\
0.152 \\
0.143 \\
0.137 \\
0.128 \\
\end{array}$ & $\begin{array}{l}5.7 \\
6.0 \\
6.2 \\
6.6 \\
7.0 \\
7.3 \\
7.8 \\
\end{array}$ & $\begin{array}{l}5.6 \leq T p<5.8 \\
5.8 \leq T p<6.1 \\
6.1 \leq T p<6.4 \\
6.4 \leq T p<6.8 \\
6.8 \leq T p<7.1 \\
7.1 \leq T p<7.5 \\
7.5 \leq T p<8.0\end{array}$ & $5.6 \cdot 8.0$ \\
\hline $\begin{array}{l}0.120 \\
0.111 \\
0.105 \\
0.097 \\
\end{array}$ & $\begin{array}{r}8.3 \\
9.0 \\
9.5 \\
10.3 \\
\end{array}$ & $\begin{array}{l}8.0 \leq T p<8.6 \\
8.6 \leq T p<9.2 \\
9.2 \leq T p<9.8 \\
9.8 \leq T p<10.6\end{array}$ & $8.0 \cdot 10.6$ \\
\hline $\begin{array}{l}0.091 \\
0.082 \\
0.074 \\
0.066 \\
0.058\end{array}$ & $\begin{array}{l}11.0 \\
12.2 \\
13.6 \\
15.1 \\
17.1 \\
\end{array}$ & $\begin{array}{l}10.6 \leq T p<11.6 \\
11.6 \leq T p<12.7 \\
12.7 \leq T p<14.1 \\
14.1 \leq T p<15.9 \\
16.0 \leq T p<18.3\end{array}$ & $\begin{array}{l}10.6 \cdot 11.6 \\
11.6 \cdot 12.7 \\
12.8 \cdot 14.1 \\
14.2 \cdot 15.9 \\
16.0 \cdot 18.3\end{array}$ \\
\hline $\begin{array}{l}0.050 \\
0.027\end{array}$ & $\begin{array}{c}19.8 \\
\cdot \\
\cdot \\
36.4\end{array}$ & $\begin{array}{c}18.4 \leq T_{p}<21.3 \\
32.0 \leq T_{p}<40.9\end{array}$ & 18.4 - longer \\
\hline
\end{tabular}


uneven increments from below $6.9 \mathrm{sec}$ to above $18.2 \mathrm{sec}$ (Table 3). Totals of the height category are provided at the right of each height row. Totals for each period range are at the bottom of each period column. Results are in summary form at the bottom of the tables showing the mean $H_{m 0}$ and $T_{p}$, the largest $H_{m 0}$, and the total number of cases represented by the table.

\begin{tabular}{|c|c|c|c|}
\hline \multicolumn{4}{|c|}{$\begin{array}{l}\text { Table } 3 \\
\text { Frequency Ranges Used in Offshore Data Analysis }\end{array}$} \\
\hline \multicolumn{2}{|c|}{ Midband } & \multirow[b]{2}{*}{$\begin{array}{l}\text { Band Range for } \\
\text { Period, sec }\end{array}$} & \multirow[b]{2}{*}{$\begin{array}{l}\text { Grouping for } \\
\text { Percent Occurrence } \\
\text { Tables, sec }\end{array}$} \\
\hline Frequency, $\mathrm{Hz}$ & Period, sec & & \\
\hline 0.400 & 2.5 & $2.22 \leq T_{p}<2.86$ & \\
\hline . & . & & $<6.9$ \\
\hline 0.160 & 4.5 & $6.06 \leq T p<6.45$ & \\
\hline 0.150 & 6.7 & $6.45 \leq T_{p}<6.90$ & \\
\hline 0.140 & 7.1 & $6.90 \leq T p<7.41$ & $6.9-8.0$ \\
\hline 0.130 & 7.7 & $7.41 \leq T p<8.00$ & \\
\hline 0.120 & 8.3 & $8.00 \leq T p<8.70$ & $8.1-8.7$ \\
\hline 0.110 & 9.1 & $8.70 \leq T p<9.52$ & $8.8-9.5$ \\
\hline 0.100 & 10.0 & $9.52 \leq T p<10.53$ & $9.6-10.5$ \\
\hline 0.090 & 11.1 & $10.53 \leq T p<11.76$ & $10.6-11.7$ \\
\hline 0.080 & 12.5 & $11.76 \leq T_{p}<13.33$ & $11.8-13.3$ \\
\hline 0.070 & 14.3 & $13.33 \leq T p<15.38$ & $13.4 \cdot 15.3$ \\
\hline 0.060 & 16.7 & $15.38 \leq T p<18.18$ & $15.4 \cdot 18.1$ \\
\hline 0.050 & 20.0 & $18.18 \leq T p<22.22$ & \\
\hline 0.040 & 25.0 & $22.22 \leq T_{p}<28.57$ & 18.2 - longer \\
\hline 0.030 & 33.3 & $28.57 \leq T p<40.00$ & \\
\hline
\end{tabular}

In order to determine what percent of the wave records from Gage 030 , Near Breakwater, have an $H_{m 0}$ of $2.0-2.4 \mathrm{~m}$ with a $T_{p}$ of $5.6-8.0 \mathrm{sec}$, the percent occurrence table for that station (Table $\mathrm{C} 2$ ) is consulted. The value 34 is found where the $2.0-$ to $2.4-\mathrm{m}$ height row intersects with the $5.6-$ to $8.0-\mathrm{scc}$ period column. Divide this number by 100 to get the percent. Thus, 5.6- to 8 -sec waves from 2 to $2.4 \mathrm{~m}$ would be expected only about 0.34 percent of the time.

\section{Wave Rose Diagrams}

The wave rose diagrams indicate mean $H_{m 0}$ and the compass direction from which the waves are coming. The scale of the rose is set so the outer edge 
will be slightly larger than the largest mean wave height for the given wave gage station. Three evenly spaced concentric circles within the rose delineate lesser mean wave heights. The value indicated by each circle is differentiated through the use of a distinct line type. Wave directions are grouped in 22.5-deg bands centered on 0,22.5, $45 \mathrm{deg}$, etc. Mean $H_{m 0}$ and percent of samples for each direction band are represented in the wedge-shaped portions of the rose plots. The length (or radius) of the wedge describes the mean $\mathrm{H}_{m 0}$, while the shading of the wedge tells what percent of the samples come from that direction. Only data records that have both $D_{p}$ and $H_{m 0}$ are used in developing the wave roses.

The wave rose diagram for Gage RB5, Canyon (Figure E6), indicates a mean $H_{m 0}$ of $0.92 \mathrm{~m}$ for the azimuth band centered on $270 \mathrm{deg}$; and for this time interval, more than 15 percent of the $D_{p}$ values are within the 270-deg azimuth band. This wave rose diagram also tells at a glance that no waves of any size occurred from the south through the southeast.

\section{Spectral Density Plots}

Because of their bulk, all of the spectral data cannot be included in this report. Characteristic spectra are shown in Figure 3. The example provided illustrates characteristic long-period swell propagation from deep to shallow water. The three-dimensional axes show frequency (Hertz) on the $x$ axis, elapsed time (hours) on the $y$ axis and energy density $\left(\mathrm{m}^{2} / \mathrm{Hz}\right)$ on the $\mathrm{z}$ axis. Plots show spectral density for the deepwater NDBC buoy (46025) (North Breakwater site and Canyon site) for the period 1-10 February 1993. 

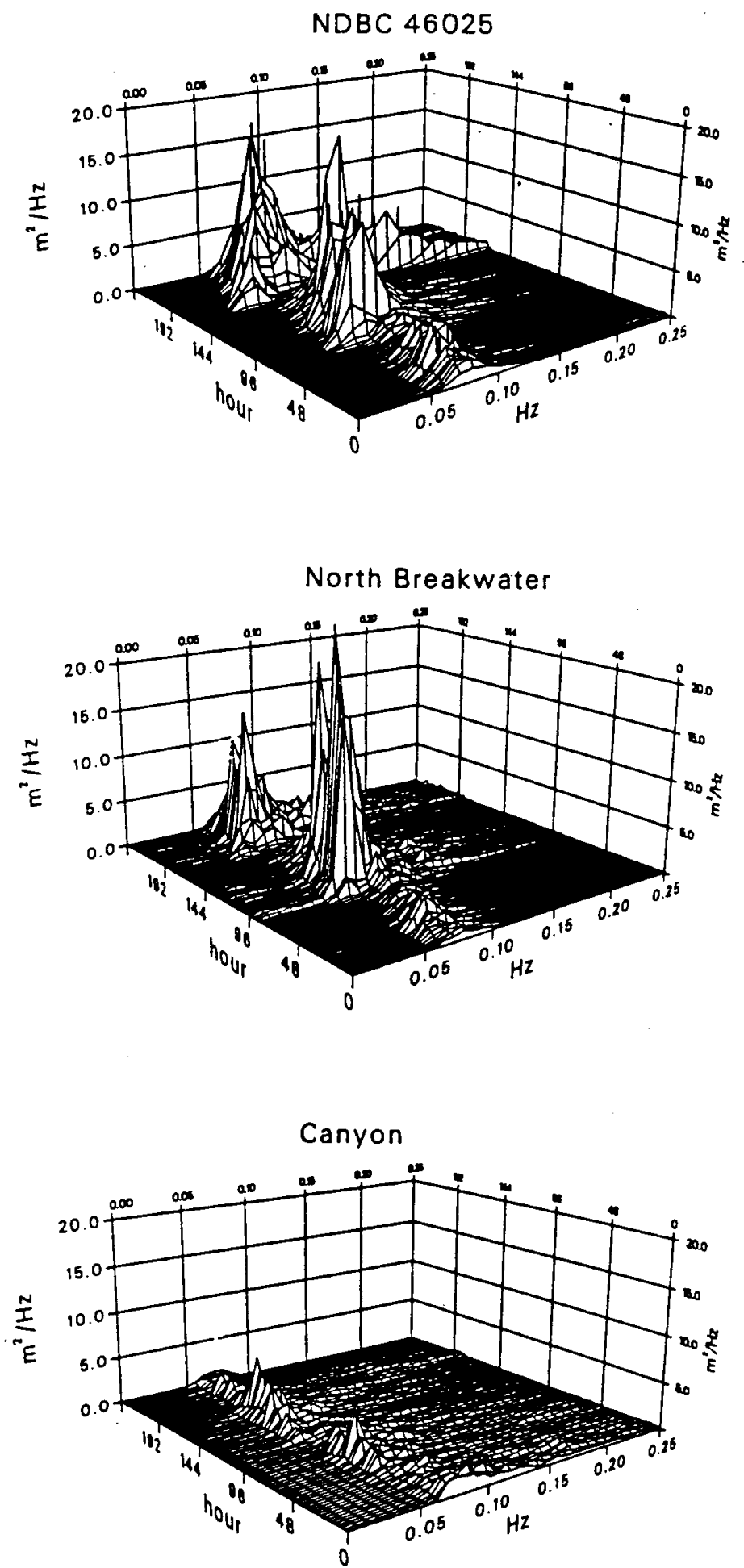

Figure 3. Example swell spectra, 1-10 February 1993 


\section{Appendix A North Site, First Deployment}




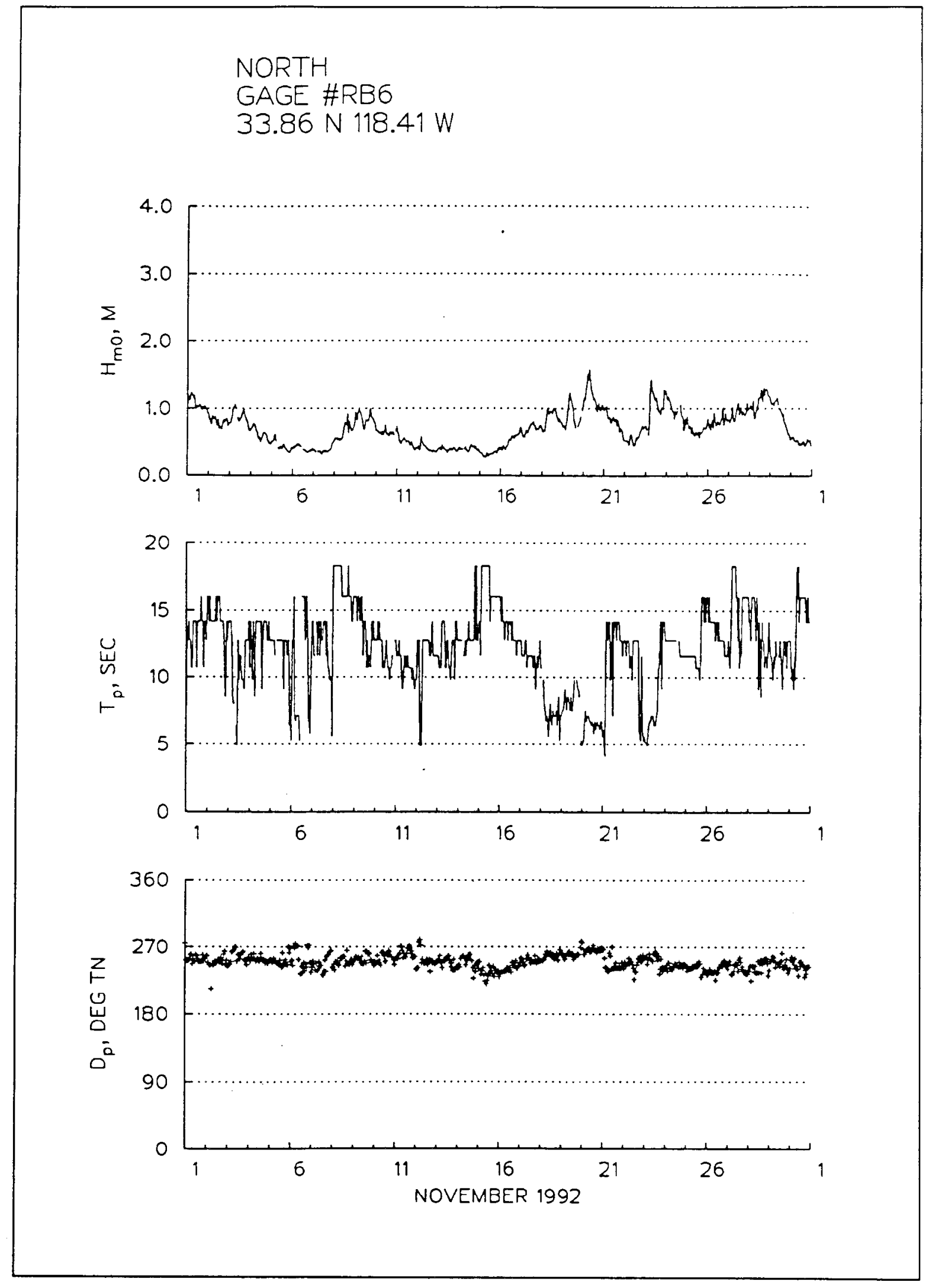

Figure A1. Time series plot for North (gage RB6), November 1992, first deployment $\mathrm{A} 2$ 


\section{NCRTH}

G. GE \#RB6

$33.86 N 118.41 \mathrm{~W}$
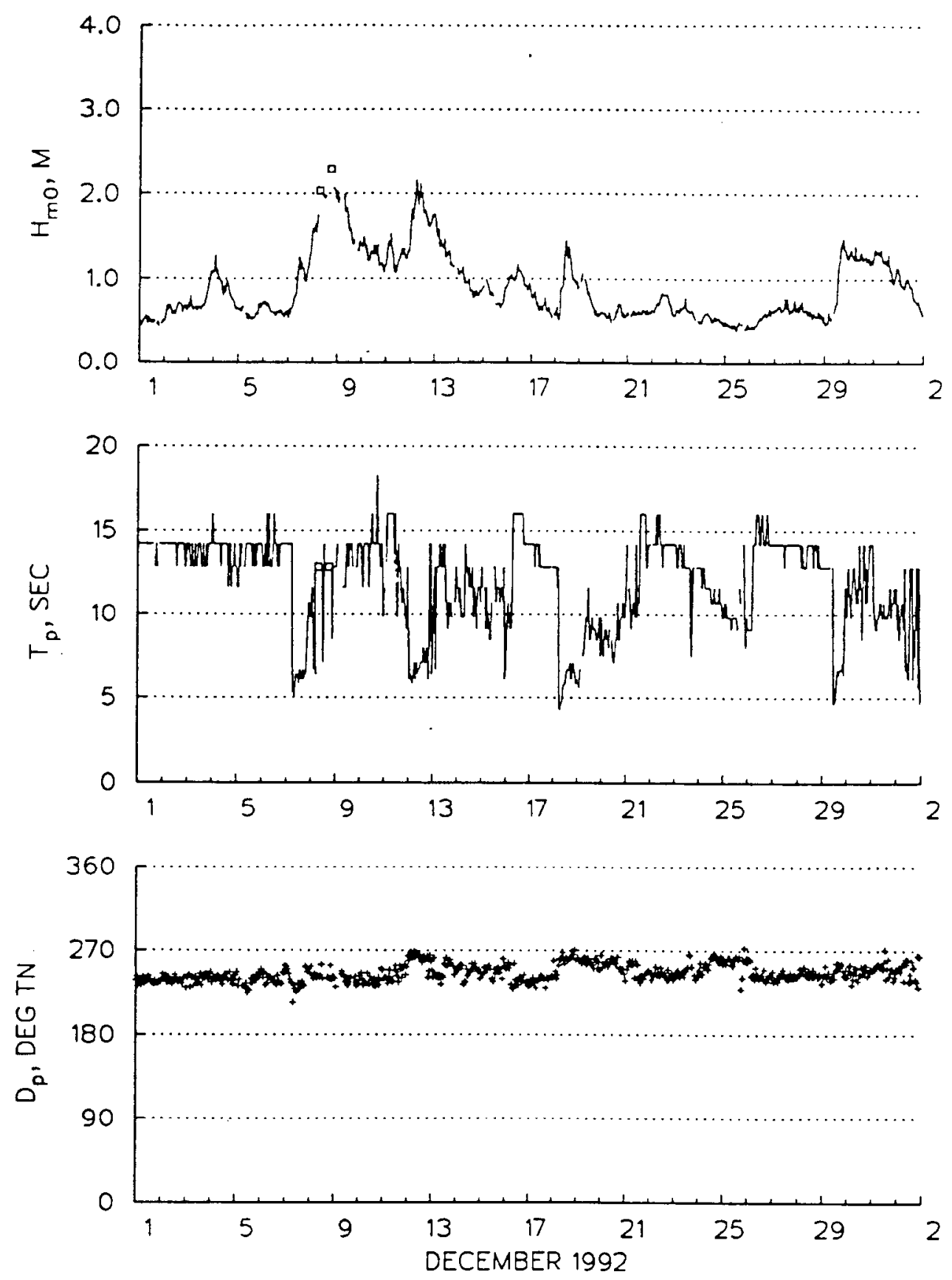

Figure A2. Time series plot for North (RB6) gage, December 1992, first deployment 
NORTH

GAGE \#RBG

33.86 N $118.41 \mathrm{~W}$
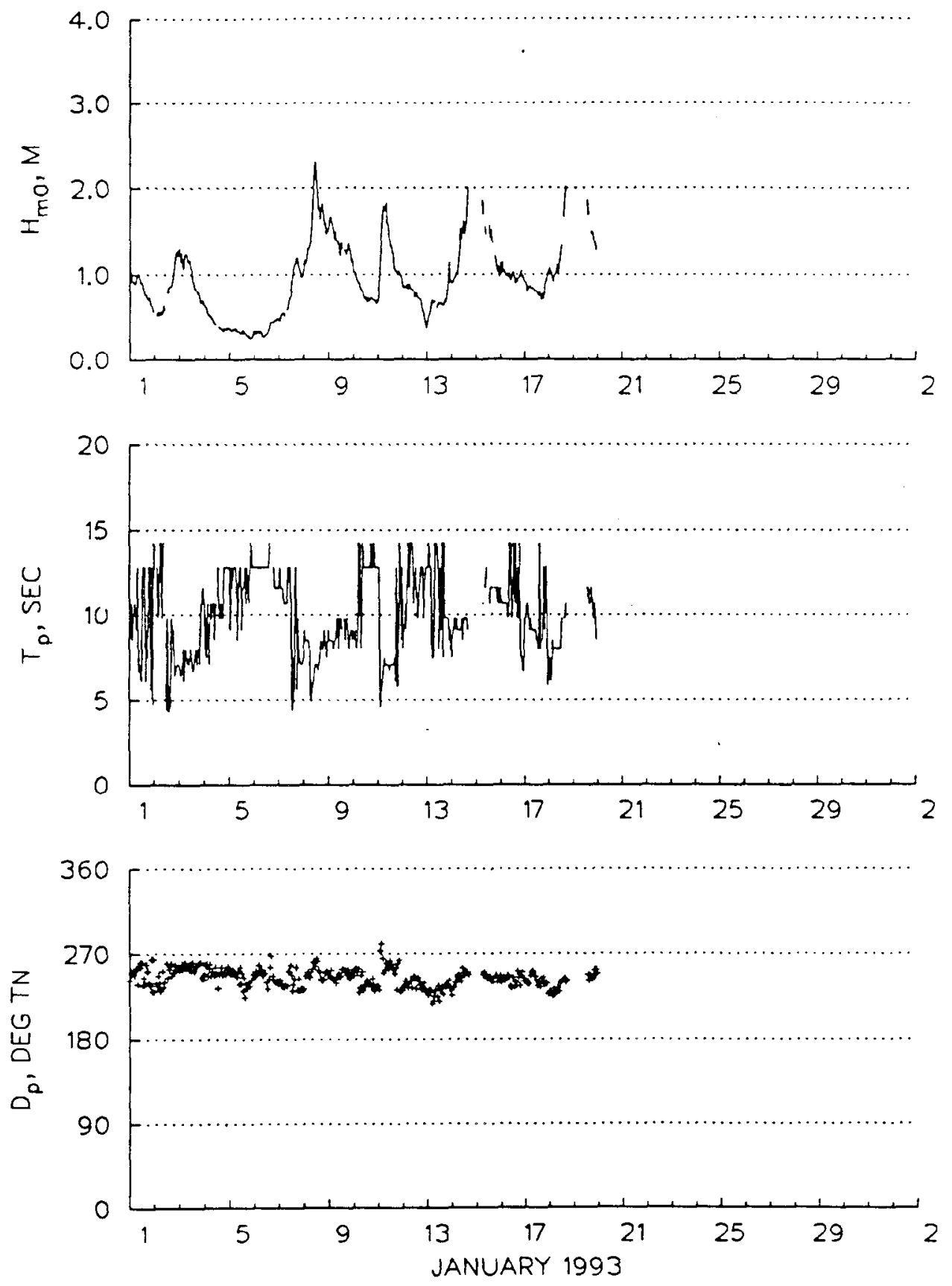

Figure A3. Time series plot for North (RB6) gage, January 1993, first deplayment A4 


\section{NORTH}

GAGE \#RB6

$33.86 \mathrm{~N} 118.41 \mathrm{~W}$
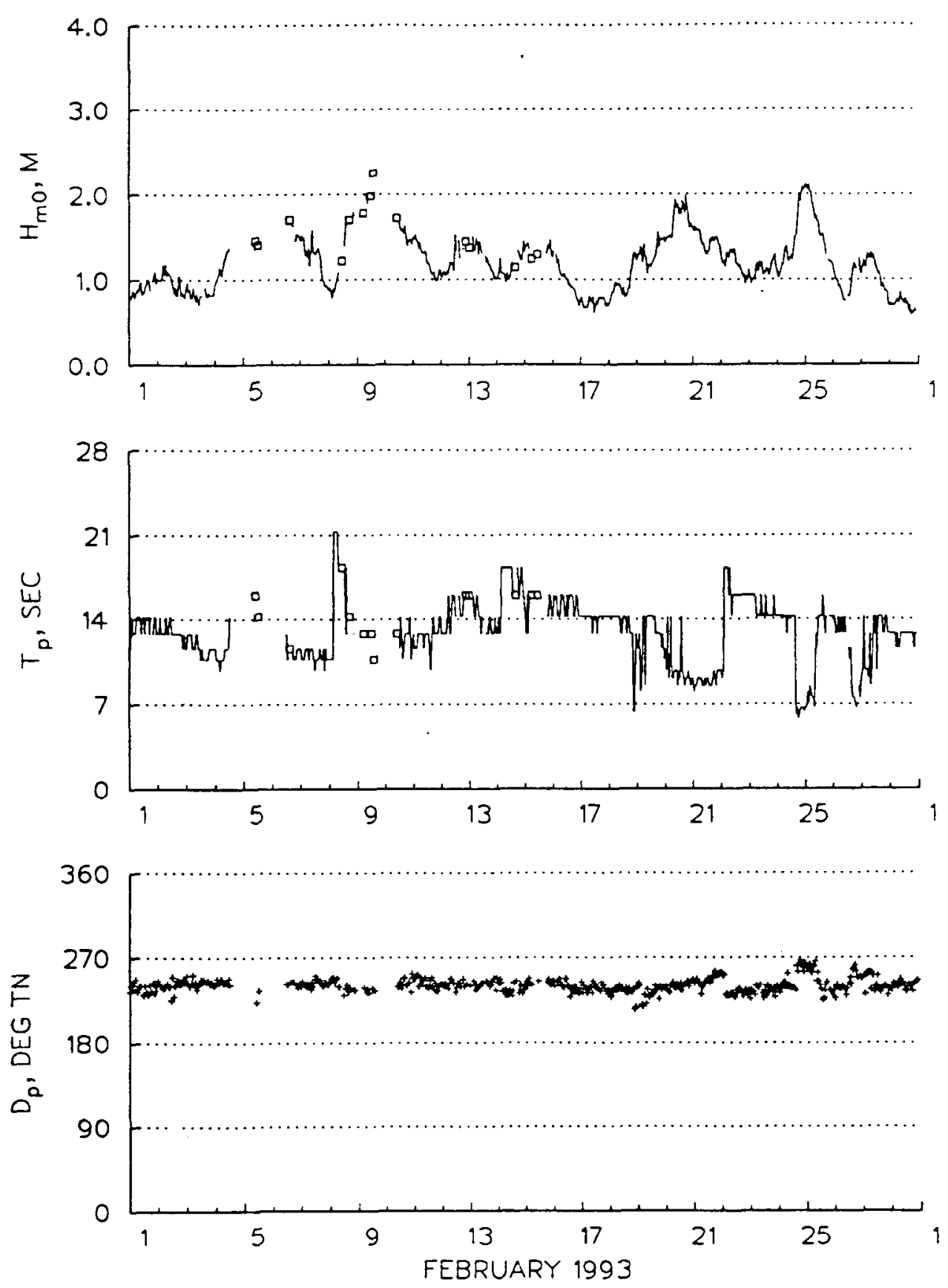

Figure A4. Time series plot for North (RB6) gage, February 1993, first deployment 


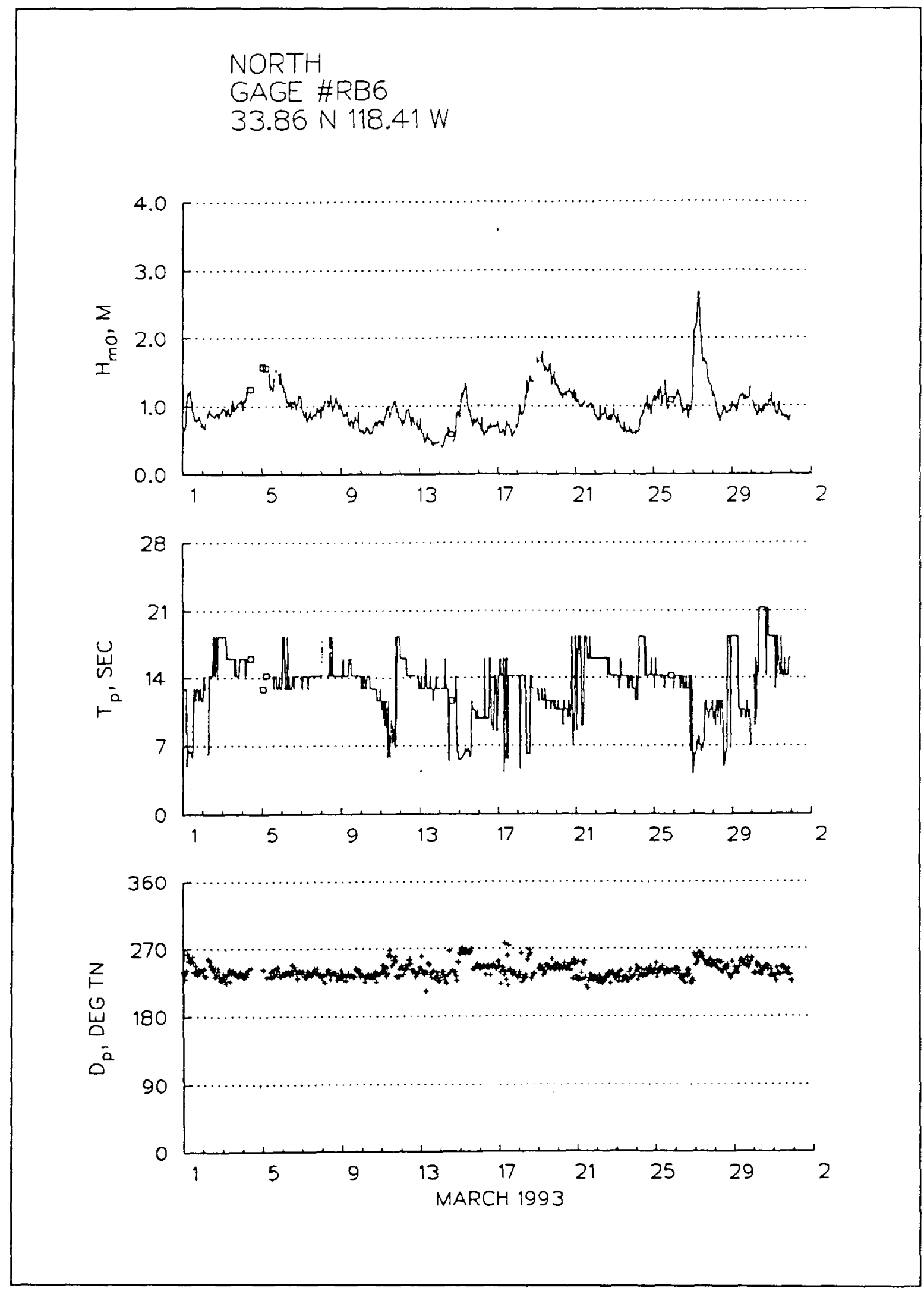

Figure A5. Time series plot for North (RB6) gage, March 1993, first deployment A6 


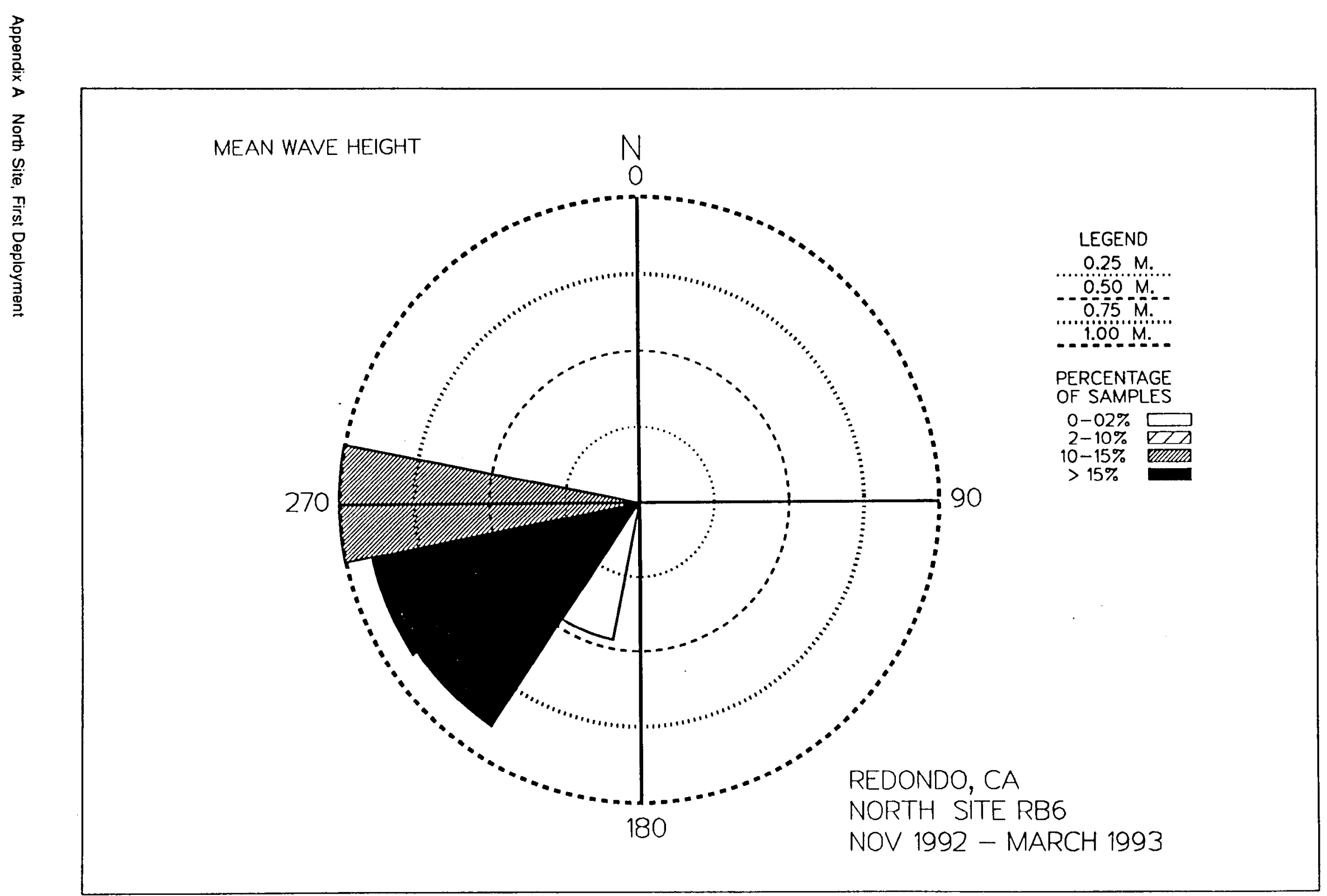

Figure A6. Wave rose for North (RB6) gage, first deployment 


\section{Table A1}

Mean/Max Values for North (RB6)

First Deployment

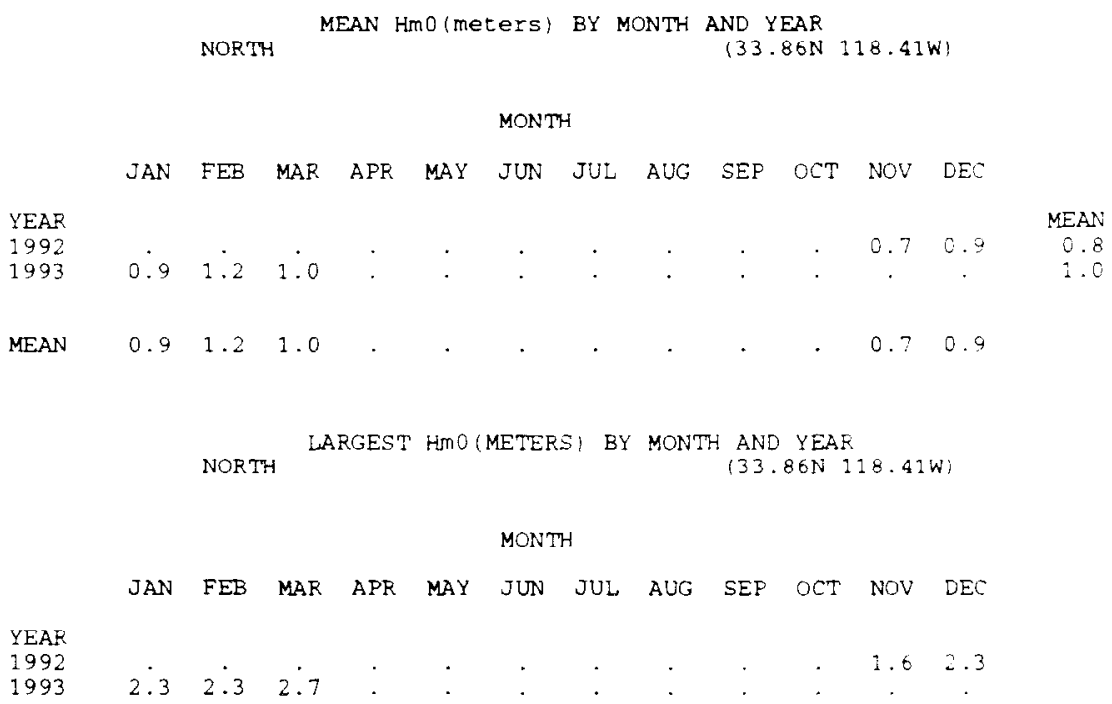

THE MEAN SIGNIFICANT WAVE HEIGHT(METERS) =

THE MOST FREQUENT 22.5 (CENTER) DIRECTION BAND (DEGREES) =

247.5

THE STANDARD DEVIATION OF HMO(METERS) =

THE STANDARD DEVIATION OF TP (SECONDS) =

THE LARGEST HMO (METERS) =

THE TP(SECONDS)ASSOC. WITH THE LARGEST HMO=

THE PEAK DIRECTION (DEGREES) ASSOC. WITH THE LARGEST HMO= 
Table A2

Percent Occurrence for North (RB6)

First Deployment

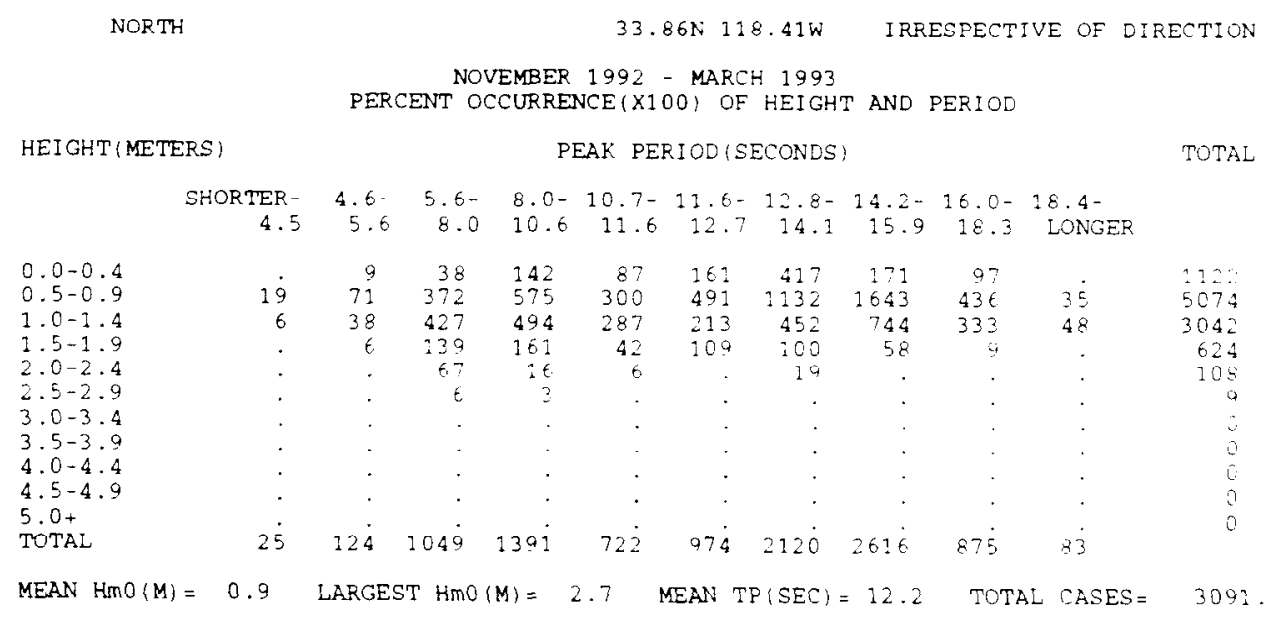




\section{Appendix B North Breakwater Site, First Deployment}


NORTH BREAKWATER

GAGE \#020

$33.85 \mathrm{~N} 118.41 \mathrm{~W}$
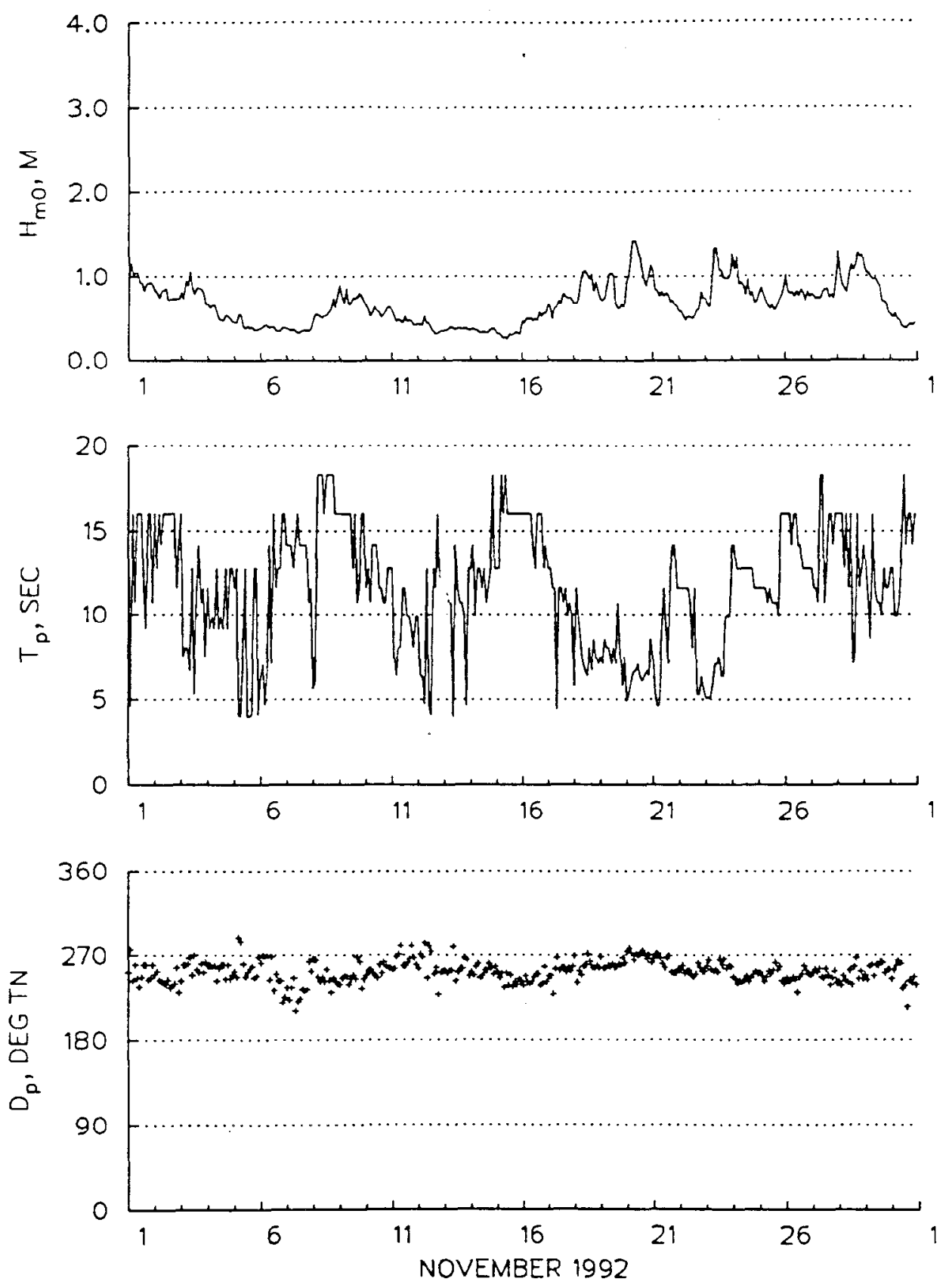

Figure B1. Time series plot for North Breakwater gage (020), November 1992, first deployment 
NORTH BREAKWATER

GAGE \#020

$33.85 N 118.41 \mathrm{~W}$
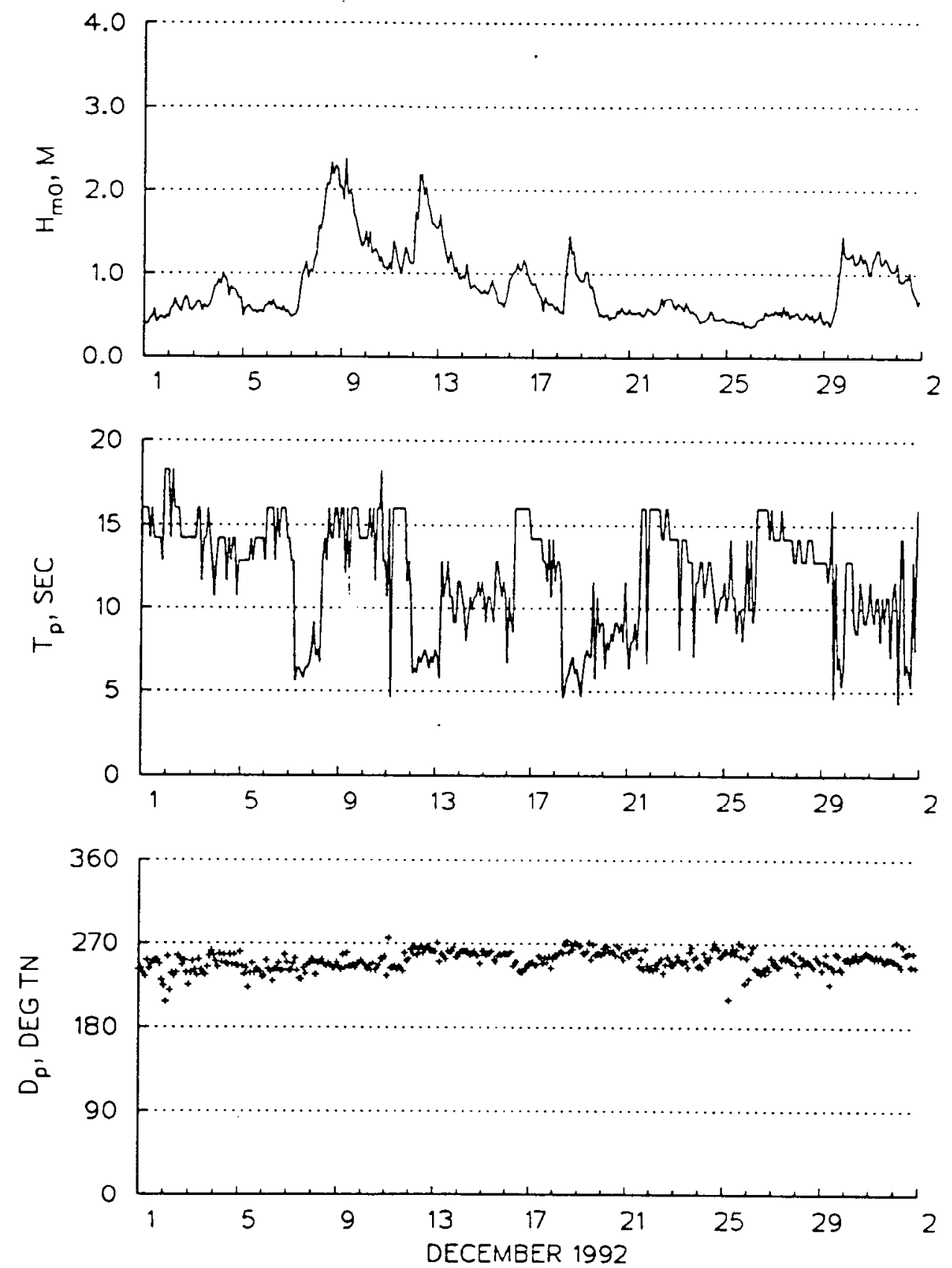

Figure B2. Time series plot for North Breakwater gage (020), December 1992, first deployment 
NORTH BREAKWATER

GAGE \#020

$33.85 \mathrm{~N} 118.41 \mathrm{~W}$
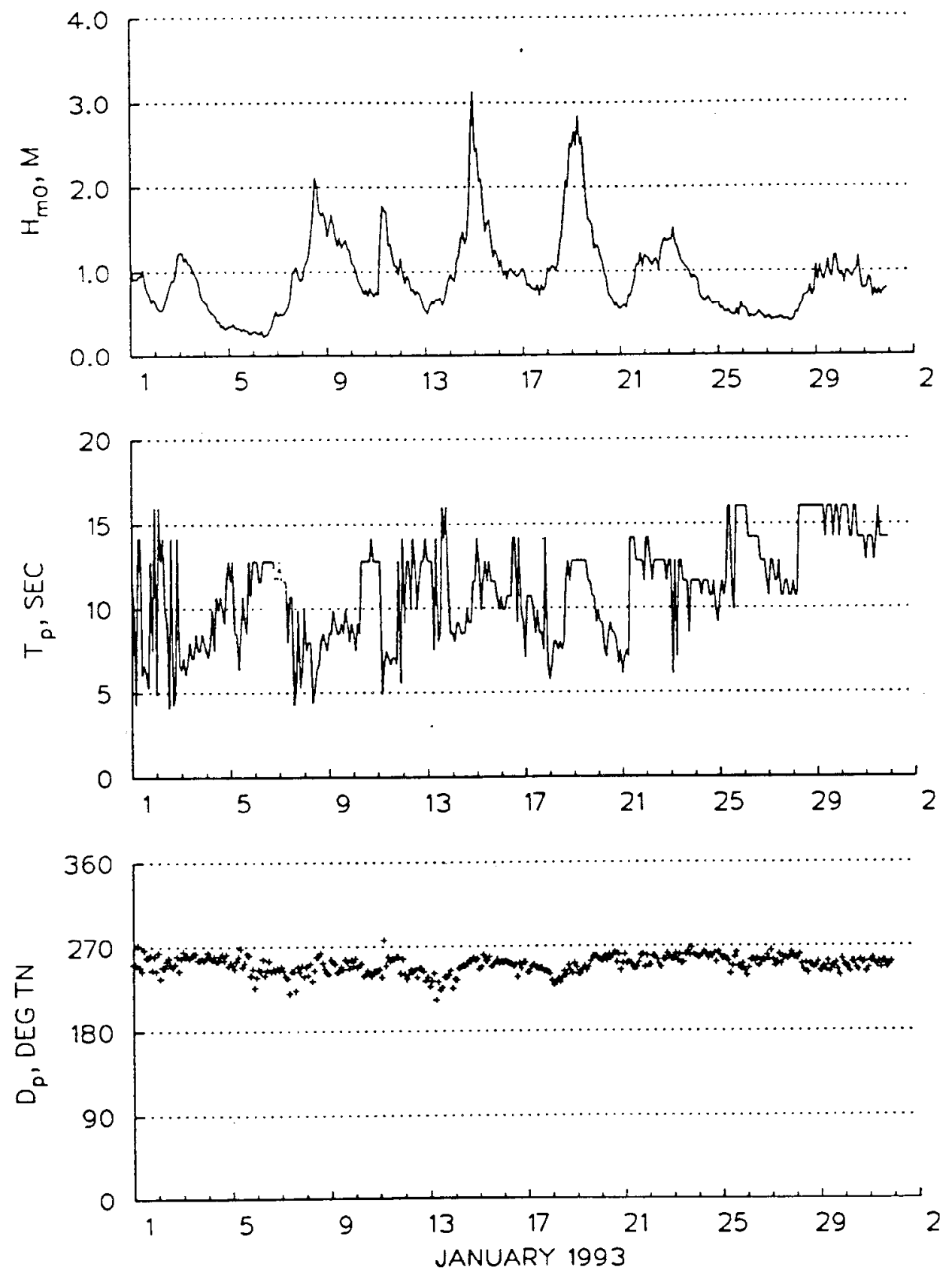

Figure B3. Time series plot for North Breakwater gage (020), January 1993, first deployment 
NORTH BREAKWATER

GAGE \#020

$33.85 N 118.41 \mathrm{~W}$
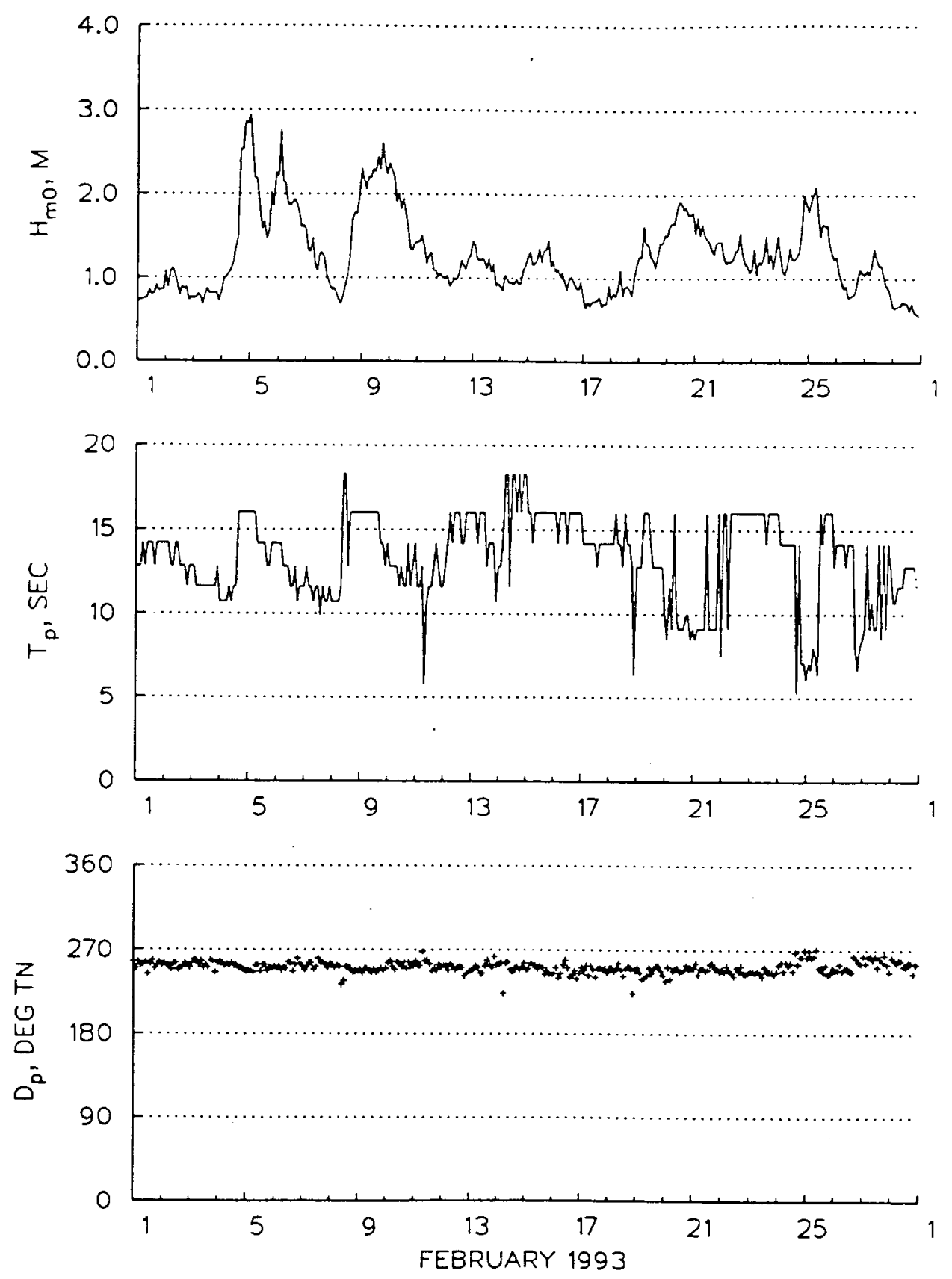

Figure B4. Time series plot for North Breakwater gage (020), February 1993, first deployment 
NORTH BREAKWATER

GAGE \#020

$33.85 N 118.41 \mathrm{~W}$
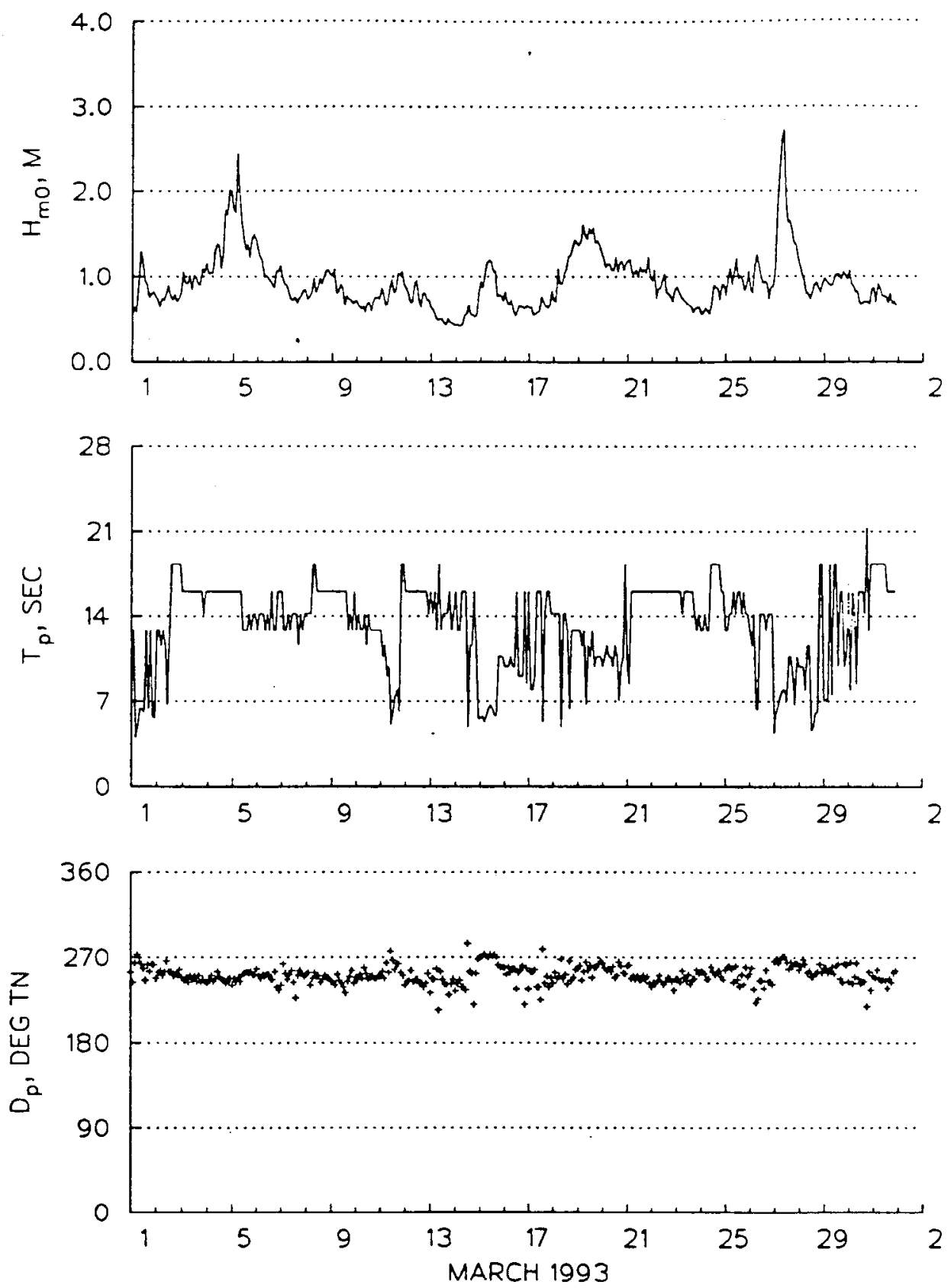

Figure B5. Time series plot for North Breakwater gage (020), March 1993, first deployment 


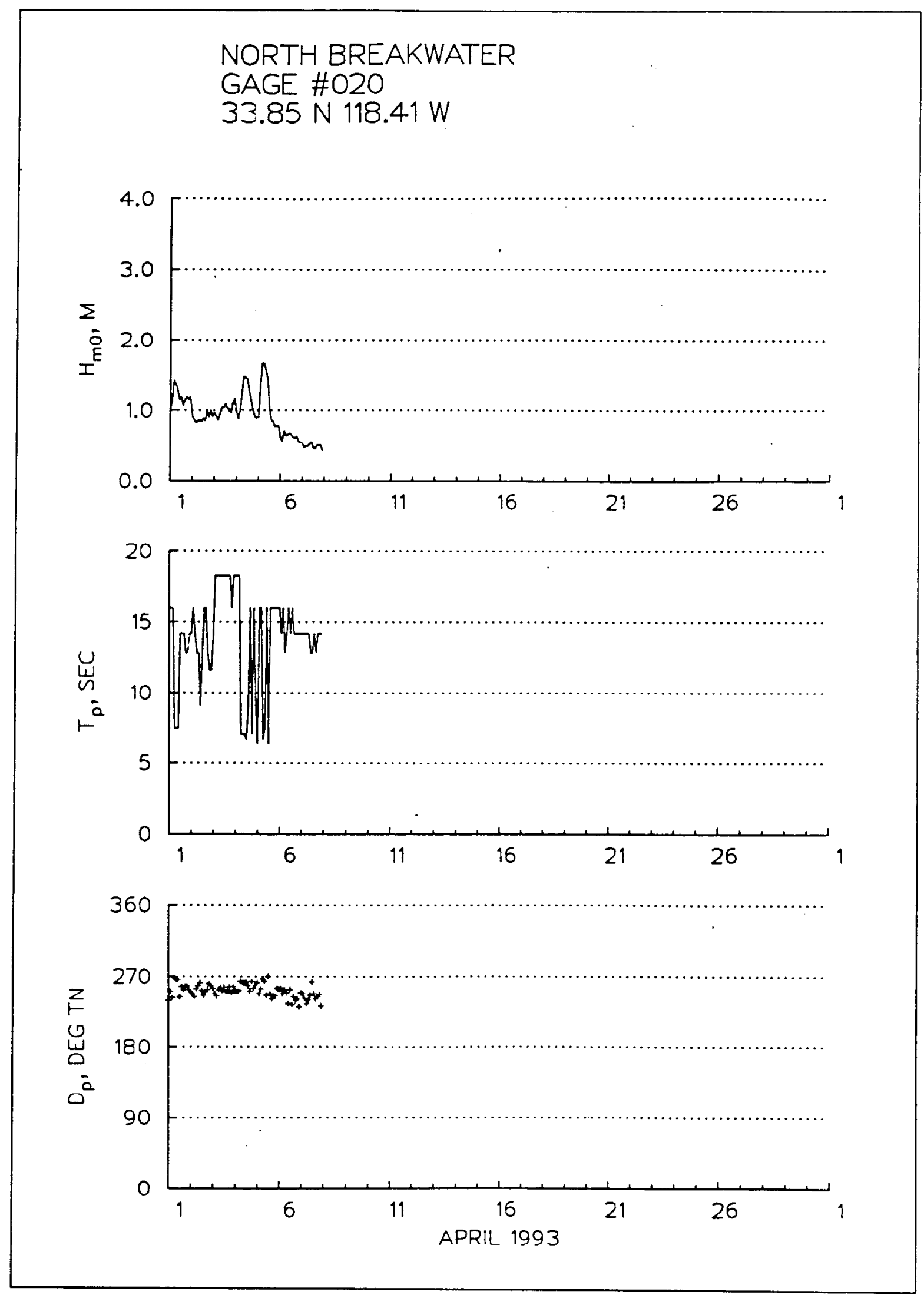

Figure B6. Time series plot for North Breakwater gage (020), April 1993, first deployment 


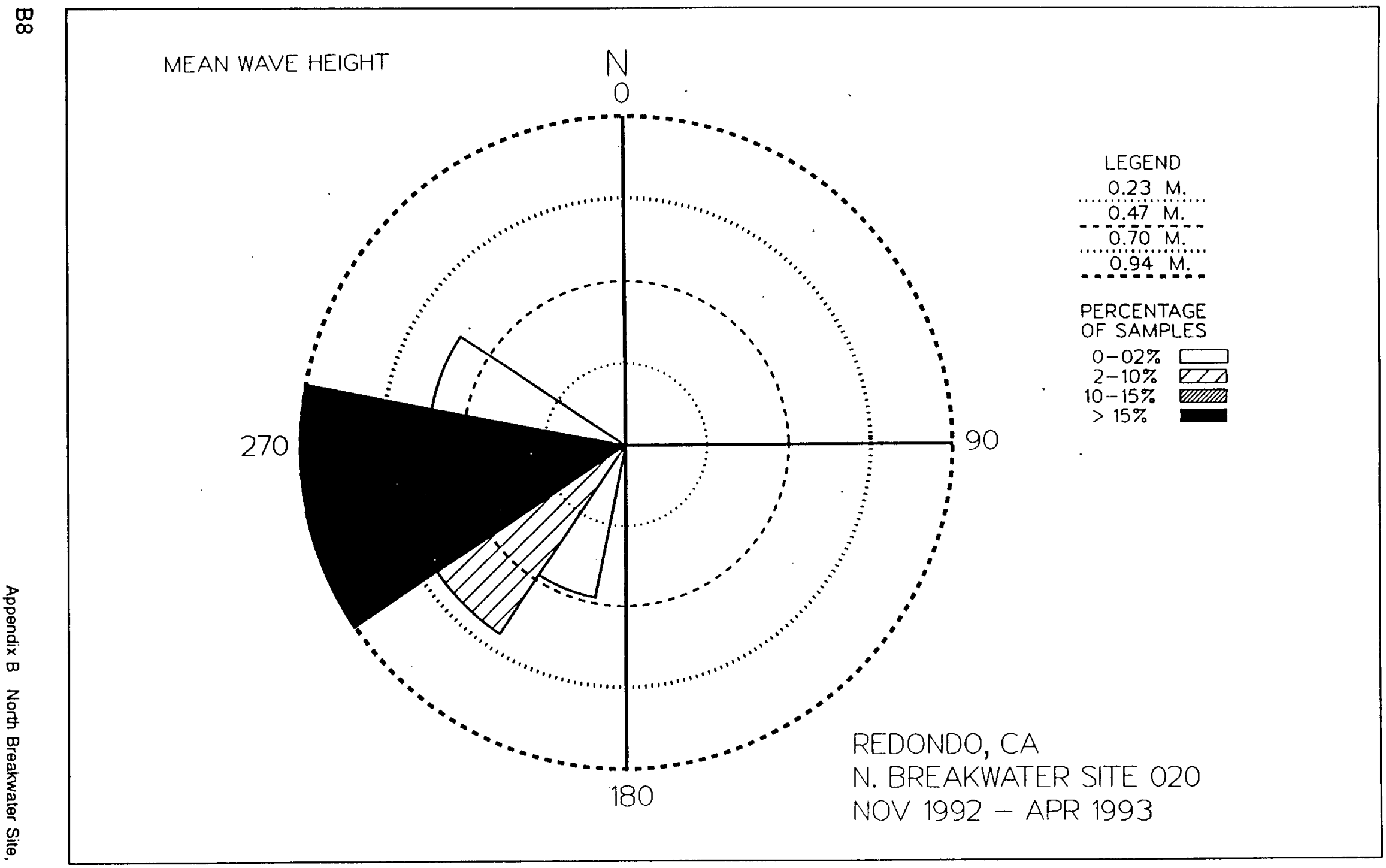

Figure B7. Wave rose for North Breakwater gage (020), first deployment 
Table B1

Mean/Max Values for North Breakwater (020)

First Deployment

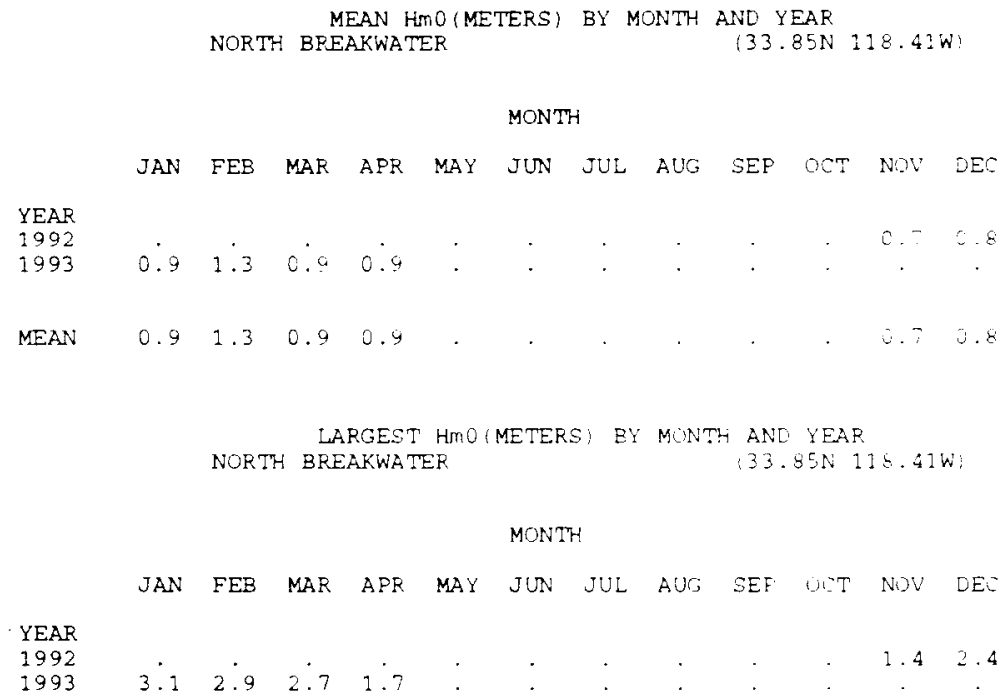

THE MEAN SIGNIFICANT WAVE HEIGHT(METERS) =

THE MEAN PEAK WAVE PERIOD (SECONDS) =

12.3

THE MOST FREQUENT 22.5 (CENTER) DIRECTION BANL (DEGREES) =

247.5

THE STANDARD DEVIATION OF HMO (METEPS) =

THE STANDARD DEVIATION OF TP(SECONDS) =

$3 \cdot 4$

THE LARGEST HMO $($ METERS $)=$

THE TP(SECONDS) ASSOC. WITH THE LARGEST HMO =

THE PEAK DIRECTION (DEGREES) ASSOC. WITH THE LARGEST HMO= 
Table B2

Percent Occurrence for North Breakwater(020)

First Deployment

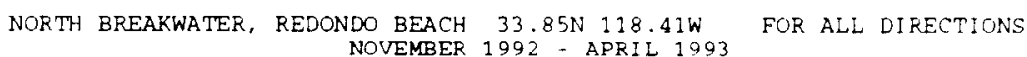
PERCENT OCCURRENCE $(X 100)$ OF HEIGHT AND PERIOD

HEIGHT (METERS )

PEAK PERIOD(SECONDS)

TOTAL

SHORTER- 4.6- 5.6-8.0-10.7-11.6-12.8-14.2-16.0-18.4

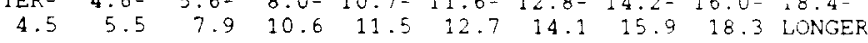

$0.0-0.4$

$0.5-0.9$

$1.0-1.4$

$1.5-1.9$

$2.0-2.4$

$2.5-2.9$

$3.0-3 \cdot 4$

$3.5-3.9$

$4.0-4.4$

2.0+

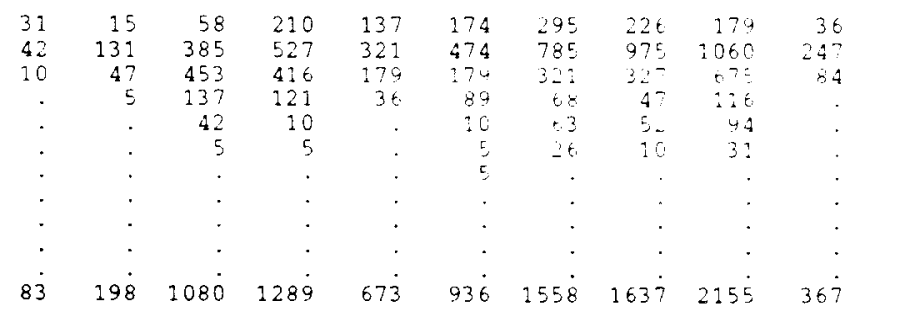

$136:$
494

bis?

619

OTAL

LARGEST HMO $(M)-3.1$

MEAN $T P(S E C)=12.3$ TOTAL CASES $=$ 


\section{Appendix C \\ Near Breakwater Site, First \\ Deployment}




\section{NEAR BREAKWATER \\ GAGE \#030 \\ $33.85 \mathrm{~N} 118.40 \mathrm{~W}$}
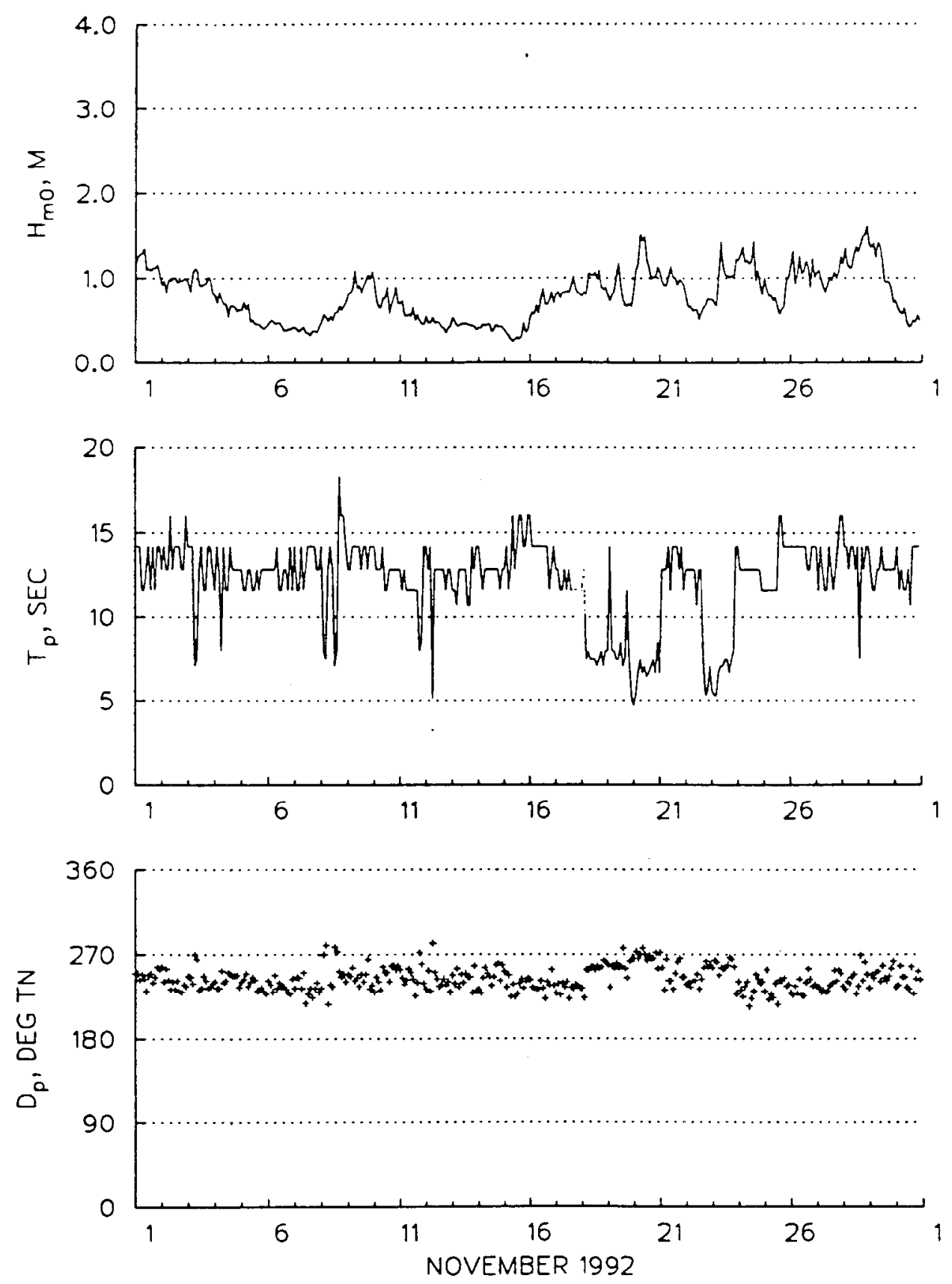

Figure C1. Time series plot for Near Breakwater gage (030), November 1992, first deployment 
NEAR BREAKWATER

GAGE \#030

$33.85 N 118.40 \mathrm{~W}$
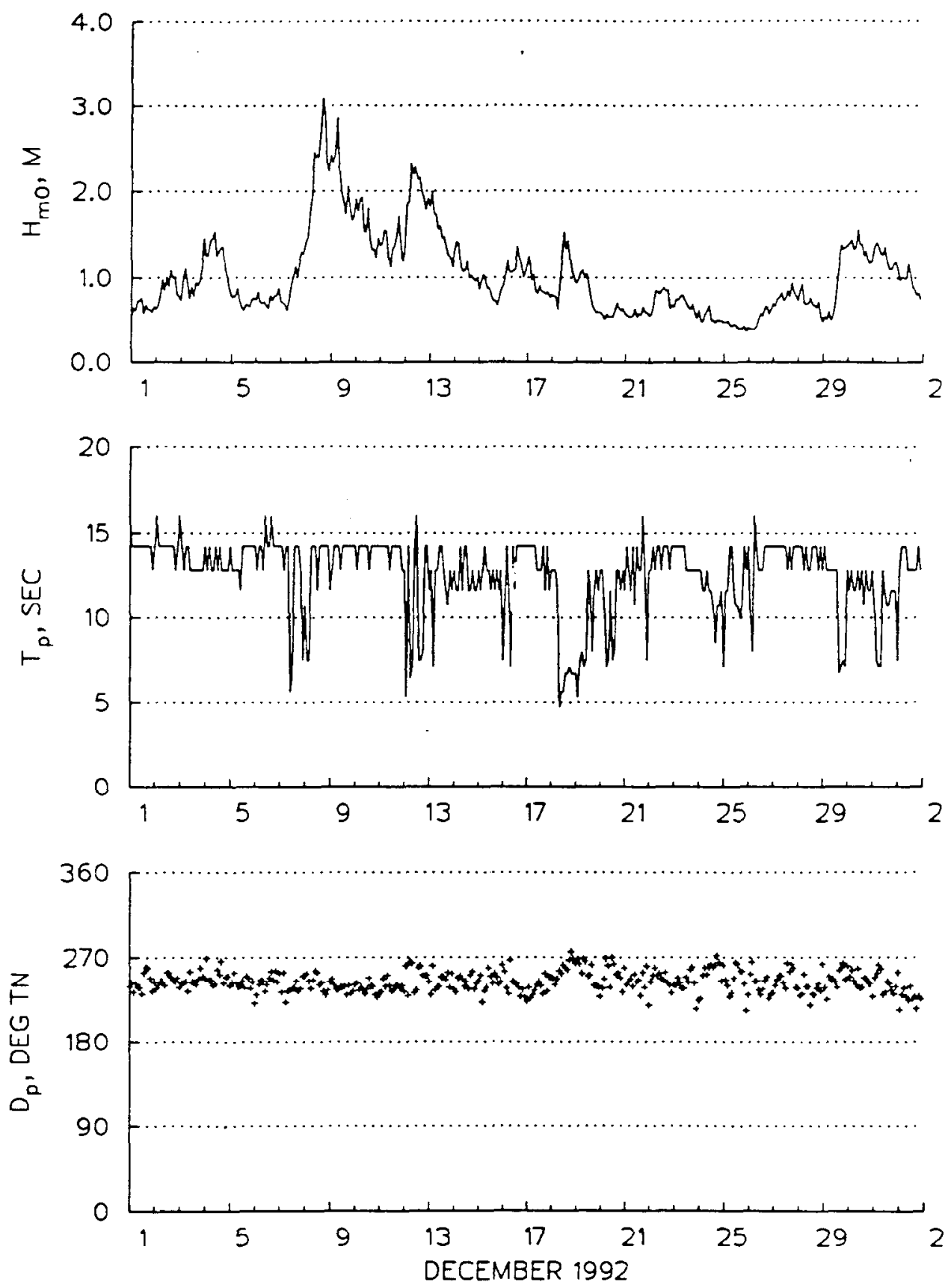

Figure C2. Time series plot for Near Breakwater gage (030), December 1992, first deployment 


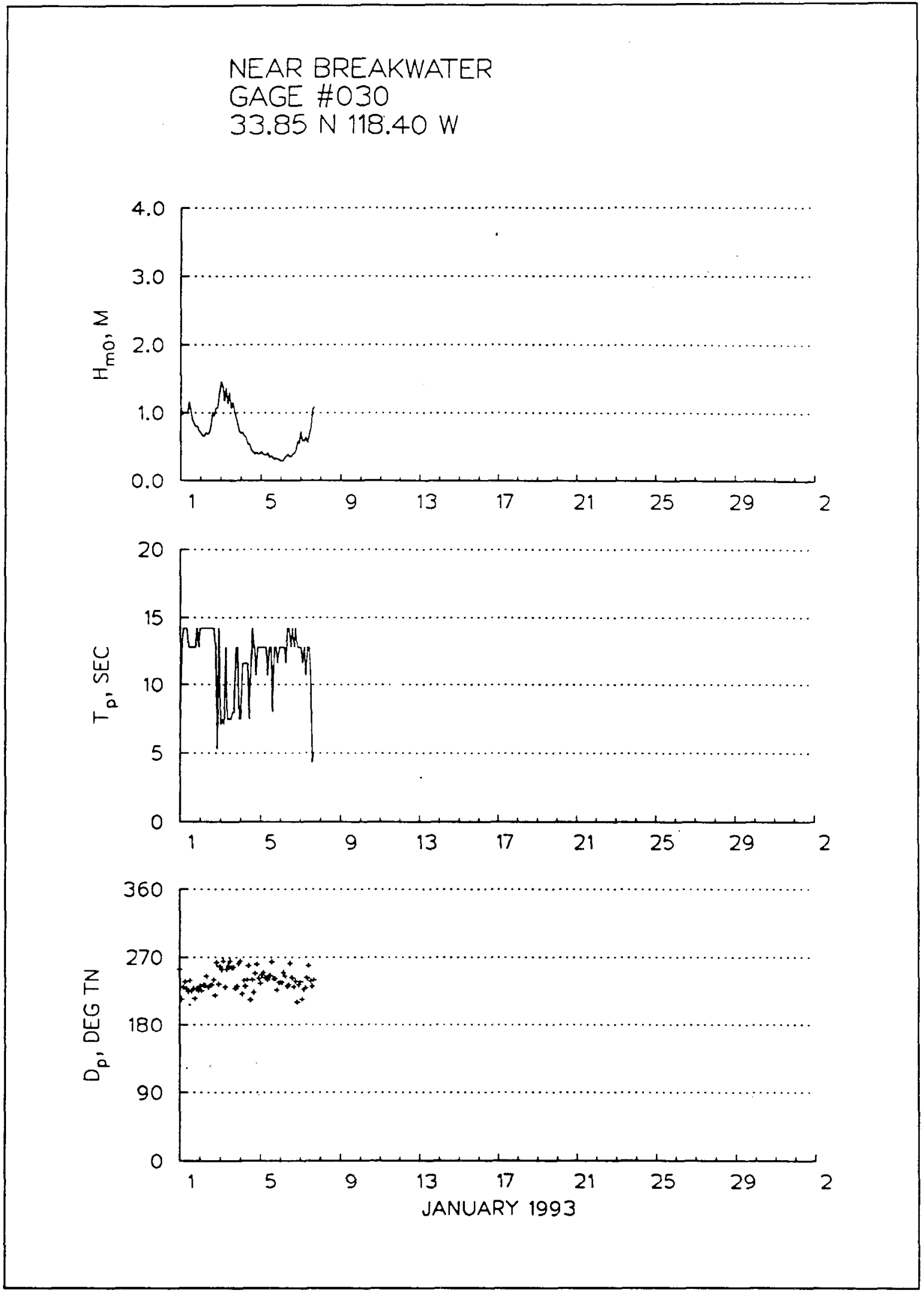

Figure C3. Time series plot for Near Breakwater gage (030), January 1993, first deployment C4 


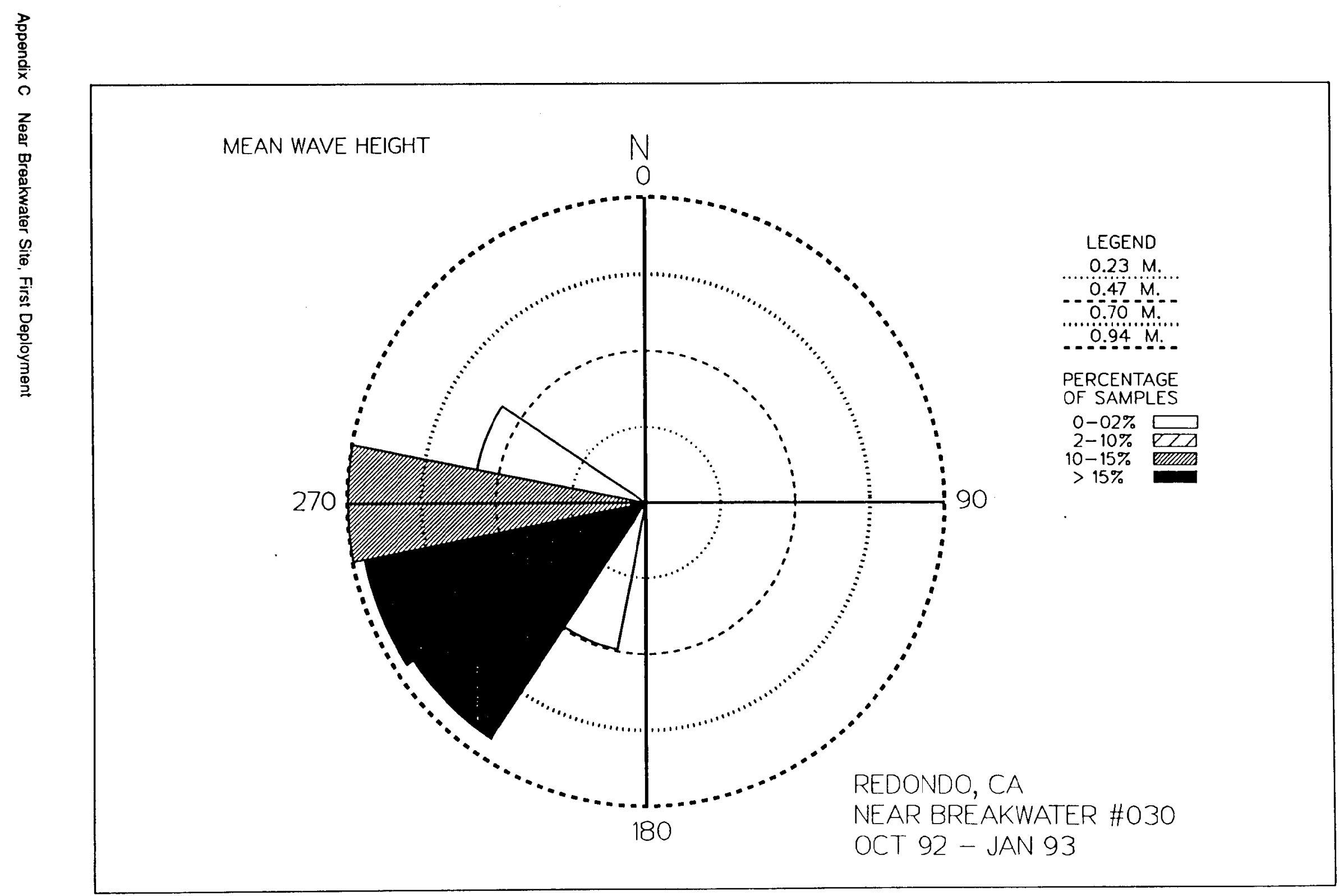




\section{Table C1}

Mean/Max Values for Near Breakwater (030)

First Deployment

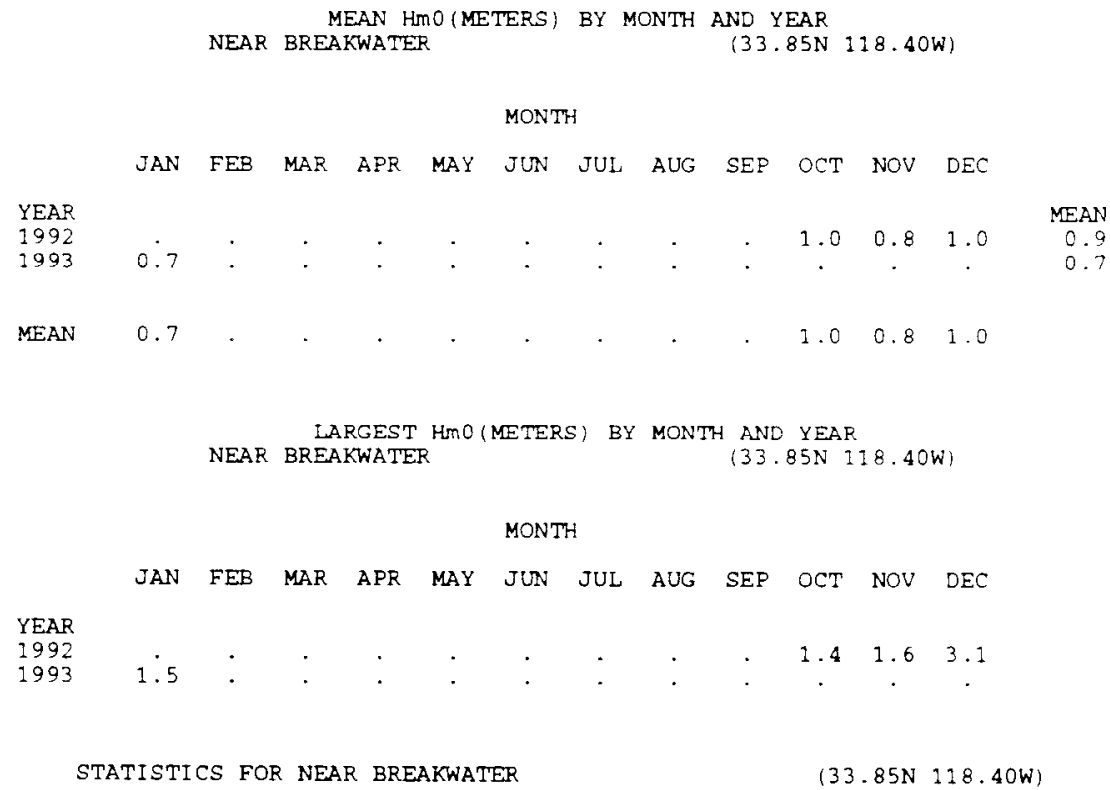

THE TP (SECONDS)ASSOC. WITH THE LARGEST HMO=

THE PEAK DIRECTION (DEGREES) ASSOC. WITH THE LARGEST HMO= 
Table C2

Percent Occurrence for Near Breakwater(030)

First Deployment

NEA.R BREAKWATEF

$33.95 \mathrm{~N} 128.40 \mathrm{~W}$

IRRESPEITIVE OF DIRECIION

OCTOBER 1992 - JANUARY 1993

PFRCENT OCRURRFNCE (XIOO) OF HFICHT AND PERIOD

HEI GHT (METERS)

PEAK PERIOD (SECONOS)

TOTAL

SHOKIER - 4.6- 3.6- 8.0- $70.7-72.6-32.8-74.2-26.6-34.4-$

4.5 5.6 $8.0 \quad 10.6 \quad 11.6 \quad 72.7$ 14.1 15.9 18.2 LONGER

$0.0-0$.

$0.5-0.9$

$1.0-1.4$

$1.5-1.9$

$2 \cdot 0-2 \cdot 4$

$=3 \cdot 0-3 \cdot 4$

$3 \cdot 0-3 \cdot 4$

$4.0-4.4$

$4.5-4.9$

$5.0+$

TOTAL

$\begin{array}{rrr}i 15 & 28 \\ 11 & 57 & 590\end{array}$

60127

$\begin{array}{rrrr}254 & 694 & 335 & =-\end{array}$

. $\quad 3$

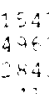

$381 \quad 62$

MEAN $\operatorname{HMO}(M)=0$.

LARGEST HMO $(M)=3.1$

MEAN TP (SEC) - 12.3

TOTAL CASES =

804 


\section{Appendix D South Breakwater Site, First Deployment}


SOUTH BREAKWATER

GAGE \#153

$33.84 N 118.40 \mathrm{~W}$
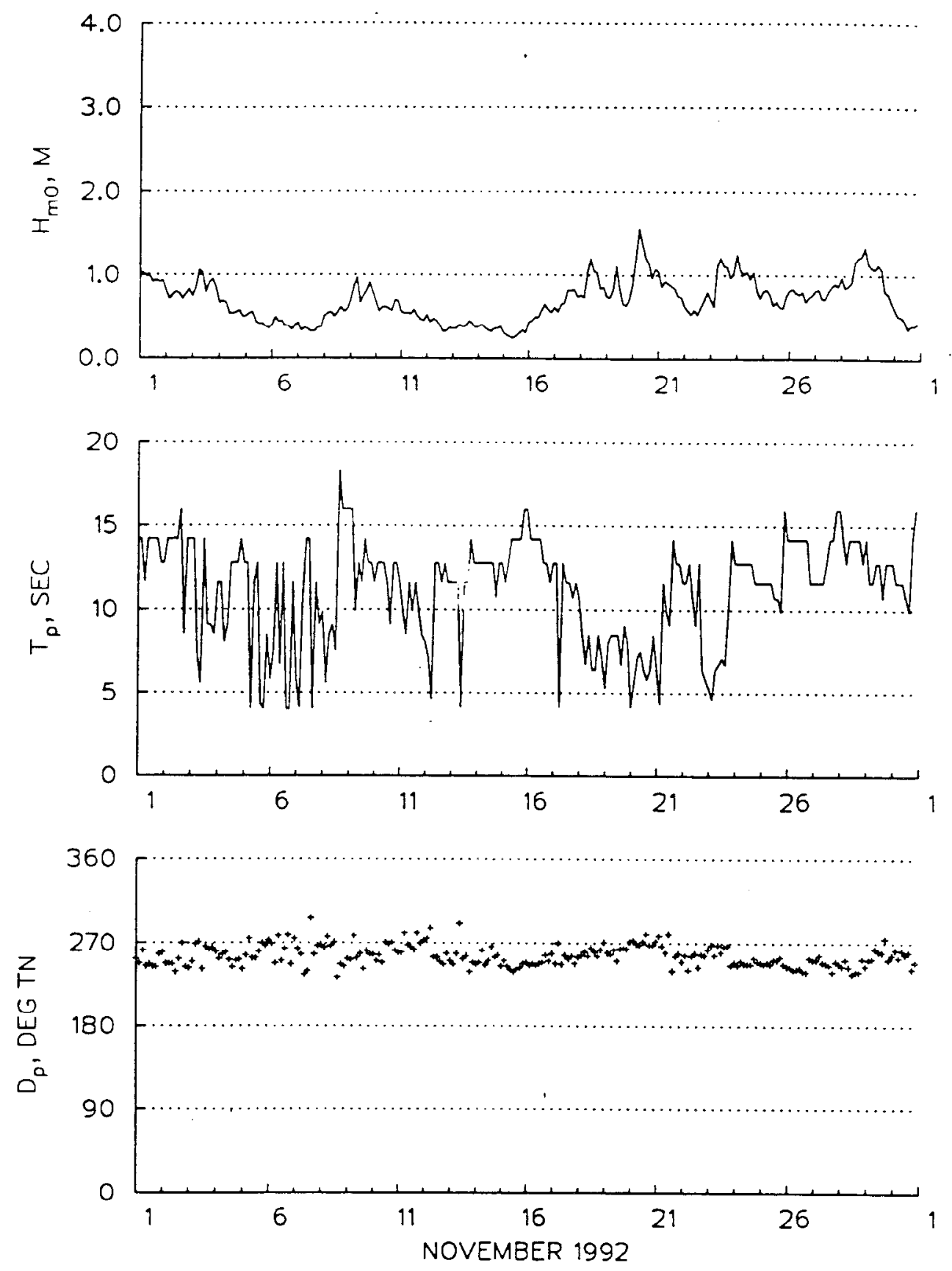

Figure D1. Time series plot for South Breakwater gage (153), November 1992, first deployment

D2 
SOUTH BREAKWATER

GAGE $\$ 53$

$33.84 \mathrm{~N} 118.40 \mathrm{~W}$
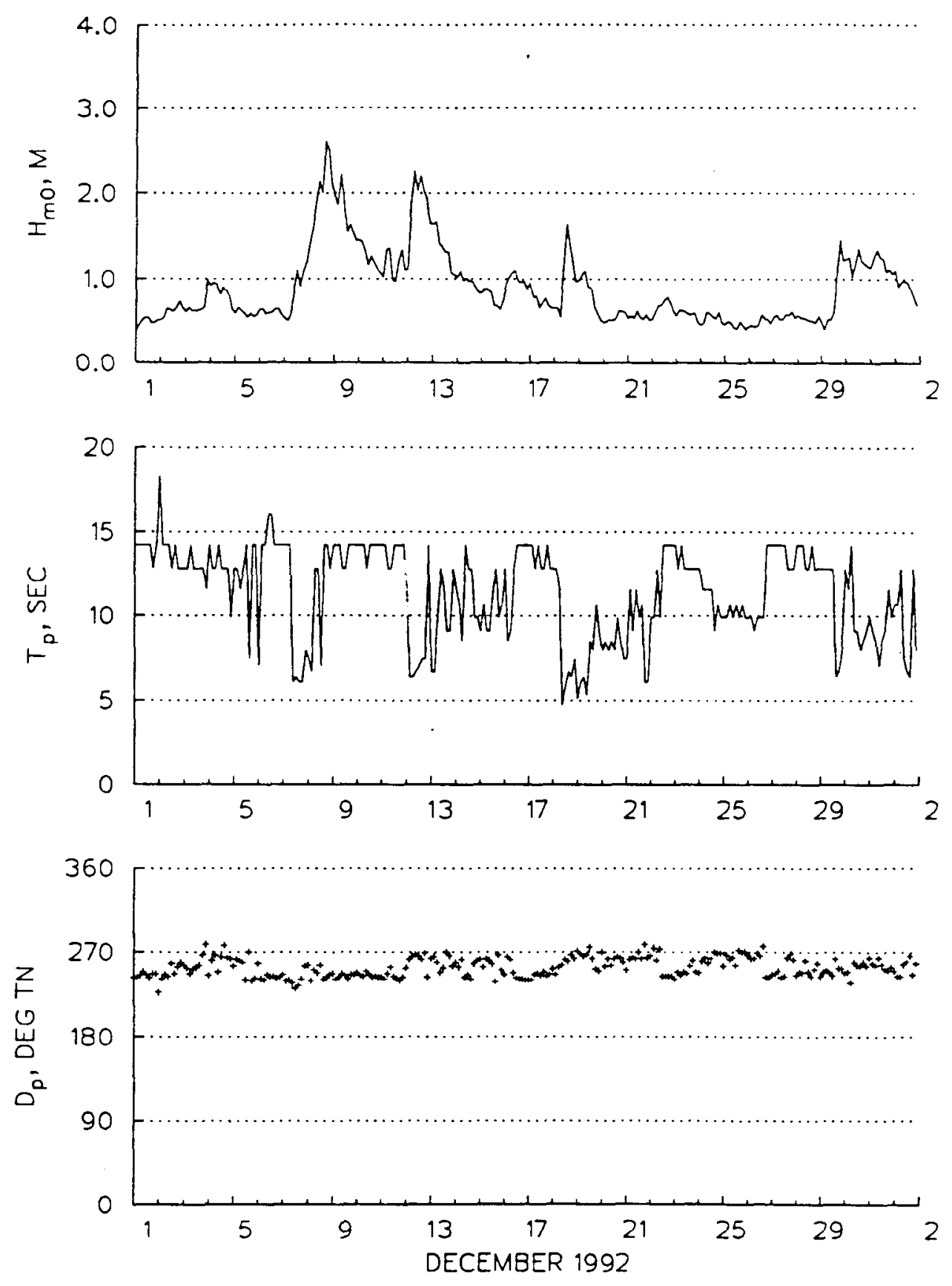

Figure D2. Time series for South Breakwater gage (153), December 1992, first deployment 
SOUTH BREAKWATER

GAGE \#153

$33.84 \mathrm{~N} 118.40 \mathrm{~W}$
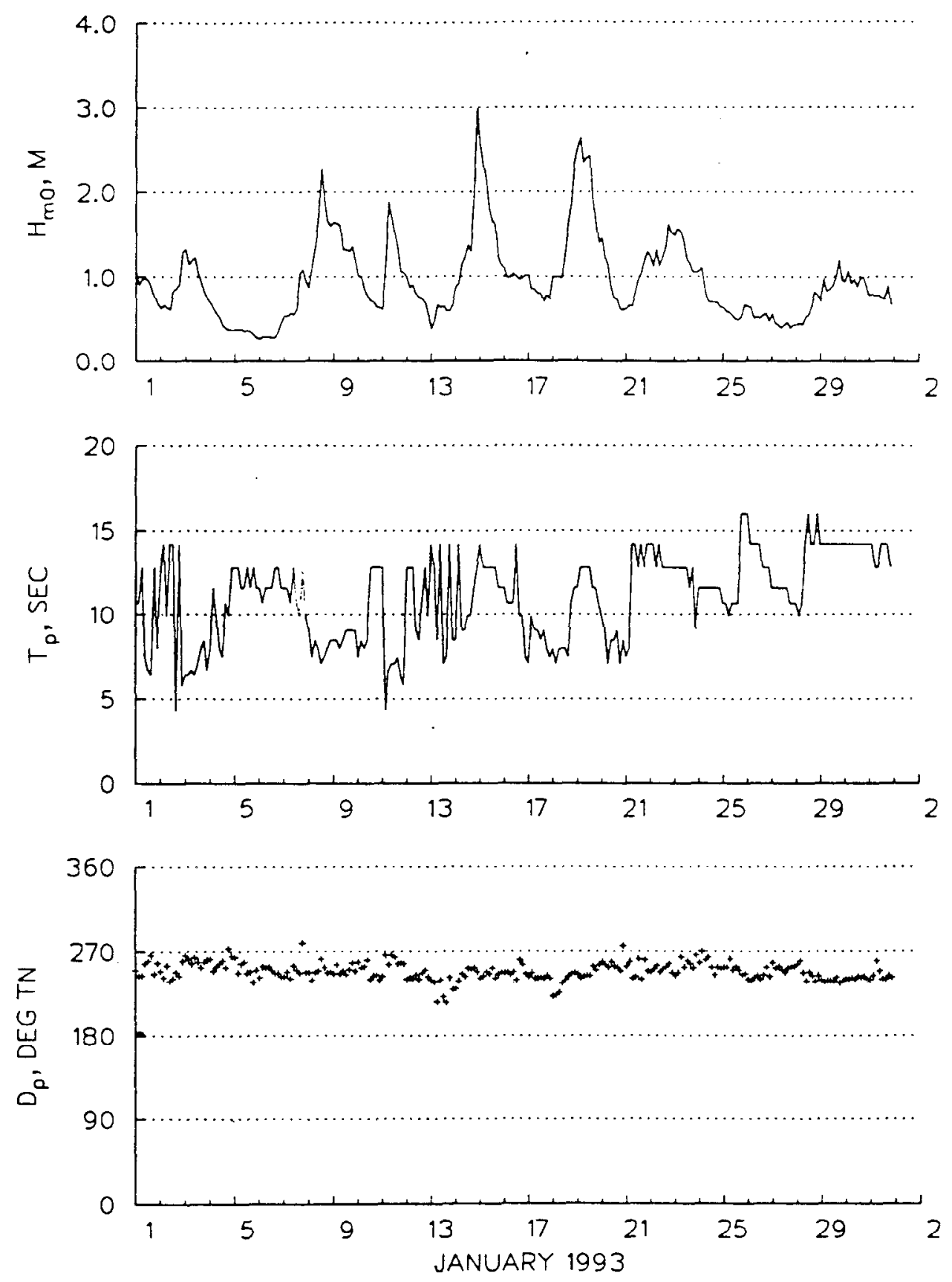

Figure D3. Time series plot for South Breakwater gage (153), January 1993, first deployment 


\section{SOUTH BREAKWATER}

GAGE \#153

$33.84 \mathrm{~N} 118.40 \mathrm{~W}$
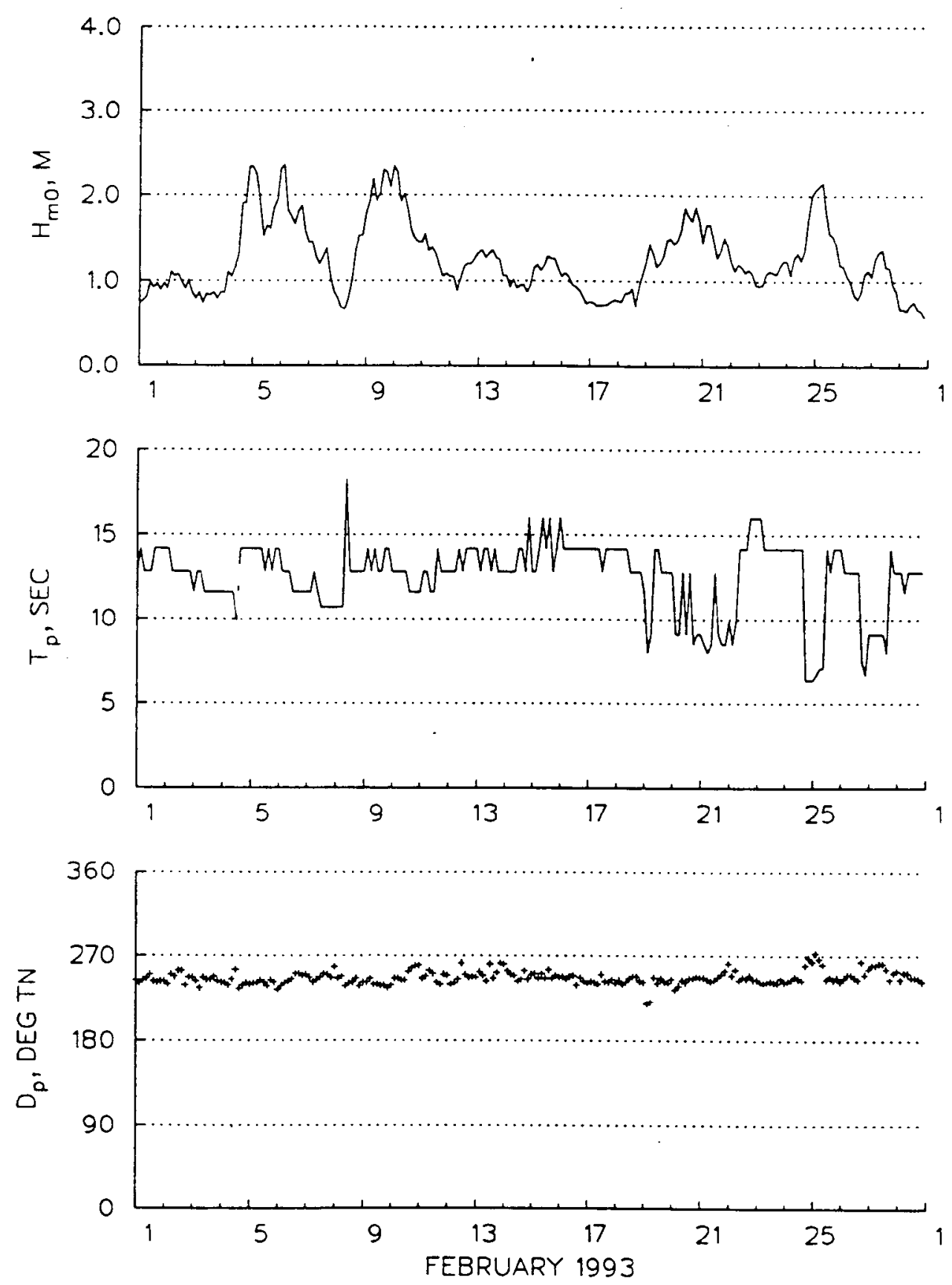

Figure D4. Time series for South Breakwater gage (153), February 1993, tirst deployment 
SOUTH BREAKWATER

GAGE \#153

$33.84 \mathrm{~N} 118.40 \mathrm{~W}$
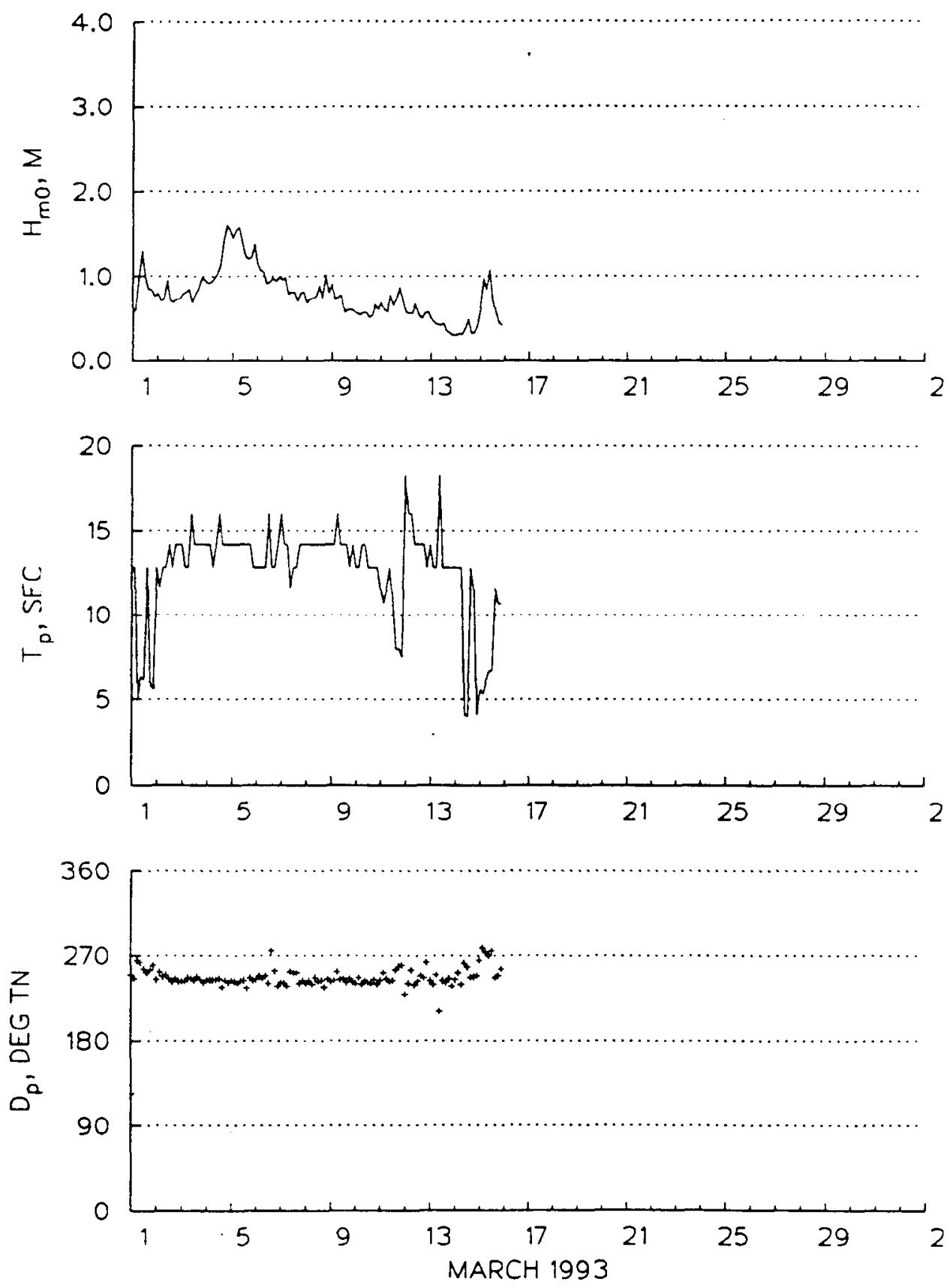

Figure D5. Time series for South Breakwater gage (153), March 1993, first deployment 


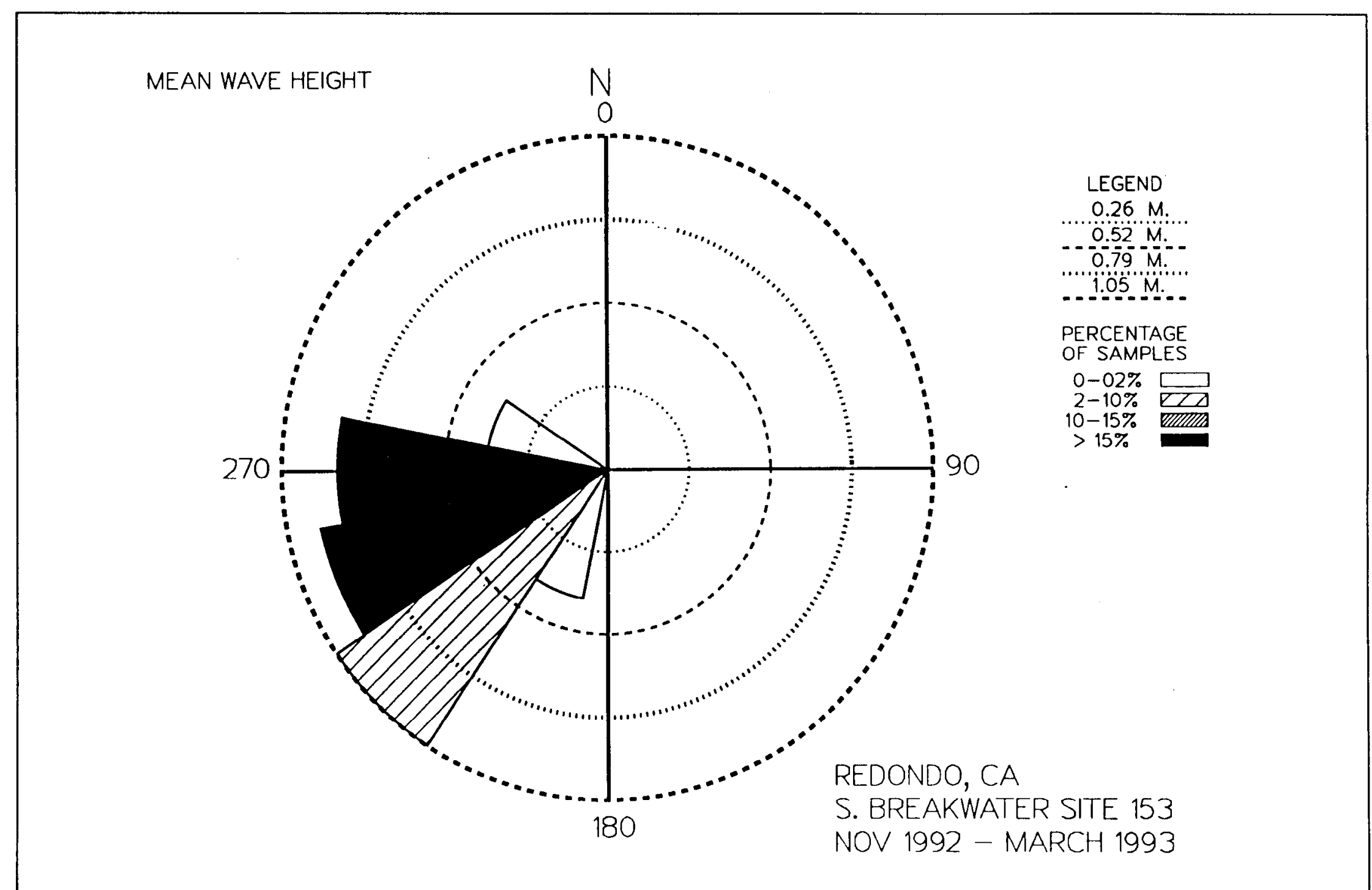


Table D1

Mean/Max Values for South Breakwater (153)

First Deployment

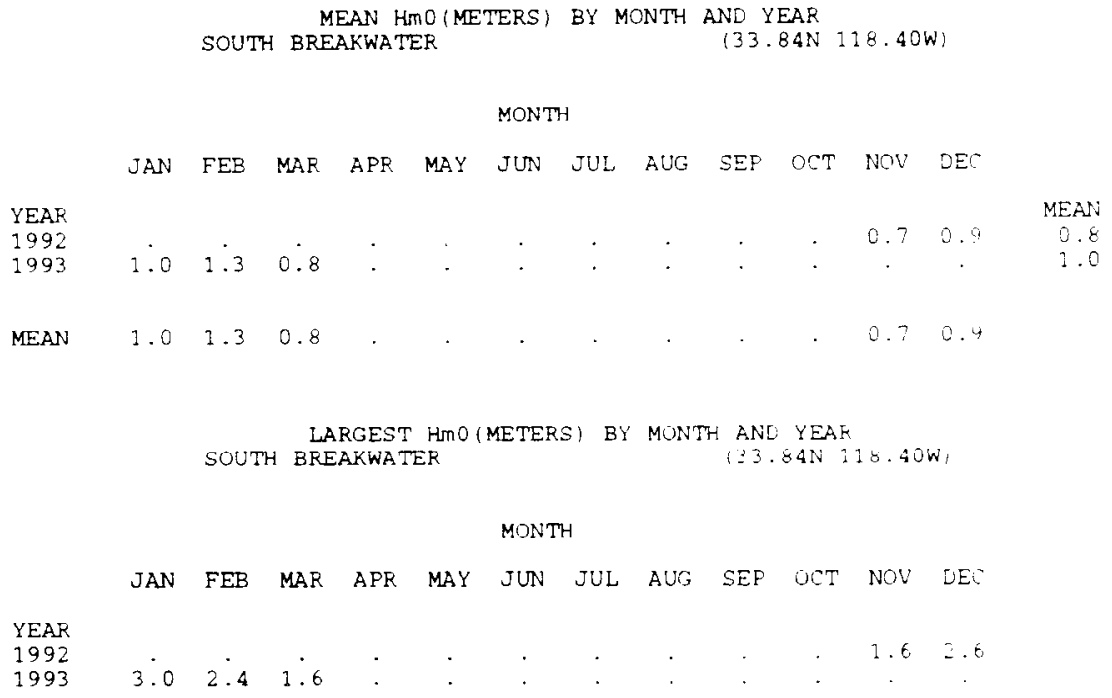

THE MOST FREQUENT 22.5 (CENTER) DIRECTION BAND (DEGREES) =

THE TP(SECONDS)ASSOC. WITH THE LARGEST HMO=

THE PEAK DIRECTION (DEGREES) ASSOC. WITH THE LARGEST HMO= 


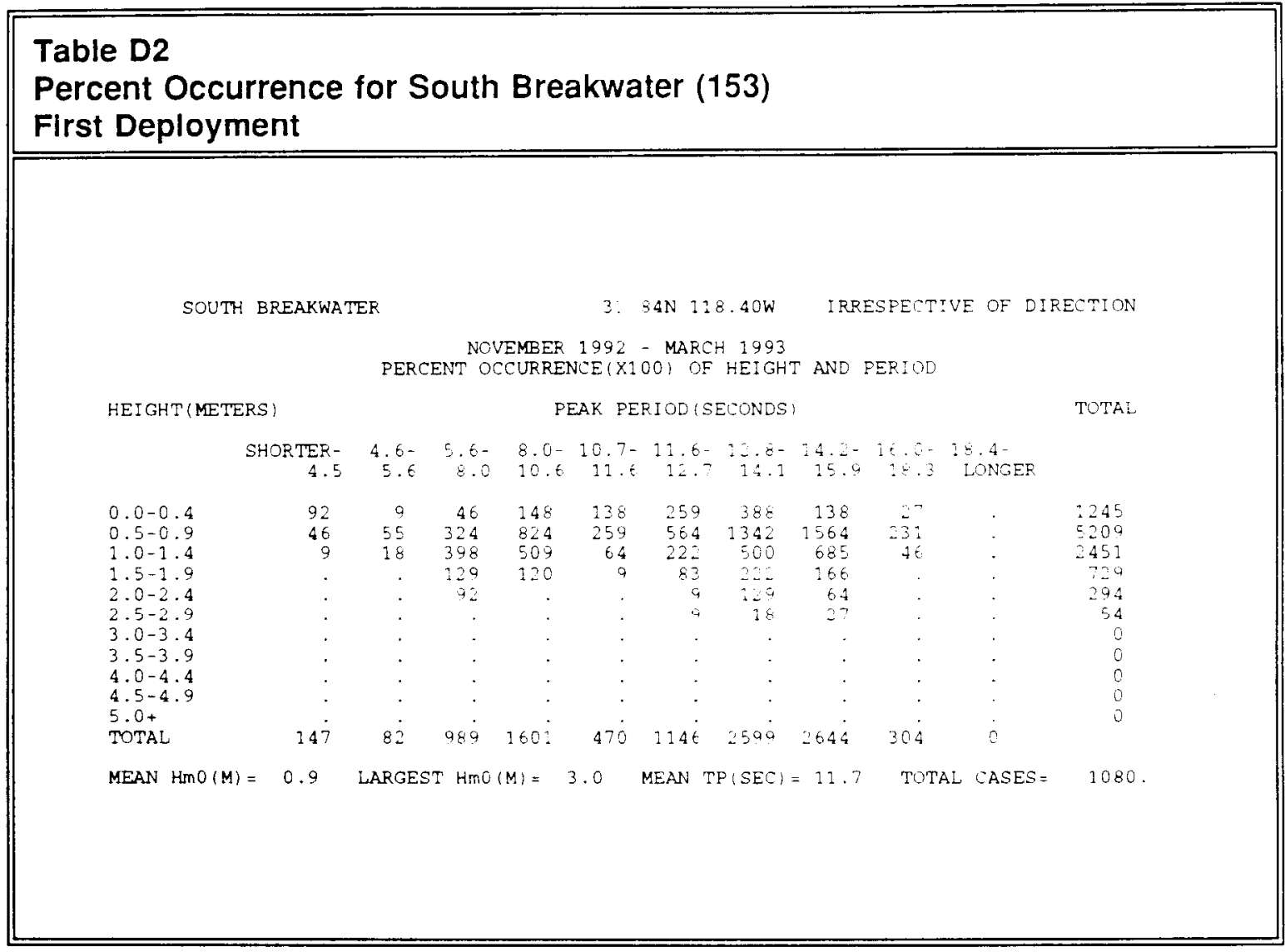




\section{Appendix E \\ Canyon Site, First Deployment}




\section{CANYON}

GAGE \#RB5

$33.83 \mathrm{~N} 118.40 \mathrm{~W}$
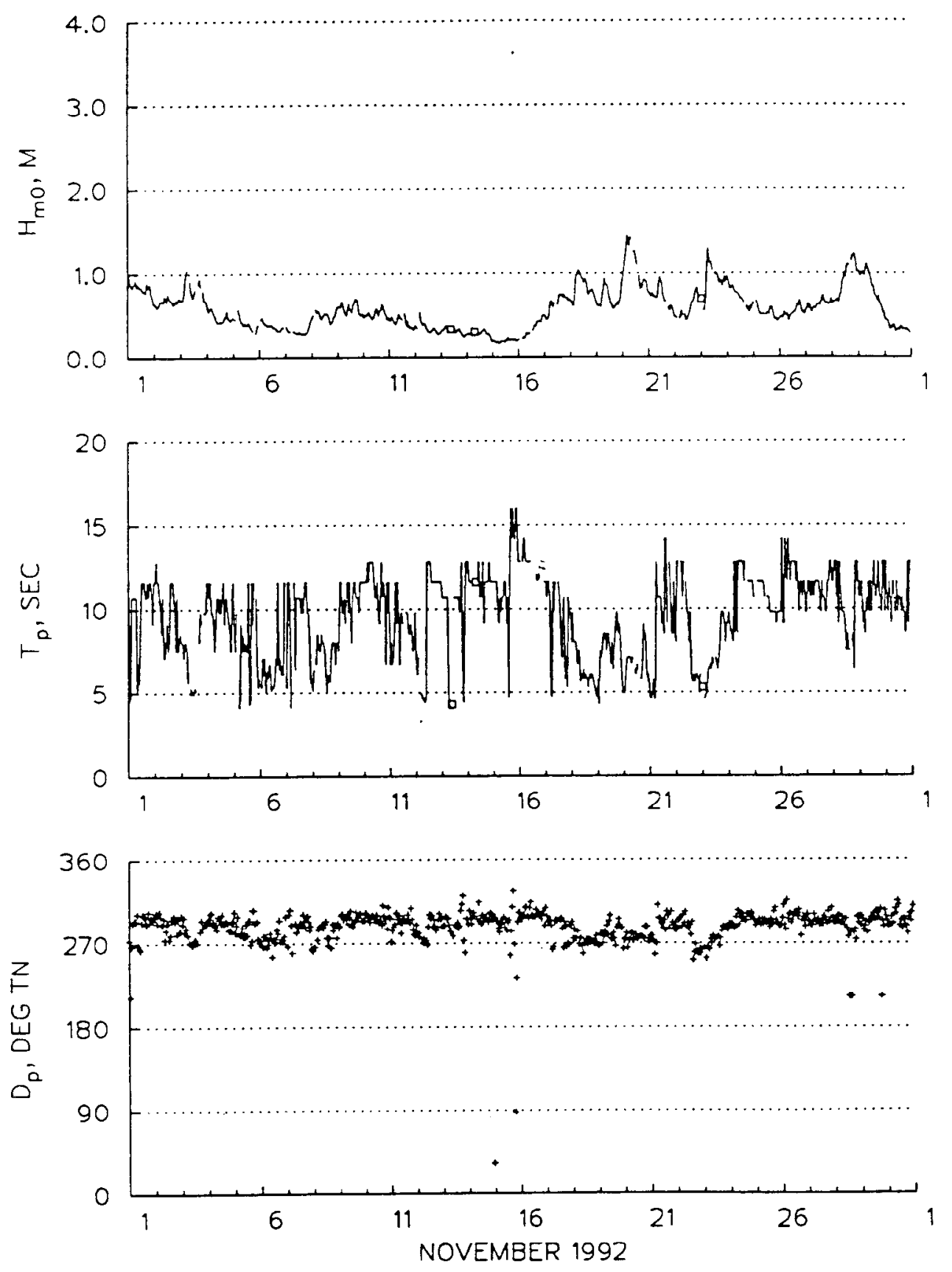

Figure E1. Time series plot for Canyon gage (RB5), November 1992, first deployment 
CANYON

GAGE \#RB5

$33.83 \mathrm{~N} 118.40 \mathrm{~W}$
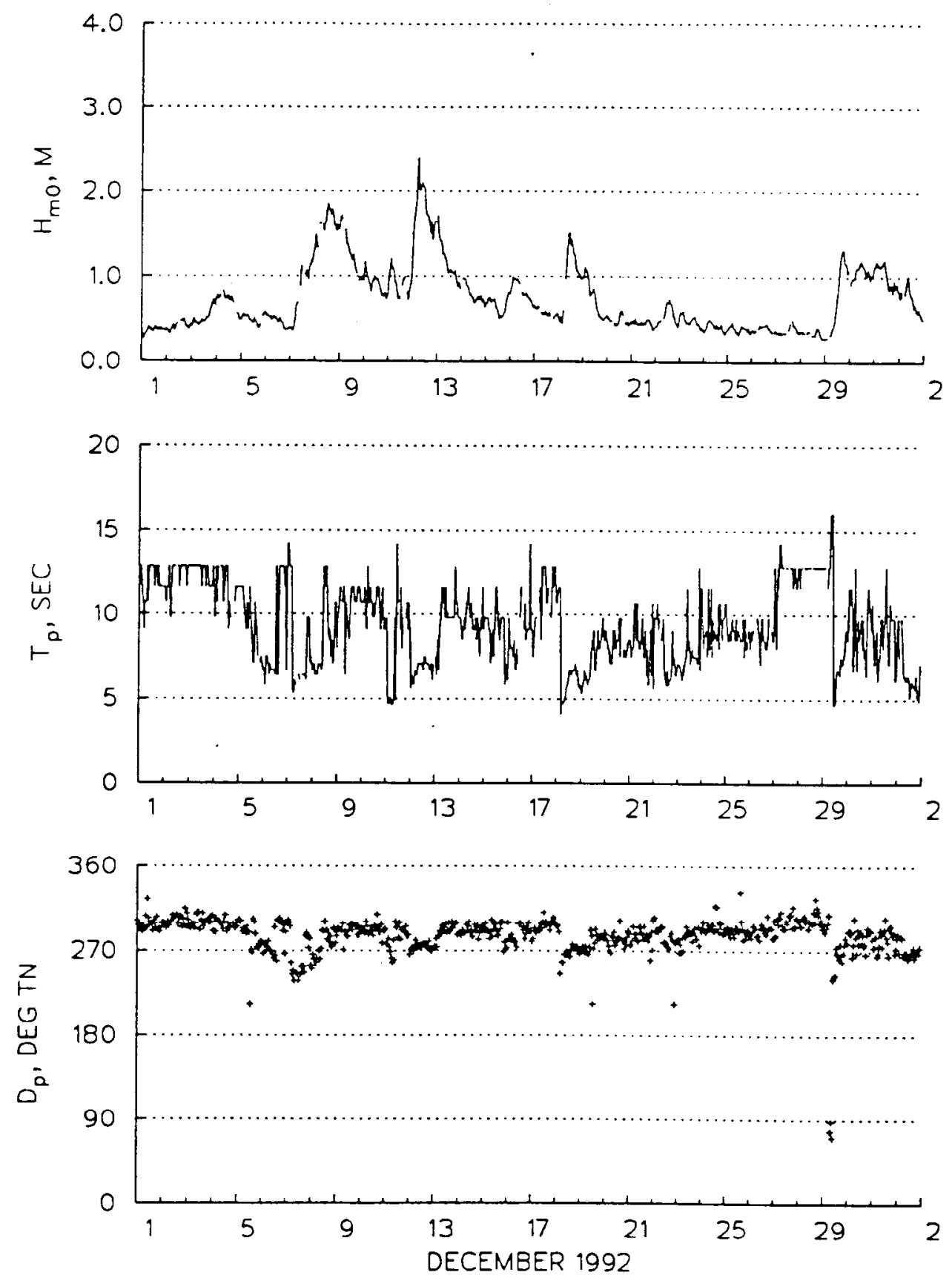

Figure E2. Time series plot for Canyon gage (RB5), December 1992, first deployment 


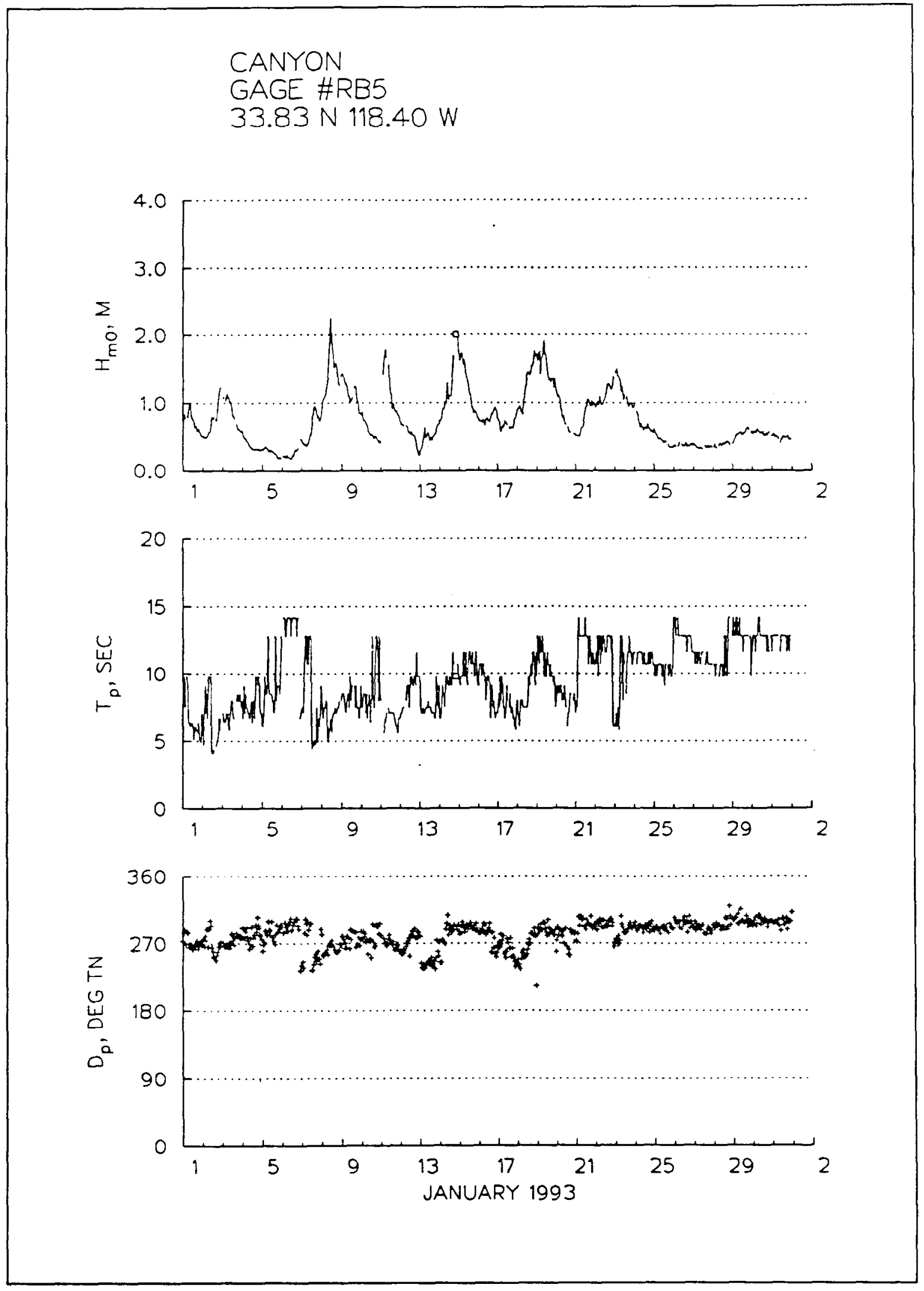

Figure E3. Time series plot for Canyon gage (RB5), January 1993, first deployment E4 


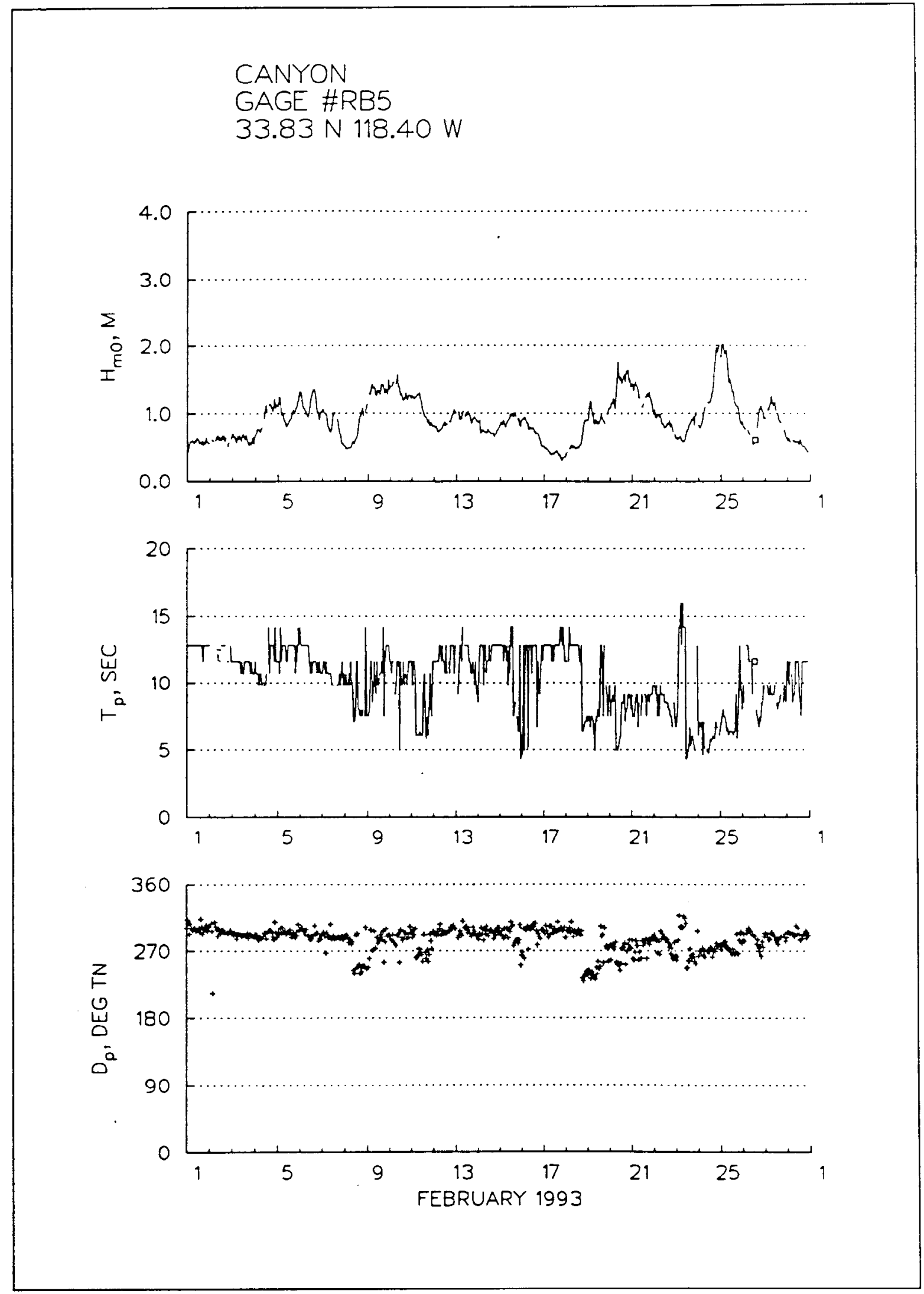

Figure E4. Time series plot for Canyon gage (RB5), February 1993, first deployment 
CANYON

GAGE \#RB5

$33.83 \mathrm{~N} 118.40 \mathrm{~W}$
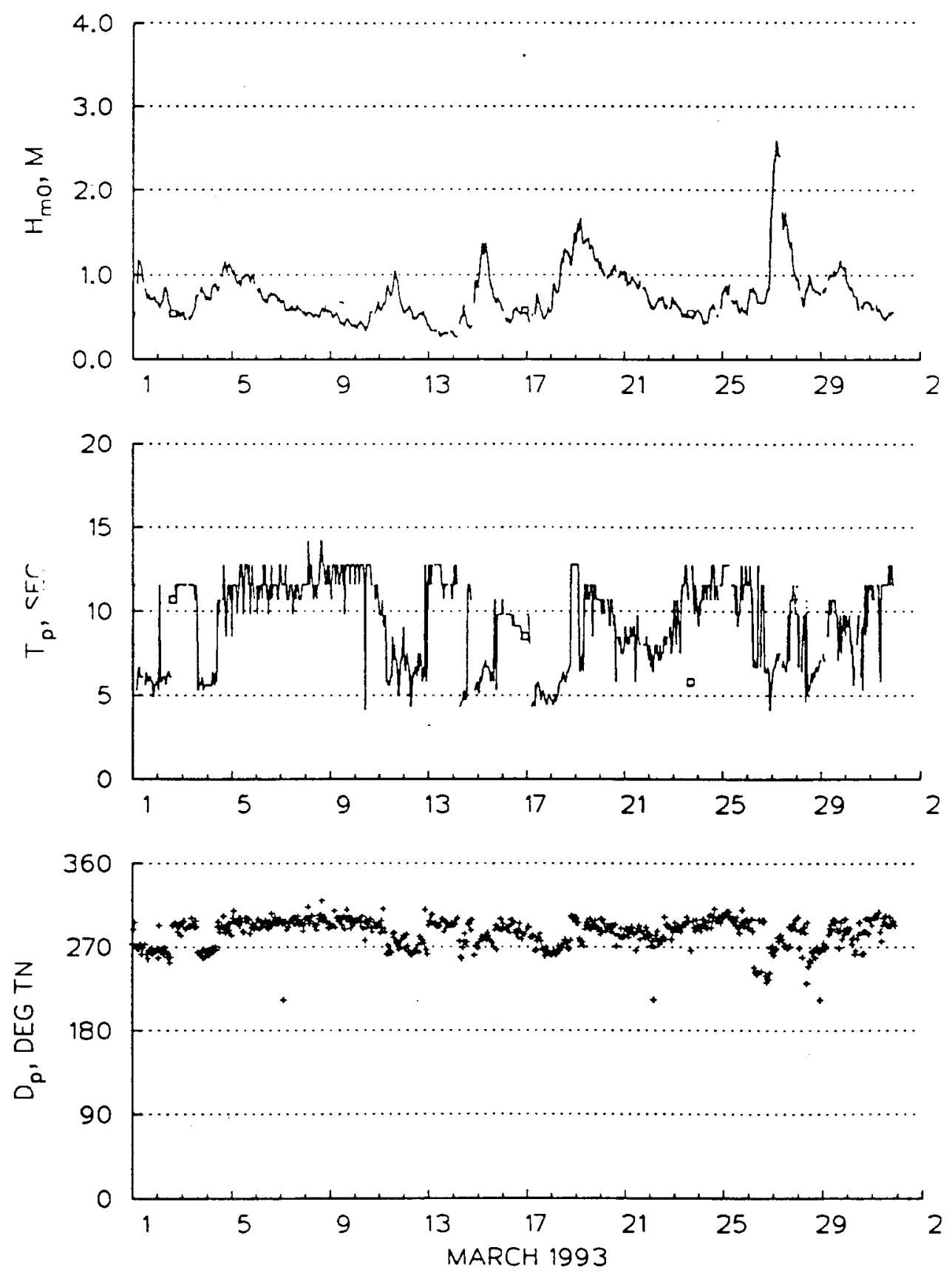

Figure E5. Time series plot for Canyon gage (RB5), March 1993, first deployment 


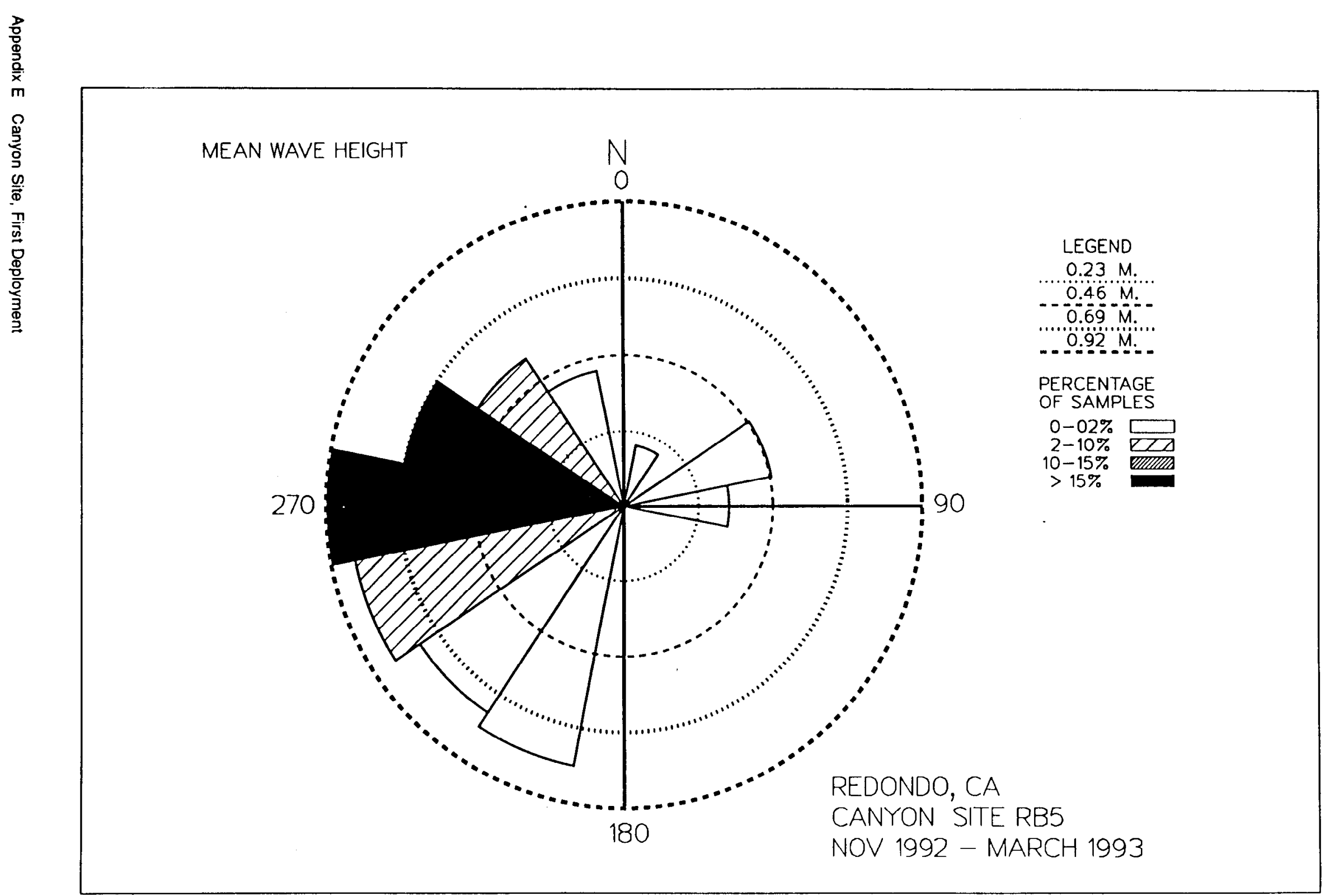




\section{Table E1}

Mean/Max Values for Canyon (RB5)

First Deployment

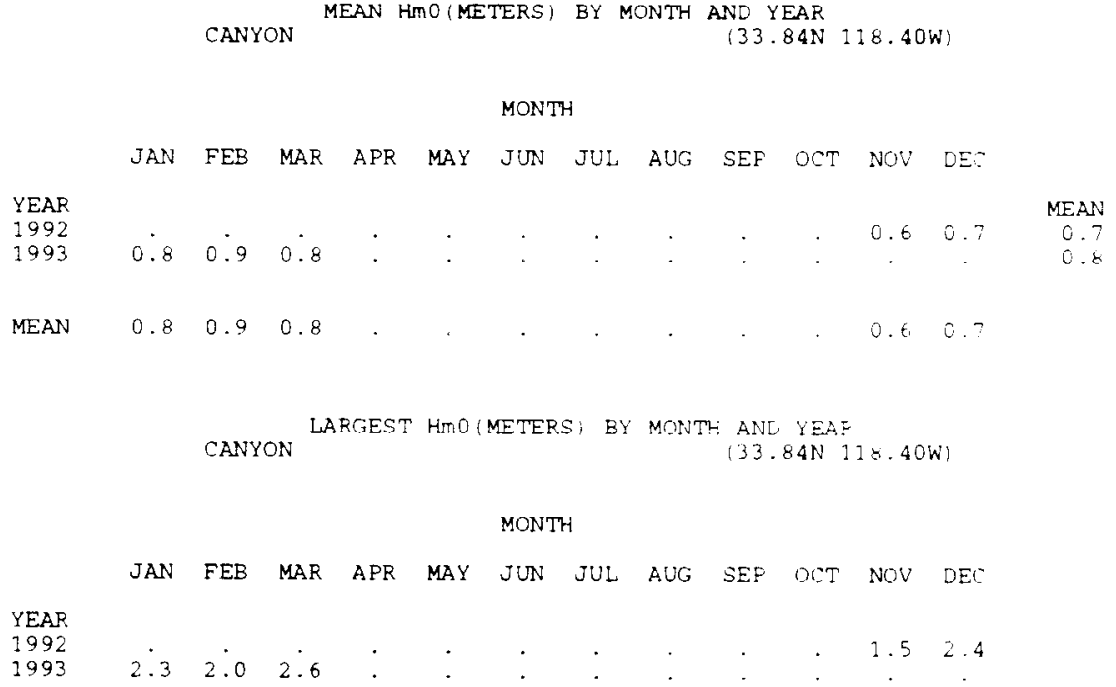

THE PEAK DIRECTION (DEGREES) ASSOC. WITH THE LARGEST HMO= 
Table E2

Percent Occurrence for Canyon (RB5)

First Deployment

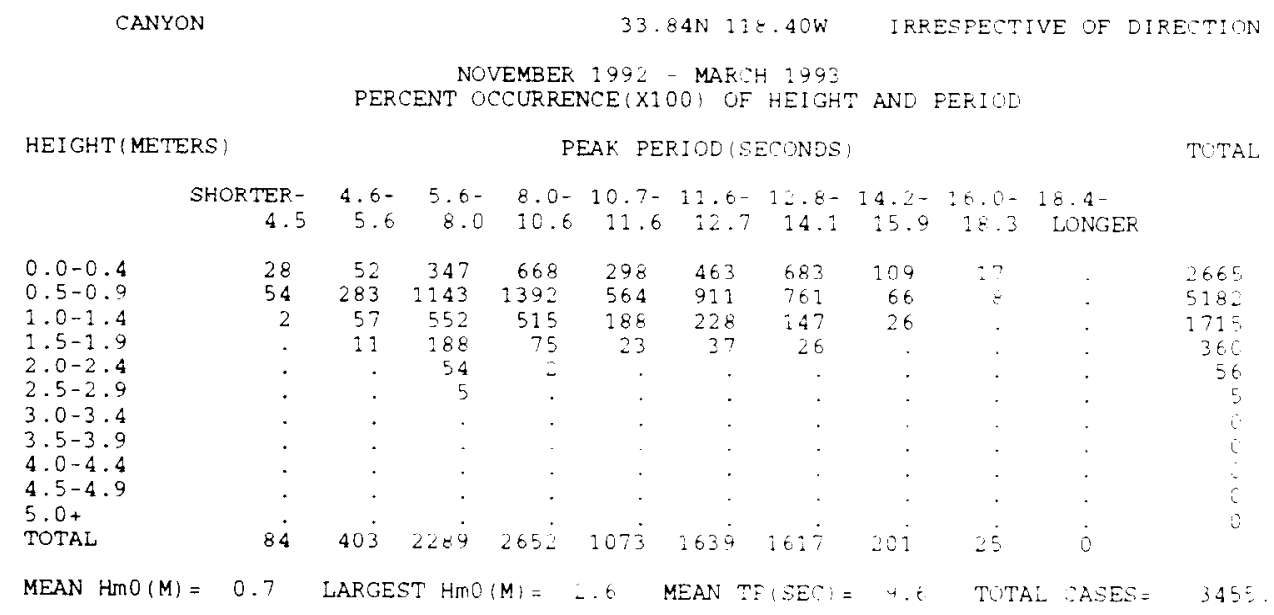




\section{Appendix F Redondo Site, First Deployment}


REDONDO

NDBC 46045

$33.84 \mathrm{~N}, 118.45 \mathrm{~W}$
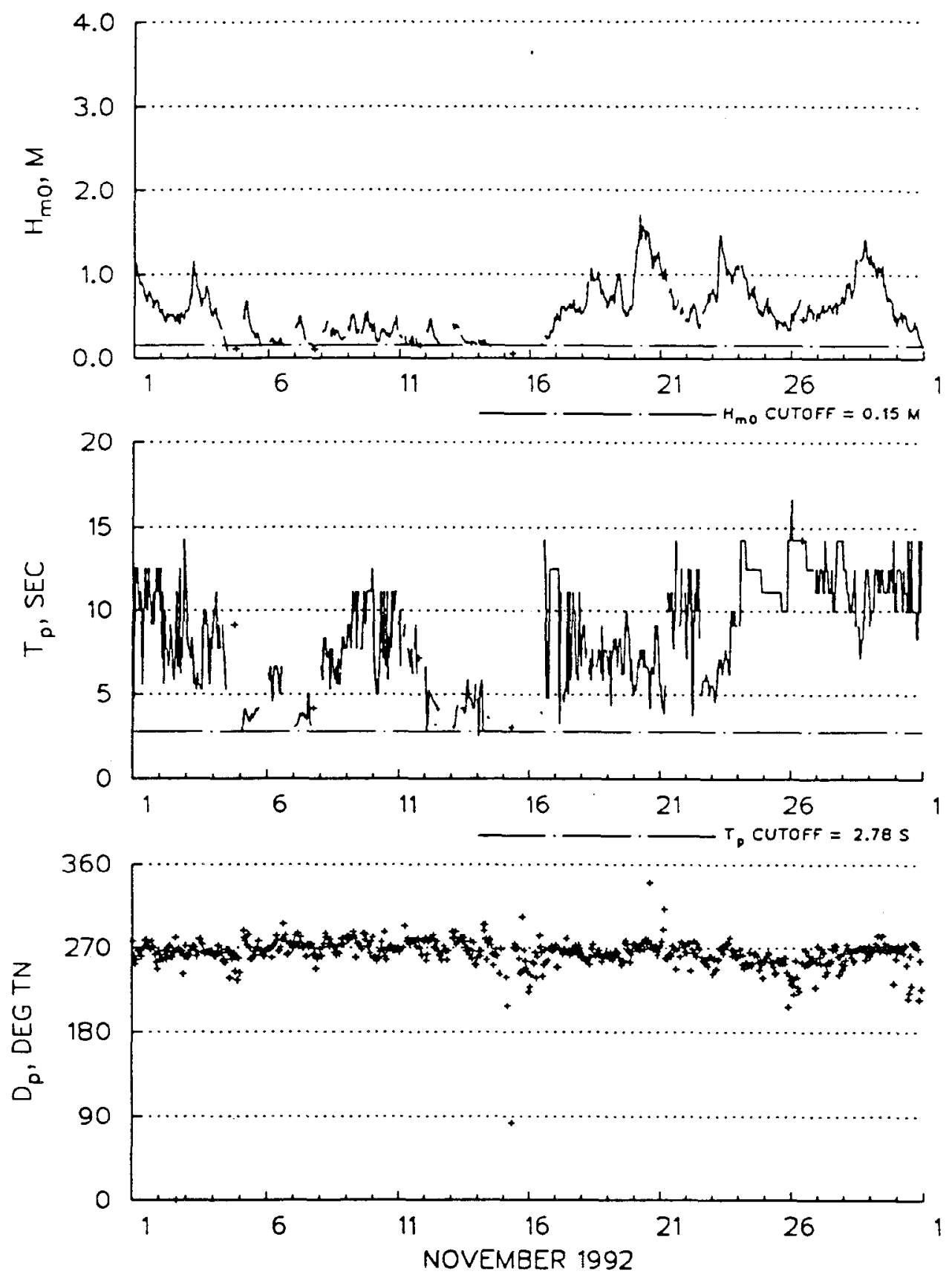

Figure F1. Time series plot for Redondo gage (NDBC 46045), November 1992, first deployment 


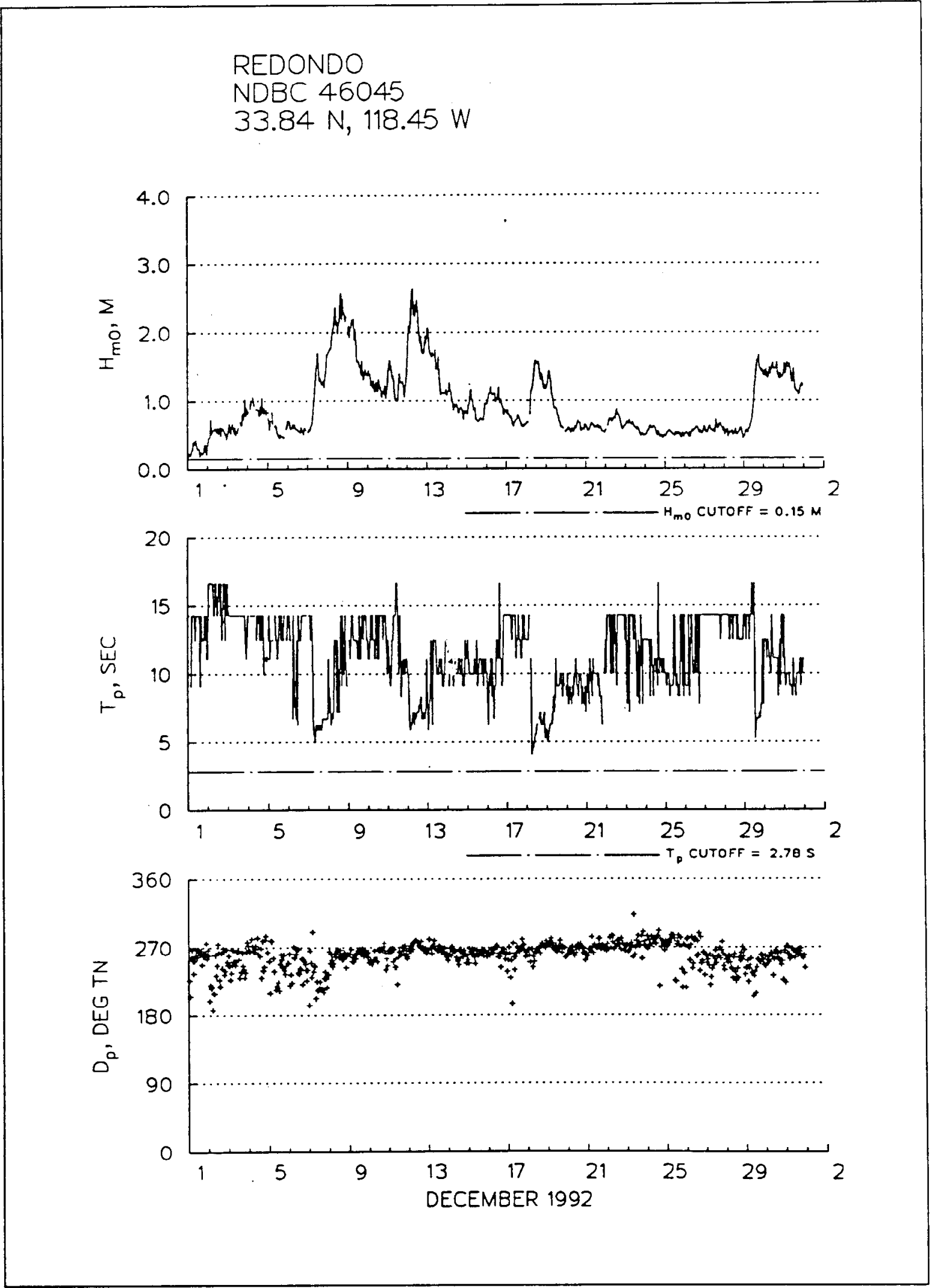

Figure F2. Time series plot for Redondo gage (NDBC 46045), December 1992, first deployment 
REDONDO

NDBC 46045

$33.84 \mathrm{~N}, 118.45 \mathrm{~W}$
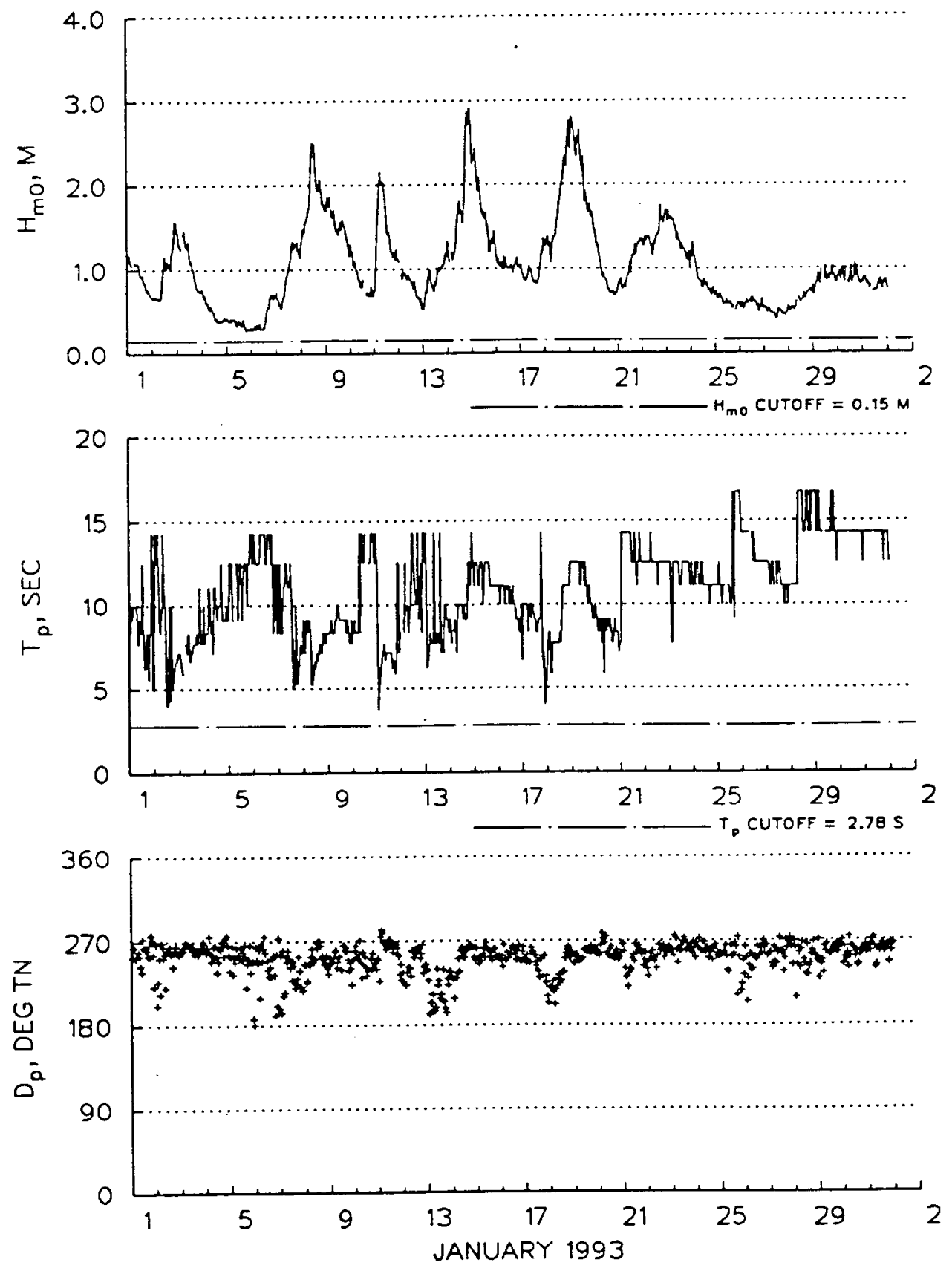

Figure F3. Time series plot for Redondo gage (NDBC 46045), January 1993, first deployment 


\section{REDONDO \\ NDBC 46045 \\ $33.84 \mathrm{~N}, 118.45 \mathrm{~W}$}
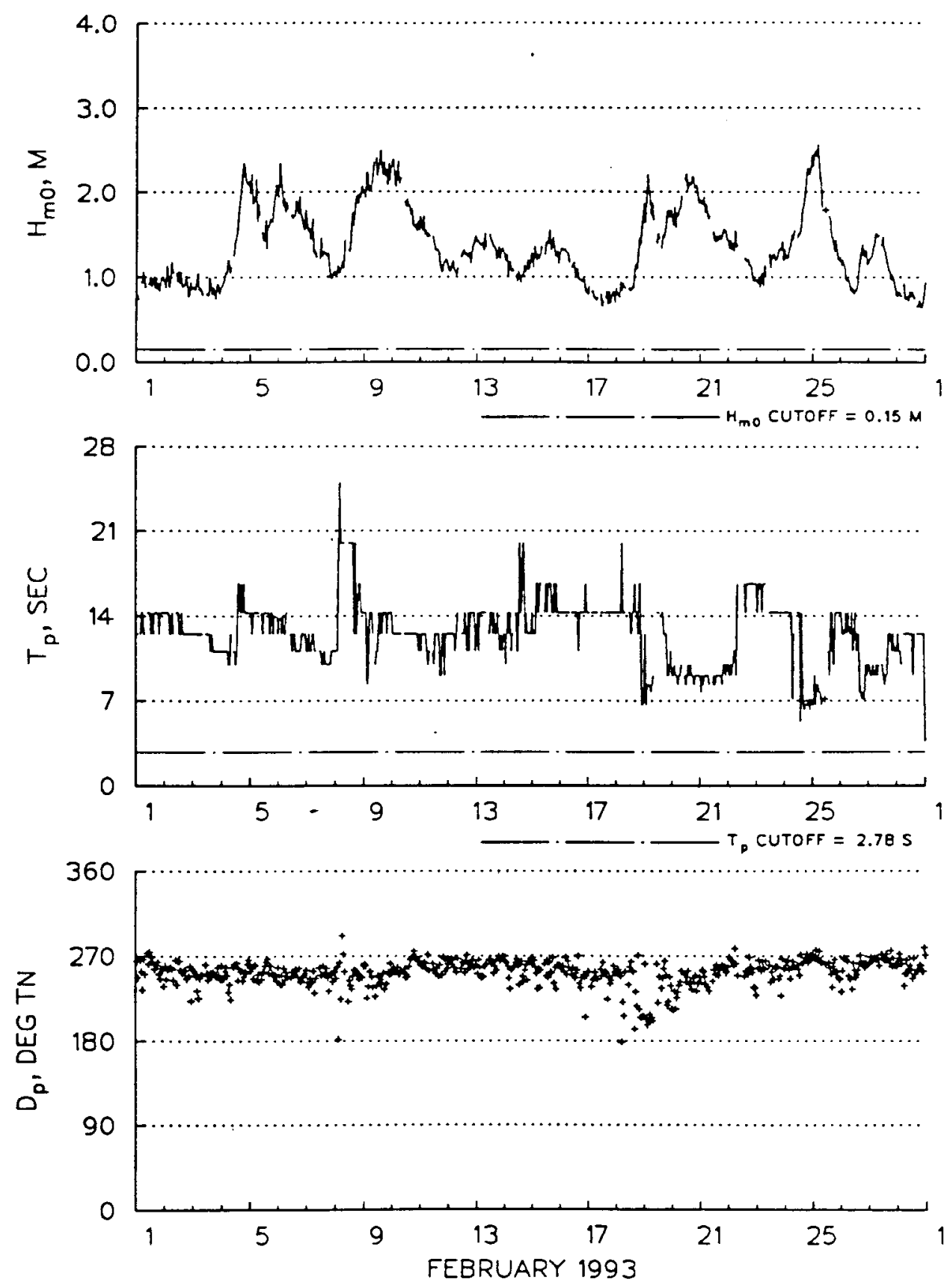

Figure F4. Time series plot for Redondo gage (NDBC 46045), February 1993, first deployment 


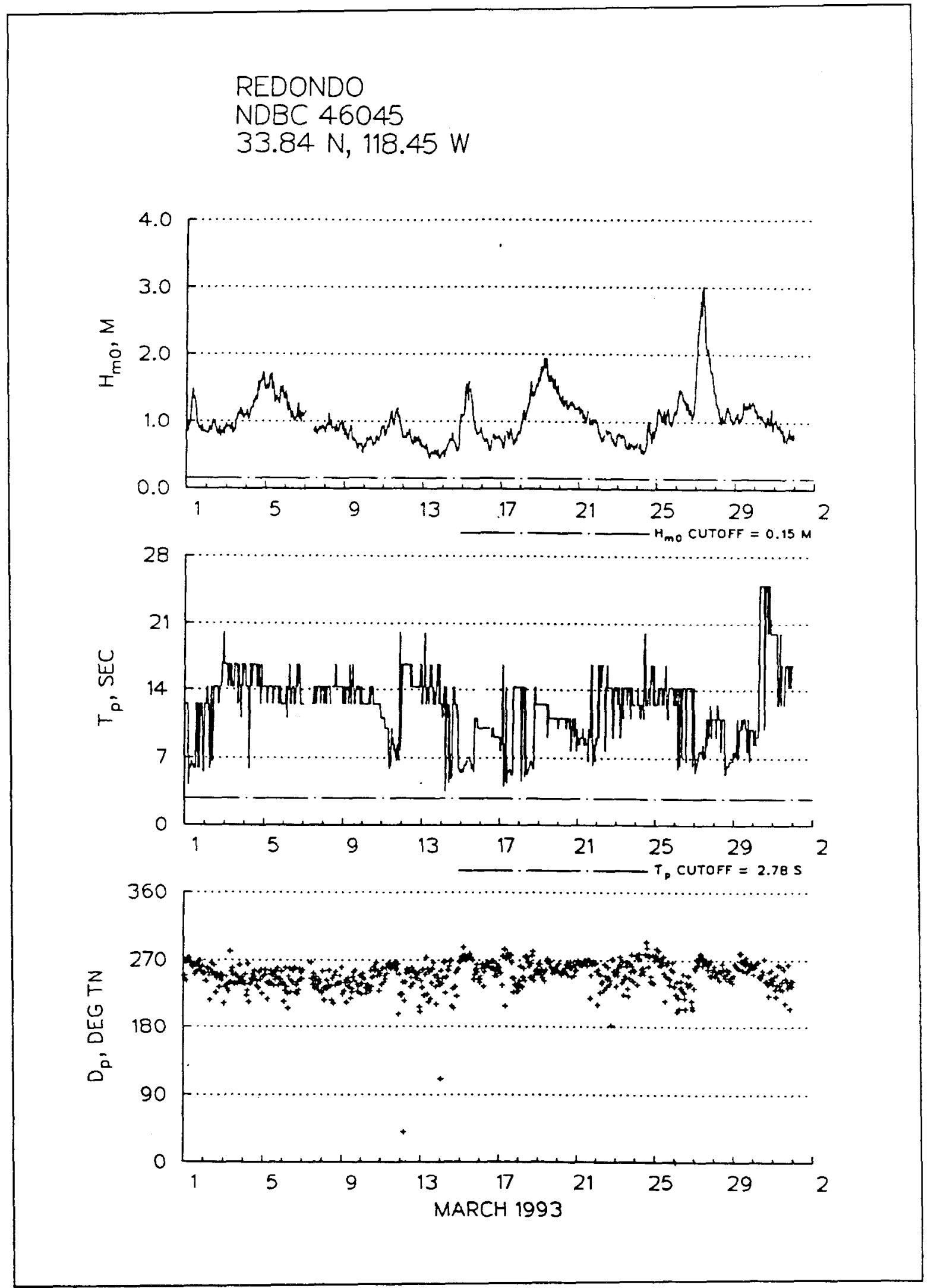

Figure F5. Time series plot for Redondo gage (NDBC 46045), March 1993, first deployment F6 


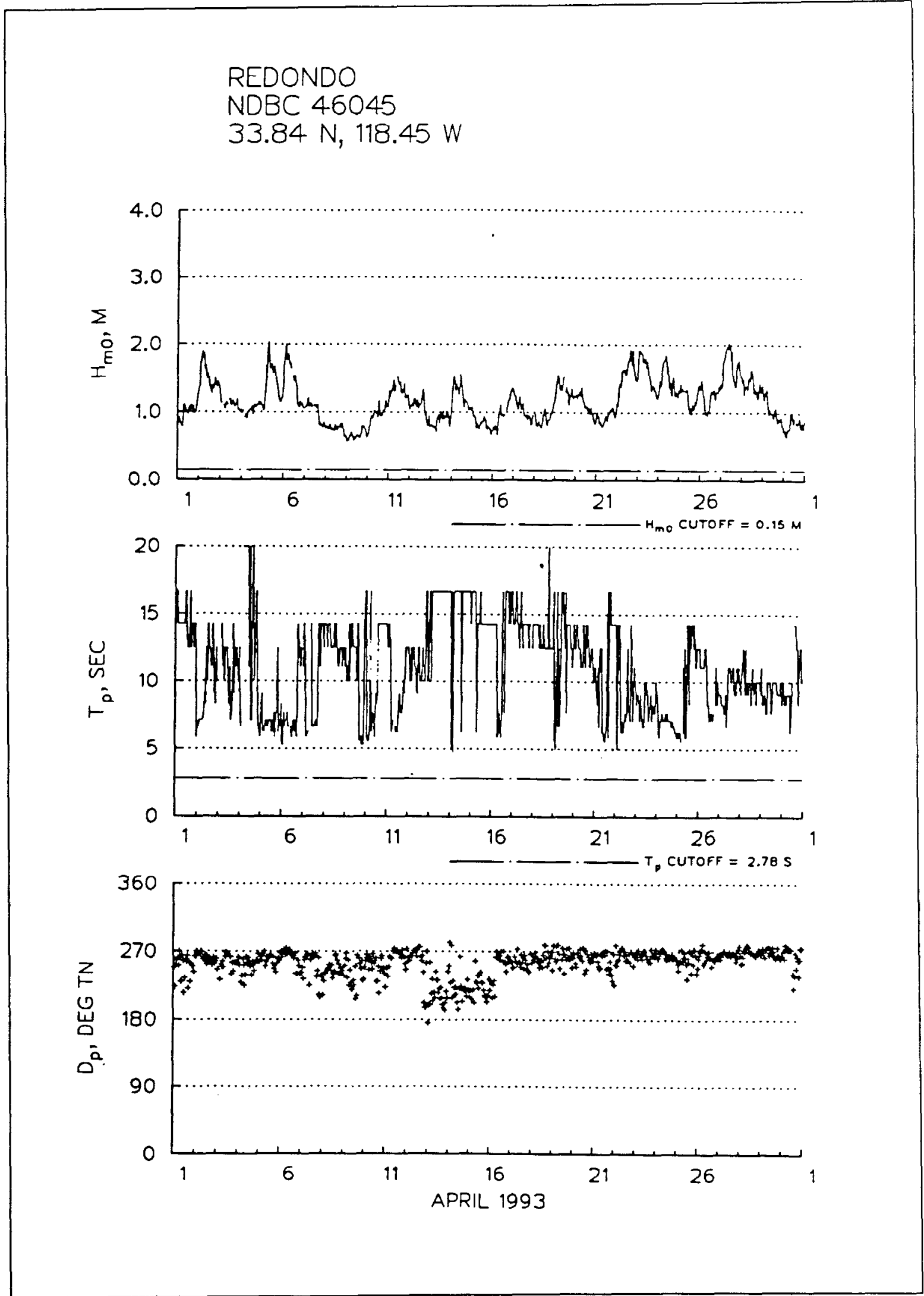

Figure F6. Time series plot for Redondo gage (NDBC 46045), April 1993, first deployment 


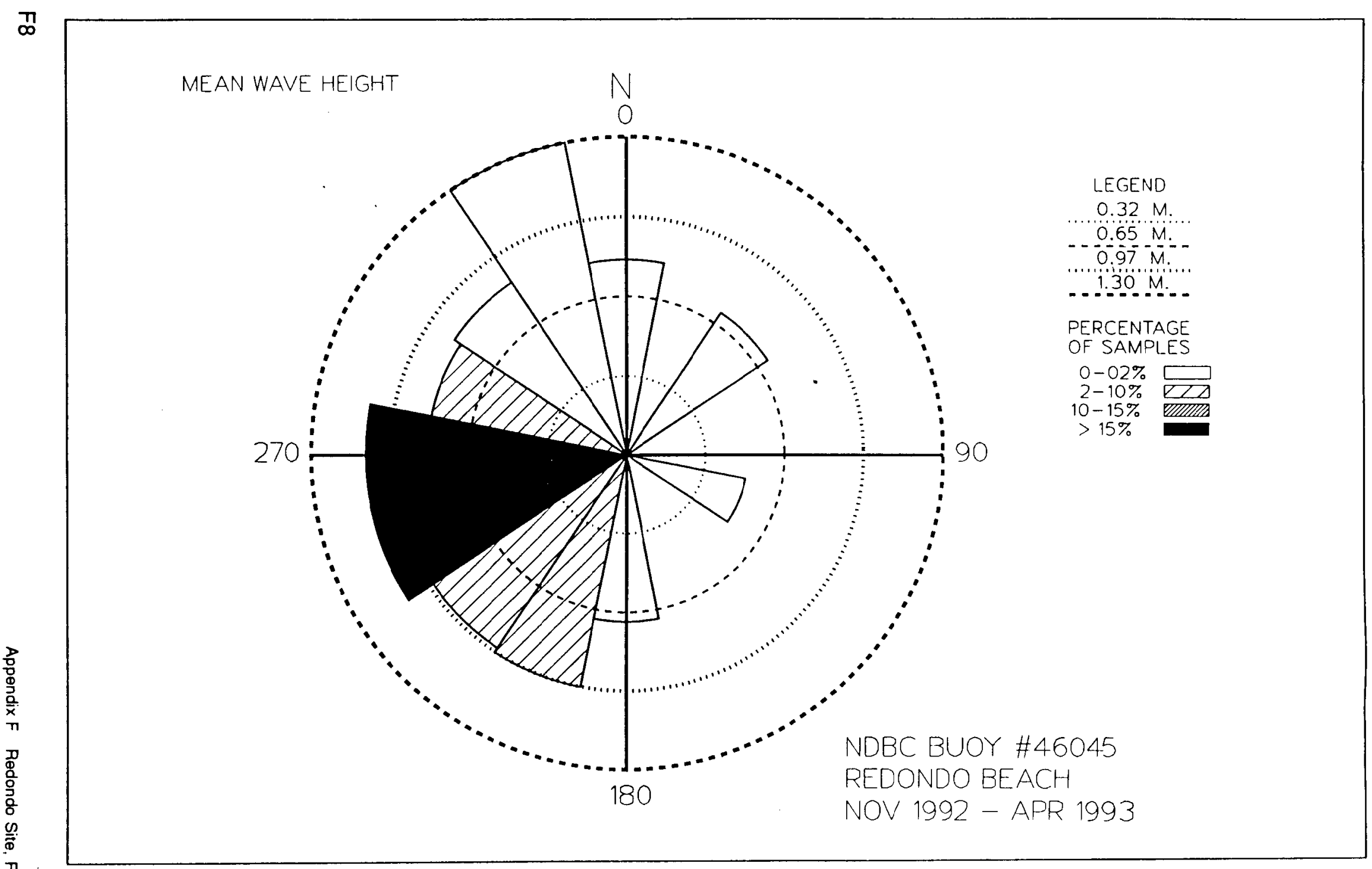

Figure F7. Wave rose plot for Redondo gage (NDBC 46045), first deployment 
Table F1

Mean/Max Values for Redondo (NDBC 46045)

First Deployment

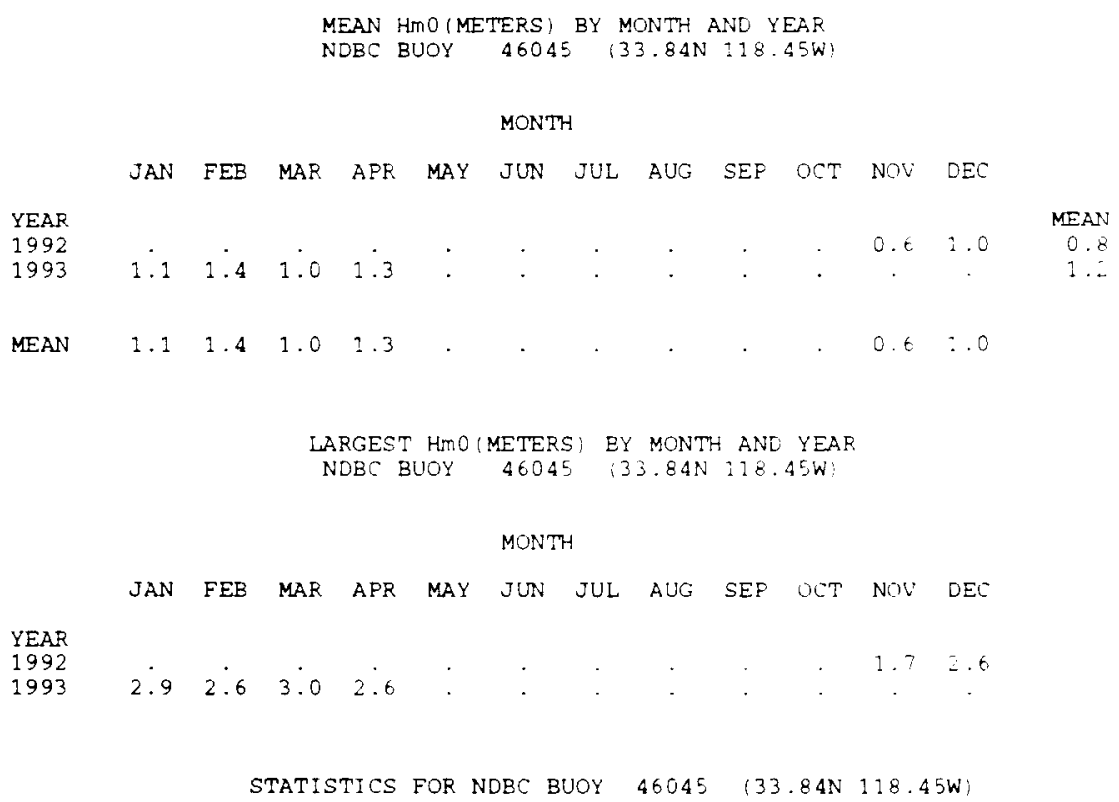

THE MEAN SIGNIFICANT WAVE HEIGHT(METERS) =

THE MEAN PEAK WAVE FERIOD (SECONDS) =

THE MOST FREQUENT 22.5 (CENTER) DIRECTION BAND (DEGREES) =

THE STANDARD DEVIATION OF HMO (METERS) =

THE STANDARD DEVIATION OF TP(SECONDS)=

THE LARGEST HMO (METERS) =

THE TP(SECONDS)ASSOC. WITH THE LARGEST HMO=

THE PEAK DIRECTION (DEGREES) ASSOC. WITH THE LARGEST HMO = 
Table F2

Percent Occurrence for Redondo (NDBC 46045)

First Deployment

BUOY STATION $46045 \quad 33.84 \mathrm{~N} 118.45 \mathrm{~W}$ FOR ALL DIRECTIONS NOVEMBER 1992 - APRIL 1993 PERCENT OCCURRENCE $(X 100)$ OF HEIGHT AND PERIOD

\begin{tabular}{|c|c|c|c|c|c|c|c|c|c|c|c|}
\hline \multirow[t]{2}{*}{ HEIGHT (METERS) } & \multicolumn{10}{|c|}{ PEAK PERIOD (SECONDS) } & \multirow[t]{2}{*}{ TOTAL } \\
\hline & $<6.9$ & $\begin{array}{r}6.9- \\
8.0\end{array}$ & $\begin{array}{r}8.1 . \\
8.7\end{array}$ & $\begin{array}{r}8.8- \\
9.5\end{array}$ & $\begin{array}{l}9.6- \\
10.5\end{array}$ & $\begin{array}{r}10.6- \\
11.7\end{array}$ & $\begin{array}{r}11.8- \\
13.3\end{array}$ & $\begin{array}{r}13.4- \\
15.3\end{array}$ & $\begin{array}{r}15.4 . \\
18.1\end{array}$ & $\begin{array}{l}18.2 \\
\text { LONGER }\end{array}$ & \\
\hline $0.0-0.9$ & 544 & 223 & 201 & 274 & 399 & 512 & 909 & 1331 & 291 & 36 & 4720 \\
\hline $1.0-1.9$ & 664 & 394 & 208 & 370 & 392 & 5,49 & 845 & 826 & $30 t$ & 98 & $4 E_{1}=$ \\
\hline $2.0-2.9$ & 90 & 125 & 31 & 34 & 24 & 58 & 142 & 102 & 7 & . & 613 \\
\hline $3.0-3.9$ & . & 2 & . & . & . & . & 2. & . & . & . & 2 \\
\hline $4.0-4.9$ & . & . & . & . & . & . & . & . & . & . & $\hat{C}$ \\
\hline $5.0-5.9$ & . & . & . & : & . & . & . & . & . & . & 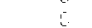 \\
\hline $6.0-6.9$ & . & . & . & . & . & . & . & . & . & . & 0 \\
\hline $7.0-7.9$ & . & . & . & . & . & . & . & . & . & & 0 \\
\hline 8.08 .9 & : & : & : & : & : & . & & : & . & . & 6 \\
\hline $9.0-9.9$ & . & . & . & . & & : & & & . & . & 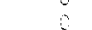 \\
\hline $10.0+$ & & & : & ${ }^{\circ}$ & & . & & . & . & 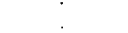 & j \\
\hline TOTAL & 1298 & 744 & 440 & 678 & 815 & 1119 & 1896 & 2259 & 604 & 134 & \\
\hline $\operatorname{MEAN} \operatorname{HmO}(M)=$ & 1.1 & LARGES & I Hnol & $M)=$ & .0 & MEAN I & $P(S E C)$ & $=11.2$ & TOTt & AL CASES = & 4079 \\
\hline
\end{tabular}




\section{Appendix G Catalina Ridge Site, First Deployment}




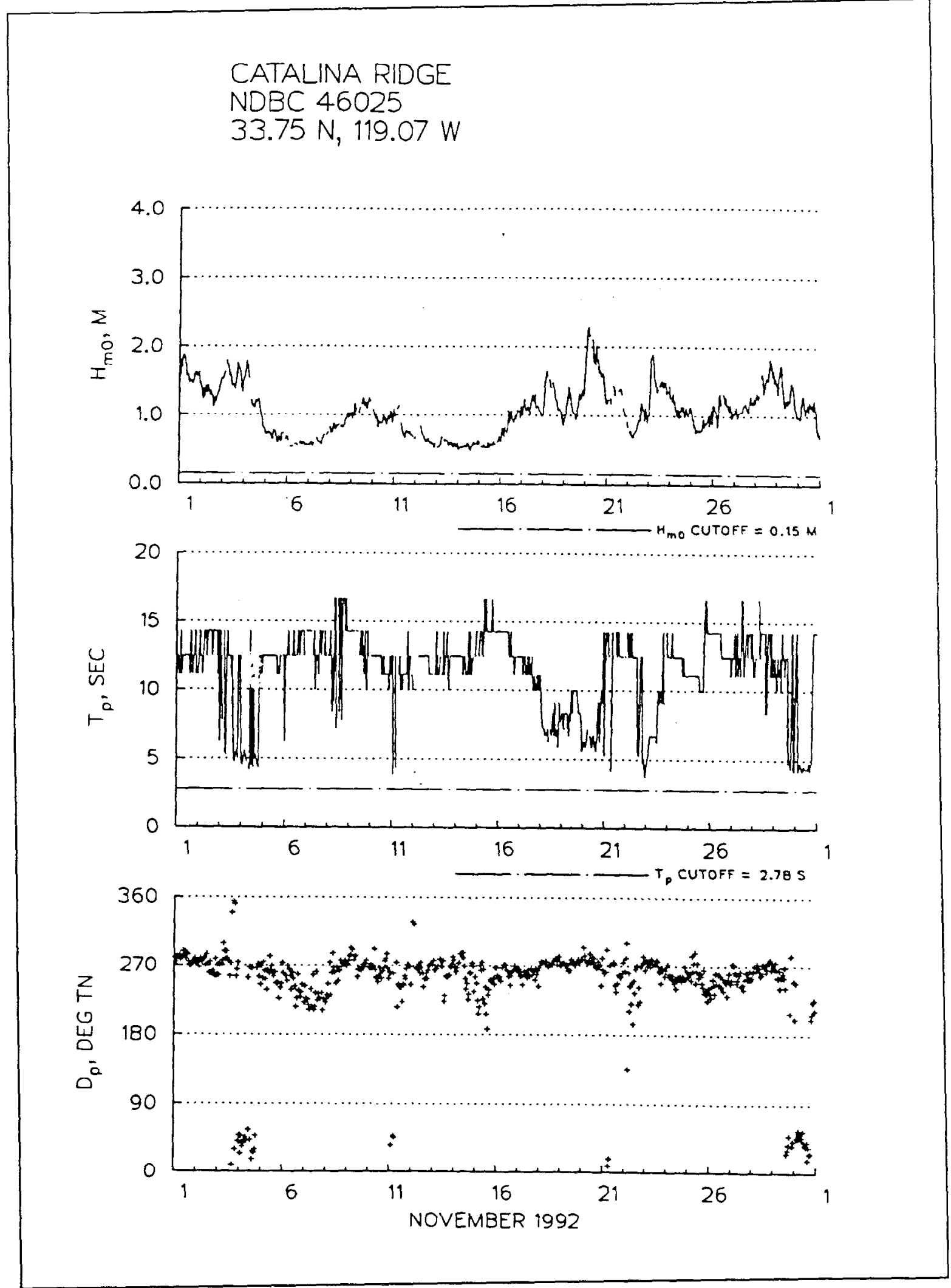

Figure G1. Time series plot for Catalina Ridge gage (46025), November 1992, first deployment 
CATALINA RIDGE

NDBC 46025

$33.75 \mathrm{~N}, 119.07 \mathrm{~W}$
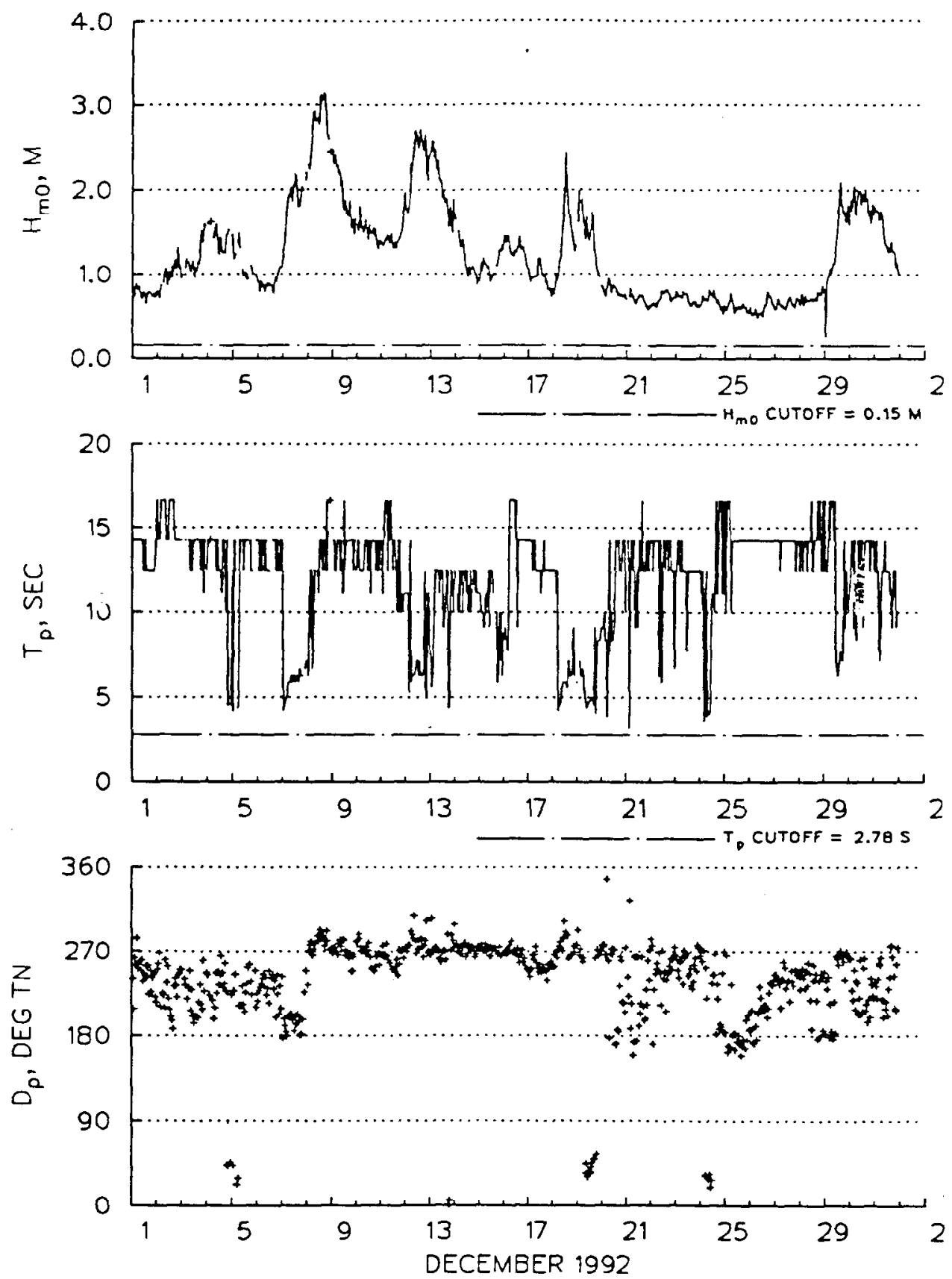

Figure G2. Time series plot for Catalina Ridge gage (46025), December 1992, first deployment 


\section{CATALINA RIDGE \\ NDBC 46025 \\ $33.75 \mathrm{~N}, 119.07 \mathrm{~W}$}
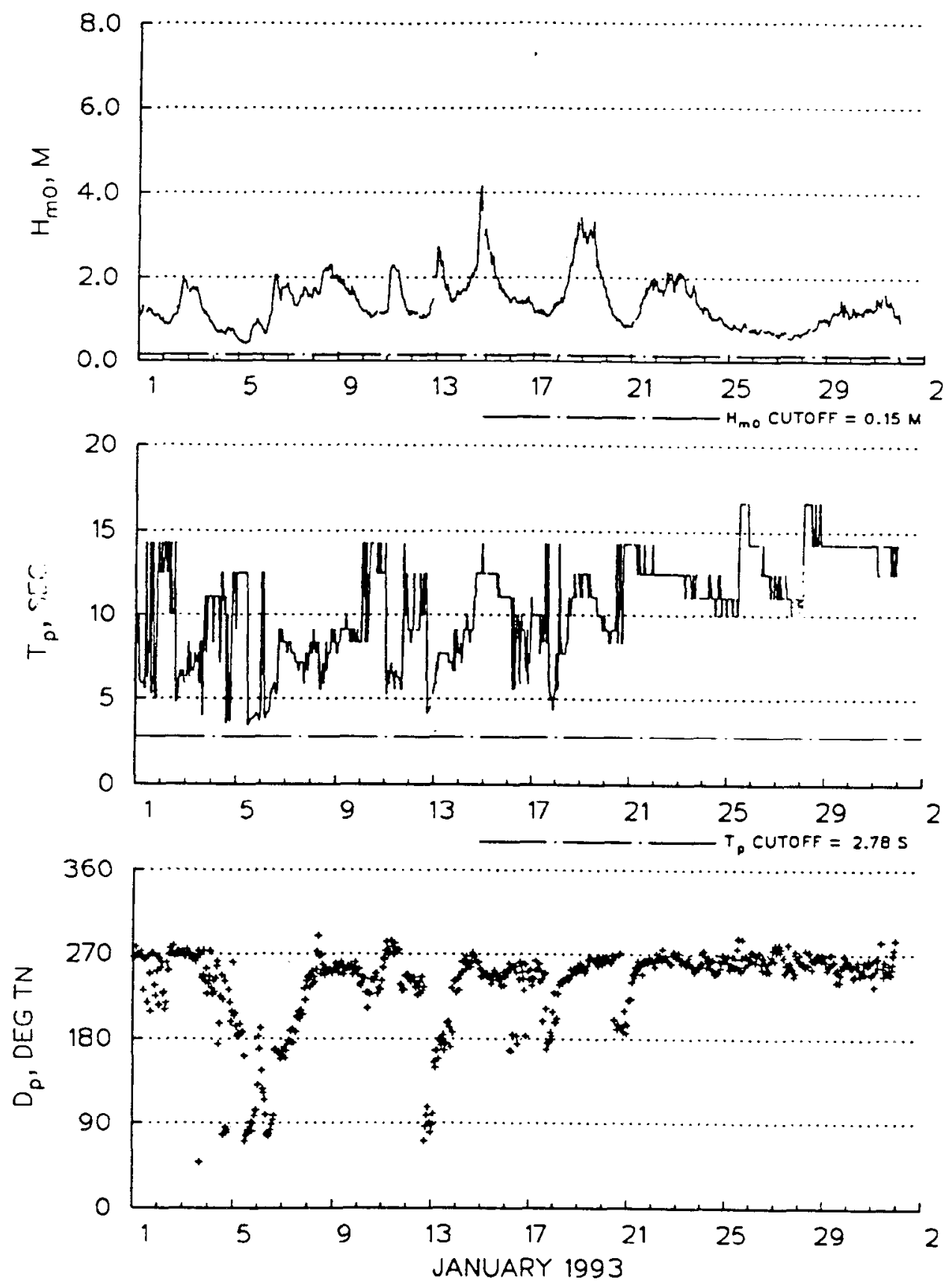

Figure G3. Time series plot for Catalina Ridge gage (46025), January 1993, first deplayment 


\section{CATALINA RIDGE}

NDBC 46025

$33.75 \mathrm{~N}, 119.07 \mathrm{~W}$
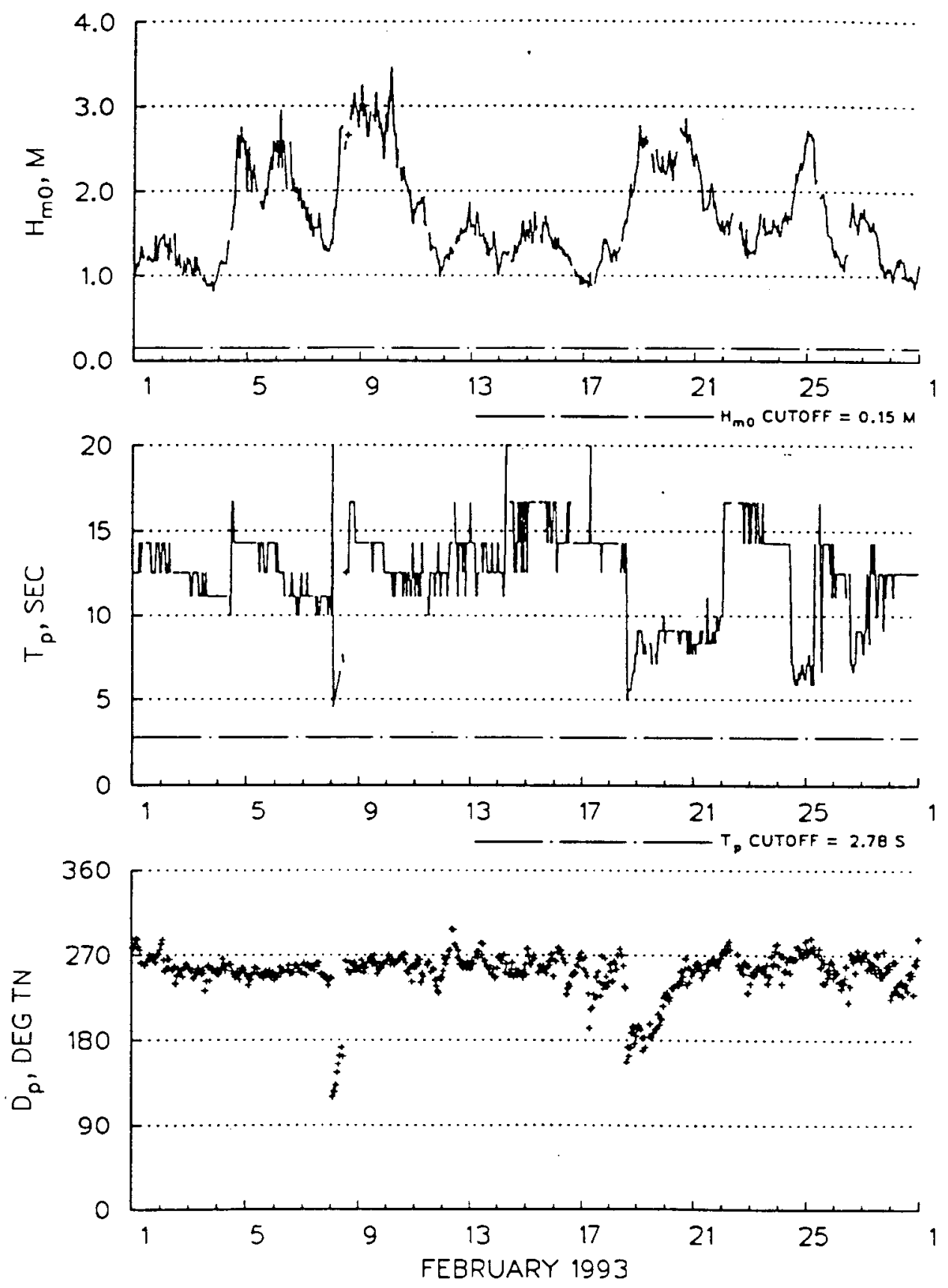

Figure G4. Time series plot for Catalina Ridge gage (46025), February 1993, first deployment 


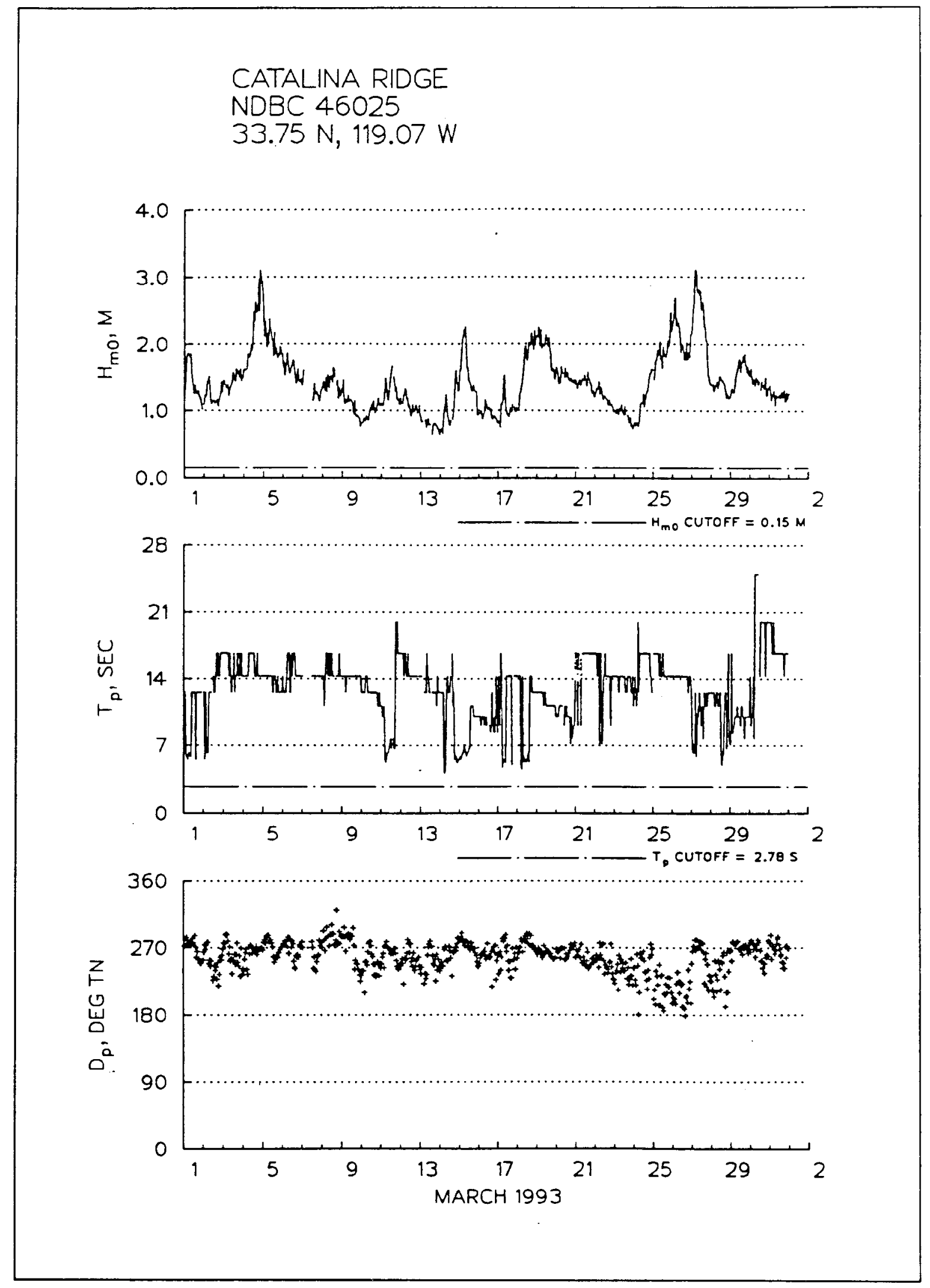

Figure G5. Time series plot for Catalina Ridge gage (46025), March 1993, first deployment G6 
CATALINA RIDGE

NDBC 46025

$33.75 \mathrm{~N}, 119.07 \mathrm{~W}$
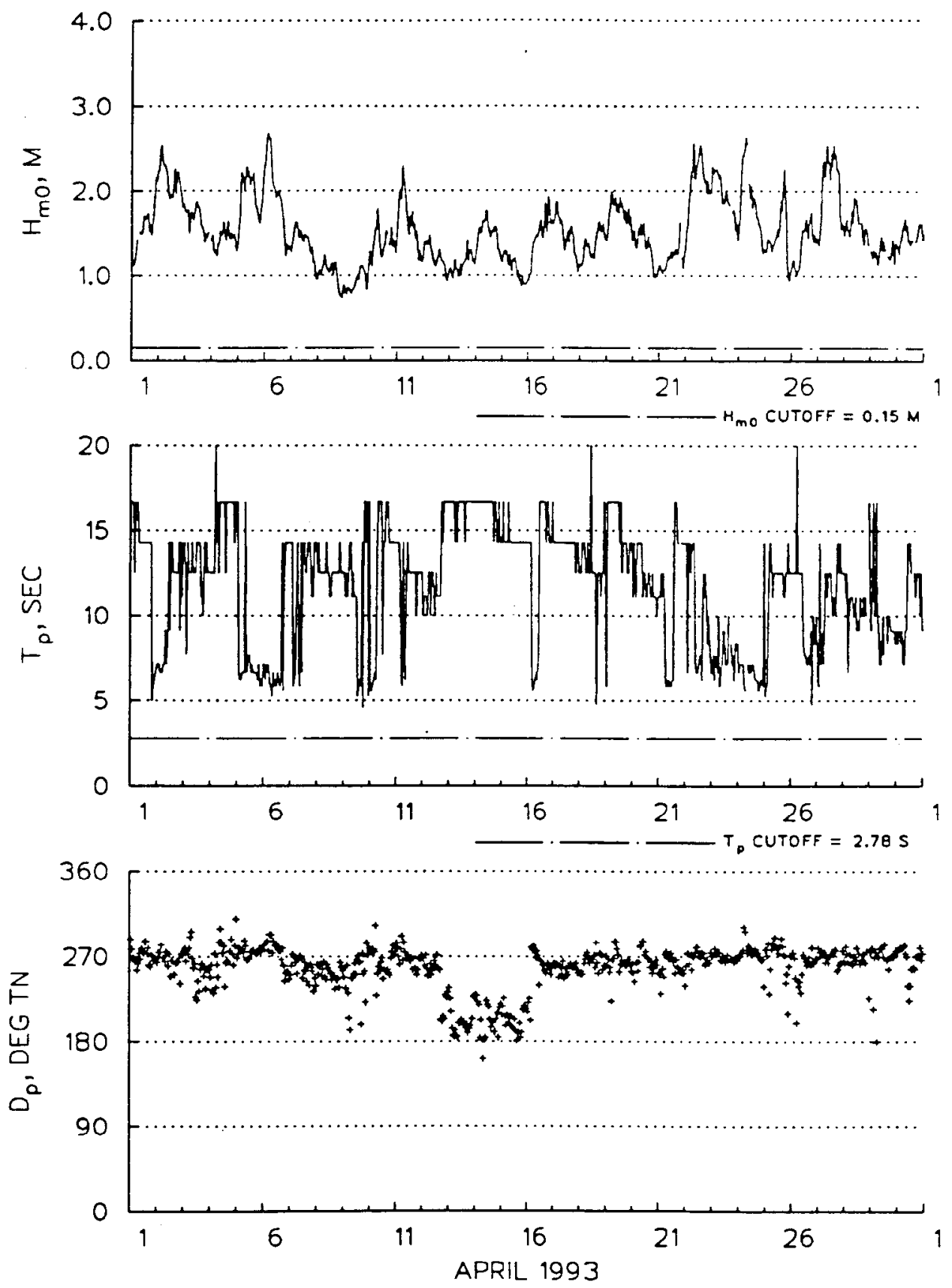

Figure G6. Time series plot for Redondo gage (46045), April 1993, first deployment 


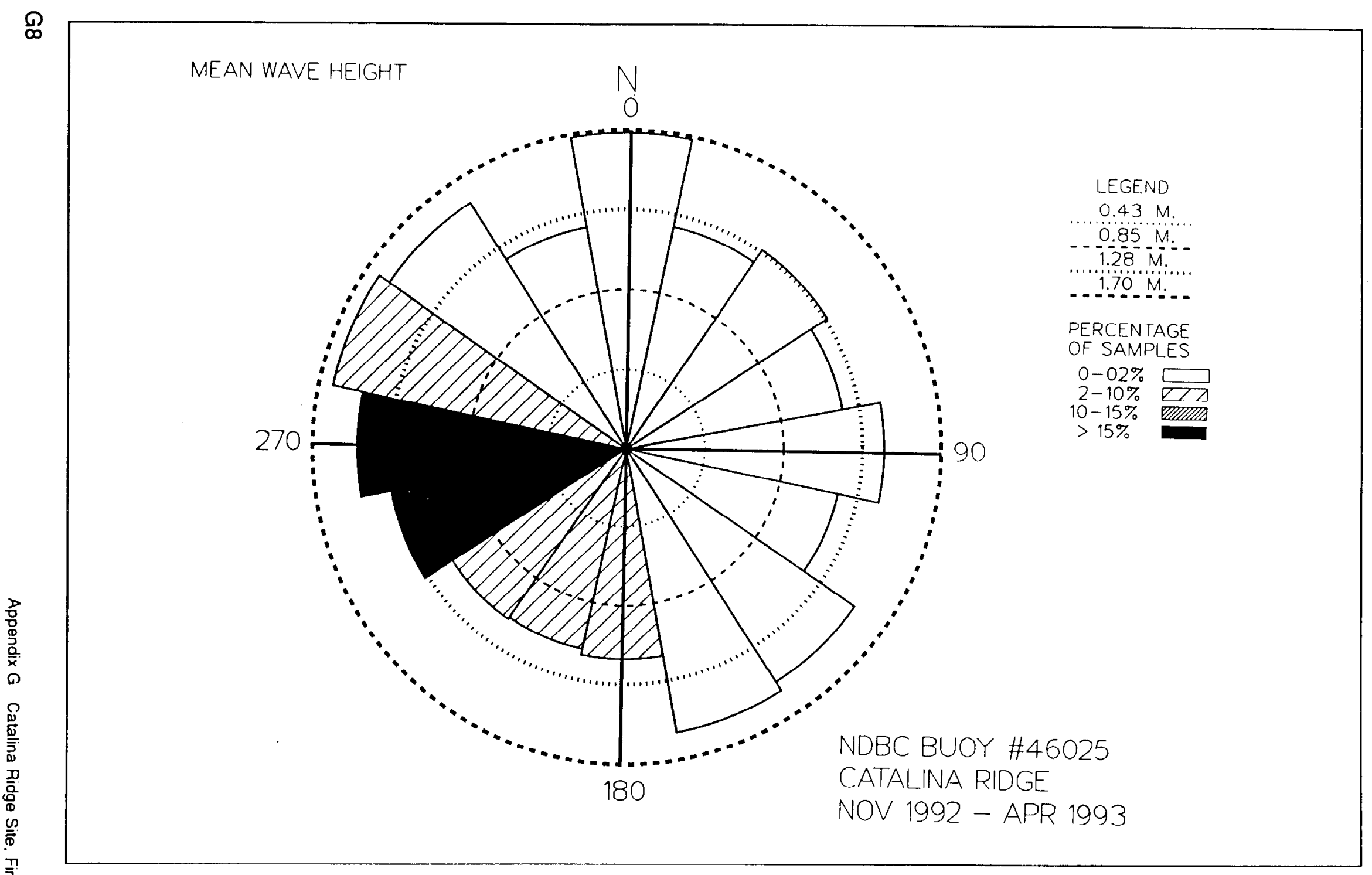

Figure G7. Wave rose plot for Catalina Ridge gage (NDBC 46025), first deployment 
Table G1

Mean/Max Values for Catalina Ridge (NDBC 46025)

First Deployment

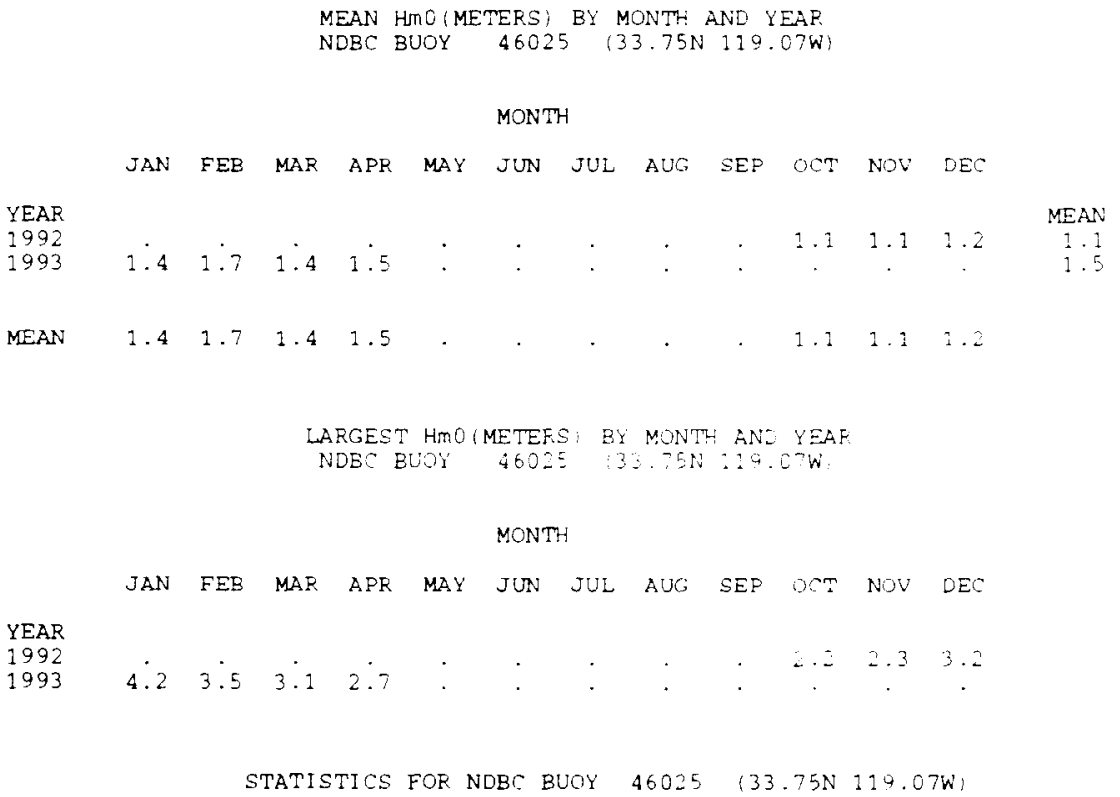




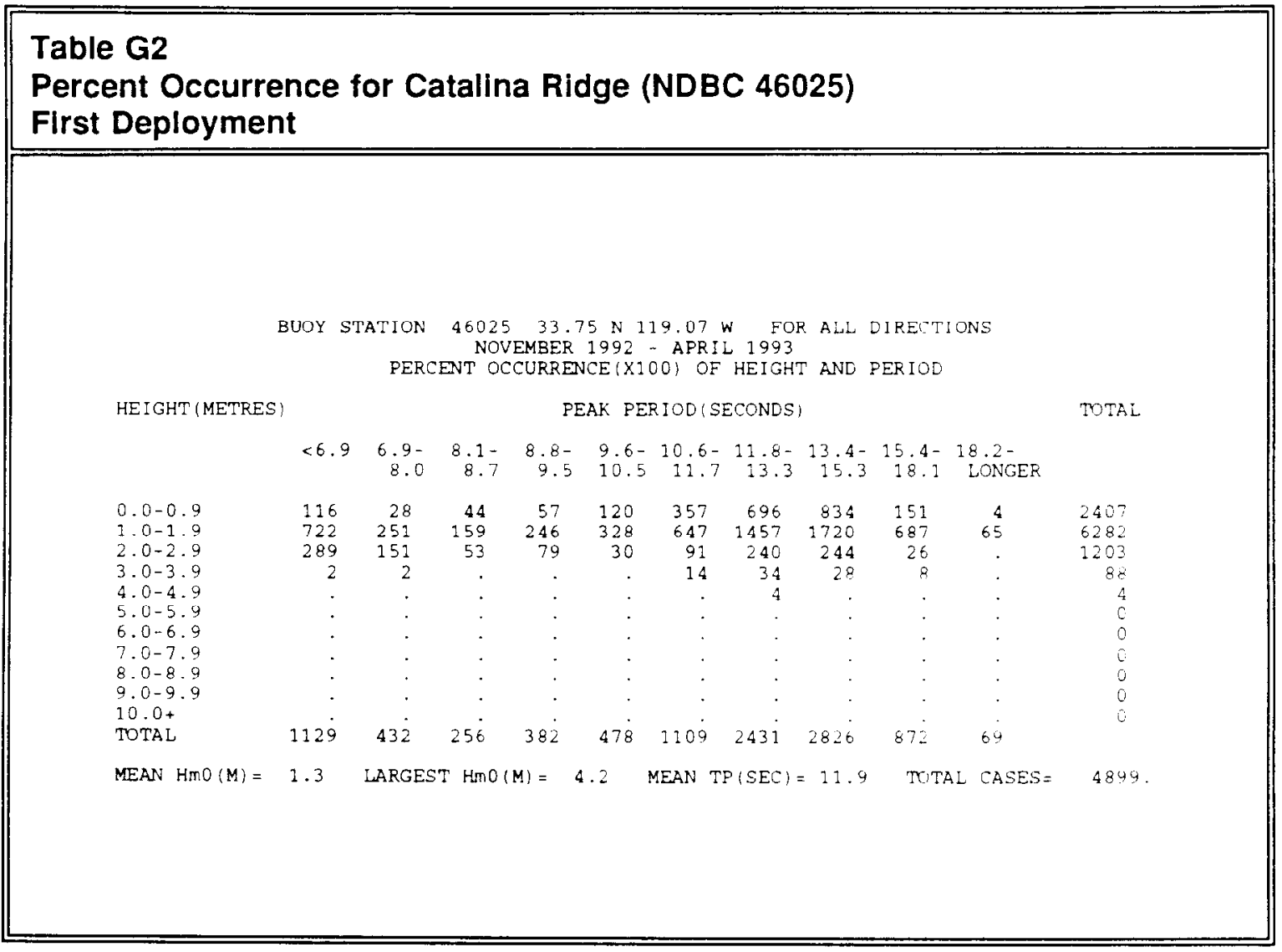




\section{Appendix $\mathrm{H}$ North Breakwater Site, Second Deployment}


NORTH BREAKWATER

GAGE \#020

$33.85 \mathrm{~N} 118.41 \mathrm{~W}$
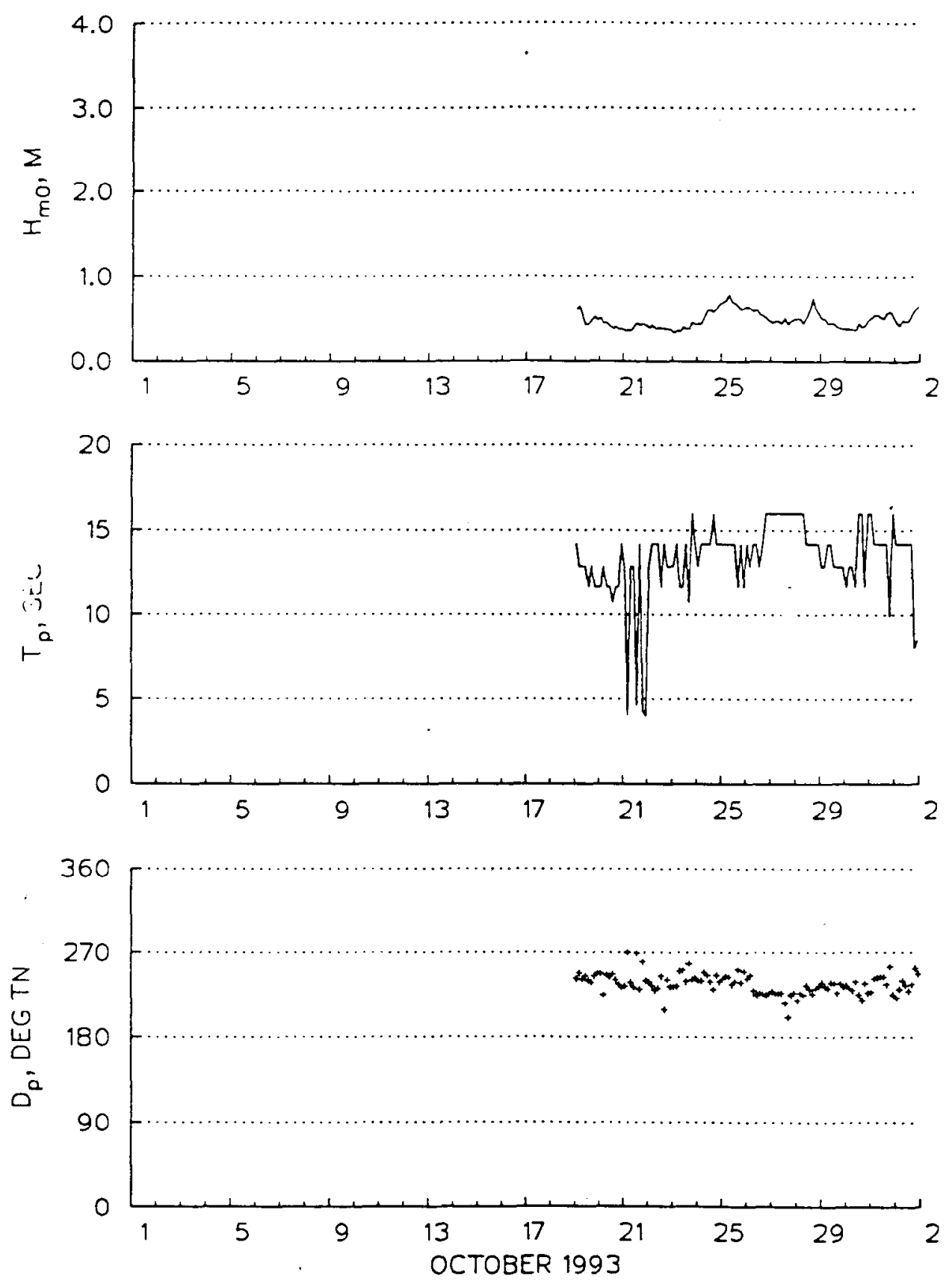

Figure H1. Time series plot for North Breakwater gage (020), October 1993, second deployment 
NORTH BREAKWATER

GAGE \#020

$33.85 N 118.41 \mathrm{~W}$
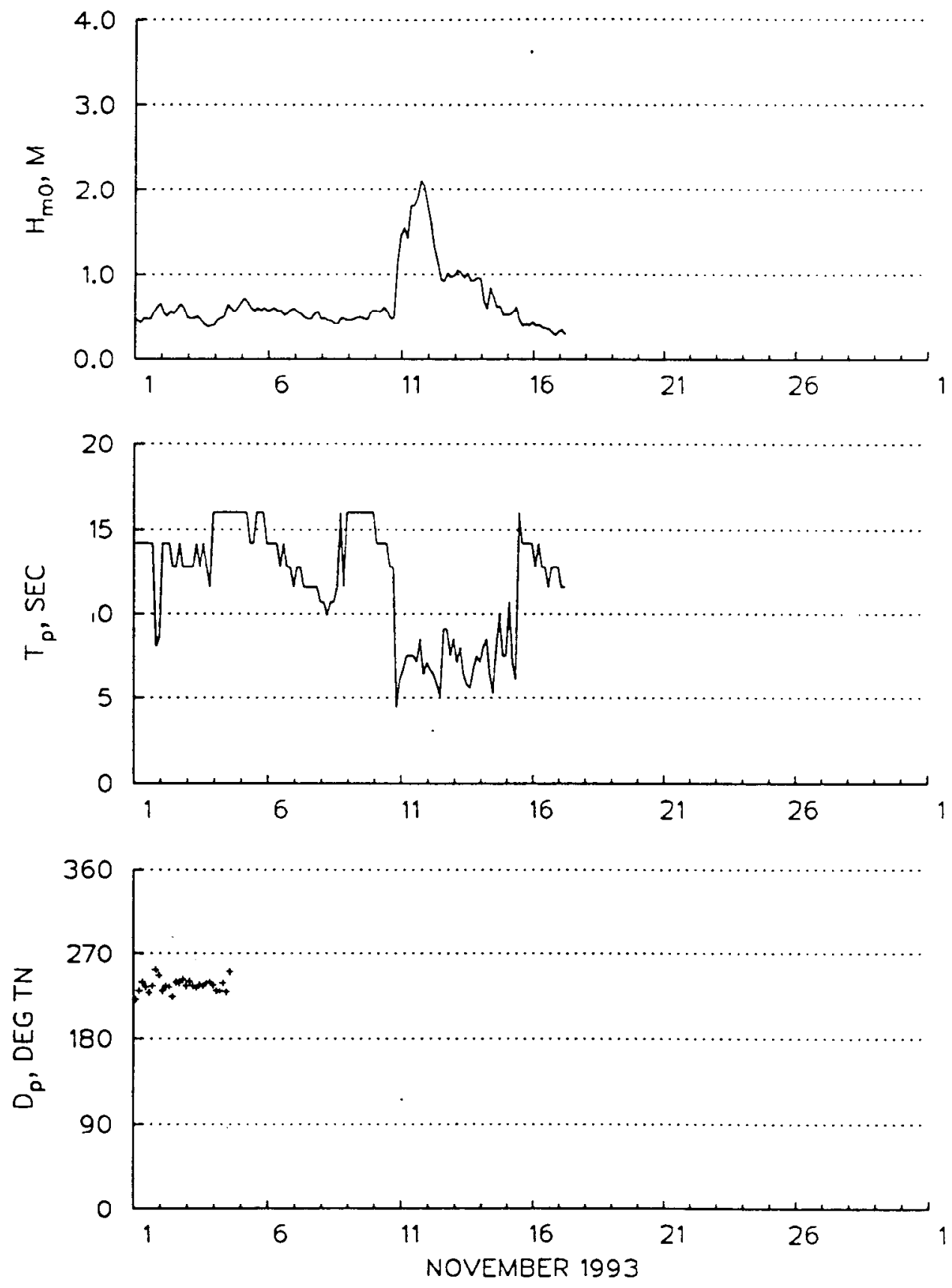

Figure H2. Time series plot for North Breakwater gage (020), November 1993, second deployment 


\section{Table H1 \\ Mean/Max Values for North Breakwater (020) \\ Second Deployment}

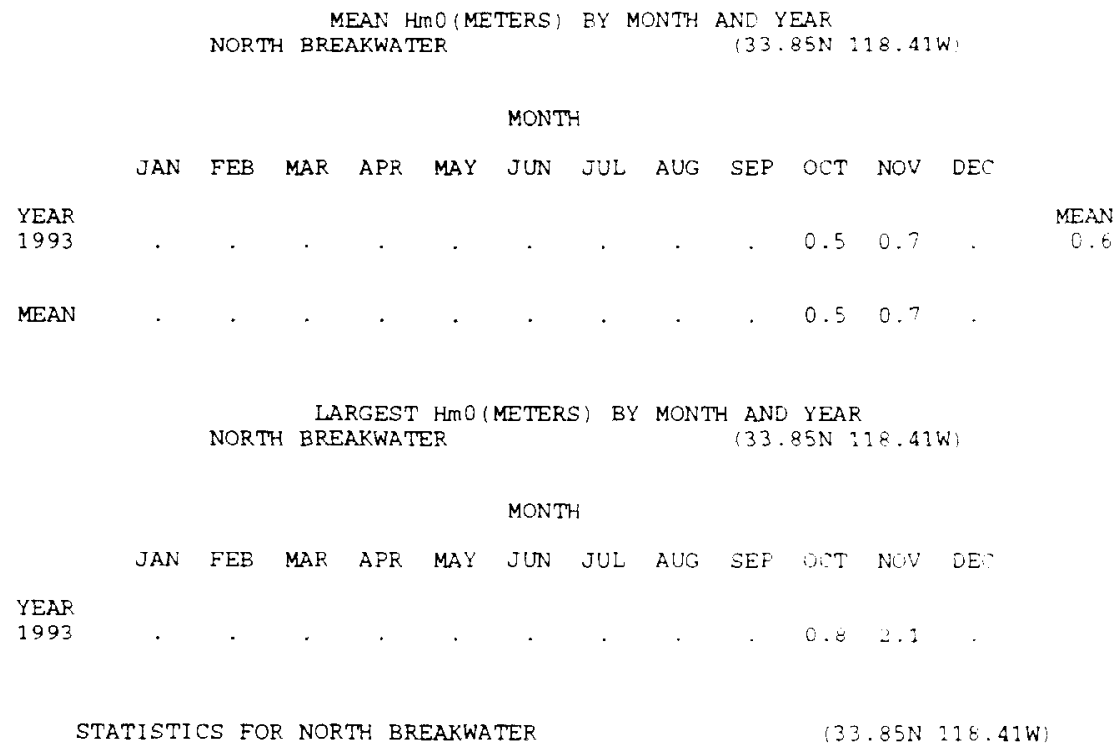




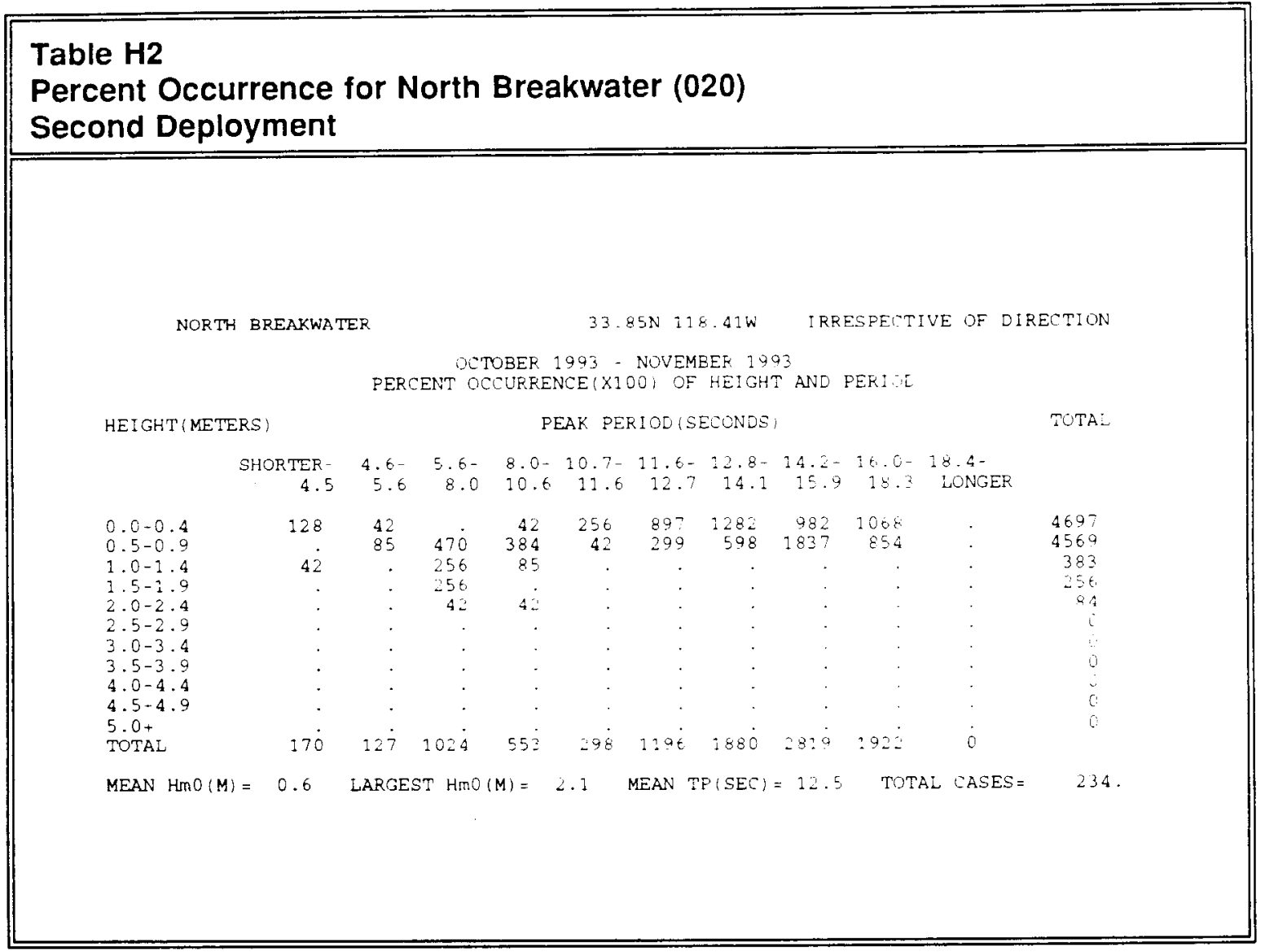




\section{Appendix I South Breakwater Site, Second Deployment}




\section{SOUTH BREAKWATER \\ GAGE \# RB4A \\ $33.84 \mathrm{~N} \mathrm{118.40} \mathrm{W}$}
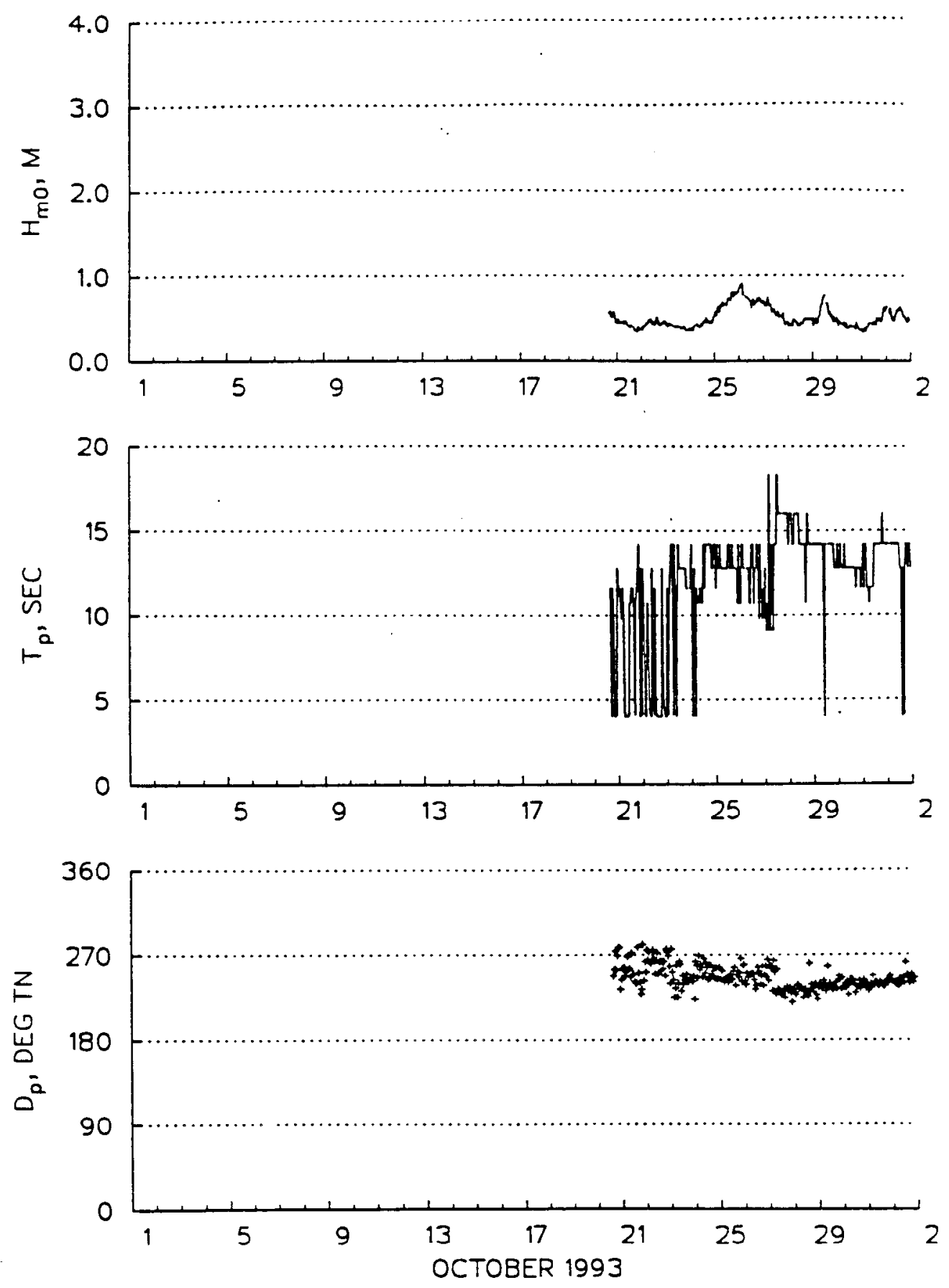

Figure 11. Time series plot for South Breakwater gage (RB4A), October 1993, second deployment 


\section{SOUTH BREAKWATER}

GAGE \# RB4A

$33.84 \mathrm{~N} 118.40 \mathrm{~W}$
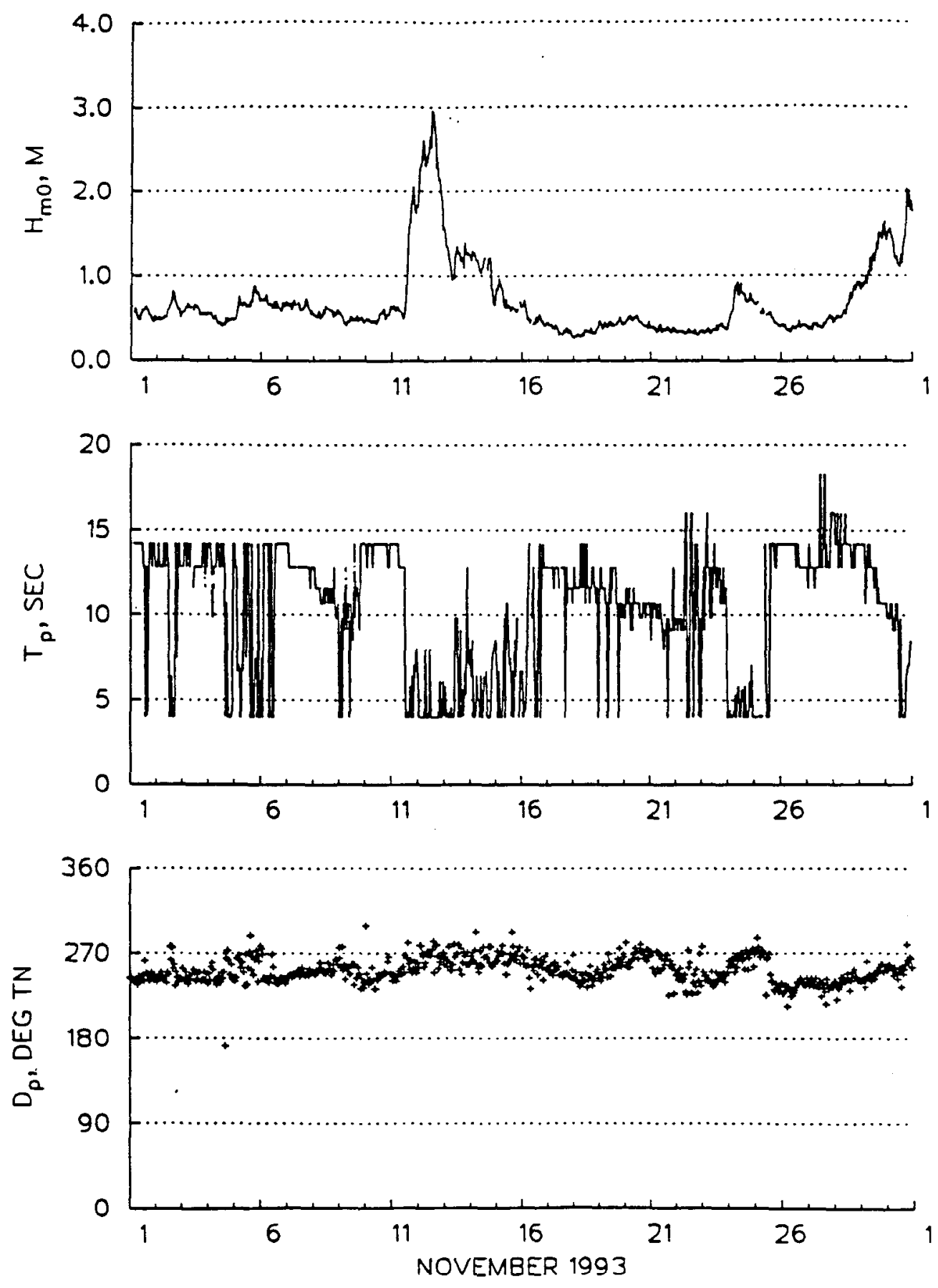

Figure 12. Time series plot for South Breakwater gage (RB4A), November 1993, second deployment 


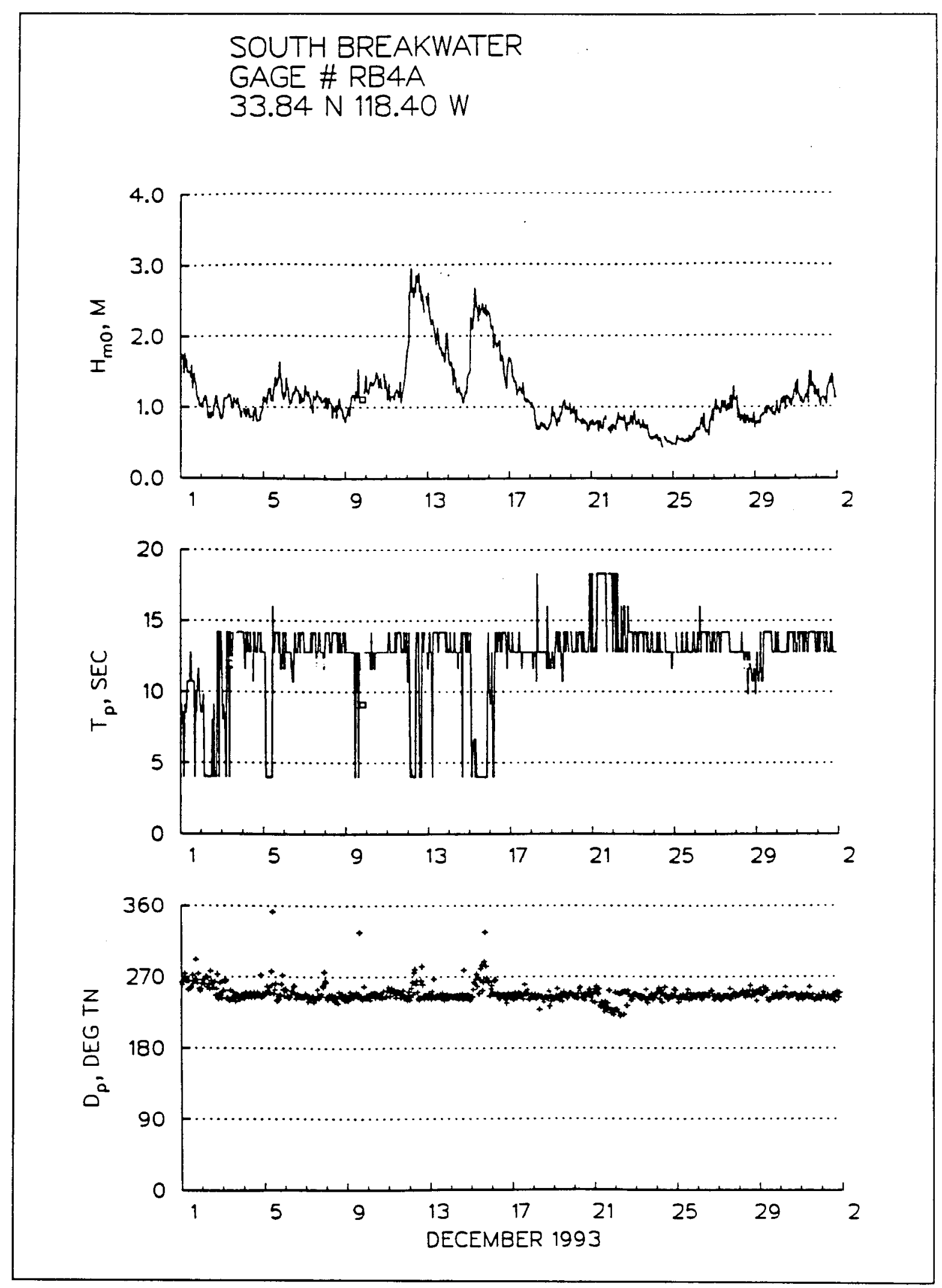

Figure 13. Time series plot for South Breakwater gage (RB4A), December 1993, second deployment 
SOUTH BREAKWATER

GAGE \# RB4A

$33.84 \mathrm{~N} 118.40 \mathrm{~W}$
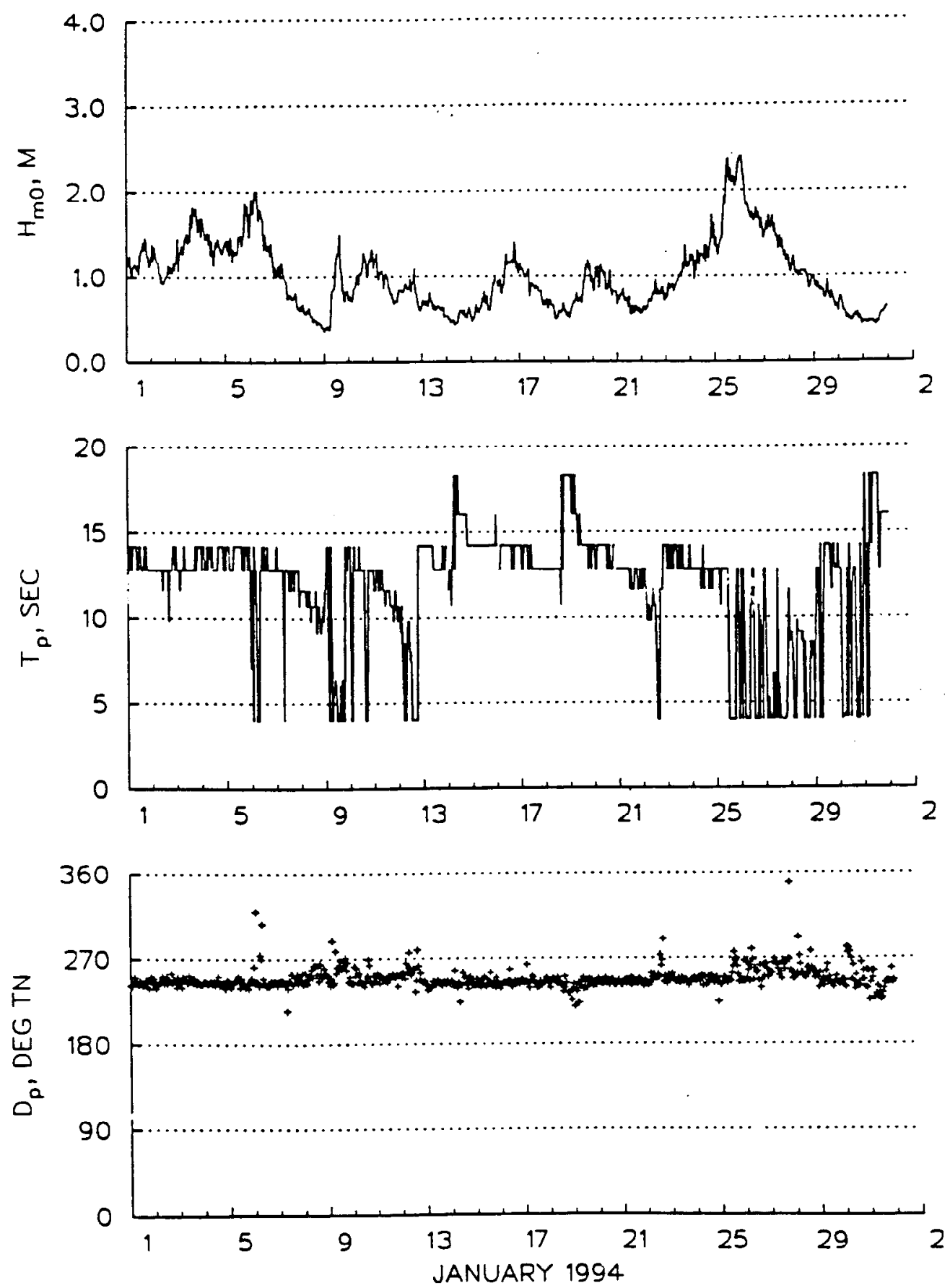

Figure 14. Time series plot for South Breakwater gage (RB4A), January 1994, second deployment 


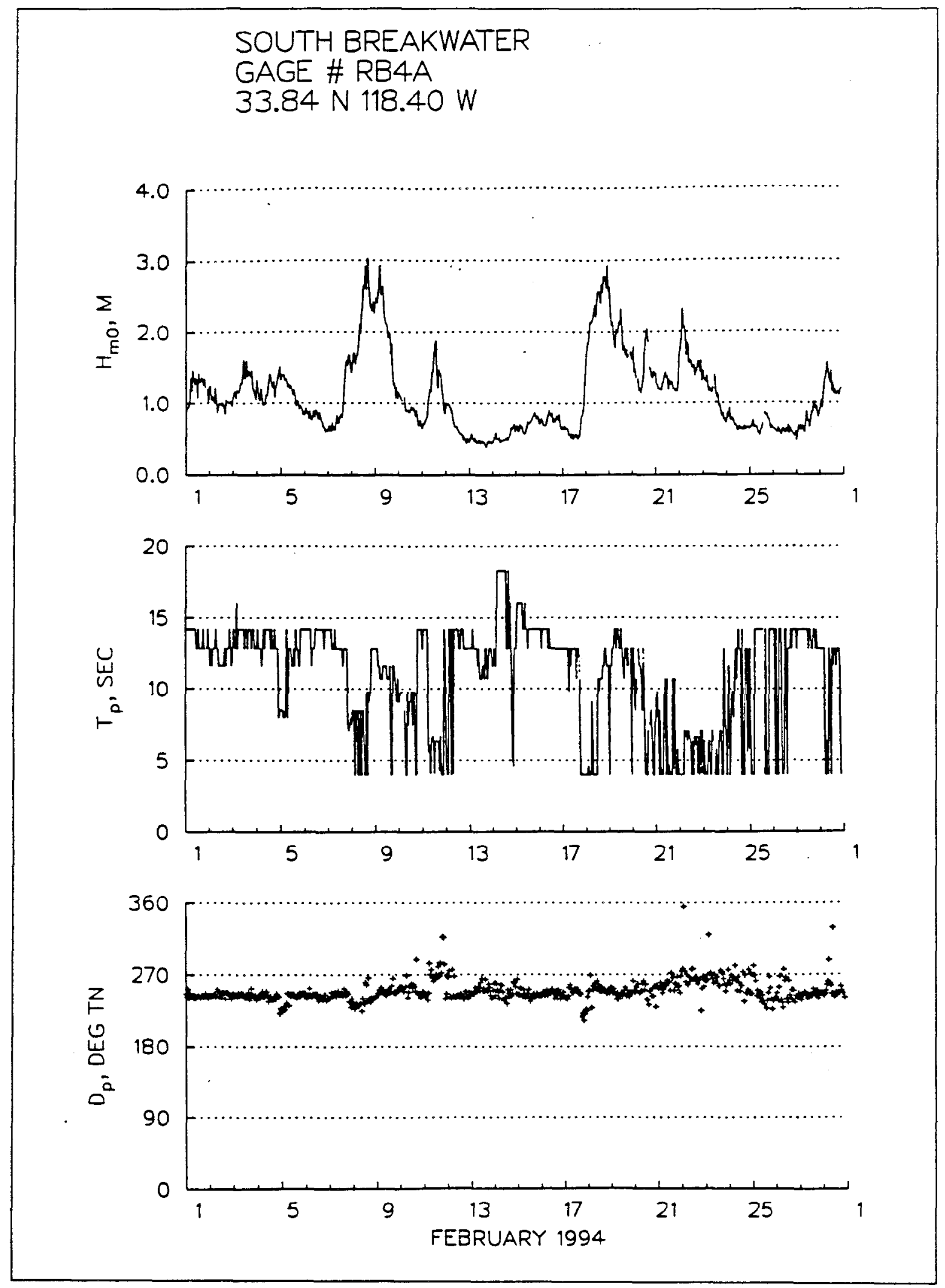

Figure 15. Time series plot for South Breakwater gage (RB4A), February 1994, second deployment 
SOUTH BREAKWATER

GAGE \# RB4A

33.84 N $118.40 \mathrm{~W}$
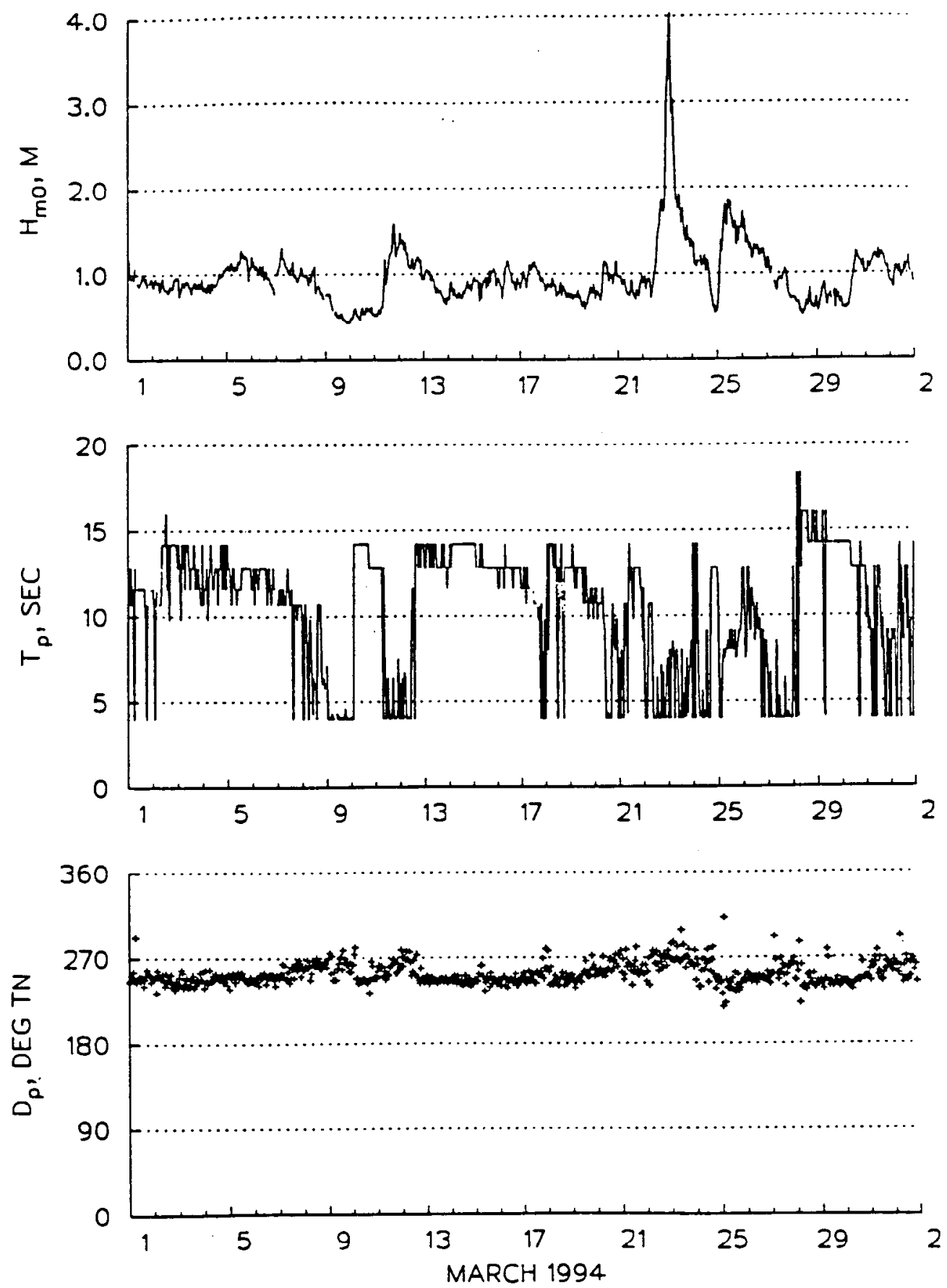

Figure 16. Time series plot for South Breakwater gage (RB4A), March 1994, second deployment 


\section{SOUTH BREAKWATER GAGE \# RB4A \\ $33.84 \mathrm{~N} 118.40 \mathrm{~W}$}
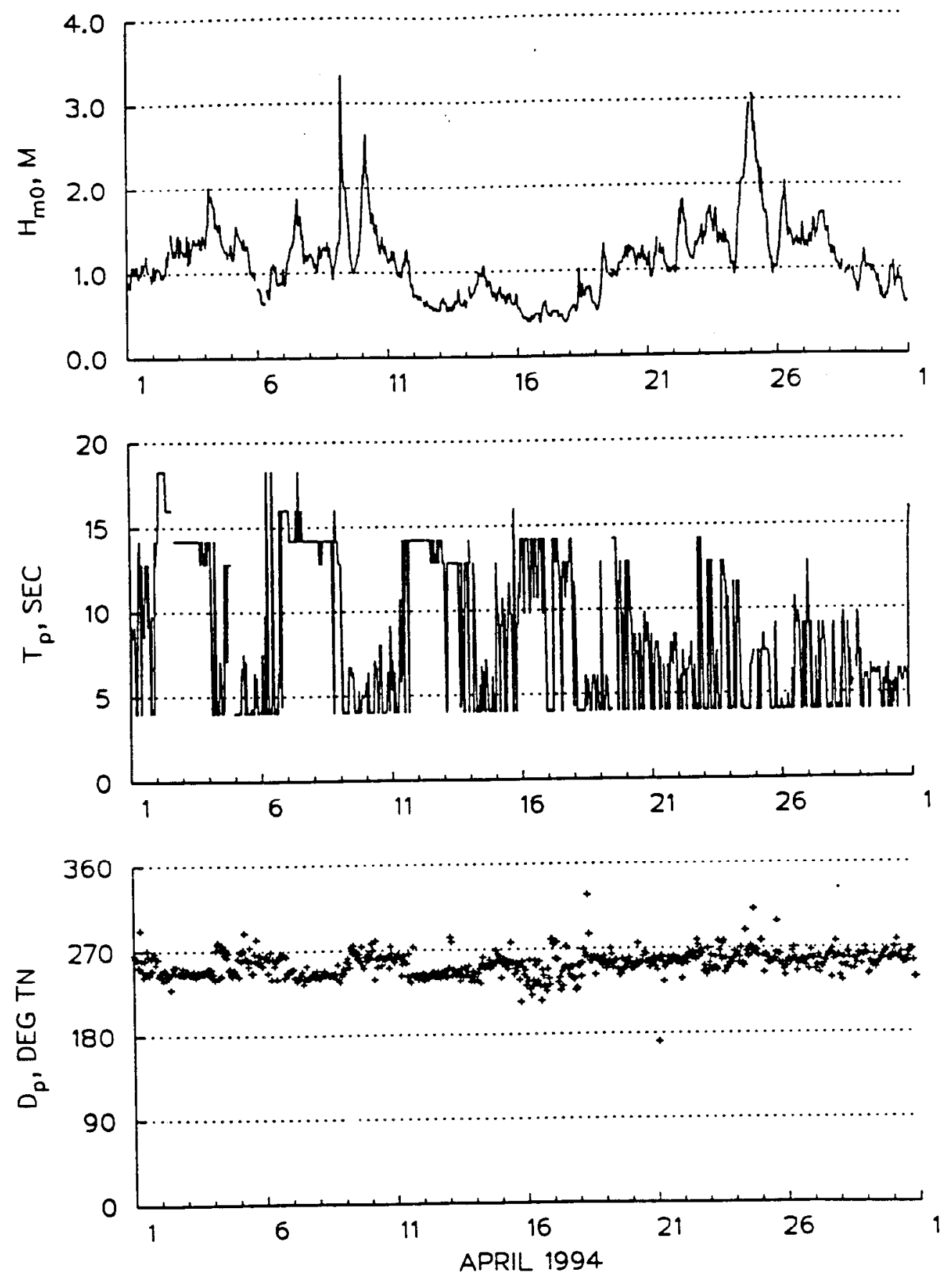

Figure 17. Time series plot for South Breakwater gage (RB4A), April 1994, second deployment 


\section{SOUTH BREAKWATER}

GAGE \# RB4A

$33.84 \mathrm{~N} 118.40 \mathrm{~W}$
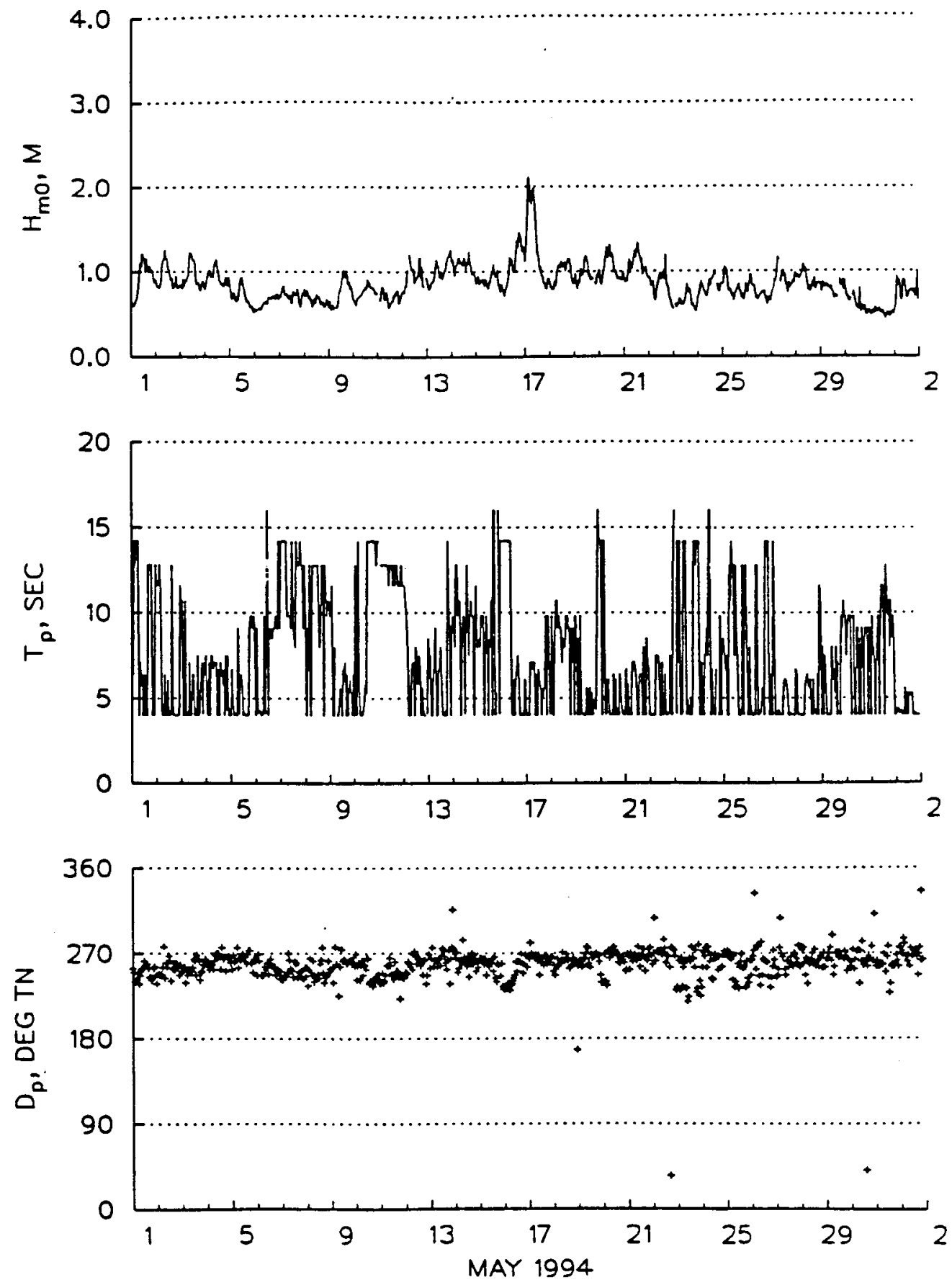

Figure 18. Time series plot for South Breakwater gage (RB4A), May 1994, second deployment 
SOUTH BREAKWATER

GAGE \# RB4A

$33.84 \mathrm{~N} 118.40 \mathrm{~W}$
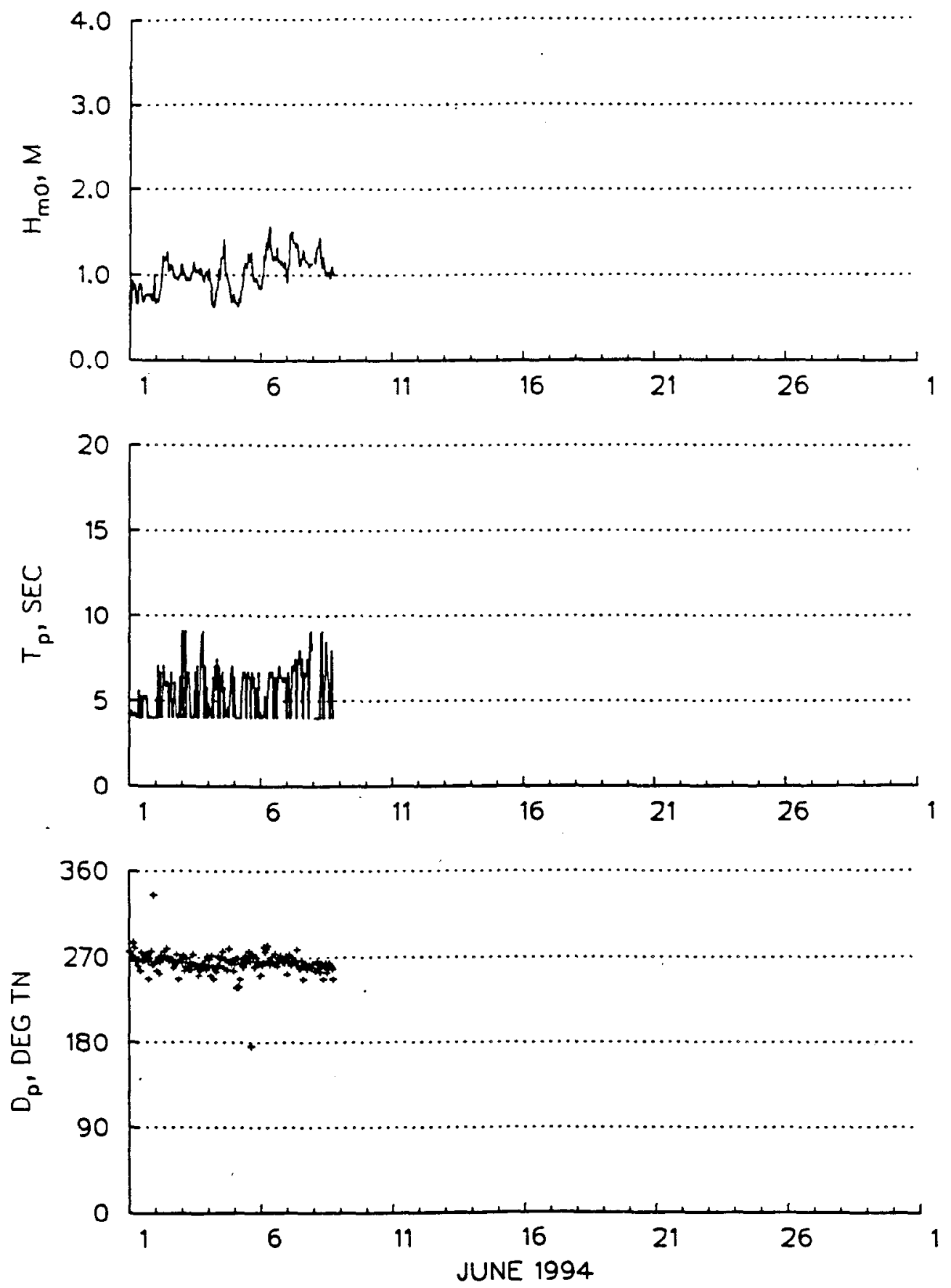

Figure 19. Time series plot for South Breakwater gage (RB4A), June 1994, second deployment 


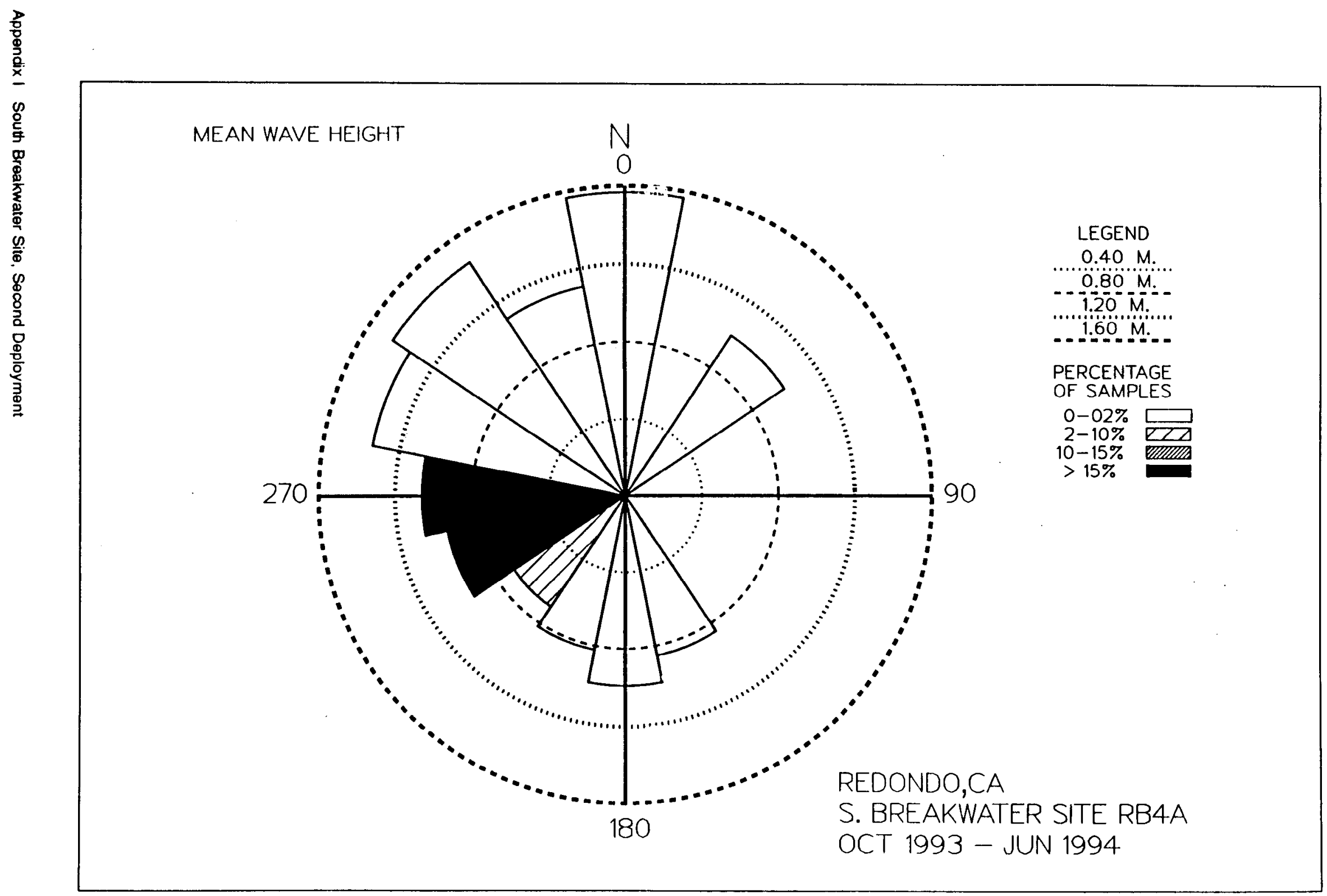

झ $\quad$ Figure 110. Wave rose for South Breakwater gage (RB4A), second deployment 


\section{Table 11}

Mean/Max Values for South Breakwater (RB4A)

Second Deployment

MEAN HMO (METERS) BY MONTH AND YEAR

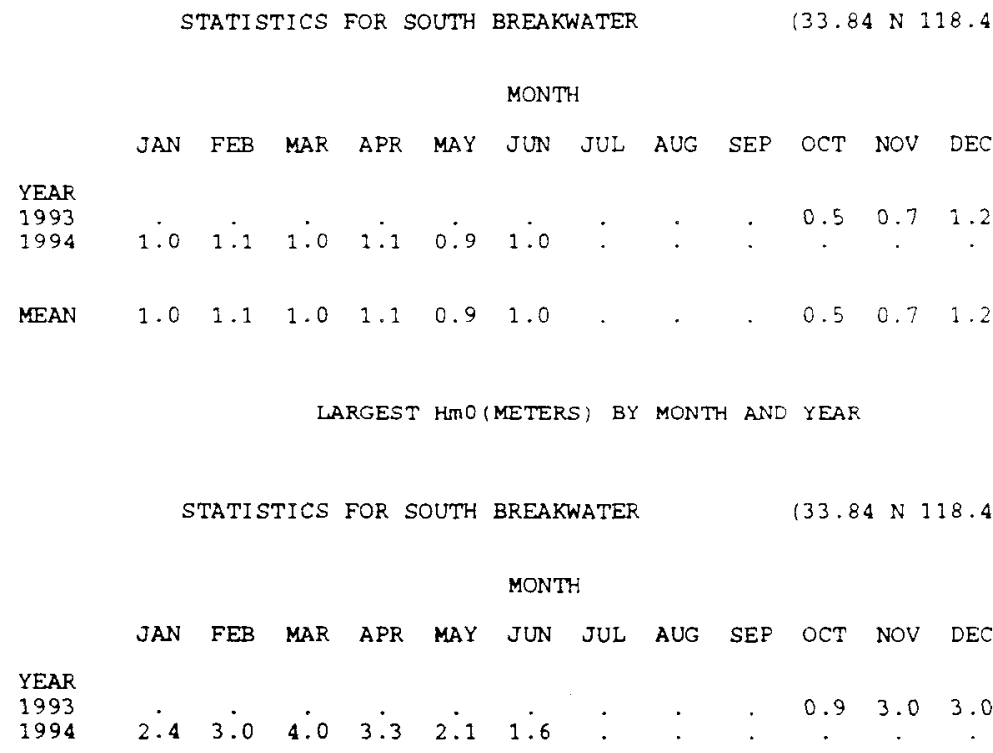

STATISTICS FOR SOUTH BREAKWATER

$(33.84 \mathrm{~N} 118.40 \mathrm{~W})$

THE MEAN SIGNIFICANT WAVE HEIGHT (METERS) =

THE MEAN PEAK WAVE PERIOD (SECONDS) =

THE MOST FREQUENT 22.5 (CENTER) DIRECTION BAND (DEGREES) =

247.5

THE STANDARD DEVIATION OF HMO (METERS) =

THE STANDARD DEVIATION OF TP (SECONDS) =

THE LARGEST HMO (METERS) =

THE TP(SECONDS)ASSOC. WITH THE LARGEST HMO=

THE PEAK DIRECTION (DEGREES) ASSOC. WITH THE LARGEST HMO= 
Table 12

Percent Occurrence for South Breakwater (RB4A)

Second Deployment

SOITH BRFAKWATER $\quad 33.84 \mathrm{~N} 118.40 \mathrm{~W}$ FOR AII DIRFCTIONS

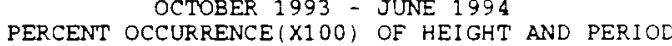

HEI GHT ( METERS)

PEAK PERIOD (SECONDS)

WOIAL

SHORTER- 4.6- 5.6- 8.0- $10.7-11.6-12.8-14.2-16.0-18.4-$

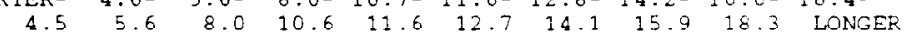

$0.0-0$.

$0.5-0.9$

$1.0-1.4$

$1.5-1.9$

$2.0-2.4$

$2 \cdot 5-2.9$

$3.5-3.9$

$4.0-4.4$

4. $5-4.9$

$5.0+$

TOTAL

$1170 . \quad 36 \quad 36$

$\begin{array}{lllll}1133 & 1261 & 1225 & 2798 & 232\end{array}$

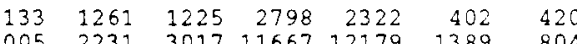

$\begin{array}{rrrrrrrrrr}9253 & 841 & 4005 & 4005 & 2231 & 3017 & 11667 & 12179 & 1389 & 80 \\ 7187 & 274 & 3712 & 3035 & 987 & 1499 & 7809 & 5230 & 201 & 91\end{array}$

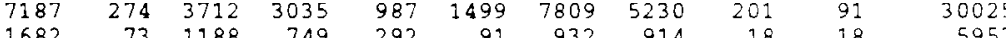

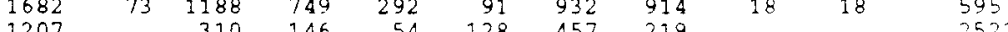

$\begin{array}{lllllllll}1207 & 0 & 310 & 146 & 54 & 128 & 457 & 219 & .\end{array}$

420

․ 36

$1 \dot{8}$

$21028^{\circ} 1242^{\circ} 9378^{\circ}$

9232

$4934^{\circ}$

$610623772 \quad 20937$

2010

1333

$\operatorname{MEAN} \operatorname{HMO}(M)=1.0 \quad$ LARGEST HMO $(M)=4.0 \quad \operatorname{MEAN} \operatorname{TP}(S E C)=10.2$ TOTAL CASES $=5468$. 


\section{Appendix J \\ Redondo Site, Second Deployment}




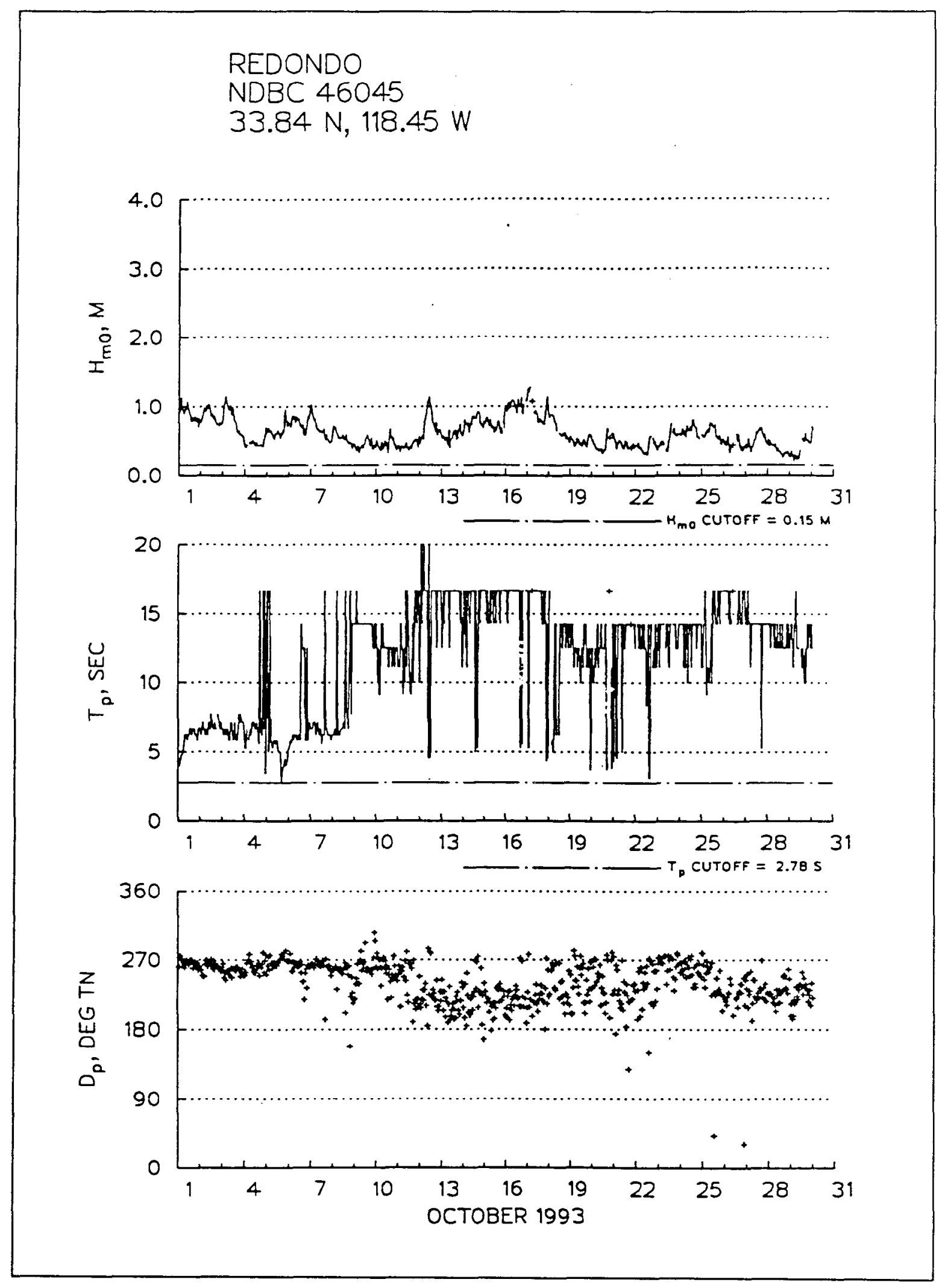

Figure J1. Time series plot for Redondo gage (NDBC 46045), October 1993, second deployment 


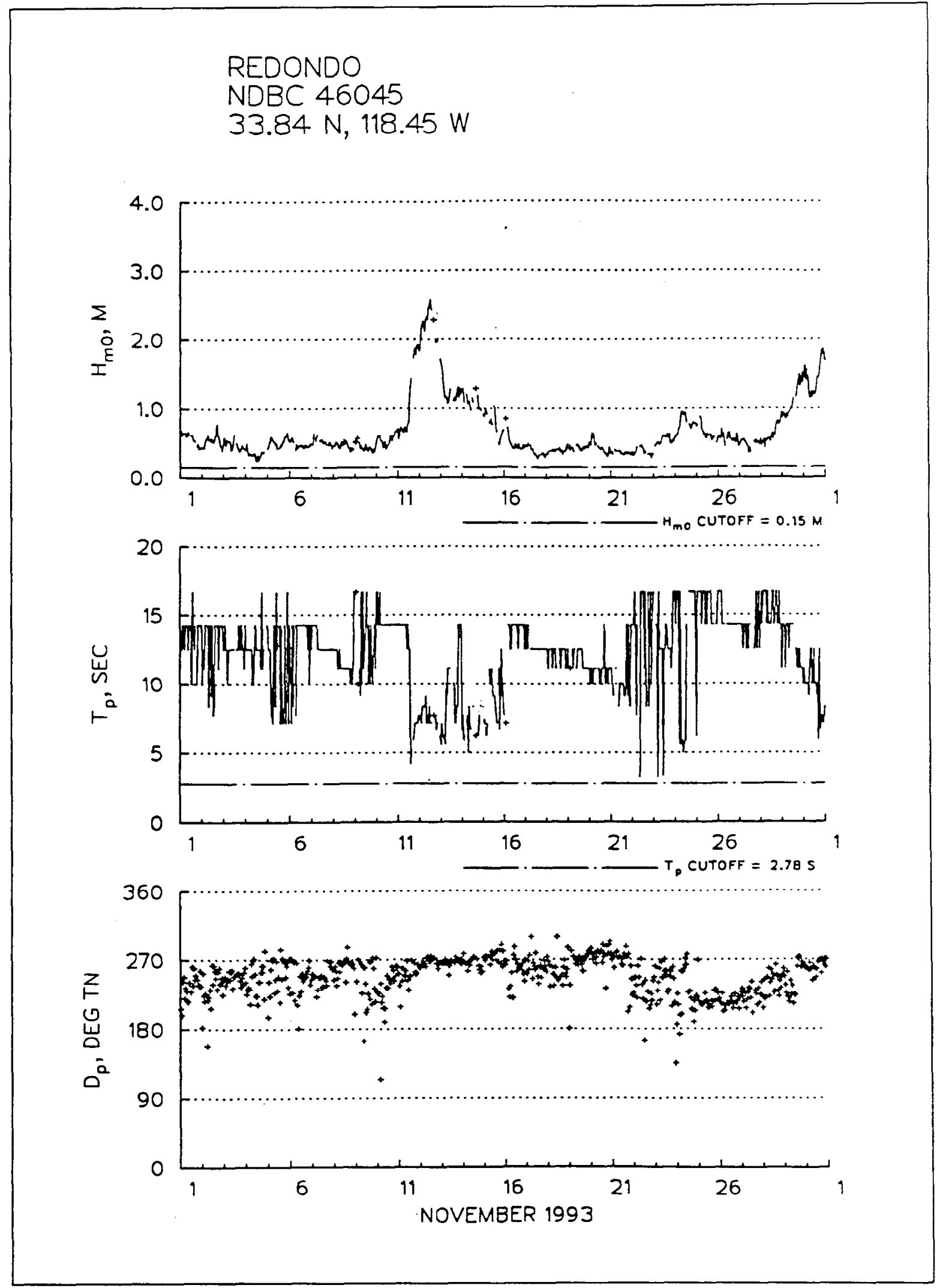

Figure J2. Time series plot for Redondo gage (NDBC 46045), November 1993, second deployment 
REDONDO

NDBC 46045

$33.84 \mathrm{~N}, 118.45 \mathrm{~W}$
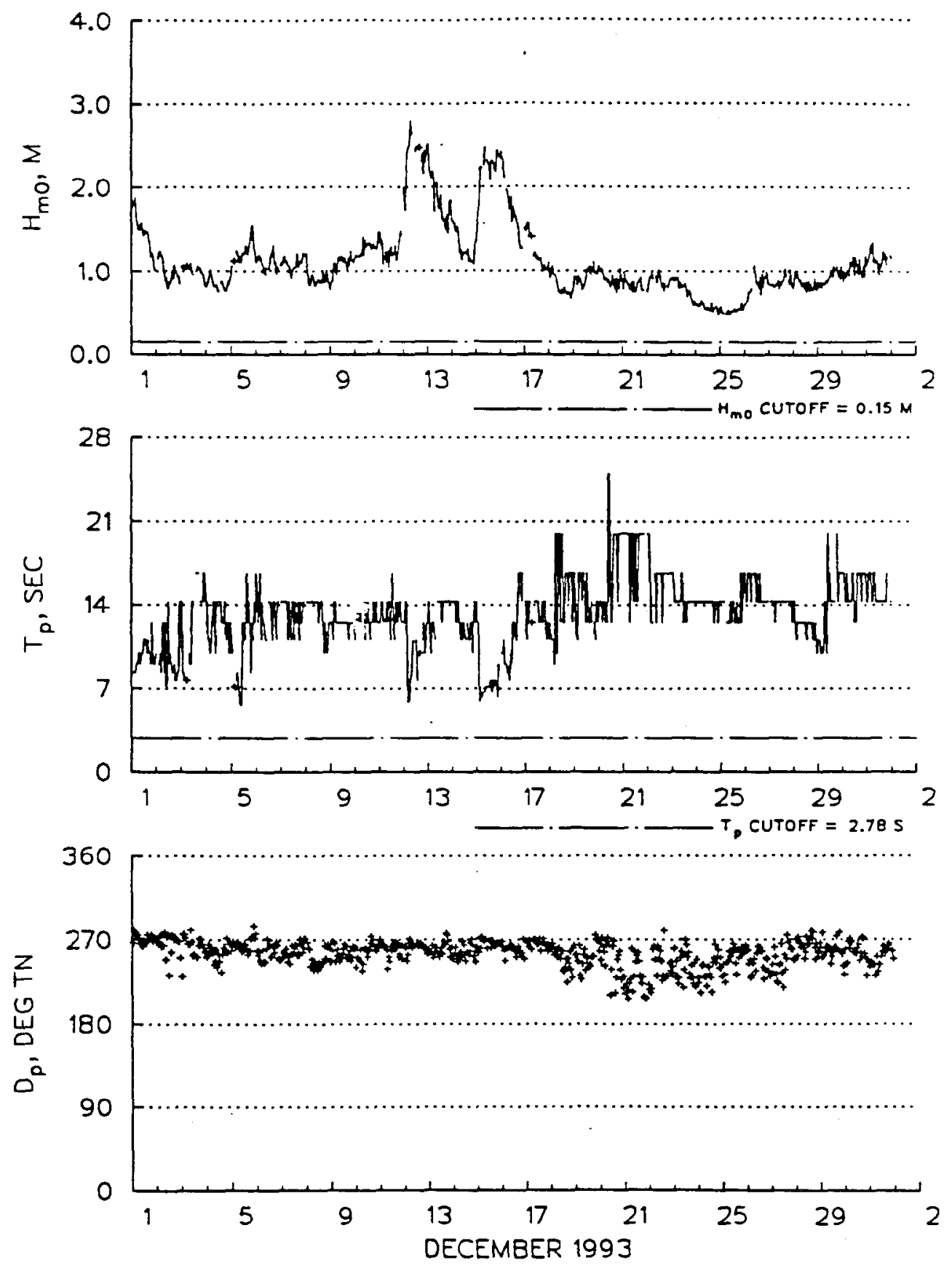

Figure J3. Time series plot for Redondo gage (NDBC 46045), December 1993, second deployment 


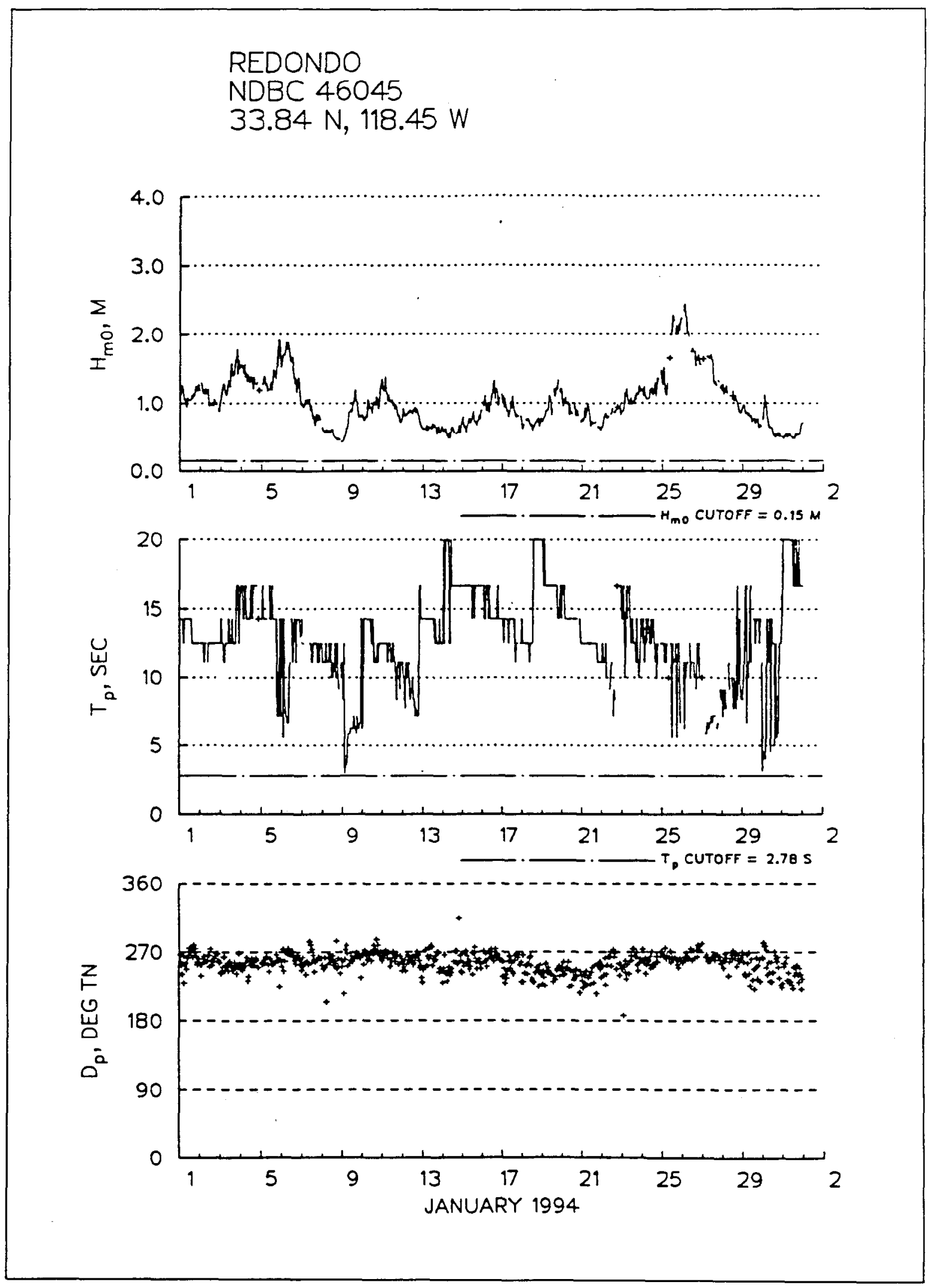

Figure J4. Time series plot for Redondo gage (NDBC 46045), January 1994, second deployment 
REDONDO

NDBC 46045

$33.84 \mathrm{~N}, 118.45 \mathrm{~W}$
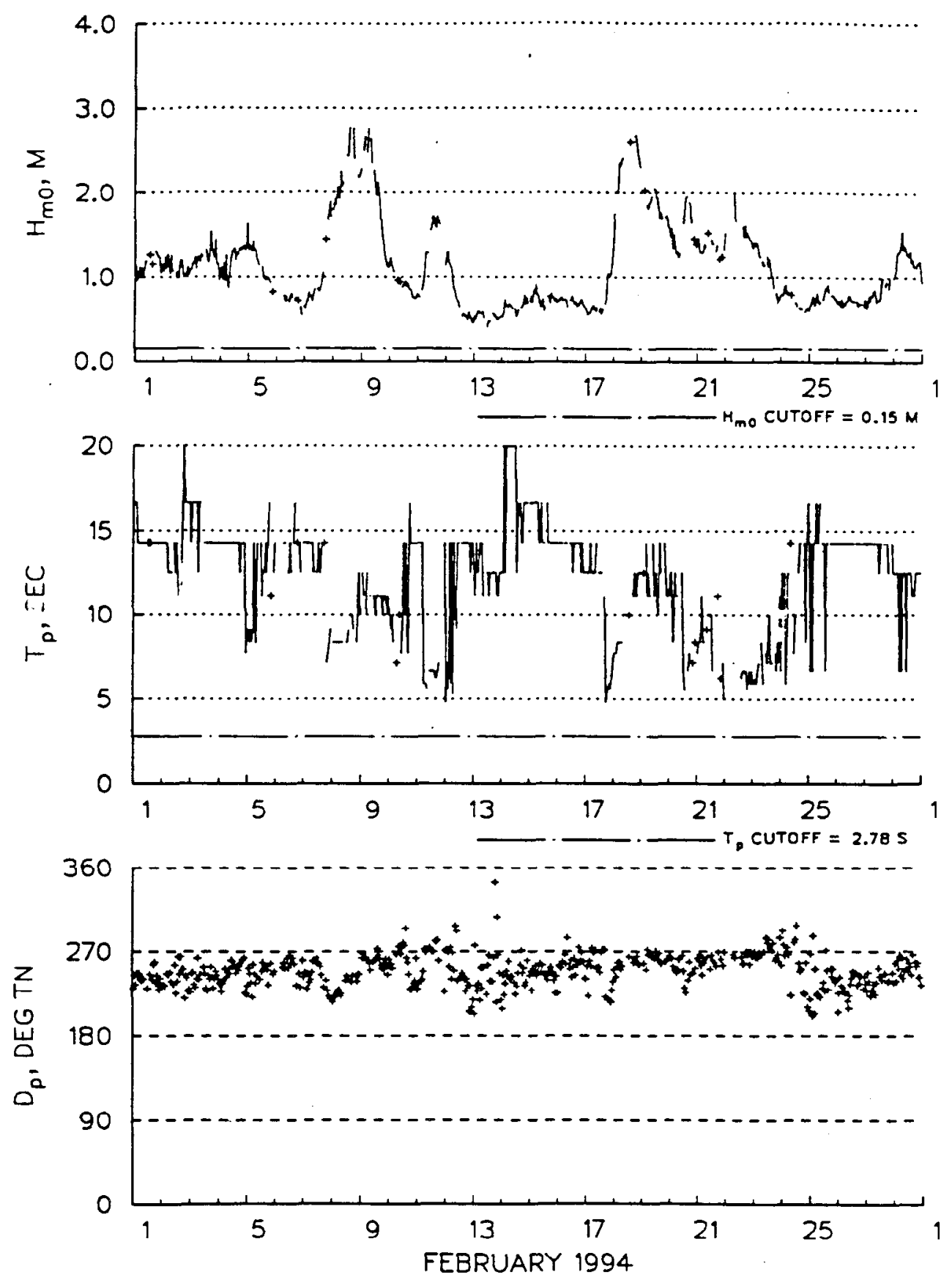

Figure J5. Time series plot for Redondo gage (NDBC 46045), February 1994, second deployment 


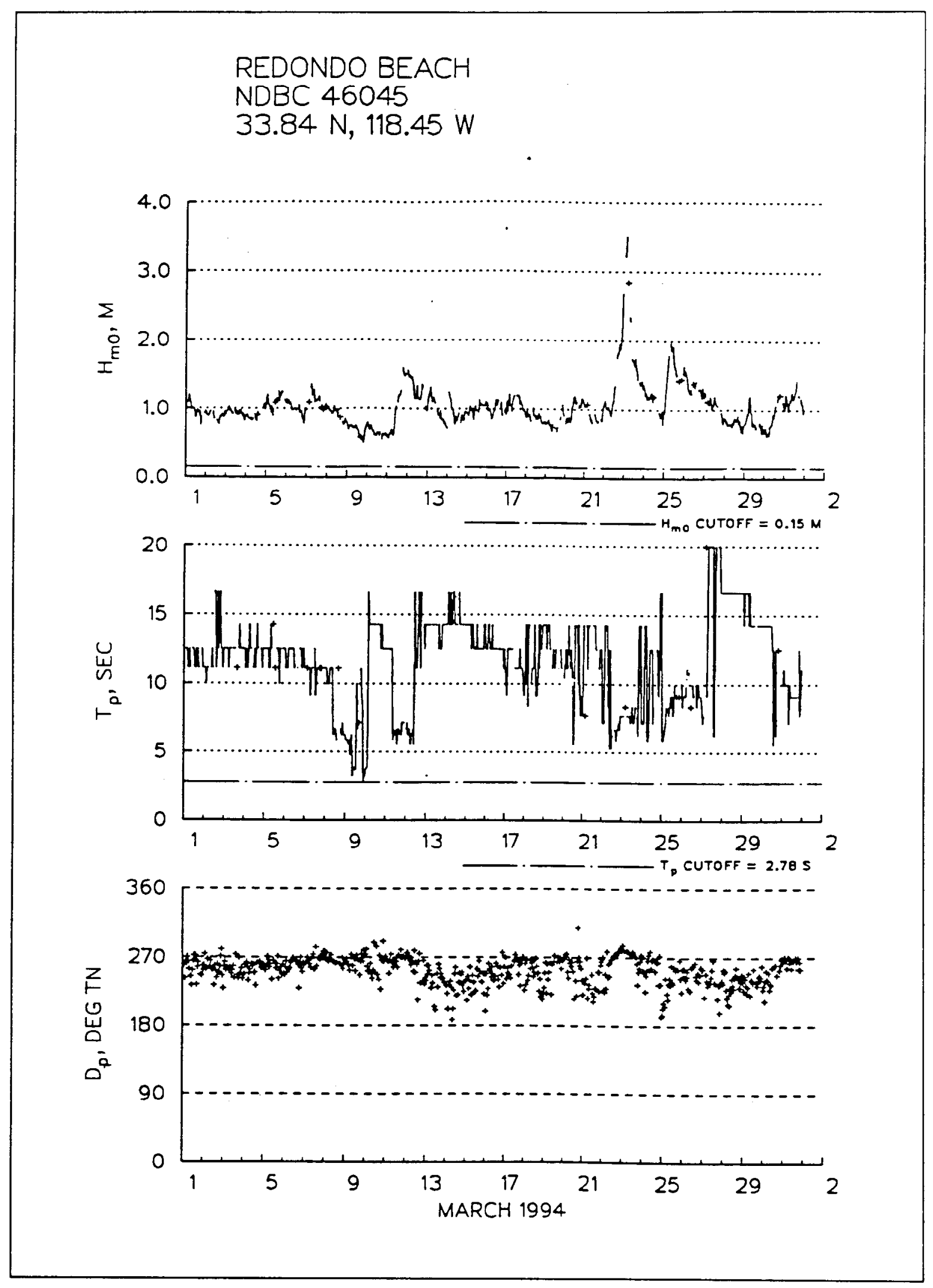

Figure J6. Time series plot for Redondo gage (NDBC 46045), March 1994, second deployment 


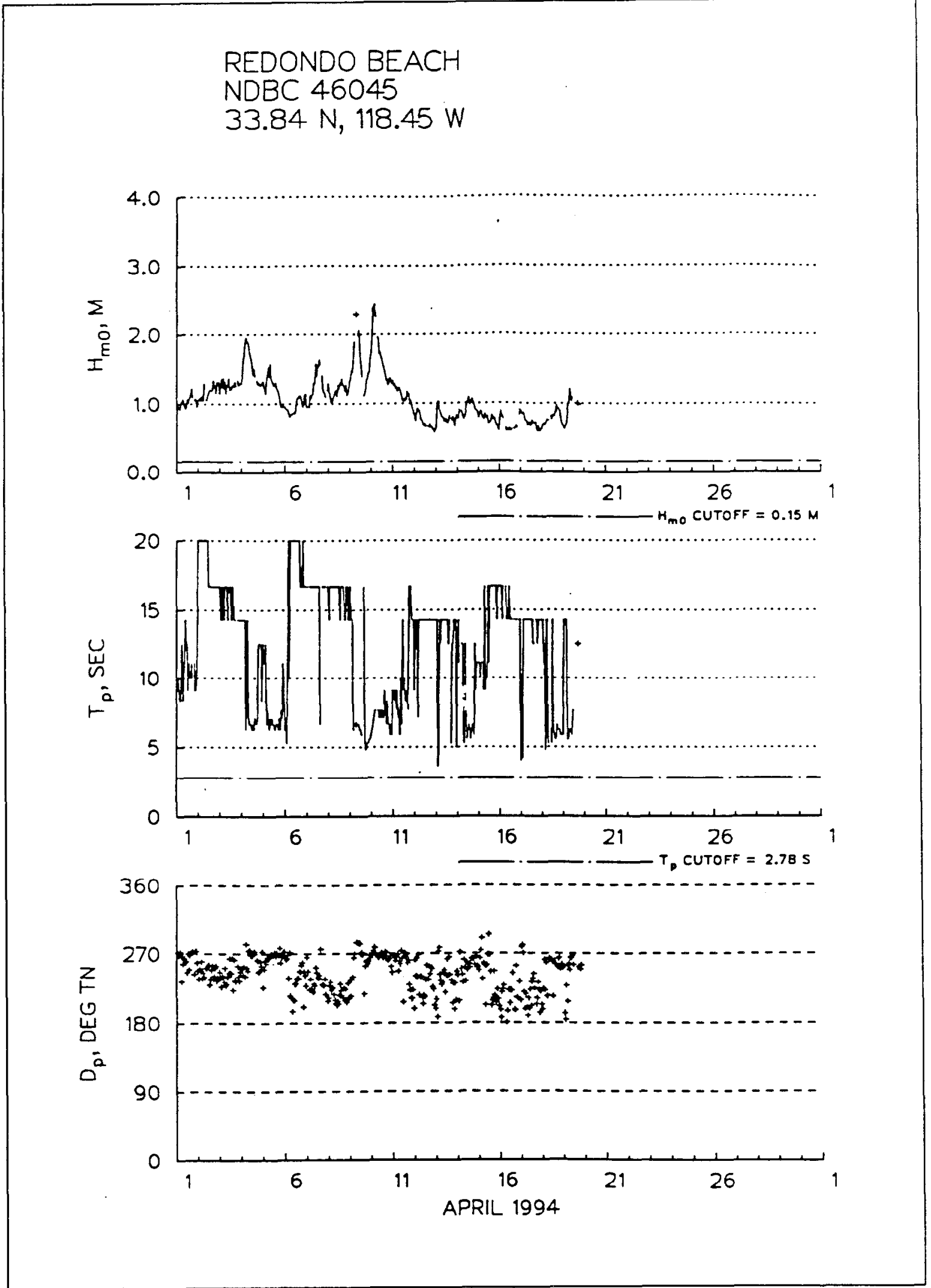

Figure J7. Time series plot for Redondo gage (NDBC 46045), April 1994, second deployment J8 


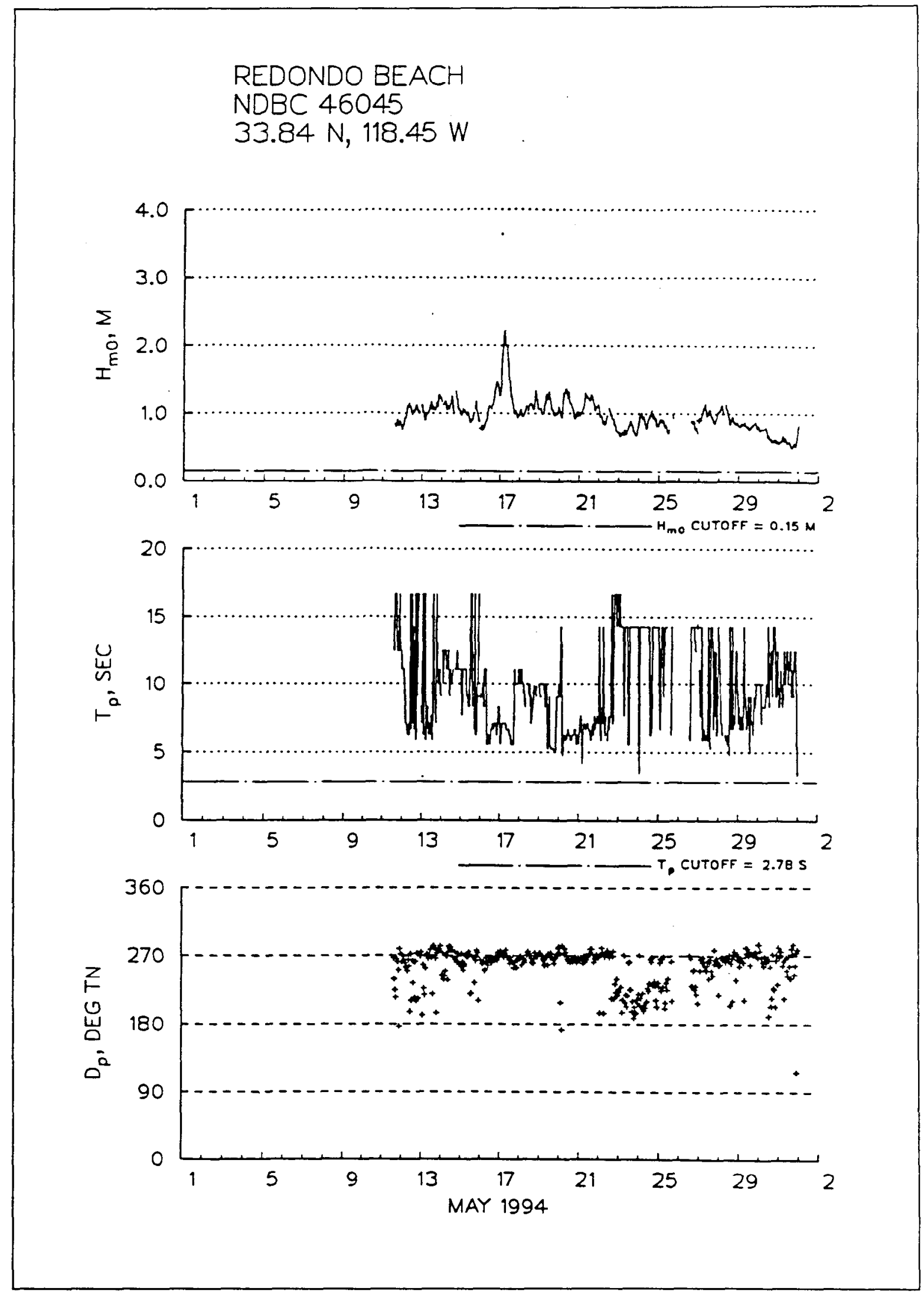

Figure J8. Time series plot for Redondo gage (NDBC 46045), May 1994, second deployment 
REDONDO BEACH

NDBC 46045

$33.84 \mathrm{~N}, 118.45 \mathrm{~W}$
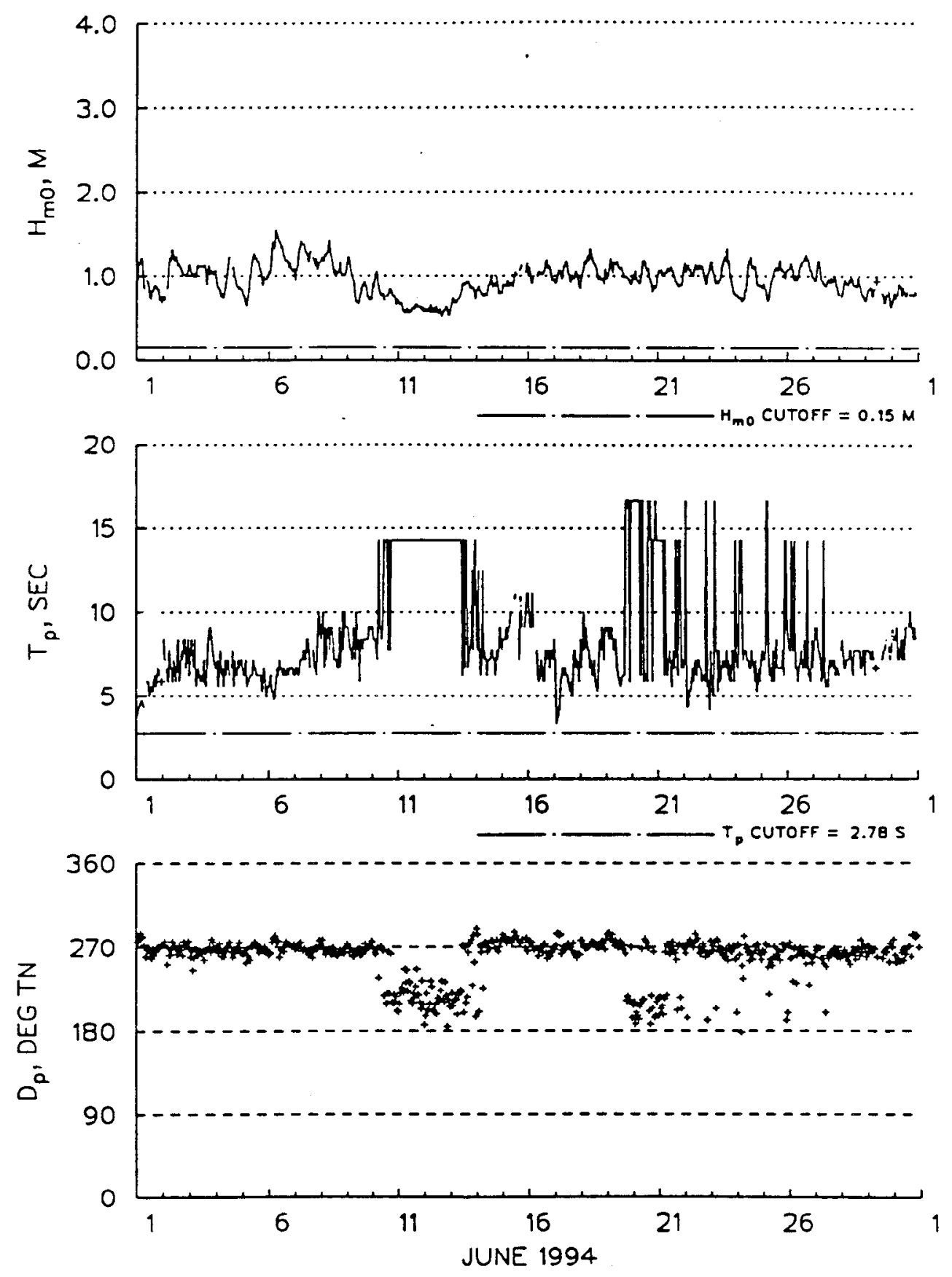

Figure J9. Time series plot for Redondo gage (NDBC 46045), June 1994, second deployment J10 


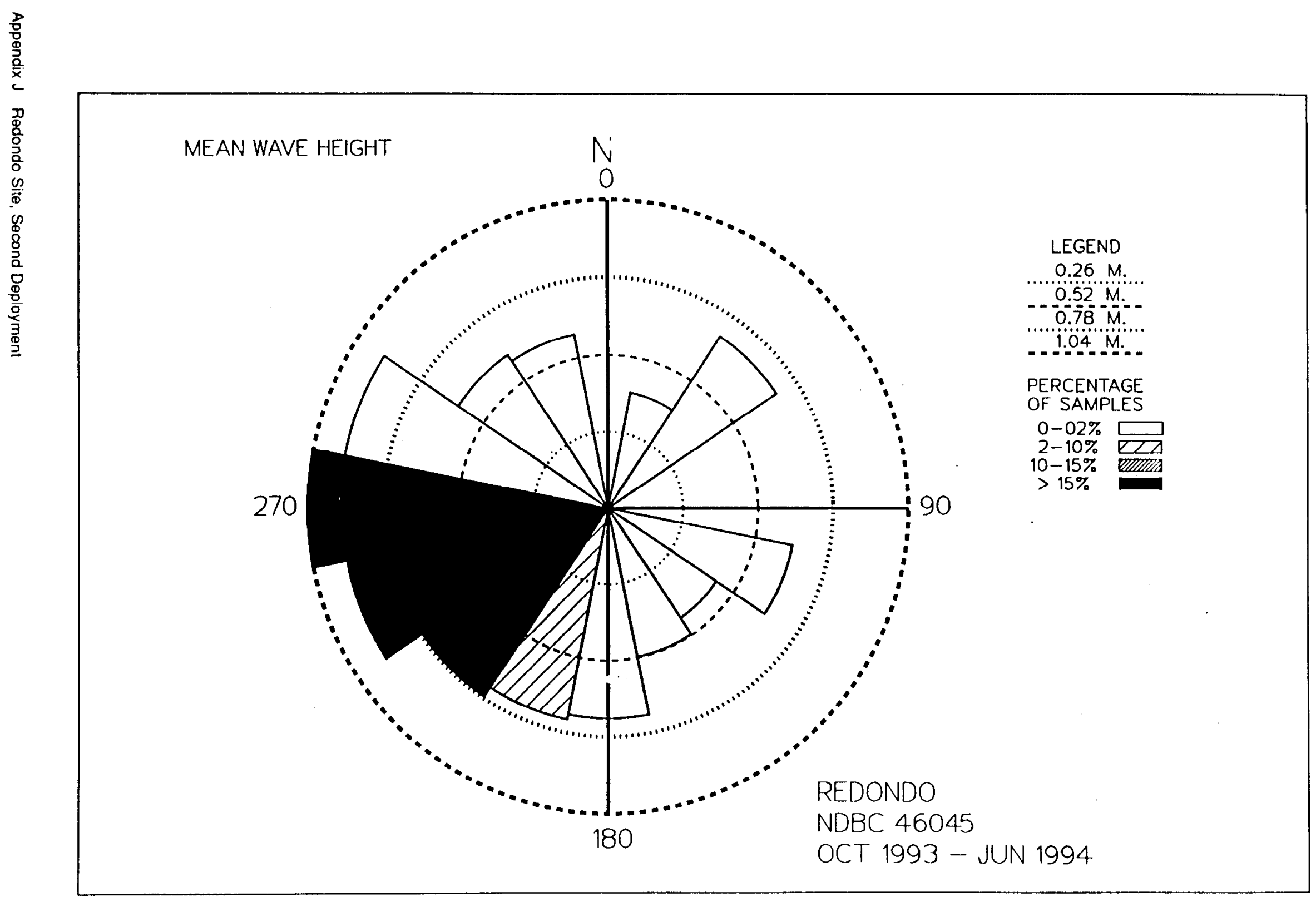




\section{Table J1}

Mean/Max Values for Redondo (NDBC 46045)

Second Deployment

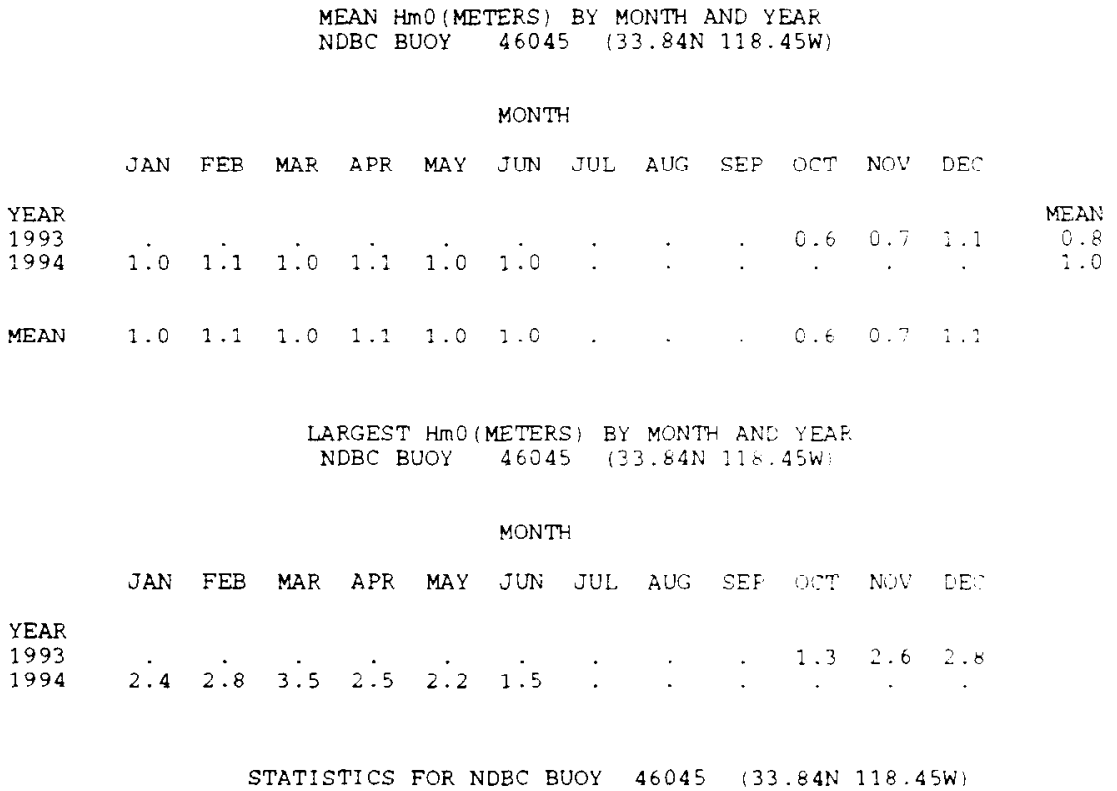

THE TP(SECONDS)ASSOC. WTTH THE LARGEST HMO=

THE PEAK DIRECTION (DEGREES) ASSOC. WITH THE LARGEST HMO= 


\section{Table J2 \\ Percent Occurrence for Redondo (NDBC 46045) \\ Second Deployment}

BUOY STATION $46045 \quad 33.84 \mathrm{~N} 318.4 \mathrm{~W}$ FOR ALL DIRECTIONS

PERCENT OCCURRENCE $(X 100)$ OF HEIGHT AND PERIOD

HEIGHT (METERS)

PEAK PER TODISECONDS I

TOTAL

$<6.96 .9-8.1-8.8-9.6-10.6-11.8-13.4-15.4-18.2$

$0.0-0.9$

$1.0-1 \cdot 9$

$2 \cdot 0-2 \cdot 9$

$4.0-4 \cdot 9$

$5.0-5.9$

$6.0-6.9$

$7.0-7.9$

$8.0-8.9$

$9.0-9.9$

$10.0+$

TOTAL

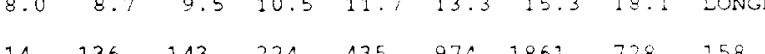

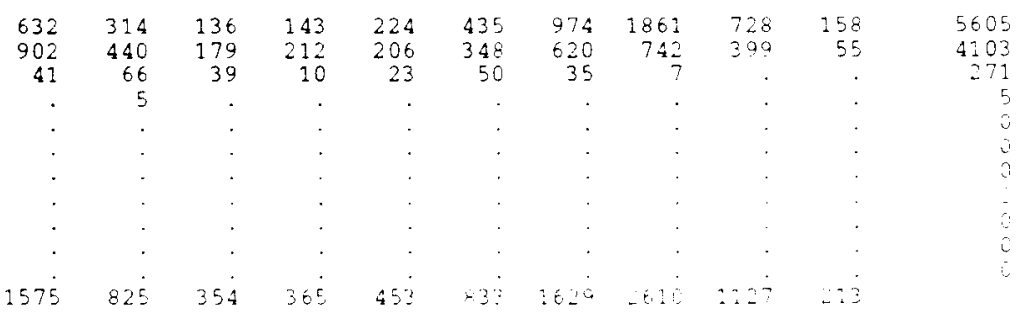

$\operatorname{MEAN} \operatorname{HMO}(\mathrm{M})=$

LARGEST HMO $(M)=3.5$

MEAN TP $(S E C)=12.6$ TOTAL CASES

556.2 


\section{Appendix K Catalina Ridge Site, Second Deployment}




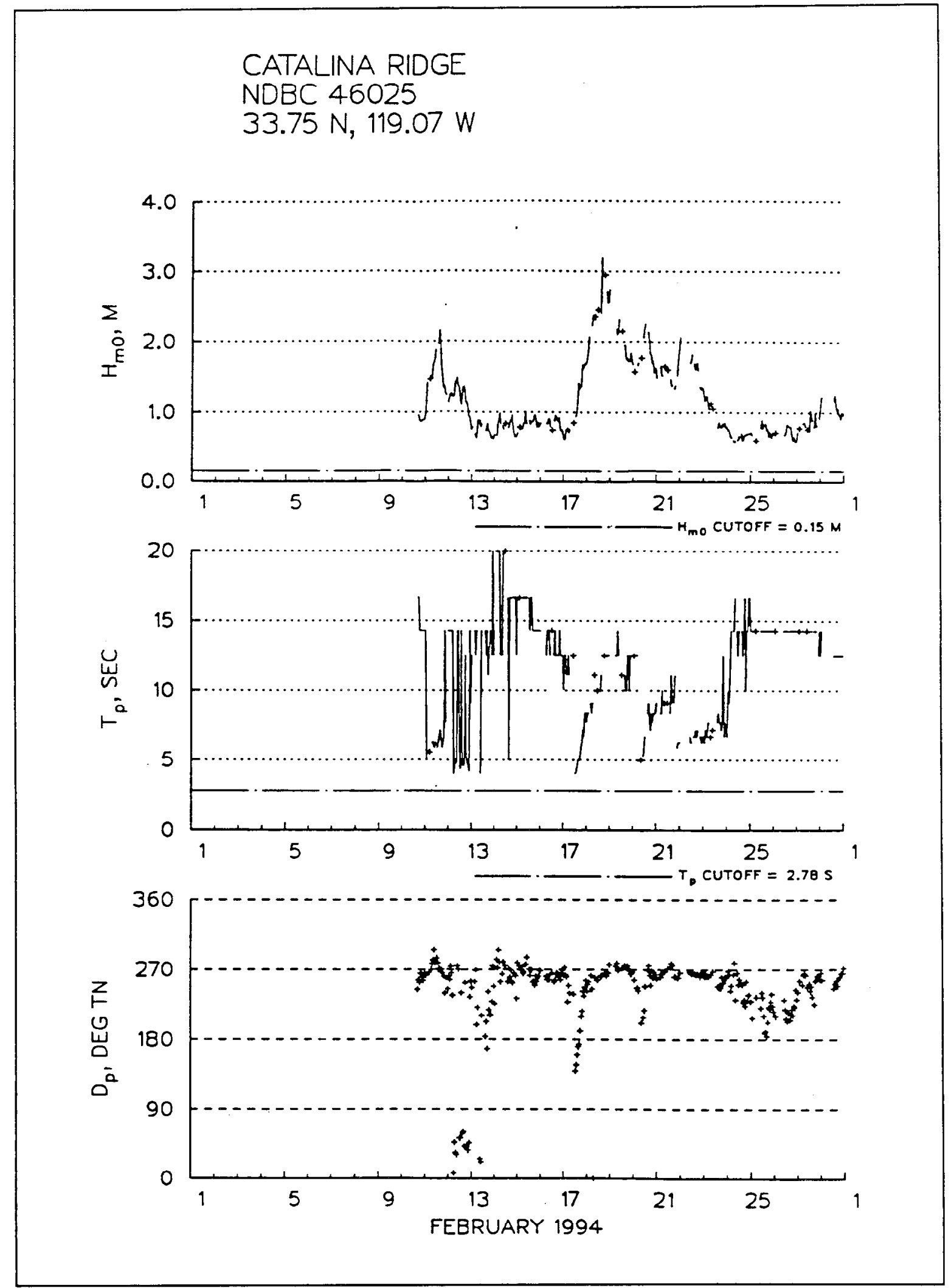

Figure K1. Time series plot for Catalina Ridge gage (NDBC 46025), February 1994, second deployment 


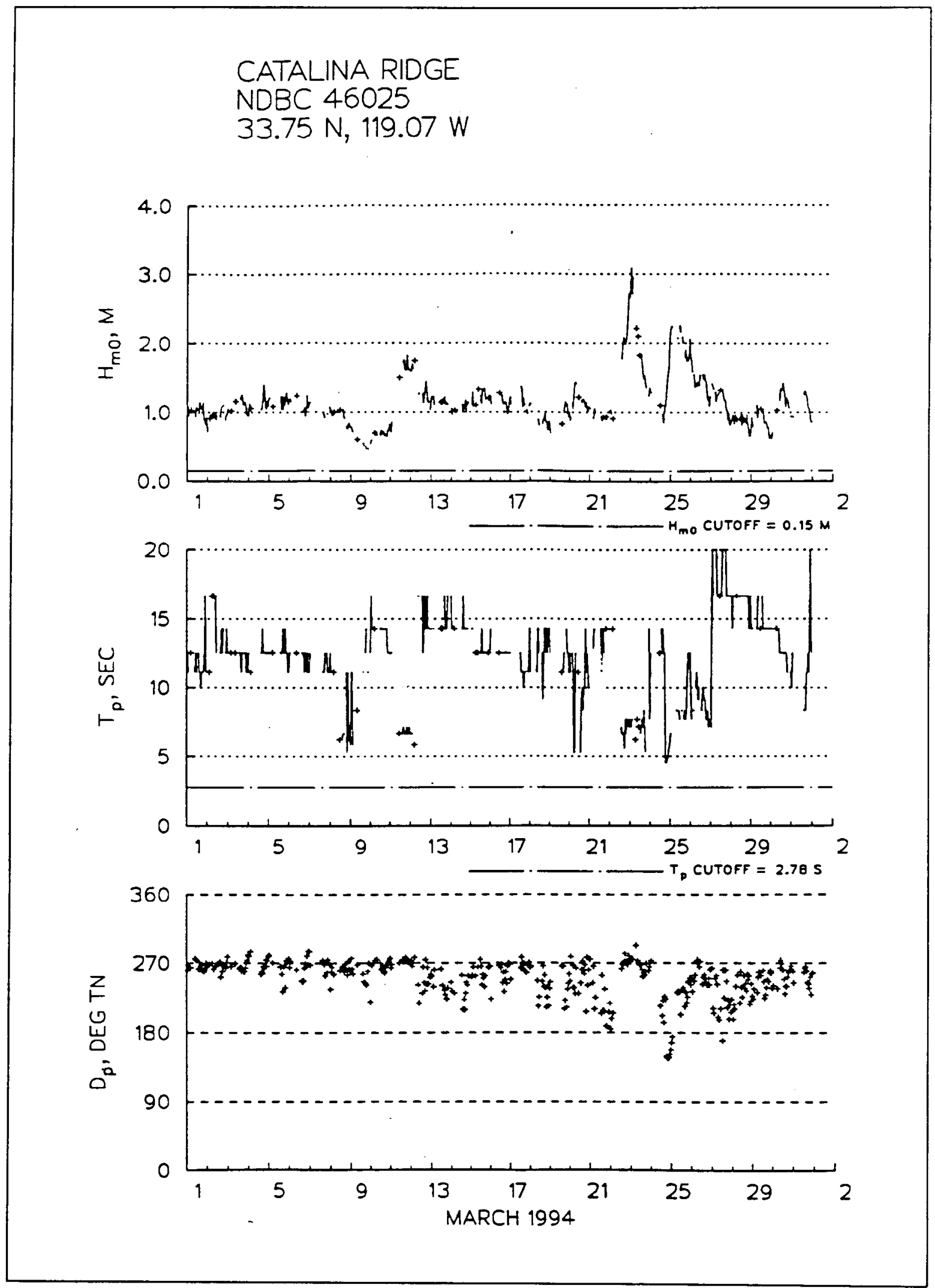

Figure K2. Time series plot for Catalina Ridge gage (NDBC 46025), March 1994, second deployment 


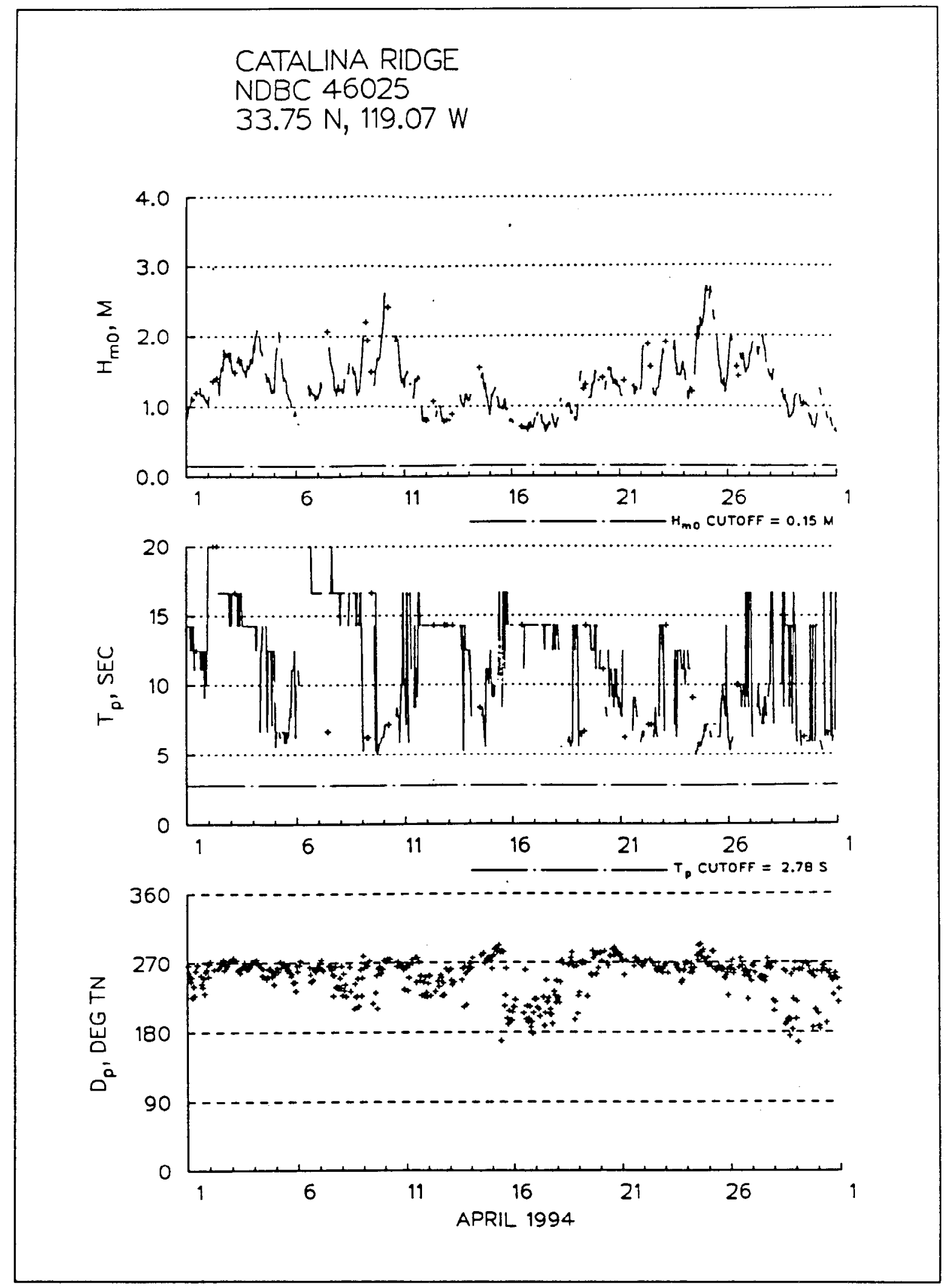

Figure K3. Time series plot for Catalina Ridge gage (NDBC 46025), April 1994, second deployment 


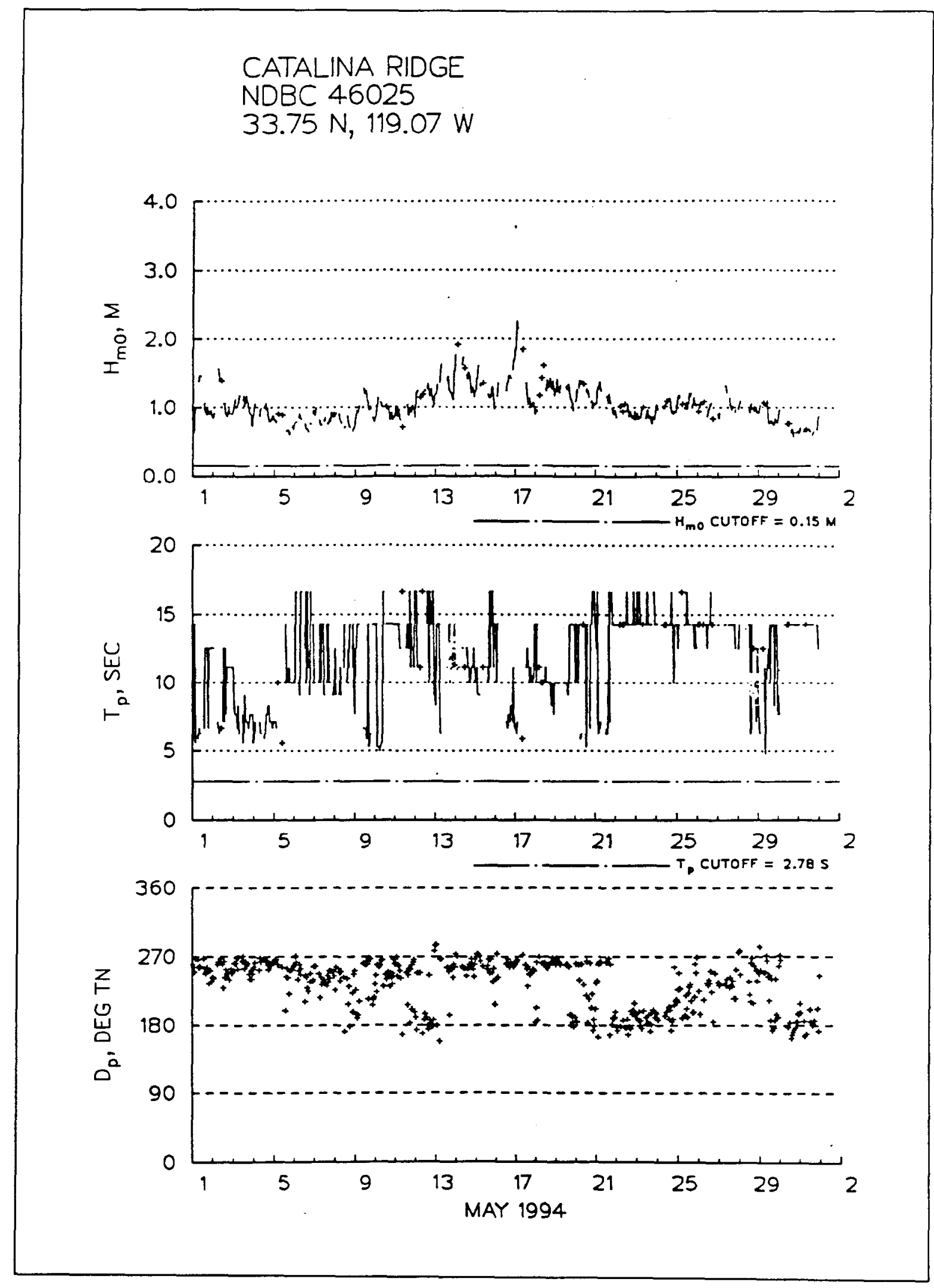

Figure K4. Time series plot for Catalina Ridge gage (NDBC 46025), May 1994, second deployment 


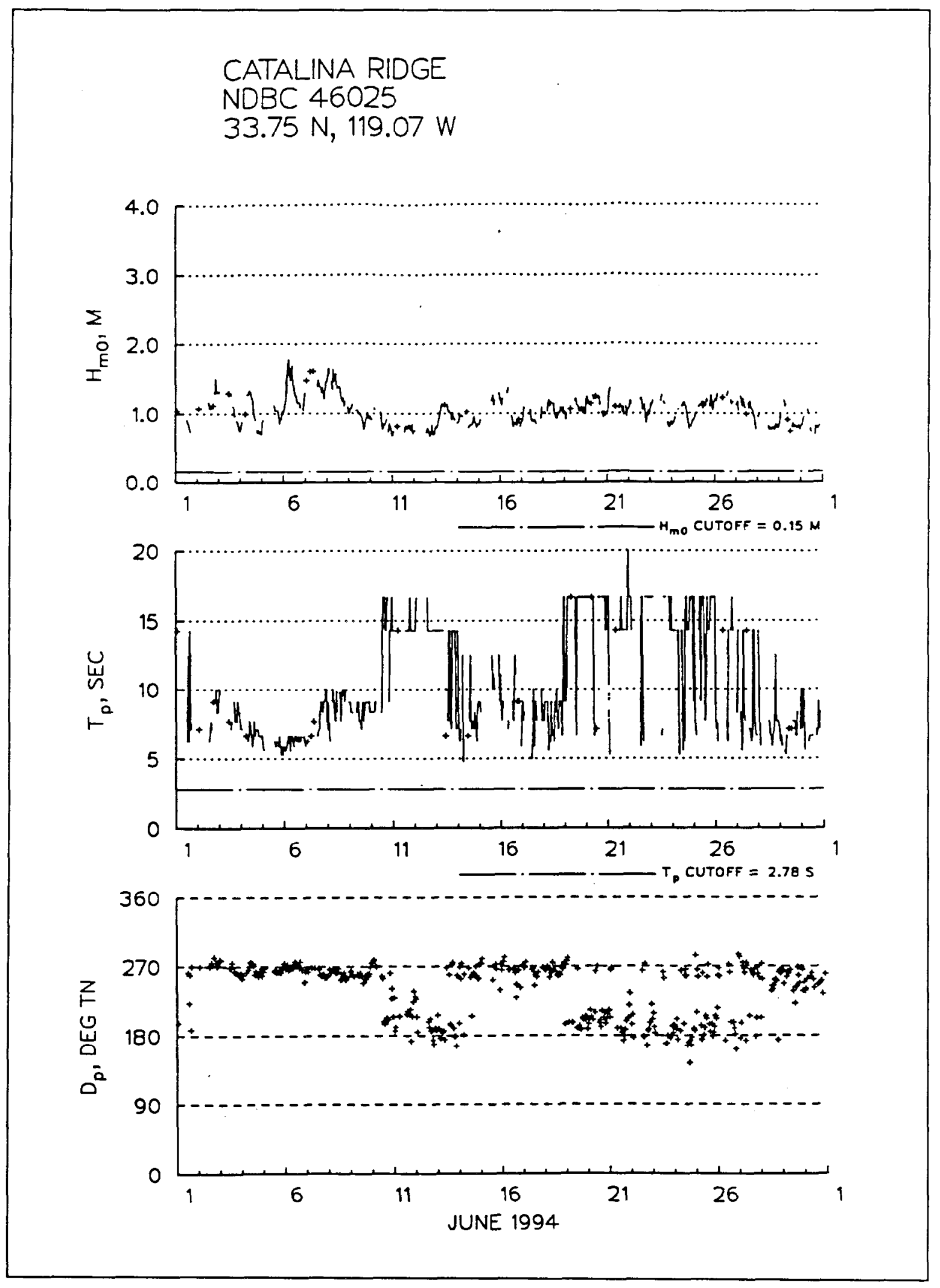

Figure K5. Time series plot for Catalina Ridge gage (NDBC 46025), June 1994, second deployment 


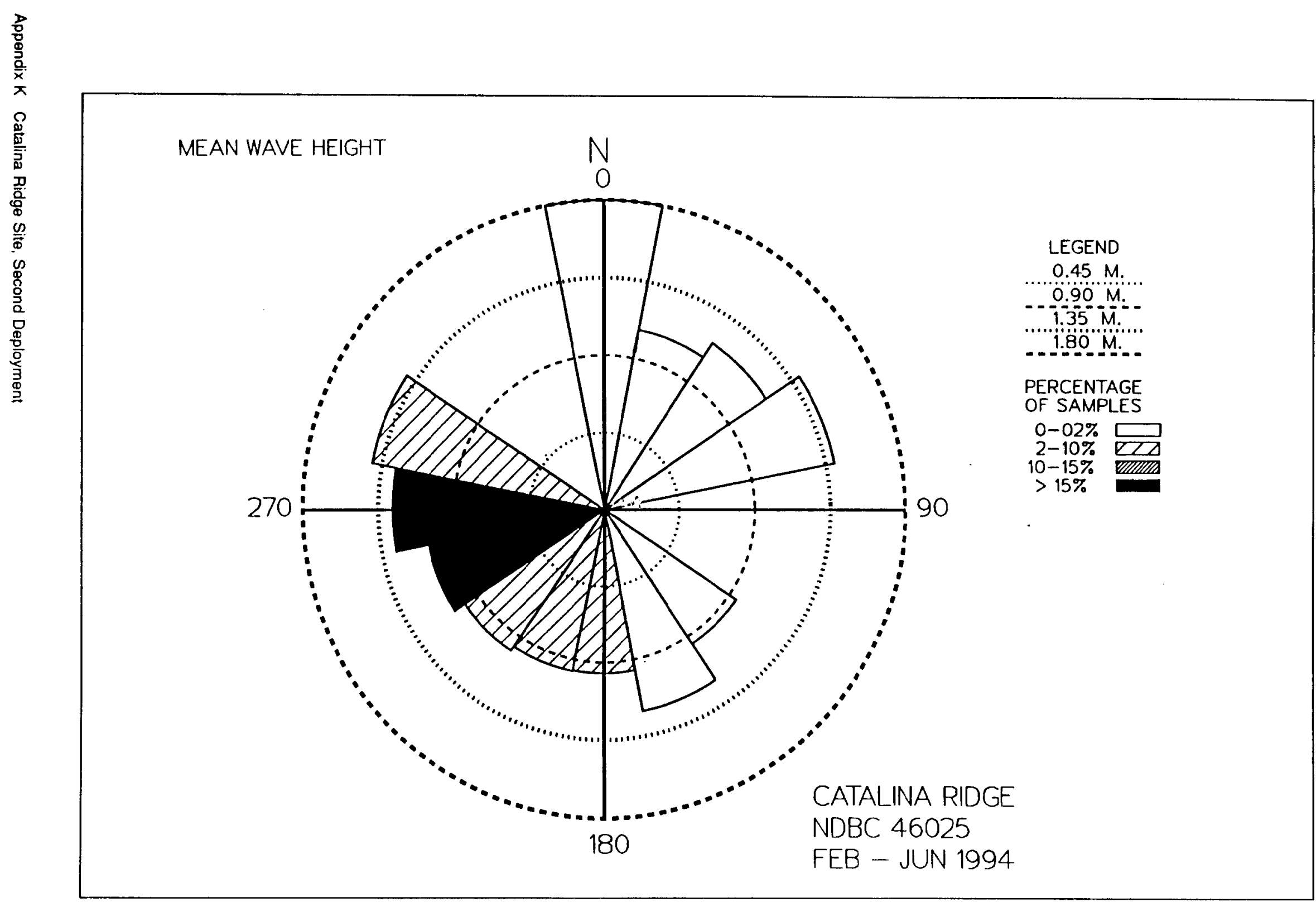


Table K1

Mean/Max Values for Catalina Ridge (NDBC 46025)

Second Deployment

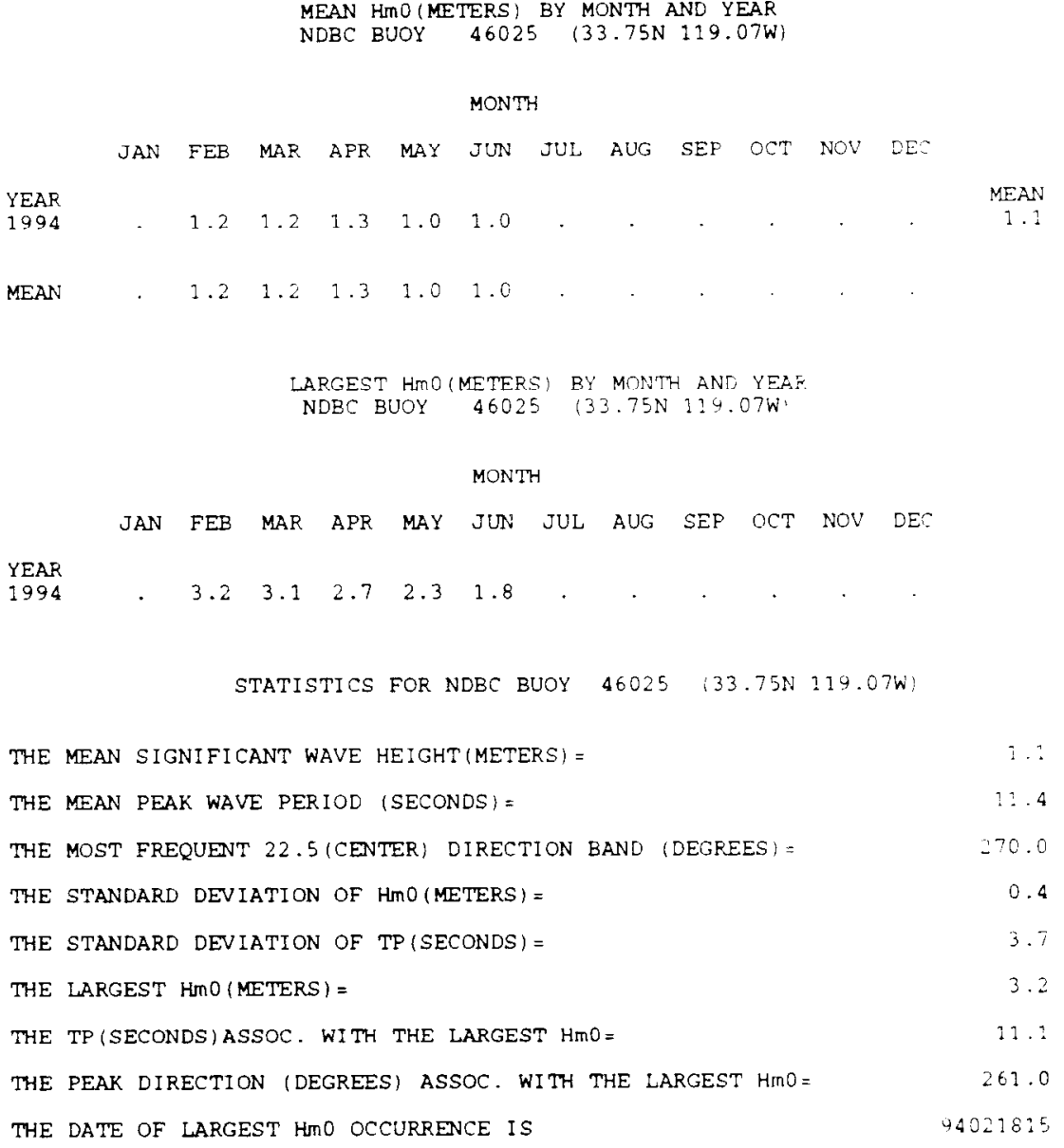

MEAN

THE MEAN SIGNIFICANT WAVE HEIGHT (METERS) =

THE MEAN PEAK WAVE PERIOD (SECONDS)=

THE MOST FREQUENT 22.5 (CENTER) DIRECTION BAND (DEGREES) =

THE STANDARD DEVIATION OF HMO(METERS) =

270.0

THE STANDARD DEVIATION OF TP(SECONDS $)=$

THE LARGEST HMO (METERS) $=$

THE TP(SECONDS) ASSOC. WITH THE LARGEST HMO=

THE PEAK DIRECTION (DEGREES) ASSOC. WITH THE LARGEST HIO = 


\section{Table K2 \\ Percent Occurrence for Catalina Ridge (NDBC 46025) \\ Second Deployment}

BUOY STATION $4602533.75 \mathrm{~N} 119.07 \mathrm{~W}$ FOR ALL OIRECTIONS
FEBRUARY $1994-$ JUNE 1994

PERCENT OCCURRENCE $(X 100)$ OF HEIGHT AND PERIOD

HEIGHT (METERS)

PEAK PERIOD(SECONOS)

TOTAL

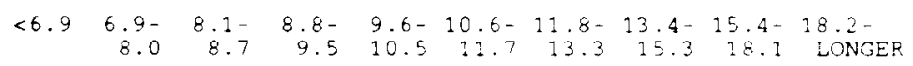

$0.0-0.9$

1. $0-1.9$

$2 \cdot 0-2 \cdot 9$

$3.0-3.9$

$4.0-4.9$

$5.0-5.9$

$6.0-6.9$

$7.0-7.9$

$8.0-8.9$

$9.0-9.9$

$10.0+$

TOTAL

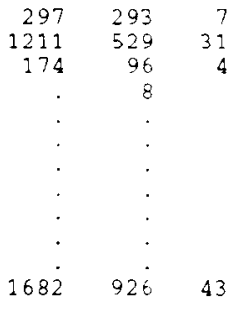

MEAN $\operatorname{HmO}\{M=1$.

MEAN TP $(S E C)=11.4$ TOTAL CASES

2286 


\section{Appendix L Additional NDBC Time Series Plots}




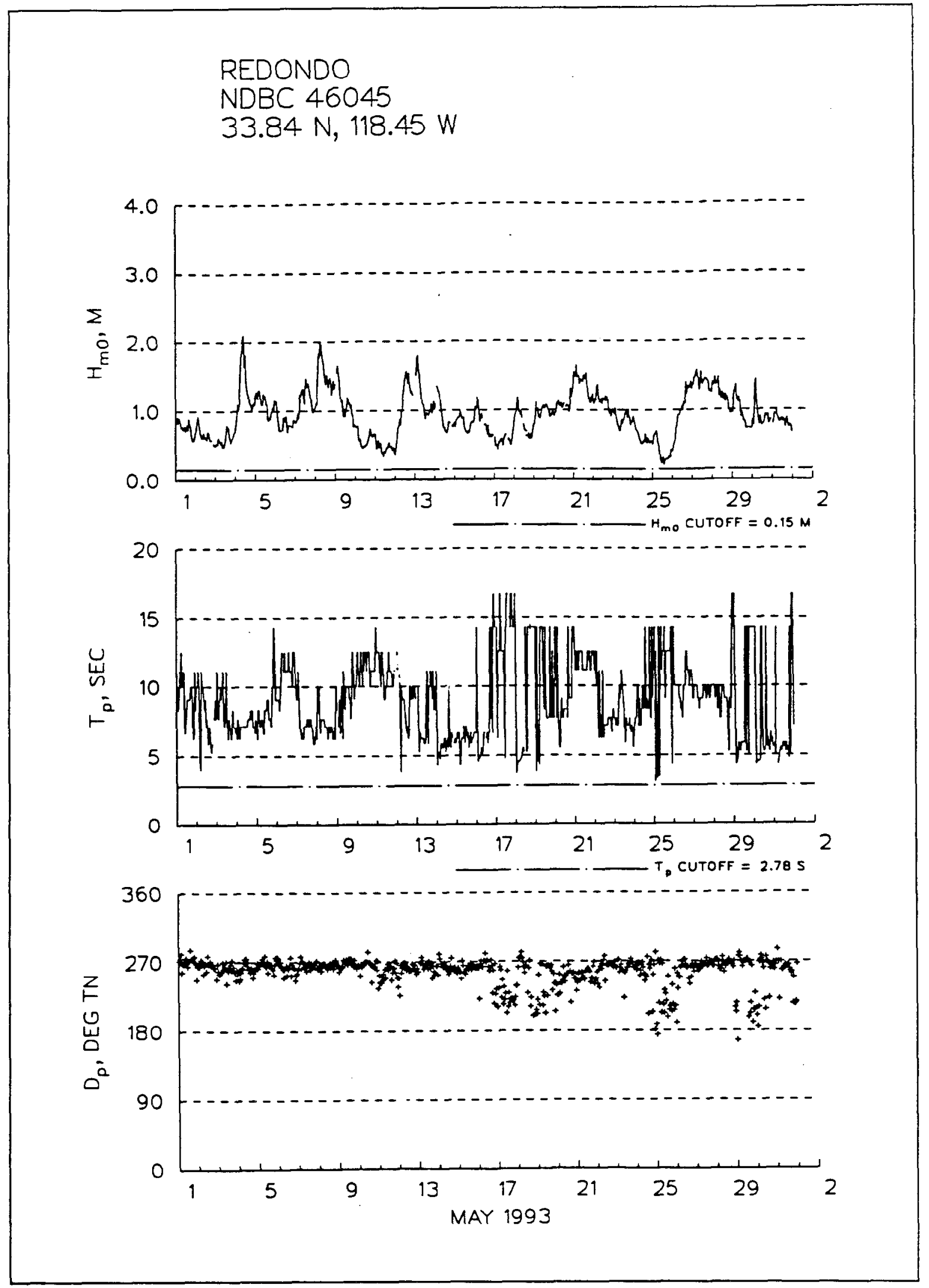

Figure L1. Redondo (NDBC 46045), May 1993 
REDONDO

NDBC 46045

$33.84 \mathrm{~N}, 118.45 \mathrm{~W}$
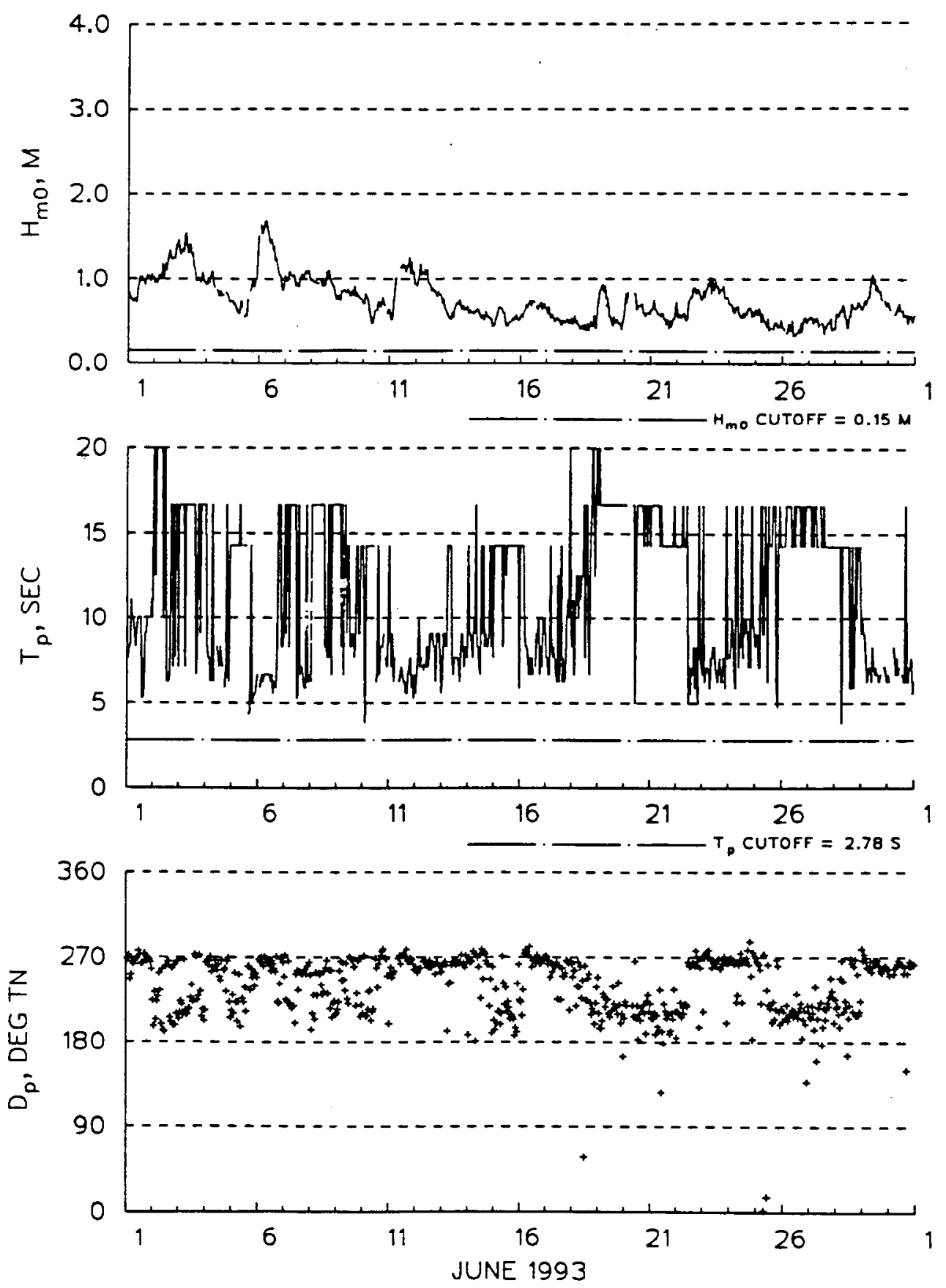

Figure L2. Redondo (NDBC 46045), June 1993 
REDONDO

NDBC 46045

$33.84 \mathrm{~N}, 118.45 \mathrm{~W}$
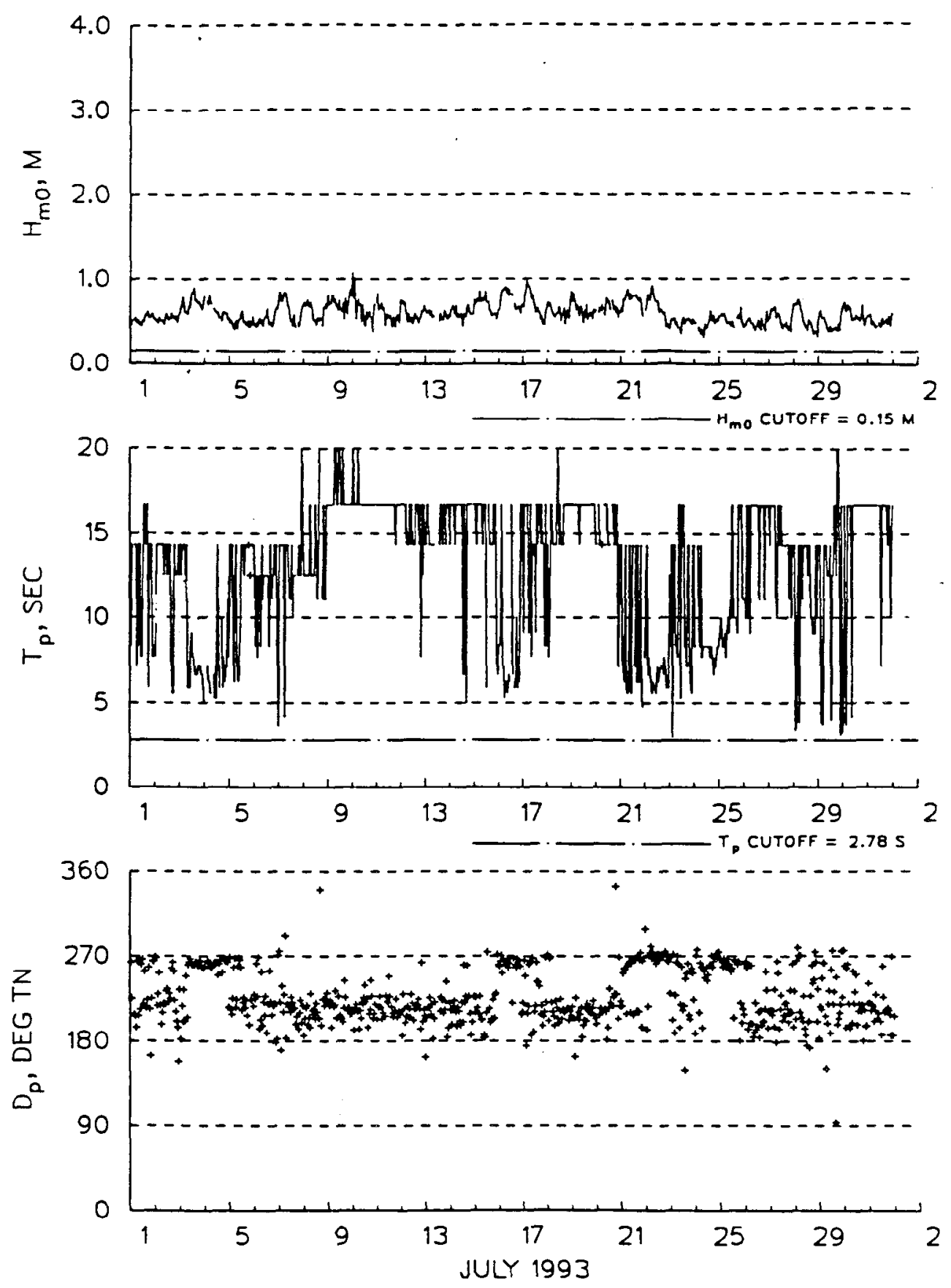

Figure L3. Redondo (NDBC 46045), July 1993 


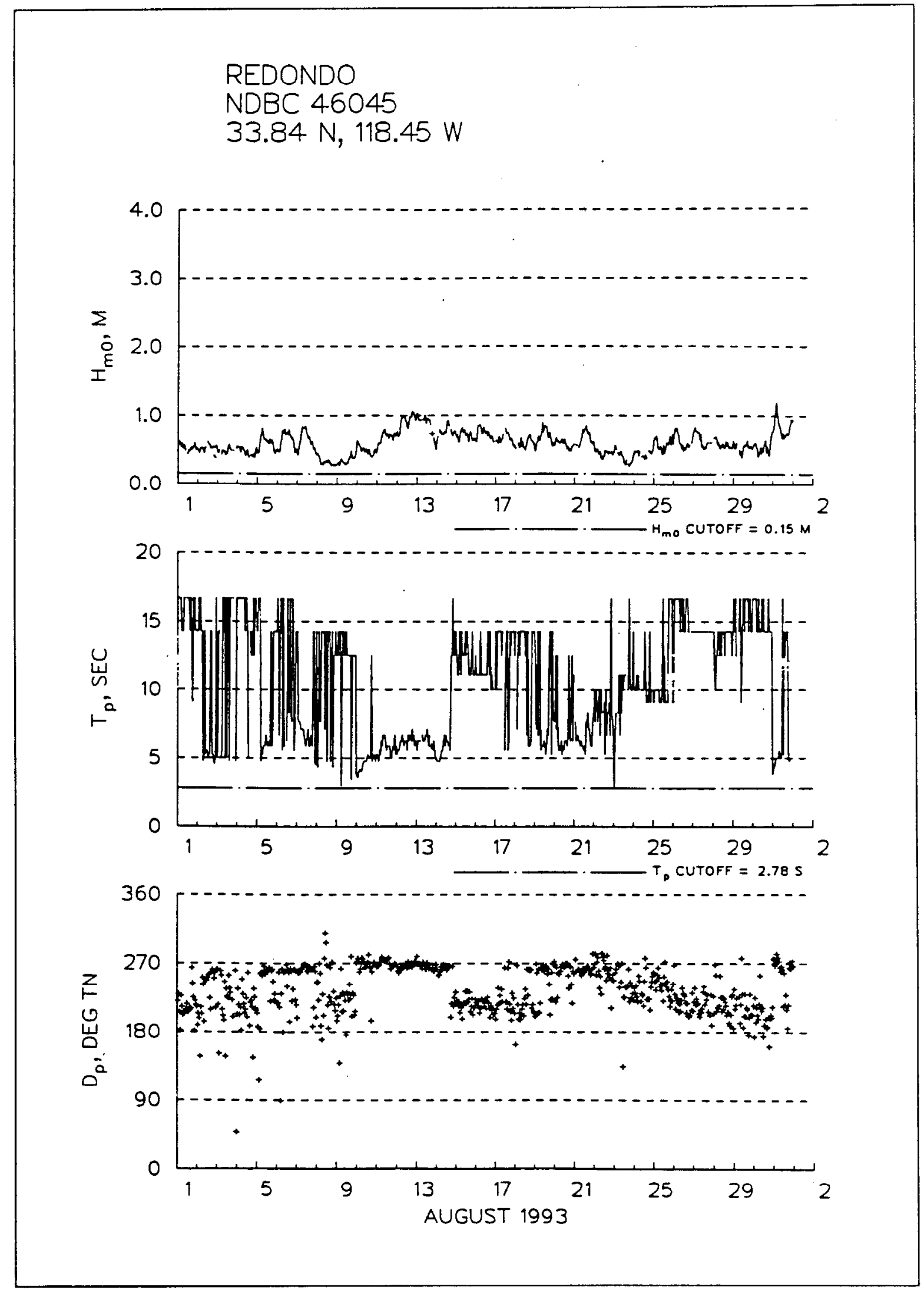

Figure L4. Redondo (NDBC 46045), August 1993 


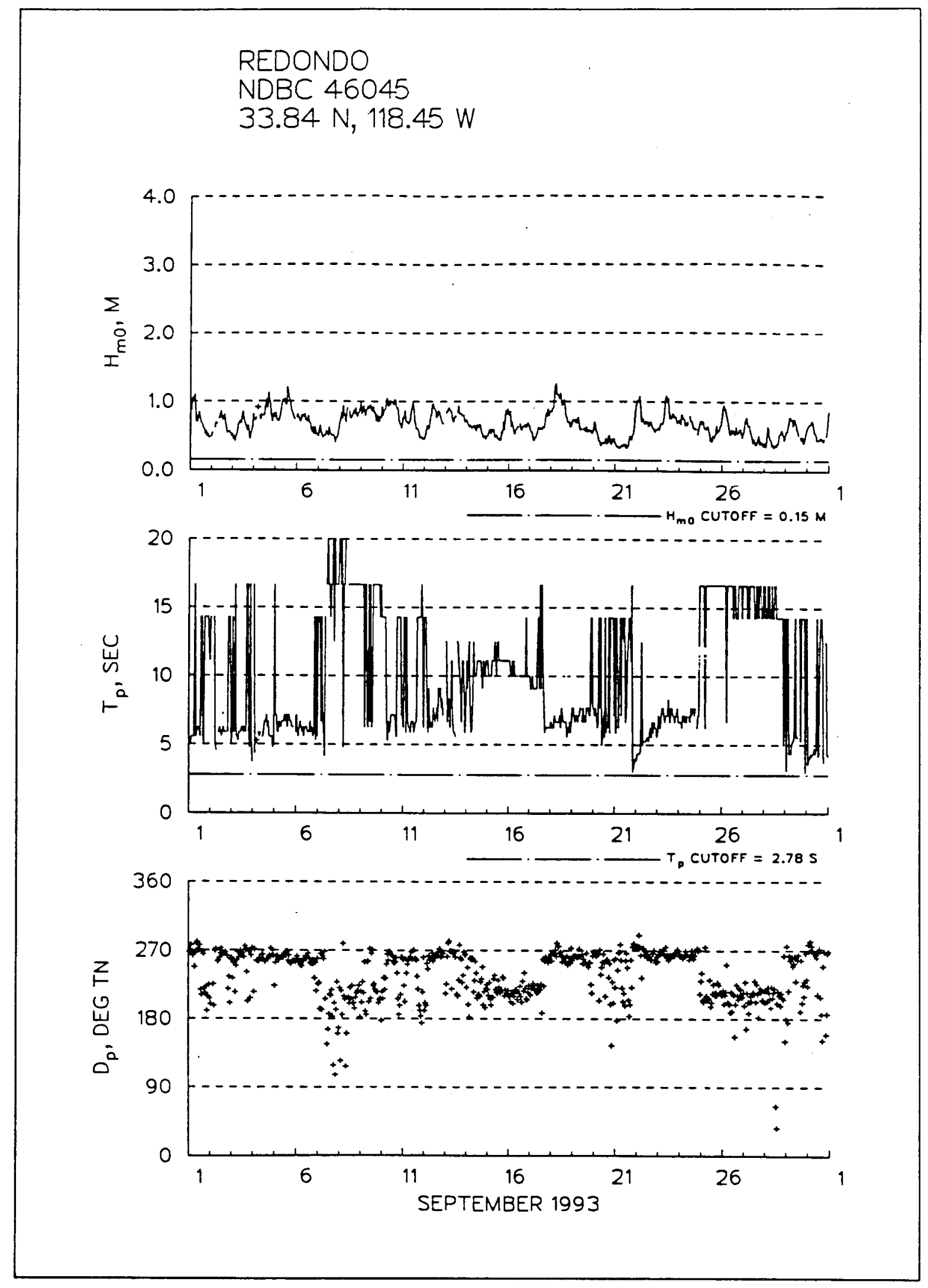

Figure L5. Redondo (NDBC 46045), September 1993 


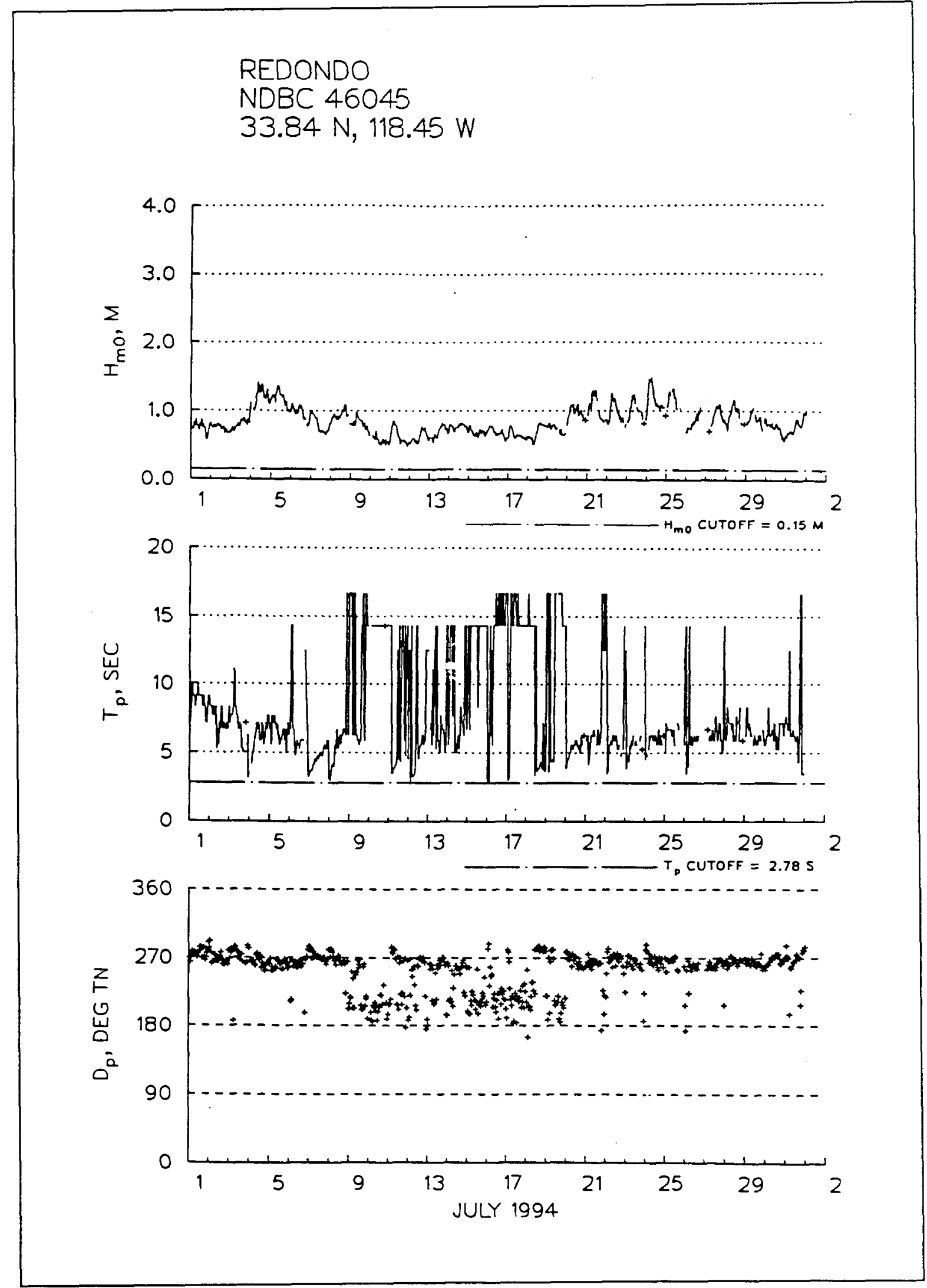

Figure L6. Redondo (NDBC 46045), July 1994 


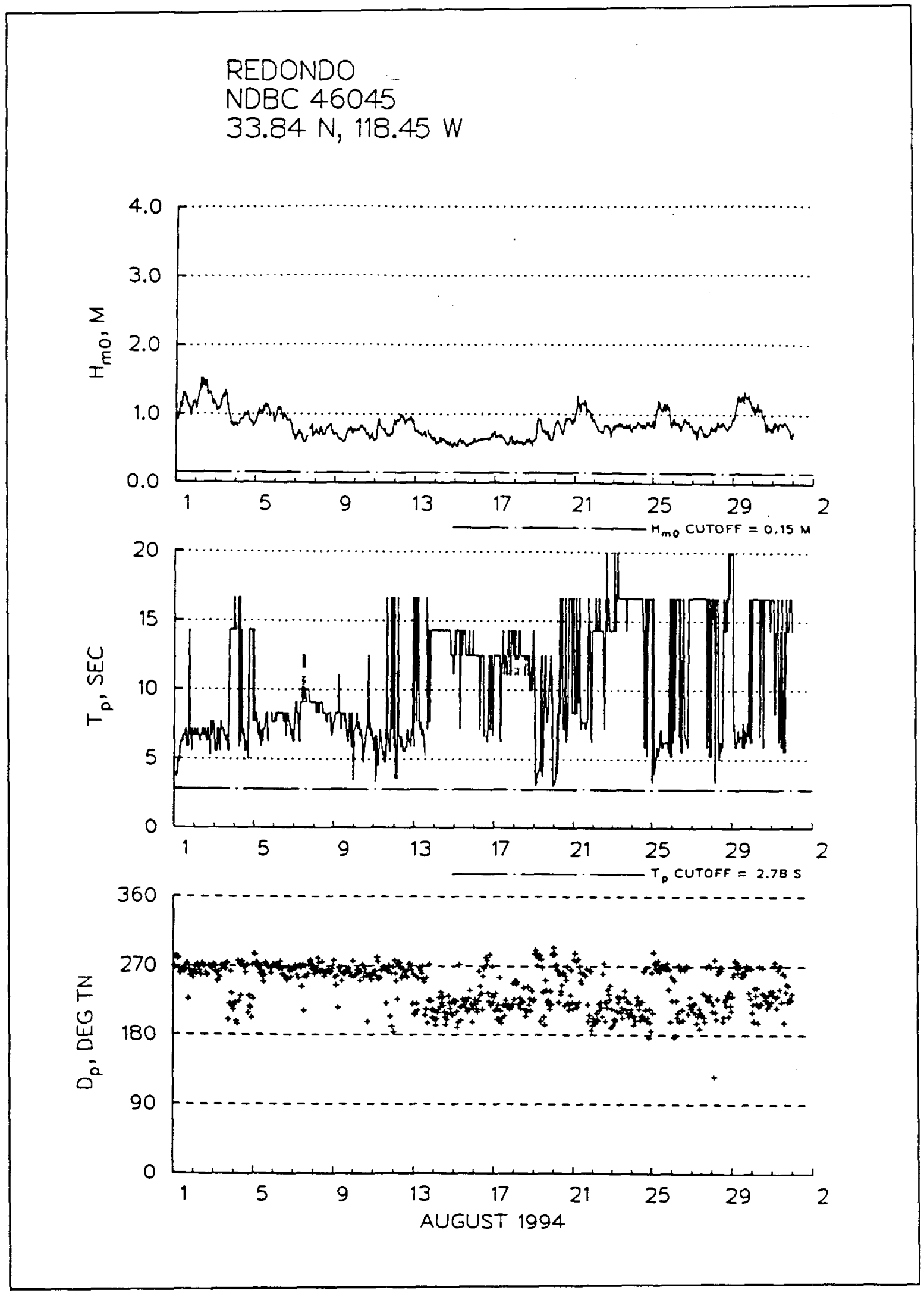

Figure L7. Redondo (NDBC 46045), August 1994 
REDONDO

NDBC 46045

$33.84 \mathrm{~N}, 118.45 \mathrm{~W}$
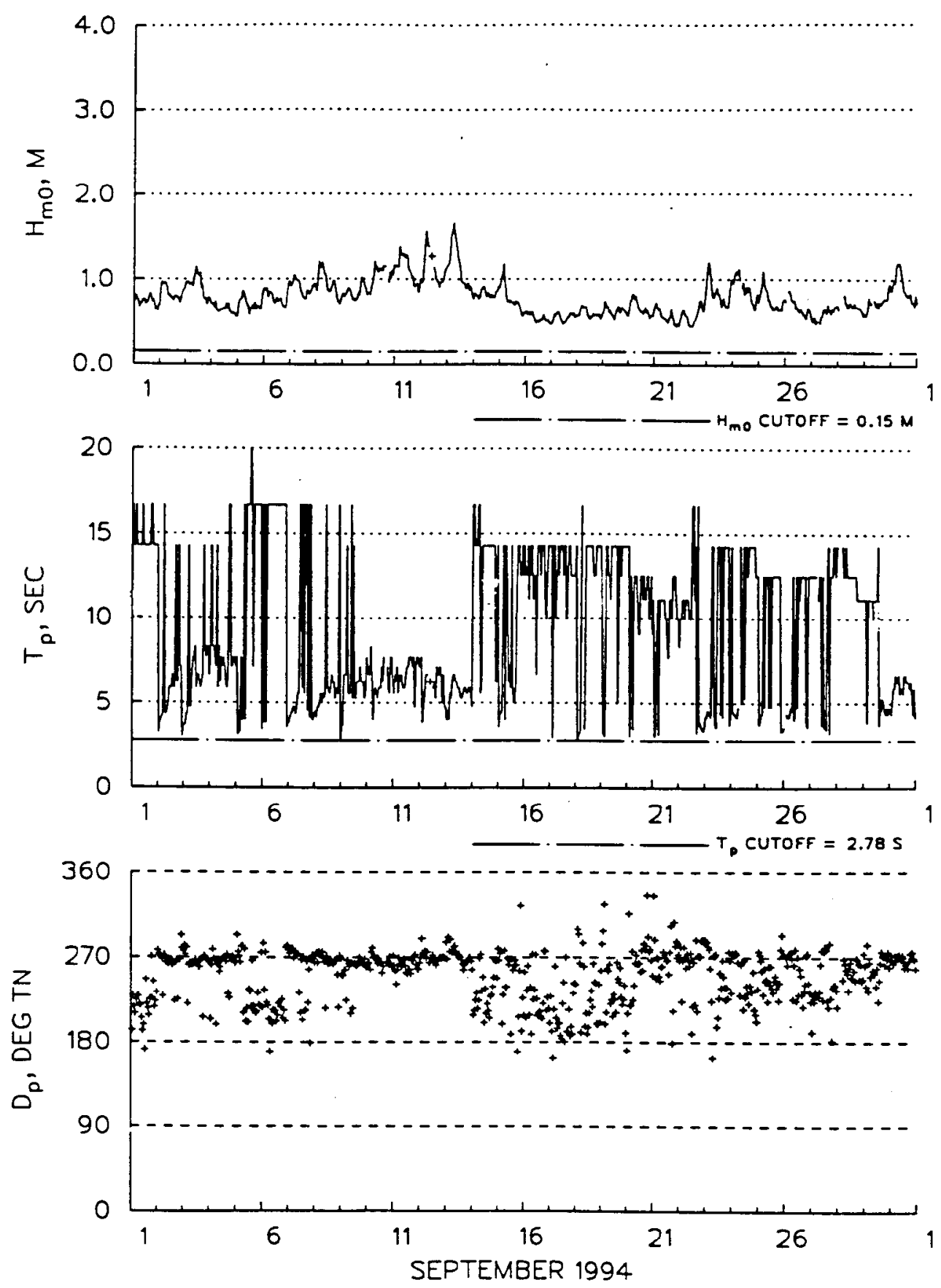

Figure L8. Redondo (NDBC 46045), September 1994 
CATALINA RIDGE

NDBC 46025

$33.75 \mathrm{~N}, 119.07 \mathrm{~W}$
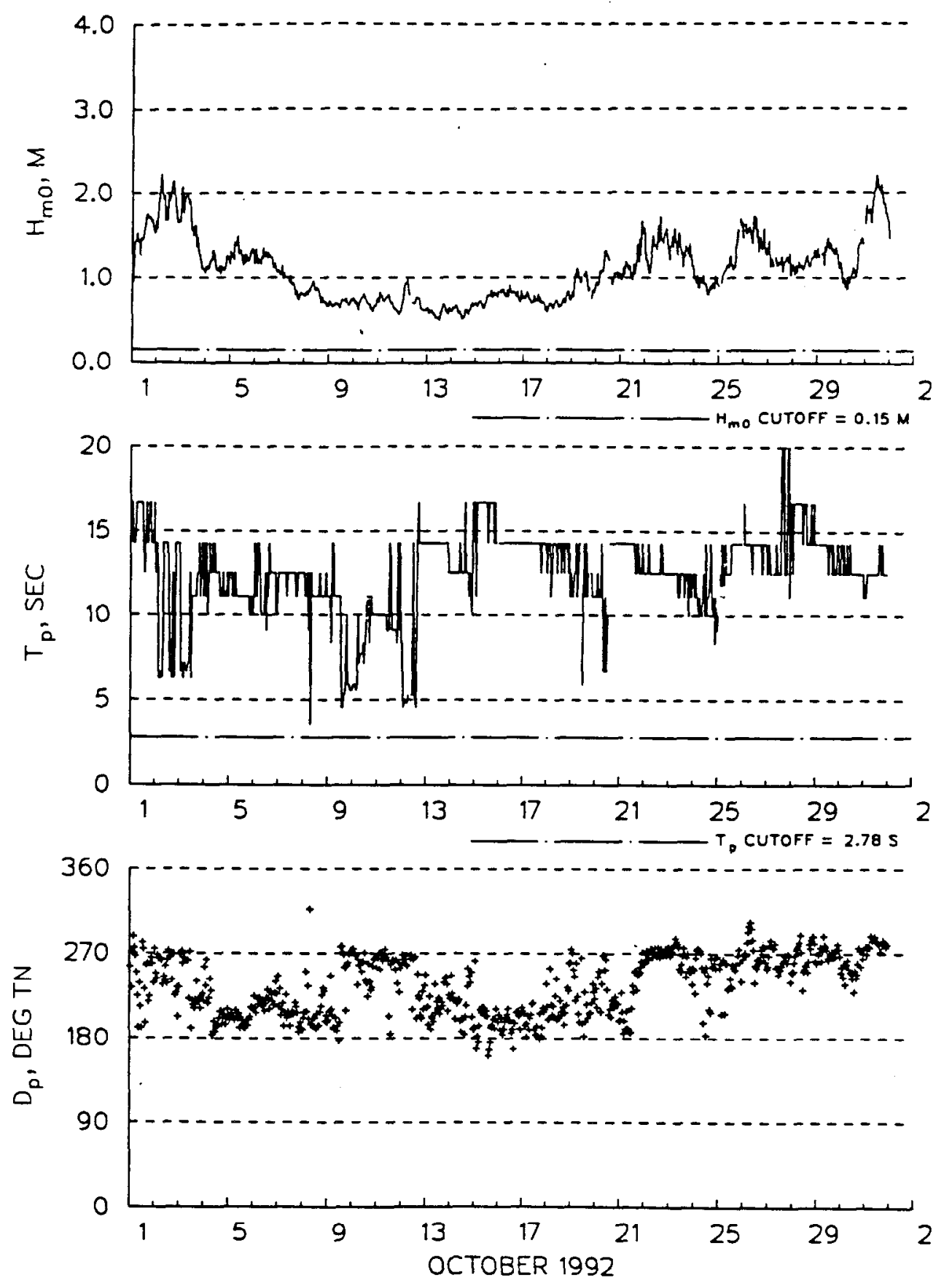

Figure L9. Catalina Ridge (NDBC 46025), October 1992 


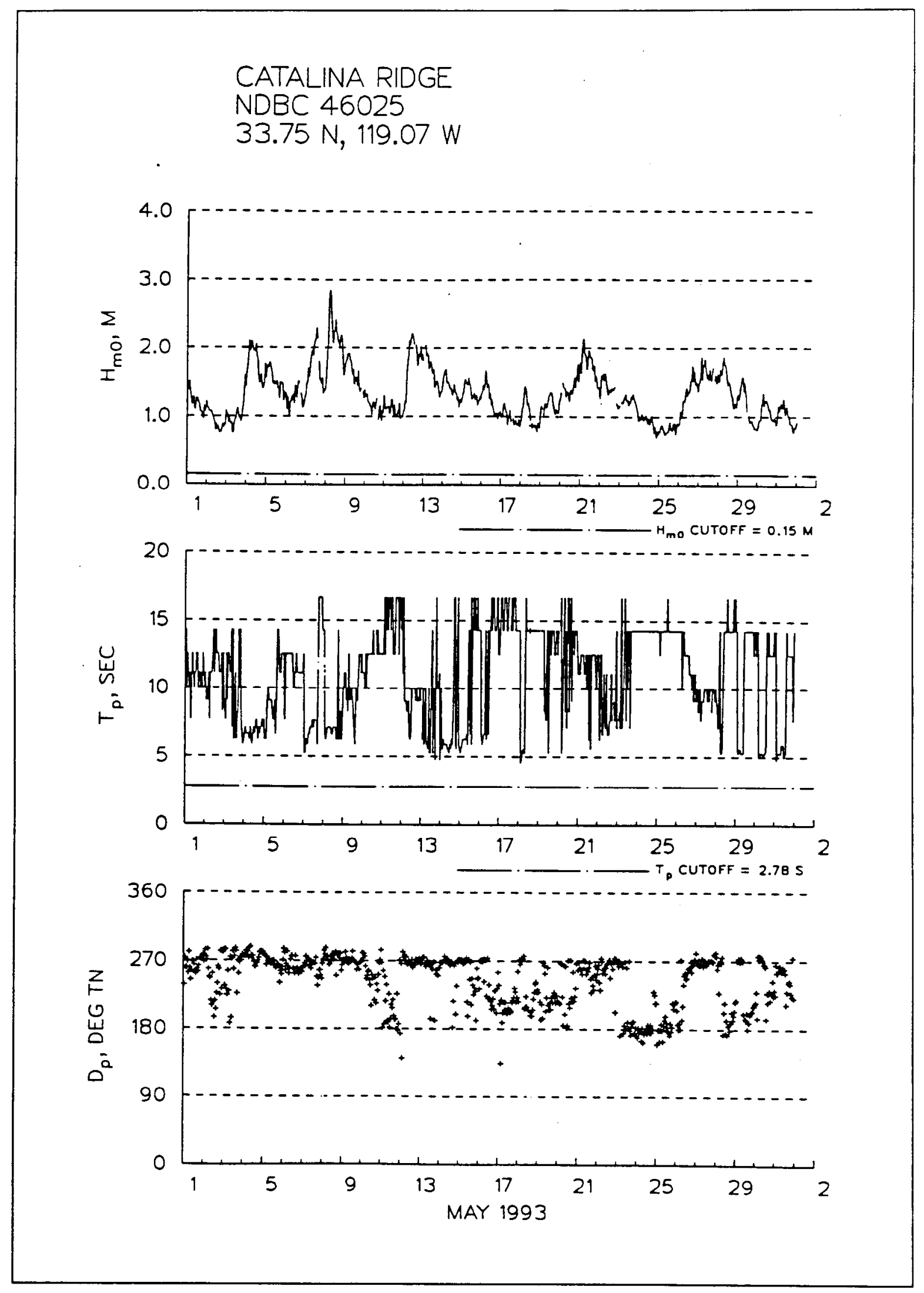

Figure L10. Catalina Ridge (NDBC 46025), May 1993 


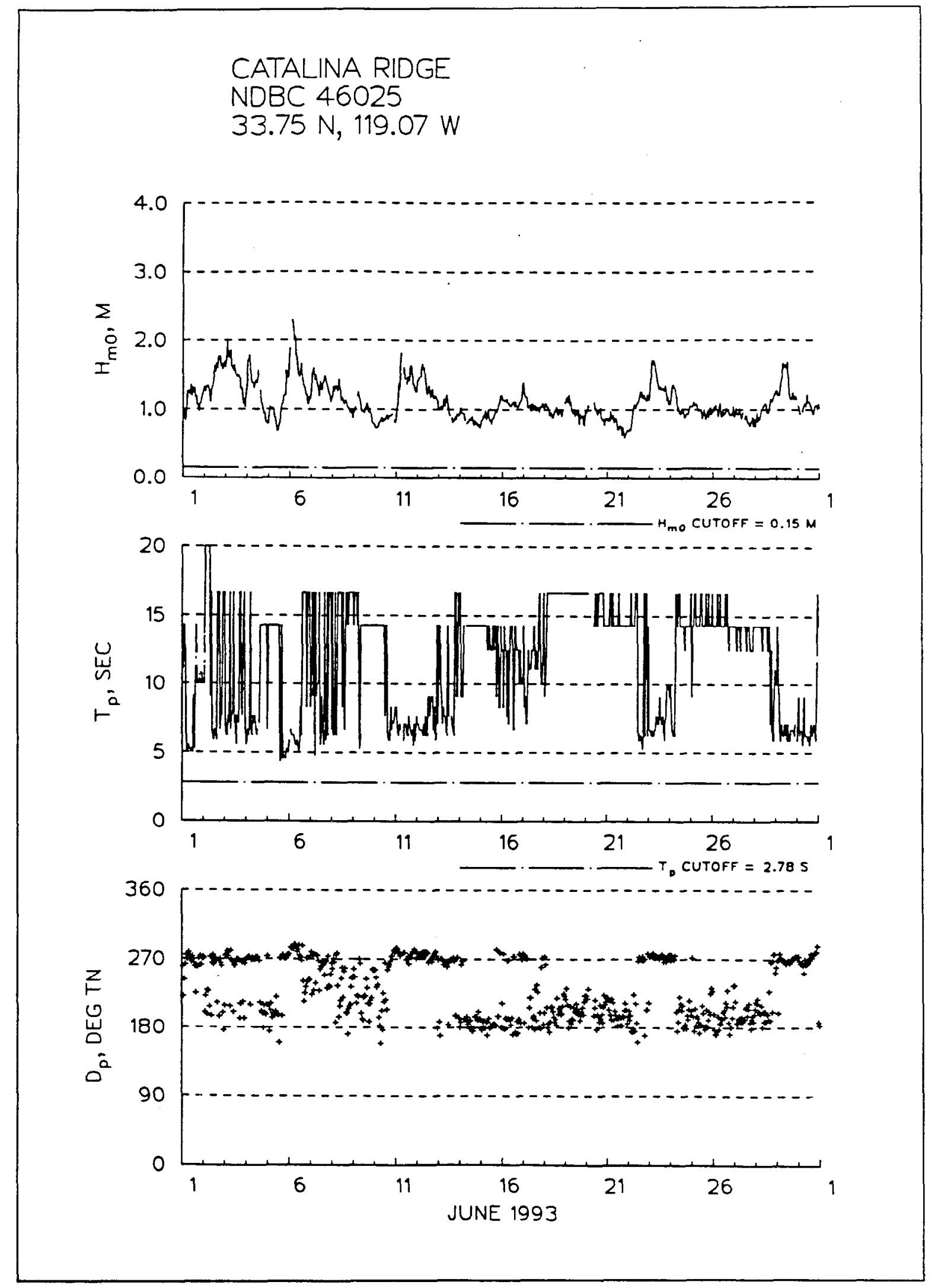

Figure L11. Catalina Ridge (NDBC 46025), June 1993 


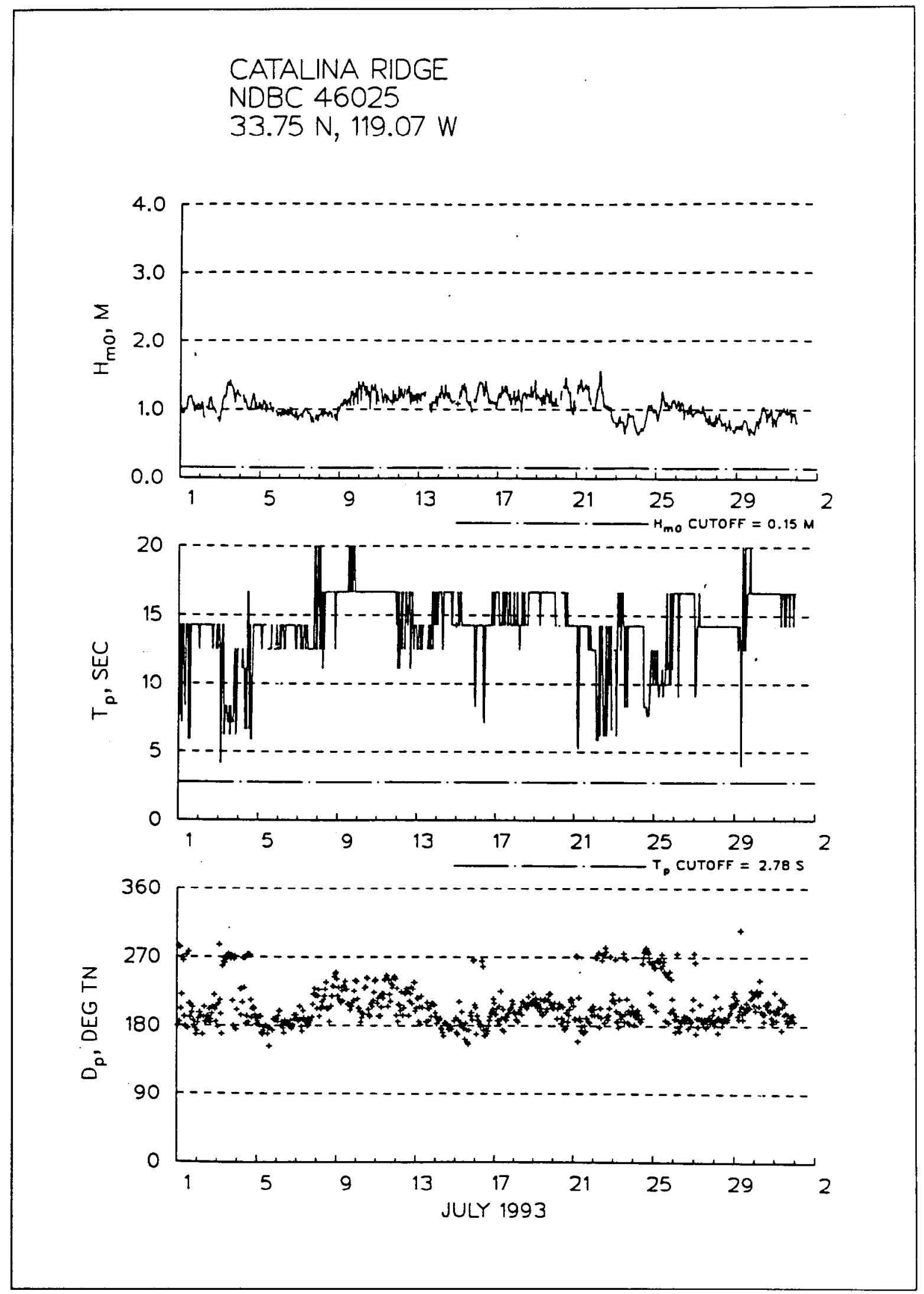

Figure L12. Catalina Ridge (NDBC 46025), July 1993 
CATALINA RIDGE

NDBC 46025

$33.75 \mathrm{~N}, 119.07 \mathrm{~W}$
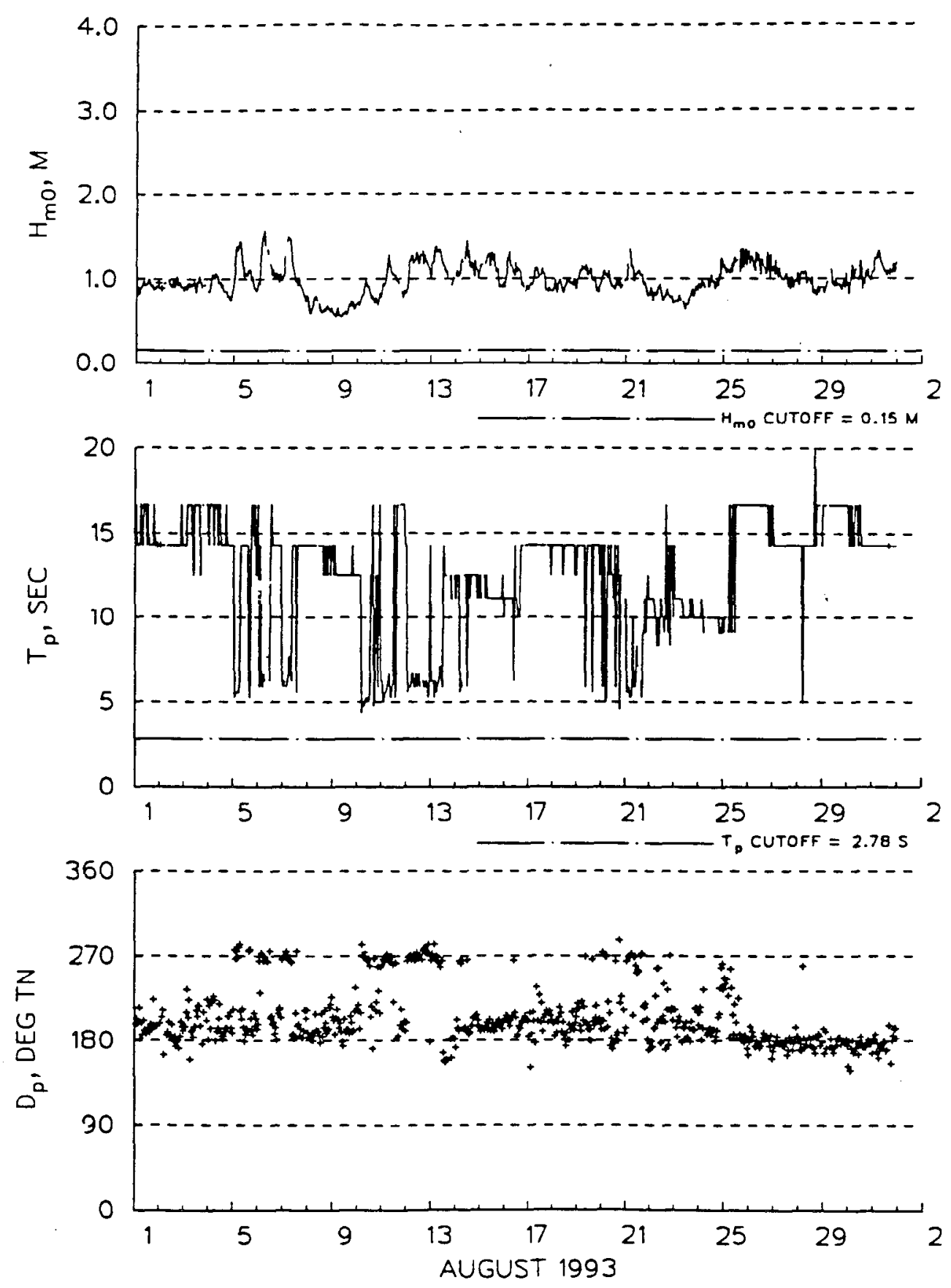

Figure L13. Catalina Ridge (NDBC 46025), August 1993 
CATALINA RIDGE

NDBC 46025

$33.75 \mathrm{~N}, 119.07 \mathrm{~W}$
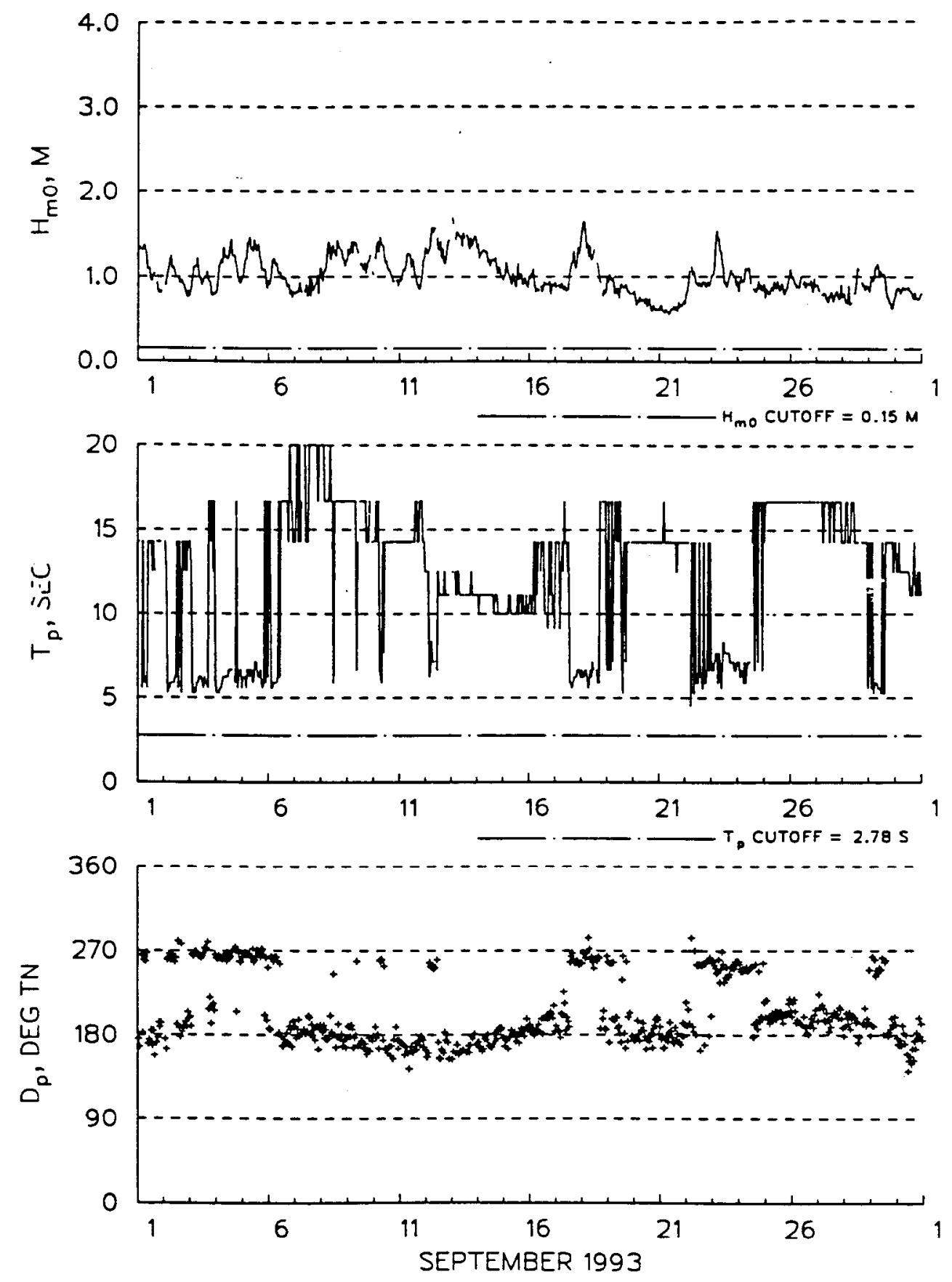

Figure L14. Catalina Ridge (NDBC 46025), September 1993 


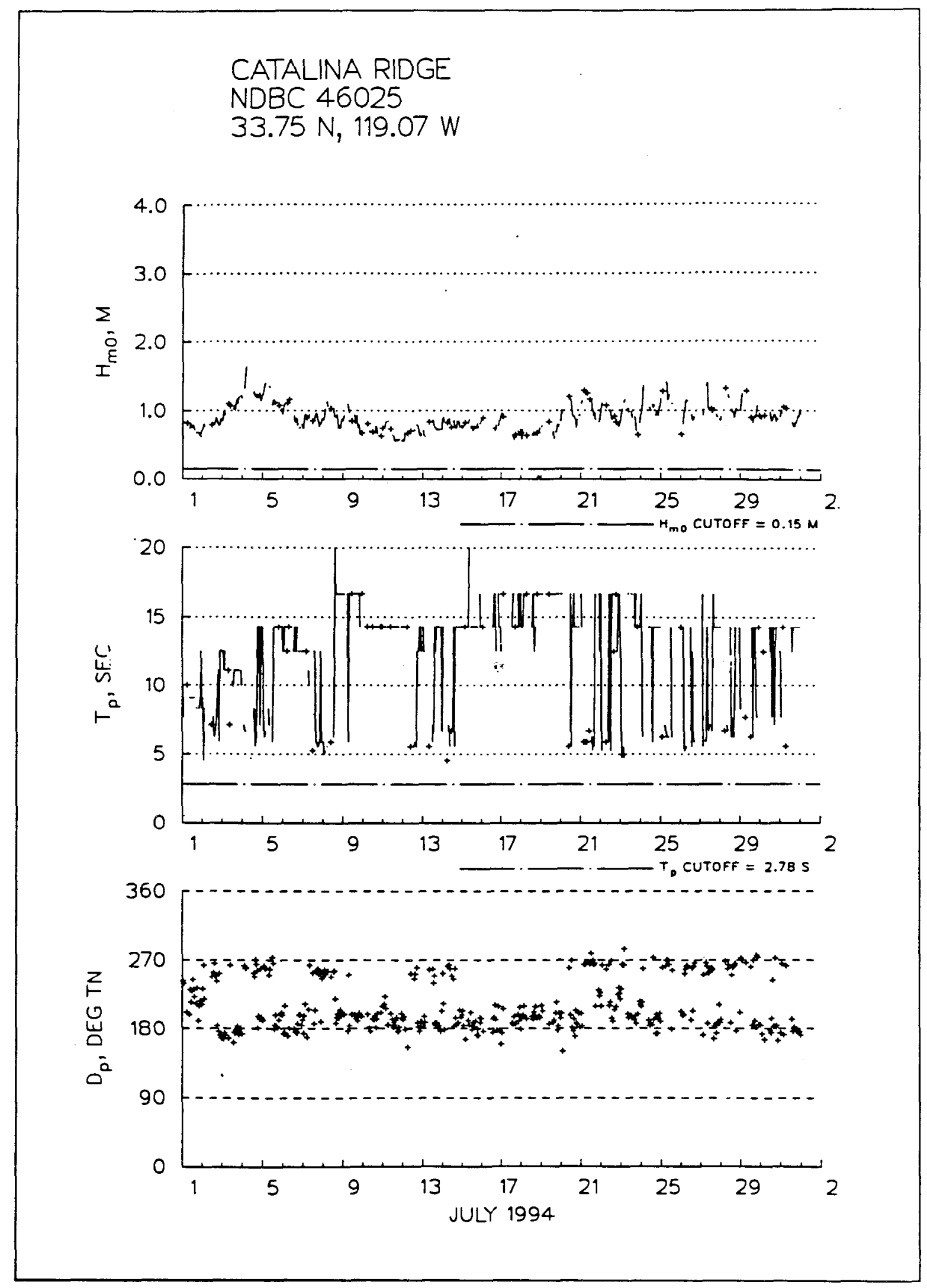

Figure L15. Catalina Ridge (NDBC 46025), July 1994 


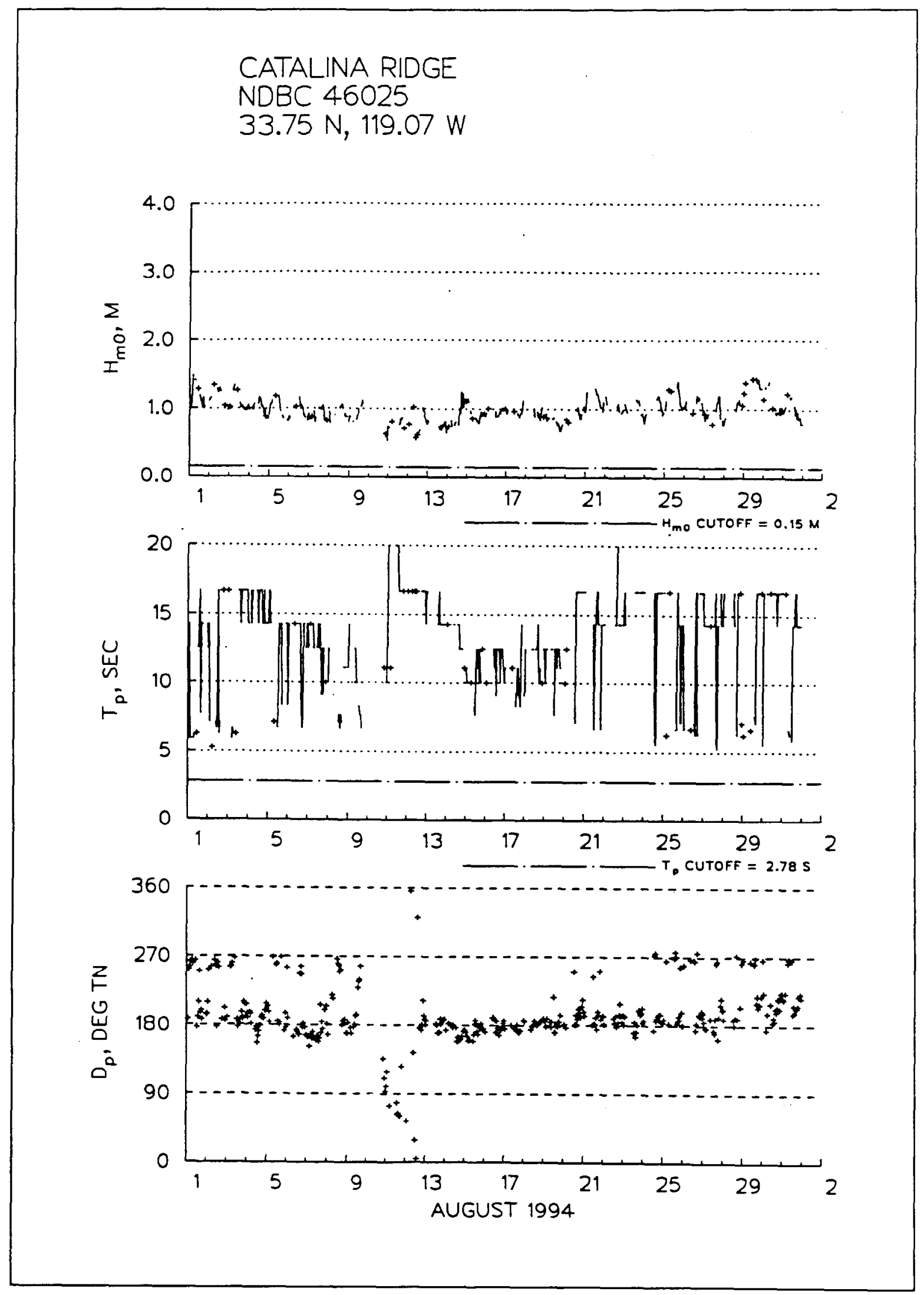

Figure L16. Catalina Ridge (NDBC 46025), August 1994 
CATALINA RIDGE

NDBC 46025

$33.75 \mathrm{~N}, 119.07 \mathrm{~W}$
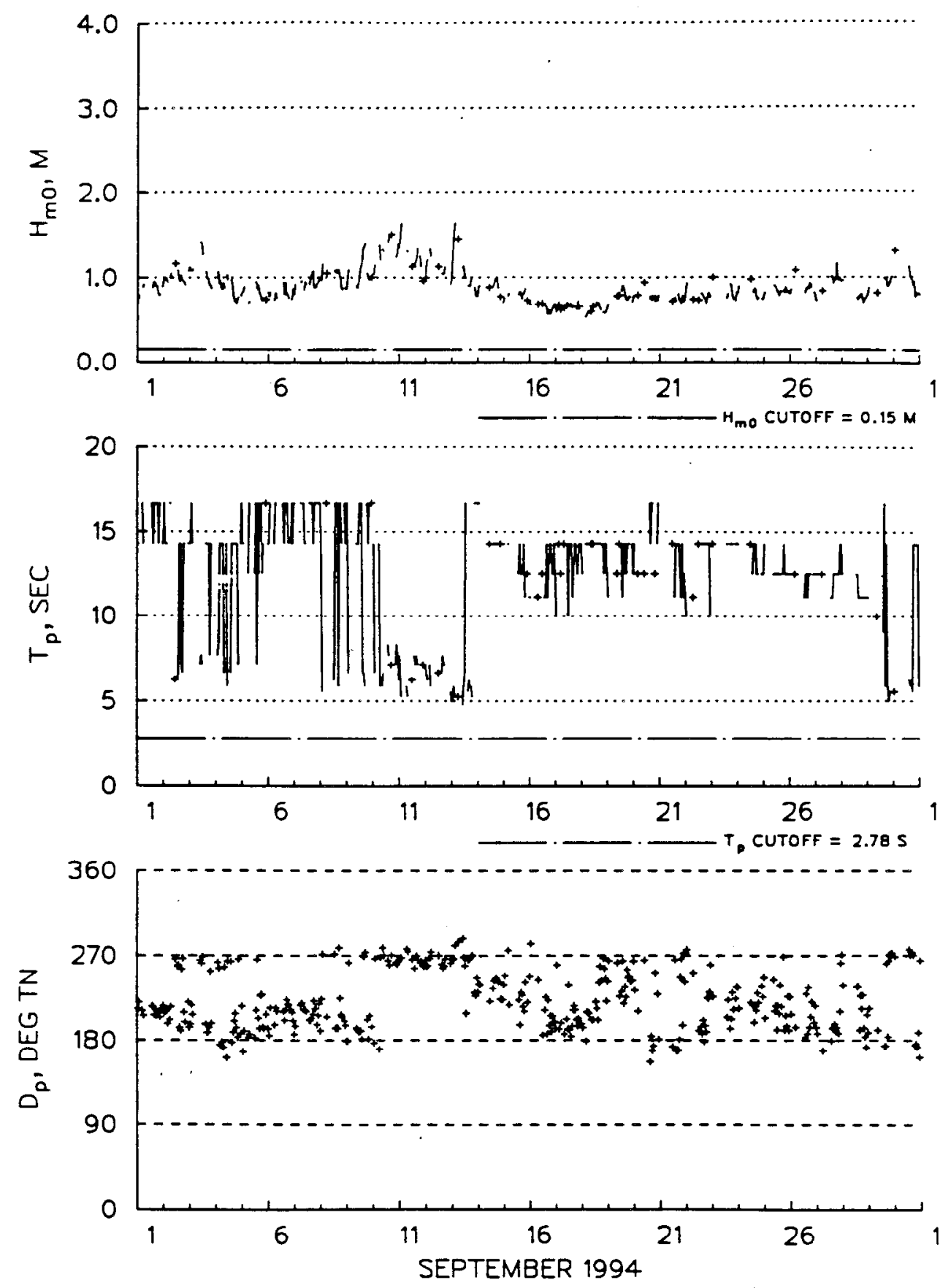

Figure L17. Catalina Ridge (NDBC 46025), September 1994 


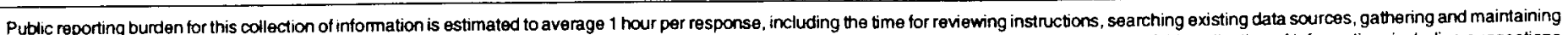

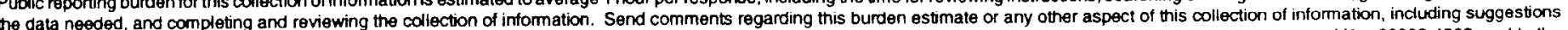

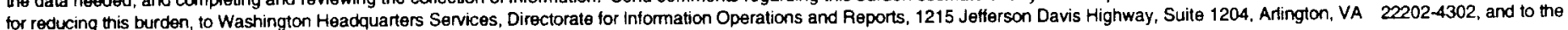
Otfice of Management and Budget, Paperwork Reduction Project (0704-0188). Washington, DC 20503.

\begin{tabular}{|l|l|l}
\hline 1. AGENCY USE ONLY (Leave blank) & $\begin{array}{l}\text { 2. } \begin{array}{l}\text { REPORT DATE } \\
\text { February 1996 }\end{array} \\
\text { Feb }\end{array}$ & $\begin{array}{l}\text { REPORT TYPE AND DATES COVERED } \\
\text { Final report }\end{array}$ \\
\hline
\end{tabular}

4. TITLE AND SUBTITLE

5. FUNDING NUMBERS

Redondo Beach, California, 1992-1994 Wave Data

6. AUTHOR(S)

Margaret A. Sabol

7. PERFORMING ORGANIZATION NAME(S) AND ADDRESS(ES)

U.S. Army Engineer Waterways Experiment Station

3909 Halls Ferry Road, Vicksburg, MS 39180-6199

8. PERFORMING ORGANIZATION REPORT NUMBER

Technical Report CERC-96-4

9. SPONSORINGMONITORING AGENCY NAME(S) AND ADDRESS(ES)

U.S. Army Corps of Engineers

10. SPONSORING/MONITORING

Washington, DC 20314-1000

AGENCY REPORT NUMBER

11. SUPPLEMENTARY NOTES

Available from National Technical Information Service, 5285 Port Royal Road, Springfield, VA 22161.

\section{DISTRIBUTIONAVAILABIUTY STATEMENT}

Approved for public release; distribution is unlimited.

12b. DISTRIBUTION CODE

\section{ABSTRACT (Maximum 200 words)}

This report summarizes field wave data acquired at Redondo Beach breakwater, CA, during a 2-year period beginning October 1992 and ending in June 1994. The purpose of this study was to provide actual field data to evaluate output from a numerical model which predicts wave propagating through a coastal region of irregular bathymetry. This report contains brief descriptions of the monitoring effort and equipment and provides collected wave information in graphic and tabular form. Statistical analysis of wave data will be provided in a future report.

14. SUBJECT TERMS

RCPWAVE

Redondo Beach breakwater

15. NUMBER OF PAGES

140

Wave data

16. PRICE CODE

Wave gages

17. SECURITY CLASSIFICATION OF REPORT

UNCLASSIFIED
18. SECURITY CLASSIFICATION OF THIS PAGE

UNCLASSIFIED
19.

SECURITY CLASSIFICATION OF ABSTRACT 